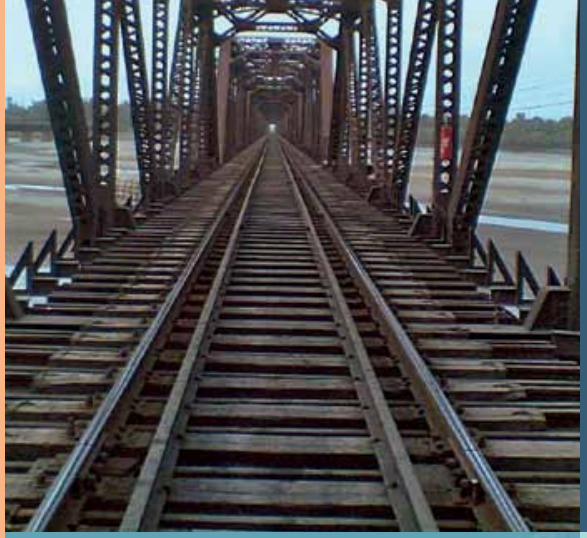

Gintautas BUREIKA

Maria BOILE

Christos PYRGIDIS

Annie KORTSARI

Natalia IVANOVA

Tamila TITOVA

Sergey TSYKHMISTRO

\title{
CONSOLIDATION
}

OF TECHNICAL,

SAFETY AND

HUMAN

RESOURCES

IN EURASIAN

RAILWAY

TRANSPORT

CORRIDORS

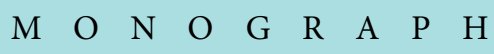


CONSOLIDATION OF TECHNICAL, SAFETY AND HUMAN RESOURCES IN EURASIAN RAILWAY TRANSPORT CORRIDORS 

GINTAUTAS BUREIKA

MARIA BOILE

CHRISTOS PYRGIDIS

ANNIE KORTSARI

NATALIA IVANOVA

TAMILA TITOVA

SERGEY TSYKHMISTRO

\section{CONSOLIDATION OF \\ TECHNICAL, SAFETY AND \\ HUMAN RESOURCES IN \\ EURASIAN RAILWAY \\ TRANSPORT CORRIDORS}

Monograph 


\section{Reviewers:}

Prof Dr Hab Aleksander SŁADKOWSKI, Silesian University of Technology, Poland

Prof Dr Hab Valery SAMSONKIN, State Economy and Technology University, Ukraine

The publication of this Open Access book has been funded by the European Commission FP7 Post-Grant Open Access Pilot.

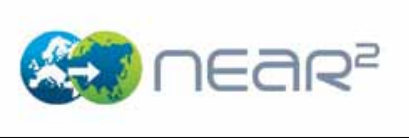

VGTU Press TECHNIKA book No 2375-M

http://leidykla.vgtu.lt

eISBN 978-609-457-978-3

doi: $10.20334 / 2375-\mathrm{M}$

This is an open-access monograph distributed under the terms of the Creative Commons Attribution-NonCommercial 4.0 (CC BY-NC 4.0) license, which permits unrestricted use, distribution, and reproduction in any medium, provided the original author and source are credited. The material cannot be used for commercial purposes.

(c) VGTU Press TECHNIKA, 2016 


\section{CONTENT}

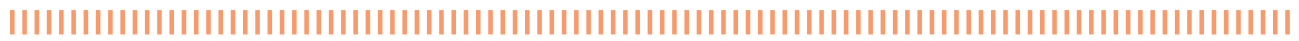

OVERALL SUMMARY................................ 10

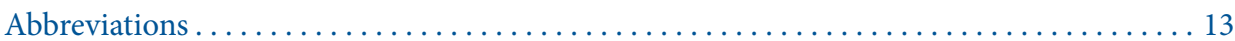

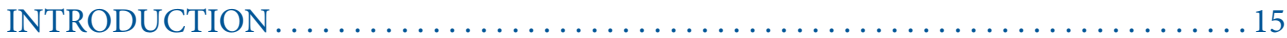

1. EURASIAN RAILWAYS NETWORK APPLICATION FIELD $\ldots \ldots \ldots \ldots \ldots \ldots \ldots \ldots 17$

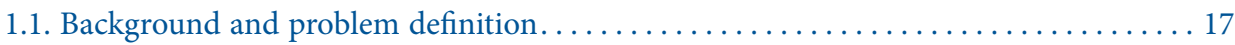

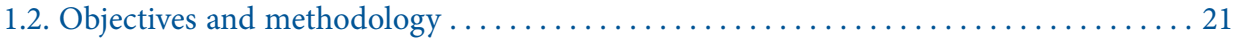

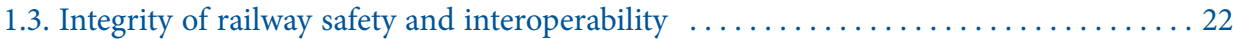

1.4. Essential requirements for safety and health in railway operation $\ldots \ldots \ldots \ldots \ldots \ldots 23$

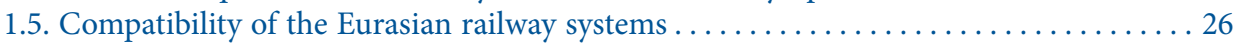

2. SELECTION AND ANALYSIS OF EUROPE-ASIA RAILWAY INFRASTRUCTURE . . 30

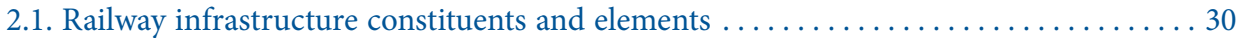

2.2. Analysis of the current situation of the railway infrastructure $\ldots \ldots \ldots \ldots \ldots \ldots \ldots 74$

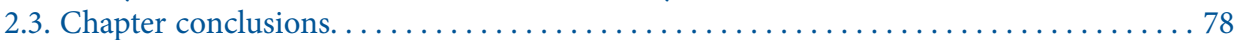

3. RAIL SAFETY AND SECURITY SYSTEMS OF EUROPEAN AND

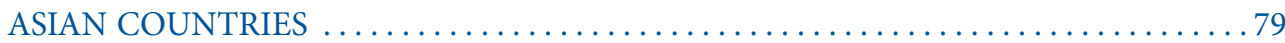

3.1. Comparison analysis of rail safety and security systems $\ldots \ldots \ldots \ldots \ldots \ldots \ldots \ldots$

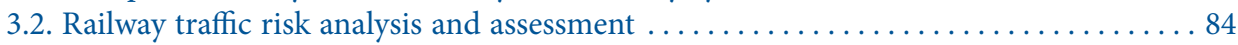

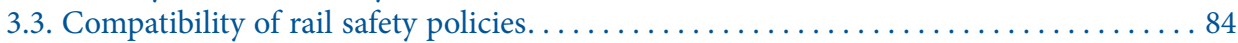

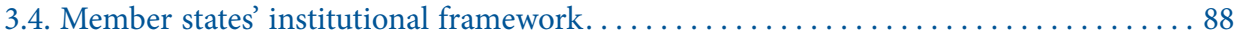

3.5. Regulations on Common Safety Methods ............................ 89

3.6. Applying Analytic Hierarchy Process to assess traffic safety risk of railway infrastructure.. 91

3.7. Demonstration of compliance with safety requirements.............. 106

4. SAFETY CERTIFICATION AND AUTHORISATION IN THE EURASIAN RAILWAYS. . 130

4.1. Certification problems and issues concerning the separation of

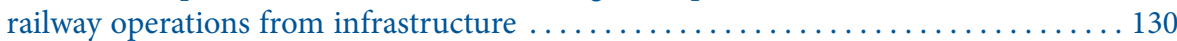

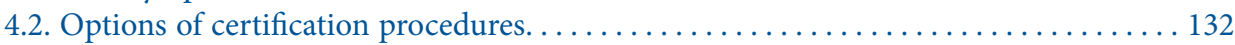

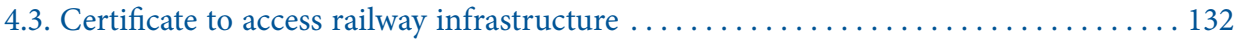

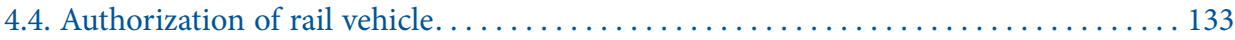




\section{TECHNICAL ASPECTS OF RAILWAY SAFETY AND INTEROPERABILITY IN} TRANS-EURASIAN LANDBRIDGE . . . . . . . . . . . . . . . . . . 135

5.1. Applied global intelligent systems for rail safety and security $\ldots \ldots \ldots \ldots \ldots \ldots \ldots$

5.2. Interfacing of rail vehicle devices with track-side train detection system . . . . . . 139

5.3. Reliability of wheel-rail impact measurement results by trackside control equipment 144

5.4. Hot axle-box/hot wheel detection systems $\ldots \ldots \ldots \ldots \ldots \ldots \ldots \ldots \ldots \ldots \ldots \ldots \ldots \ldots$

5.5. Features and tendencies of rail vehicle axle-box heating. . . . . . . . . . . 150

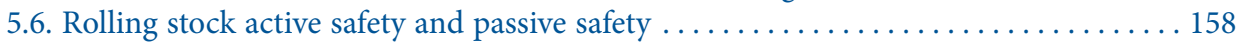

5.7. Investigation of wheelset slip and slide control problems of locomotives with AC

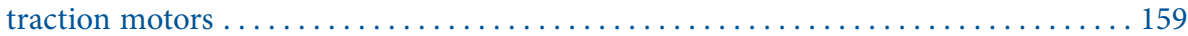

5.8. Research on diesel locomotives with DC traction motors wheelsets' slipping and sliding

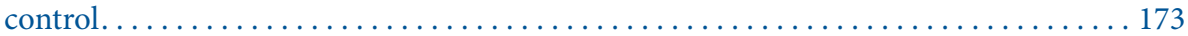

5.9. Rail vehicle passive safety . . . . . . . . . . . . . . . . . . . . 187

5.10. Railway technical and operational safety........................ 189

5.11. Rolling stock maintenance quality influence on railway safety $\ldots \ldots \ldots \ldots \ldots \ldots$

5.12. Investigation on improving diesel-electric locomotives' maintenance system. . . . . 193

5.13. Modelling of constant inter-failures of renewed

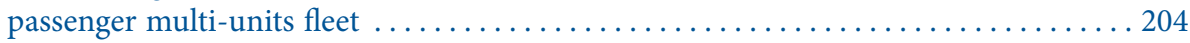

\section{EDUCATION AND TRAINING ISSUES FOR EURASIAN LAND BRIDGE SUPPORT}

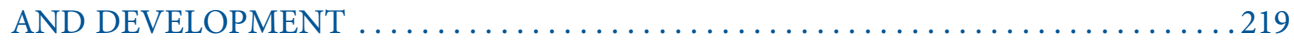

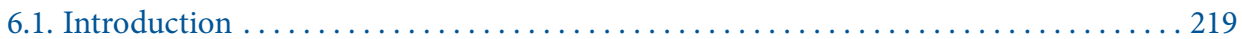

6.2. Comparison of rail education systems in countries

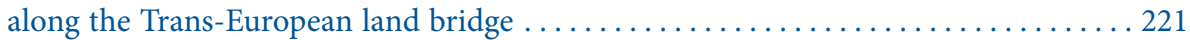

6.3. Harmonization of the rail educational standards in Europe. . . . . . . . . . . . . 225

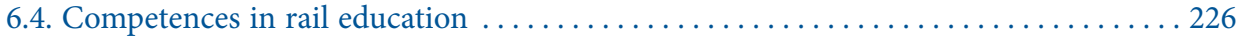

6.5. Gender issues . . . . . . . . . . . . . . . . . . . . . . . . . . . . . . 230

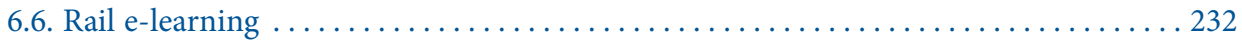

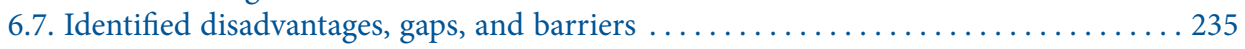

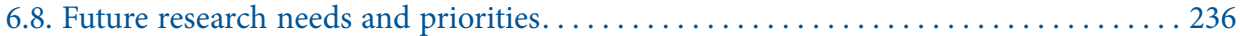

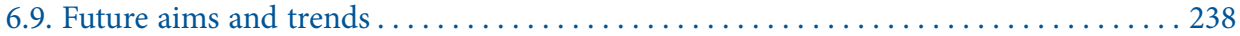

7. DISCUSSION AND OVERALL CONCLUDING REMARKS. . . . . . . . . . . 239

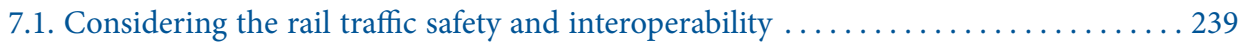

7.2. Considering the technical aspects and rolling stock maintenance $\ldots \ldots \ldots \ldots \ldots 242$

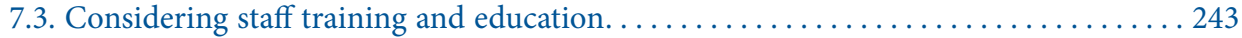

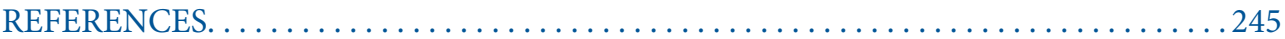




\section{LIST OF TABLES}

Table 1. Categories of conventional axle-load tracks based on the permitted load per axle of

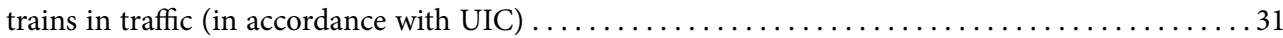

Table 2. Qualitative impact of axle load increase on the constituents and elements of a railway

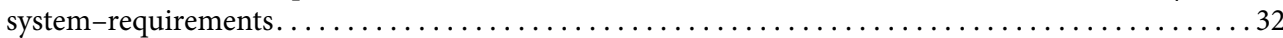

Table 3. Qualitative impact of train length and train weight increase to the constituents and

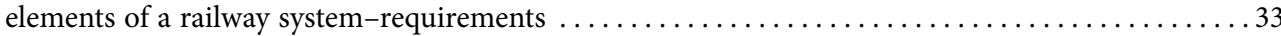

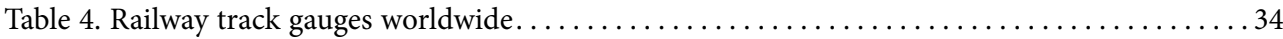

Table 5. Qualitative impact of train features on the constituents and elements of

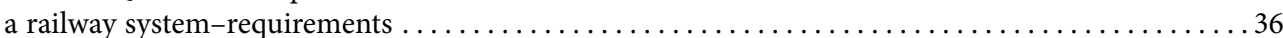

Table 6. Crossing countries of the Europe-Asia railway connection routes-Railway

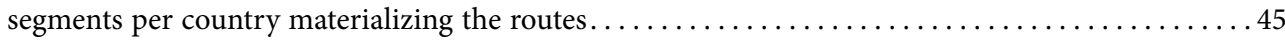

Table 7. Routes and stations with different types of traction within transport corridors .........59

Table 8. The comparison matrix of the factors increasing the threat "human injury" (threat T1) . . 101

Table 9. The weight values of the factors increasing the threat "human injury" (threat T1) $\ldots \ldots 102$

Table 10. The weight values of the factors increasing the threat "derailment" (threat T2) .......102

Table 11. The weight values of the factors increasing the threat "collision of rail vehicle" (threat T3) . 103

Table 12. Assessment of the weight of the threat "collision of rail vehicle" criteria on the railway lines.. 104

Table 13. Assessment of the threat "collision of rail vehicle" risk level $\ldots \ldots \ldots \ldots \ldots \ldots \ldots \ldots \ldots$

Table 14. Comparison of traffic risk levels of two Lithuanian Railway lines . . . . . . . . . . 105

Table 15. Mapping of safety methods to railway system life cycle stages (Impact Assessment 2013) . . 107

Table 16. Mapping of safety methods to risk assessment activities (Impact Assessment 2013) . . . 108

Table 17. PDCA for railway safety management (Tao Tang et al. 2009; El-Koursi et al. 2007) . ...110

Table 18. Comparison of railway safety policy systems in EU (Impact Assessment 2013) .......117

Table 19. Total number of national rules in EU countries (Impact Assessment 2013) . . . . . . . . 119

Table 20. Authorization categories used in the assessment (Impact Assessment 2013) . . . . . . 120

Table 21. Processing phases of harmonization, certification, and authorization in 2011-2025

(Impact Assessment 2013) . . . . . . . . . . . . . . . . . . . . . . . . . . . . . . . . 121

Table 22. Valid values of criteria that limit forces measured by TACE systems

(similar to ATLAS-LG) for detection of defective wheels in Eurasian railways . . . . . . . . . . . . 146

Table 23. Distribution of temperatures faulty axle-boxes of LG trains in 2011-2013 . . . . . . . 156

Table 24. The peculiarities of rail education systems in several countries located along

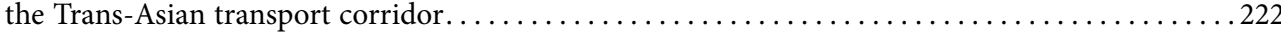

Table 25. Future research needs and priorities in relation to human resources $\ldots \ldots \ldots \ldots \ldots \ldots 236$ 


\section{LIST OF FIGURES}

Figure 1. Indicative existing alternative railway routes for the connection of

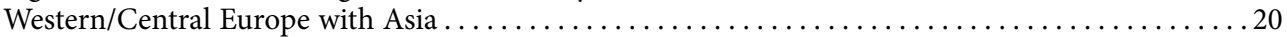

Figure 2. Design / Building / Development system / Use $\ldots \ldots \ldots \ldots \ldots \ldots \ldots \ldots \ldots \ldots \ldots \ldots$

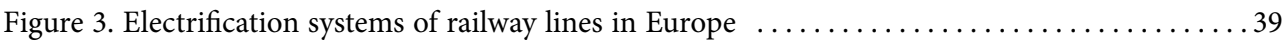

Figure 4. Electrification systems of railway lines in Central Asia $\ldots \ldots \ldots \ldots \ldots \ldots \ldots \ldots \ldots$

Figure 5. Electrification systems of railway lines in Central and East Asia $\ldots \ldots \ldots \ldots \ldots \ldots \ldots 41$

Figure 6. Initial analysis of significant change (El-Koursi et al. 2006) ................... 89

Figure 7. Risk assessment criteria of technical system approach (El-Koursi et al. 2006)..........90

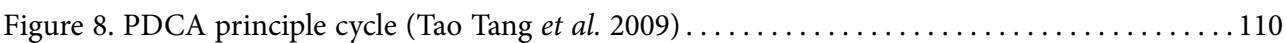

Figure 9. Trackside ERTMS contract in per cent by world-wide regions................. 140

Figure 10. Hot axle-box detection systems in Europe Railways (Eisenbrand 2011) . .......... 149

Figure 11. Principle scheme of hot box detection equipment $\ldots \ldots \ldots \ldots \ldots \ldots \ldots \ldots \ldots \ldots \ldots \ldots \ldots \ldots \ldots \ldots$

Figure 12. Dynamics of HABD halted LG trains with impermissibly hot rolling stock axle-boxes. . 153

Figure 13. Dynamics of the average idle time of LG trains halted by HABD in 2011-2013....... 154

Figure 14. Dynamics of LG trains halted in 2013 by danger levels . . . . . . . . . . . . . 154

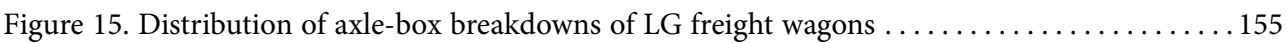

Figure 16. Locomotive adhesion coefficient dissipation dependence on locomotive speed in

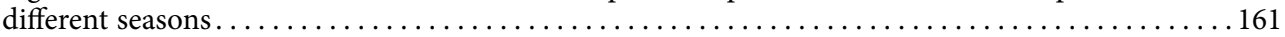

Figure 17. Diesel-electric powered locomotive characteristics in traction mode:. ............ 162

Figure 18. Wheel to rail force redistribution scheme (in traction mode) of

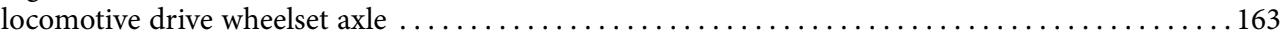

Figure 19. Different schemes of electric traction motor dislocation influence on

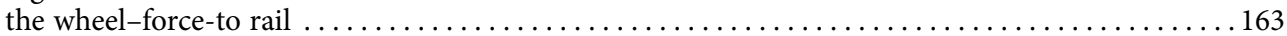

Figure 20. Redistribution scheme of locomotive bogie to rail force $\ldots \ldots \ldots \ldots \ldots \ldots \ldots \ldots \ldots$

Figure 21. Speed-torque characteristics of the $\mathrm{DC}$ and $\mathrm{AC}$ traction motor. $\ldots \ldots \ldots \ldots \ldots \ldots \ldots$

Figure 22. Circuit diagram of diesel-electric powered locomotive (AC/AC current system) drive, when one frequency converter is used to power three $\mathrm{AC}$ traction motors............... 167

Figure 23. The same type natural mechanical characteristics of asynchronous traction motors at

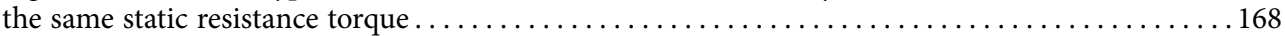

Figure 24. Control system of asynchronous engines with individual frequency converters . . . . 168

Figure 25. Artificial asynchronous mechanical characteristics of asynchronous motor when

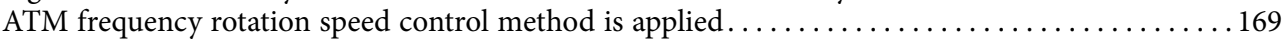

Figure 26. Circuit diagram of diesel-electric powered locomotive (AC/AC electric system) automatic wheelsets anti-slip and slide control system process parameters computer drive $\ldots \ldots 170$

Figure 27. Asynchronous traction motor with internal optical encoder: 1 is encoder ..........171

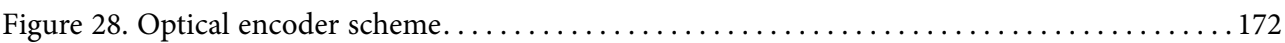

Figure 29. Distribution of normal and tangential stresses in the rail-wheel contact area in

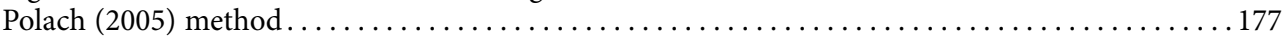


Figure 30. A circuit diagram of a series-wound DC traction motor.

Figure 31. A circuit diagram of a separately excited shunt-wound DC traction motor. ...

Figure 32. Speed-torque characteristics of the separately excited shunt-wound (1)

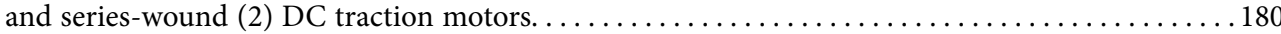

Figure 33. The effect of speed-torque characteristics on the tractive force of a locomotive,

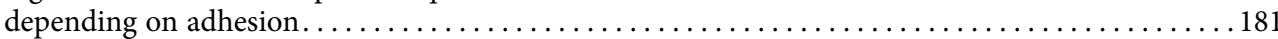

Figure 34. A scheme of a compensating system of the wheel-to-rail forces' redistribution in a locomotive operating in the traction mode

Figure 35. A circuit diagram of the relay wheelsets' slip and slide protection system in

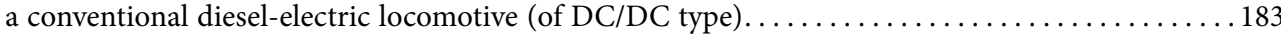

Figure 36. A circuit diagram of automatic control of wheelsets' slip and slide parameters in

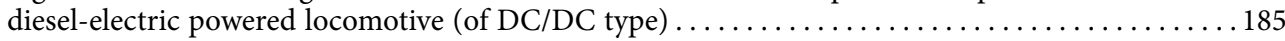

Figure 37. The curves demonstrating the 'spread' in DC traction motors' armature current in

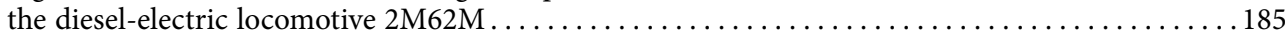

Figure 38. Load characteristics of a diesel-electric powered locomotive's (of DC/DC type)

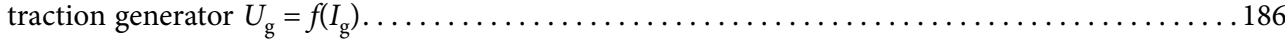

Figure 39. Maintenance Influence on the safety of freight wagon $[$ scheme] $\ldots \ldots \ldots \ldots \ldots \ldots 2$

Figure 40. Dependence of number of electric multi-unit one wagon failures on

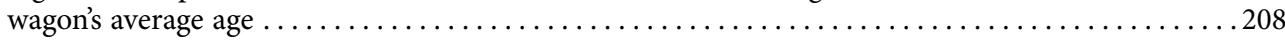

Figure 41. Decrease of the electric multi-unit fleet's average age during

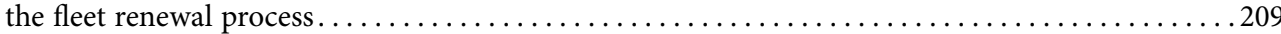

Figure 42. Dependence of the decrease in electric multi-unit failures on

the number of newly-acquired electric multi-unit wagons........................ 209

Figure 43. Failure intensity dependence on diesel multi-unit mileage $\ldots \ldots \ldots \ldots \ldots \ldots \ldots \ldots 211$

Figure 44. Failure intensity of diesel multi-unit fleet when the fleet is renewed according to

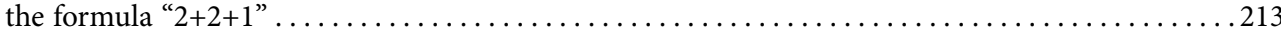

Figure 45. Approximation of diesel multi-unit failure intensity by continuous function $\ldots \ldots \ldots 214$

Figure 46. Approximation of diesel multi-unit failure data by splines of the third degree ......216

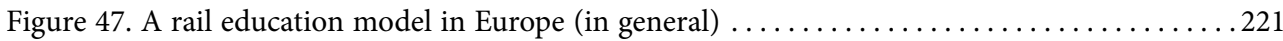

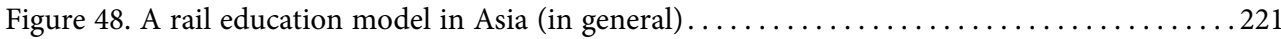

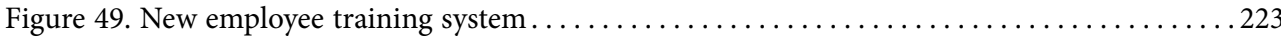

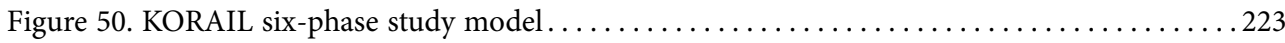

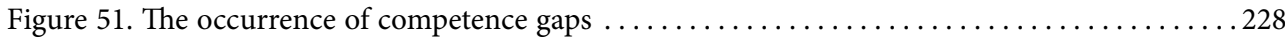

Figure 52. Graduates' competence gaps . . . . . . . . . . . . . . . . . . . . . . . . 229

Figure 53. The number of women in the Donetsk railways of SE "Ukrzaliznytsya" (Ukraine) ....230

Figure 54. The number of women in the JSC "RZhD" (Russia) . . . . . . . . . . . . . 230

Figure 55. Model of development rail e-learning courses.......................... 233

Figure 56. Web-technologies which may be used in the personnel qualification system for

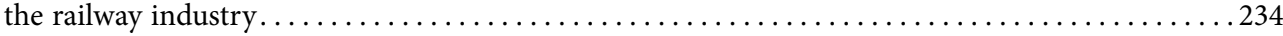

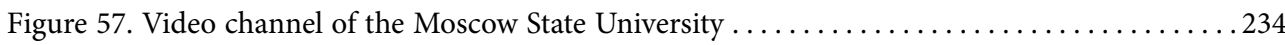

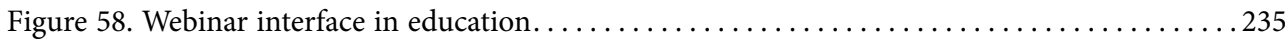




\section{OVERALL SUMMARY}

| | | | | | | | | | | | | | | | | | | | | | | | | | | | | | | | | | | | | | | | | | | | | | | | | | | | | | | | | | | | | | | | | | | | | | | | | | | | | | | | | | | | | | | | | | | | | | | | | | | | | | | | |

The investigation described in this monograph was conducted within the framework of the FP7 project NEAR ${ }^{2}$ - Network of European-Asian Rail Research Capacities from 2012 to 2014 . One of the main tasks of the $\mathrm{NEAR}^{2}$ project was the creation of 10 concept documents that would map the current situation along the Eurasian Railway land bridge in specific fields of expertise (based on the 10 poles of the European Rail Research Network of Excellence or EURNEX) and define future research needs based on identified gaps in technology and knowledge.

The monograph has been developed within the activities of three $\mathrm{NEAR}^{2}$ working groups (WG): WG6 "Safety and Security", WG8 "Infrastructure and Signalling," and WG10 "Training and Education". So, the content of the monograph is based on the abovementioned concept documents of the $\mathrm{NEAR}^{2}$ project. The project had multiple aims:

1. To define topics related to railway safety and security that affect the achievement of interoperability and rolling stock operation of the European-Asian railway corridors

2. To identify the problems, needs, gaps, and barriers that exist and degrade the regular rail movement of goods between Europe and Asia

3. To identify future research needs and priorities that will support the formulation of a research agenda for the Eurasian land bridge

The monograph is based on the outcomes of the discussions that took place within the ambit of the $\mathrm{NEAR}^{2}$ project. The monograph serves to bridge the gaps in knowledge and technology in order to improve technical interoperability, traffic safety regulations and risk assessment, and rolling stock maintenance system. It also seeks to analyse railway infrastructure more efficiently and to identify interoperability problems, staff training and educational issues in the railways of the Eurasian countries.

The national rail networks of various Eurasian countries evolved heterogeneously over the past century, and relevant national technical interoperability, safety regulations, and environment protection regulations were put in place, even before relevant international coordination existed. 
Three railway systems (geographical regions) were considered in this research work: the first, the railways of the countries in the European Union; the second, the Russian, Ukrainian, and Belarusian railways; and the third, the railways of Asian countries.

The monograph comprises seven chapters dealing with the particularities of rail safety regulation in different countries, technical aspects of safety and interoperability, infrastructure and signaling, rolling stock maintenance problems, locomotive slip and slide control, and training and education in Eurasian Railways.

\section{Scope of the monograph}

The present monograph aims at identifying and presenting a framework of actions that will allow the formulation of an appropriate scientific background and partnership that will, in turn, support the creation of a competitive Eurasian railway connection. Thus, the monograph focuses on the following:

1. Network application field, background and problem definition, objectives and study methodology, revealing of integrity of railway safety and interoperability; mapping of the current situation of infrastructure, and signaling; and staff training in Eurasian railways (Chapter 1).

2. Analysis and description of Eurasian railway infrastructure constituents and components: maximum axle load, maximum train length, track gauge, static and dynamic clearance, maximum speed both of passenger and freight trains, variety of traction and signaling systems, particularities of track maintenance (Chapter 2).

3. Comparison analysis of rail safety and security systems in European and Asian countries; problems of traffic safety risk assessment; compatibility of rail safety policies in different Eurasian countries, and harmonization progress of safety policy (Chapter 3).

4. Description of rail safety certification stages and processes in European Union countries; certification time and cost; characterization of certification procedure; single rail vehicle certificate; description of certificate to access railway infrastructure; the authorization of rail rolling stock (Chapter 4).

5. Explanation of technical aspects of railway safety in the Trans-Eurasian landbridge: progress of applying global intelligent systems; rolling stock devices in connection with the trackside system; rolling stock active and passive safety requirements and assessment; rolling stock maintenance quality impact on rail safety; research on locomotive driving wheel slip and slide control systems; modeling of inter-failures of renewed rail vehicle fleet and improvement of locomotive maintenance system (Chapter 5).

6. Railway human resources, training and education issues; verifying the necessity to create the integrated/ harmonized rail education and training system in the 
Eurasian space based on international experiences; the rail educational standards, knowledge management tools and principles, e-leaning practices (Chapter 6).

7. Overall concluding remarks: identification of future research needs and priorities that will support the formulation of a relevant research agenda for the Eurasian land bridge; identification of common future research projects related to the main topics of the monograph, as well as to the combination of the interests of the Eurasian rail industry and undertakings (Chapter 7).

\section{ACKNOWLEDGEMENTS}

This scientific work has been supported by the FP7 program Project NEAR ${ }^{2} 2012-$ 2014 (grant agreement number: 314254A). The project coordinator was the Centre for Research and Technology Hellas (CERTH), Hellenic Institute of Transport (HIT). The Project Manager was Dr Maria Boile, and Associate Project Manager Ms. Annie Kortsari.

A significant part of the contributions included in the monograph came from the work undertaken by researchers and scientists from the following European and Asian institutions:

1. Association "EURNEX" e.V., the European Rail Research Network of Excellence: Prof. Dr. h. c. Wolfgang H. Steinicke, CEO and Secretary General of "EURNEX" in 2007-2015, now - Honorary Secretary General \& In-house Consultant at "EURNEX". Prof. Markus Hecht and Prof. El-Miloudi El-Koursi are members of "EURNEX" Standing Committee.

2. Centre for Research and Technology Hellas (CERTH): Ms. Maria Chatziathanasiou.

3. Tongji University (IRRT), China: Prof. Weida Xie and Prof. Han Bin, and Mr. Yingfei Tu.

4. Euro-India Research Centre (EIRC): Ms. Sourabha Rani Theophilus, Mr. Karthik Kumar, and Ms. Sandhya Venkatesh.

5. Czech Technical University in Prague (CVUT): Mr Vít Malinovský.

6. Moscow State University of Railway Engineering (MIIT): Prof. Vladimir Solovyev, Prof. Valery Kruglov, and Assoc. Prof. Nikolay Putsko.

7. Donetsk Railway Transport Institute of Ukrainian State Academy of Railway Transport (DRTI): Prof. Cheptsov Mikhailo.

8. French Institute of Science and Technology for Transport, Development and Networks (IFSTTAR): Prof. El-Miloudi El-Koursi and Mr. Eric Bessmann. 


\section{ABBREVIATIONS}

AC/AC Alternative current and alternative current system

AC/DC Alternative current and direct current system

AHP Analytic Hierarchy Process

ATM Asynchronous Traction Motors

ATP Automatic Train Protection

CD Concept Document

COTIF Convention concerning International Carriage by Rail

CSI Common Safety Indicators

CSM Common Safety Methods

CST Common Safety Targets

DC/DC Direct current and direct current system

EATL Euro-Asian Transport Links

ERA Europe Railway Agency

ERTMS European Rail Traffic Management System

ETCS European Train Control System

EU Europe Union

EURNEX European Rail Research Network of Excellence

HABD Hot Axle-Box Detection

HWD Hot Wheel Detection

FAI First Article Inspection

GOST Russian State Standard

IEC International Electrotechnical Commission

IM Infrastructure Manager

IRIS International Railway Industry Standard

ISO International Organization for Standardization

JSC Joint Stock Company

ISO International Organization for Standardization

LG JSC "Lithuanian Railways"

LCC Life Cycle Cost

NSA National Safety Agency

OSJD Organization for Cooperation of Railways

PDCA Plan, Do, Check and Act (Deming process)

RAC Risk Acceptance Criteria

RAC-TS Risk Acceptance Criteria of Technical System

RAMS Reliability, Availability, Maintenance, Safety

RU Railway Undertaking 
RZhD Russian Railways

SE State Enterprise

SPAD Signal Passing as Danger

SMARTrail Sustainable Maintenance and Analysis of Rail Transport Infrastructure

SMS Safety Management System

TACE Trackside automated control equipment

TAR Trans-Asian Railway

TSI Technical Specifications for Interoperability

TRACECA Transport Corridor Europe-Caucasus-Asia

UIC International Union of Railways

UN United Nations

WILD Wheel impact load detector 


\section{INTRODUCTION}

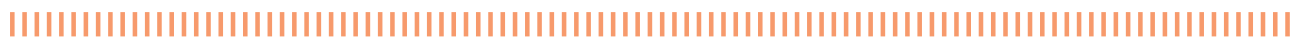

The rapid development of Asian economies, particularly of China, India, and Kazakhstan, has dramatically increased the trade volumes between Europe and Asia, with the largest trading partners of Europe actually being located in Asia (Migliardi et al. 2012). Nowadays, the most significant trade loads are being transported between the two continents using maritime routes.

Rail transport, using both the existing and new land routes for the Trans-Eurasian land bridge presents a viable alternative to the maritime routes, and is gaining significant momentum. Due to the origins and current nature of this rail land bridge, numerous issues need to be resolved to bring the infrastructure, services, and operations to a modern state. Furthermore, to build the capacity to fully exploit the system's potential adaptation of new technologies, interoperability solutions and optimized safety operations should be considered. In order to support this objective, NEAR ${ }^{2}$ proposes the creation of a rail research network along the Trans-Eurasian land bridge, exploiting the structure and leveraging the achievements of the existing European Rail Research Network of Excellence (EURNEX), thus engaging all the existing research centers in a continuous and fruitful international cooperation.

The monograph contributes to the general objective of improving the competitiveness of the railway sector vis-à-vis other transport modes, especially in the Eurasian land bridge context. Three main factors that ensure the attractiveness and reliability of any mode of transport are:

1. Transportation speed (short duration) and punctuality/ reliability

2. Safety and security both of passengers and freight

3. Reasonable cost of service

One of the main tasks of this monograph is to map all the technological issues related to the achievement of interoperability along the EU-Asia railway network. The gaps in the existing knowledge in terms of barriers and potential solutions are also investigated, thus resulting in the identification of research needs and priorities. These issues are rail traffic safety, railway technical interoperability, compatibility of infrastructure, rolling stock maintenance system and technical conditions of rail vehicles; human resources, training and education. 
Each chapter of the monograph identifies and analyses the relevant points in each topic of interest, while a more in-depth analysis of the most important ones follows. The goal of this analysis is the identification of needs, barriers, and urgent research recommendations in relation to the Eurasian railway corridor.

\section{Sustainability and integrity of Eurasian railways}

The efficiency of an "operational" Europe-Asia railway link, like any railway system, is ensured through the rational operation of three components: the railway infrastructure, the rolling stock, and the transportation process. The rapid development of railway systems requires that the issues of safety and reliability of passengers and freight, and increased costs and reliability of rolling stock maintenance system be looked into. Therefore, the development of new techniques and approaches to improve safety and reliability, and reduce maintenance costs is needed. Along this line, another issue that merits attention is the development of real-time detection techniques (trackside equipment) and the establishment of intelligent monitoring systems. Generally, a smart monitoring system is also necessary to find, prevent, and manage railway traffic risks.

The consolidation of the Eurasian railways is necessary to define the minimum requirements for maximum rolling stock safety and to enable seamless transport flow on the both European and Asian railways. 


\section{EURASIAN RAILWAYS 1 NETWORK APPLICATION FIELD}

\subsection{Background and problem definition}

The efficiency of the Europe-Asia railway links, like any railway system, depends on many factors including environmental safety and energy efficiency. UN support for the development of transport connections between Europe and Asia has a long history. The global project entitled "Capacity-building for Developing Interregional Land and Land-cum-sea Transport Linkages" carried out between 2003 and 2007 included a component focusing specifically on Euro-Asian transport links (EATL). It identified certain main EATL of international importance in order to connect the European and Asian networks, including nine rail routes. Among these routes there are seven routes that pass through the territory of Russia. It is therefore particularly important to know the current state and perspectives of development of infrastruture, referring to various technical aspects. Similar issues apply to other countries that are crossed by the rail lines considered within the context of the $\mathrm{NEAR}^{2}$ project; these are presented in the following sections.

In the context of the $\mathrm{NEAR}^{2}$ project, the network application field has been defined based on:

1. Existing alternative railway routes that connect Western/Central Europe to Asia and more specifically to Japan (via the Sea of Japan), China, and India.

2. Existing case studies of Europe-Asia cargo transportation by rail (RETRACK ... 2012; Emerson et al. 2009).

The indicative routes that have been selected for further analysis and examination are the following:

\section{A: Connection: Western Europe-Russian Far East-Japan}

A1: Via main Trans-Siberian railway network:

Poland-Belarus or Ukraine-Russia (Moscow-Novosibirsk-Irkutsk-Vladivostok or Nakhoka)-Japan (Sea of Japan)

Total length: Warsaw-Vladivostok: 11,000 km 
B: Connection: Western Europe-China via the Trans-Siberian route and its branches B1: Via branch of the Trans-Siberian railway network and the Manchurian route:

Poland-Belarus or Ukraine-Russia (Moscow-Novosibirsk-Karymskaya-Zabaykalsk)-China (Harbin-Beijing via Manchuria)

Total length: Warsaw-Beijing: 11,670 km

B2: Via branch of the Trans-Siberian railway network and the Trans Kazakh route:

Poland-Belarus or Ukraine-Russia (Moscow-Yekaterinburg-Kurgan)-Kazakhstan (Petrovavlosk-Astana-Dostyk)-China (Lanzhou-Zhengzhou-Beijing)

Total length: Warsaw-Beijing: 11,670 km

B3: Via branch of the Trans-Siberian railway network and the Mongolian route:

Poland-Belarus or Ukraine-Russia (Moscow-Novosibirsk-Ulan-Ude-Naushki)Mongolia (Zamyn Uud)-China (Beijing)

Total length: Warsaw-Beijing: 11,560 km

C: Connection: Western Europe-China via the TRACECA corridor (Silk Road)

C1: Via the TRACECA-Turkmenbashi rail route:

C1.1: Western Europe-Slovakia (Bratislava)-Hungary (Budapest)-Romania (Bucharest, Constanta) or Bulgaria (Varna)-Black Sea-Georgia (Poti-Gardabani)-Azerbaijan (Boyuk Kasik-Baku)-Caspian Sea-Turkmenistan (Turkmenabad)-Uzbekistan (Khodza Davlet-Keles)-Kazakhstan (Sary Agash-Almaty-Dostyk)-China (Lanzhou-Zhengzhou-Beijing)

Total length: Bratislava-Beijing: 10,090 km + (water route via Black sea $=1,270 \mathrm{~km}$ )

C1.2: Western Europe-Slovakia (Bratislava)-Hungary (Budapest)-Romania (Bucharest)-Bulgaria-Turkey (Edirne-Istanbul-Sive-Kars)-Armenia (Akhurgan-Ayrum) or Georgia-Azerbaijan (Boyuk Kasik-Baku)-Caspian Sea-Turkmenistan (Turkmenabad)Uzbekistan (Khodza Davlet-Keles)-Kazakhstan (Sary Agash-Almaty-Dostyk)-China (Lanzhou-Zhengzhou-Beijing)

Total length: Bratislava-Beijing: 12,170 km + (water route via Caspian Sea $=270 \mathrm{~km}$ )

C2: Via the TRACECA-Aktau route:

C2.1 (land detour of the Black Sea through Ukraine and Russia): Western EuropeSlovakia (Bratislava)-Ukraine (Chop-Fastov-Dnepropetrovsk)-Russia (Rostov)Azerbaijan (Yalama-Baku)-Caspian Sea-Turkmenistan (Turkmenabad)-Uzbekistan (Khodza Davlet-Keles)-Kazakhstan (Sary Agash-Almaty-Dostyk)-China (LanzhouZhengzhou-Beijing)

Total length: Bratislava-Beijing: 12,885 km

C2.2: In C1.2 the section Caspian Sea-Turkmenistan (Turkmenabad)-Uzbekistan (Khodza Davlet-Keles)-Kazakhstan (Sary Agash-Almaty-Dostyk) is replaced by the section Caspian Sea-Kazakhstan (Aktau-Makat-Kandagash-Sary Agash-Almaty-Dostyk)

Total length: Bratislava-Beijing: 12,710 km 


\section{D: Connection: Western Europe-China via the Central Corridor in Kazakhstan}

Western Europe-Poland-Belarus or Ukraine-Russia (Moscow-Aksaralskaya)-Kazakhstan (Ganushkino-Makat-Kandagash-Almaty-Dostyk)-China (Lanzhou-Zhengzhou-Beijing)

Total length: Warsaw-Beijing: 11,645 km

E: Connection: Western Europe-India via the Trans-Asian railway route

Western Europe-Slovakia (Bratislava)-Hungary-Bulgaria-Turkey-Iran-PakistanIndia (New Delhi)

Total length: Bratislava-New Delhi: 7,970 km

The above mentioned Trans-Eurasian railway routes are presented in Figure 1.

The countries involved in the creation of the Eurasian railway corridors are responsible for ensuring compliance with the safety, health, and consumer protection rules applying to the railway networks in general during the design, construction, putting into service and operation of those railways. There are major differences between the national regulations and the internal rules and technical specifications which the railways apply, since they incorporate techniques that are specific to the national industries and prescribe specific dimensions, devices, and special characteristics. This situation prevents trains from being able to run without any hindrance throughout the EU railway network as well as in the Asian countries.

Over the years, this situation has created very close links between the national railway industries and the national railways, to the detriment of the genuine opening up of markets. In order to enhance their competitiveness at the global level, these industries require an open, competitive European market (TREN/R1/350-2008 ... 2010). It is therefore appropriate to define basic essential requirements for the whole of the European Community which will apply to its rail system as well.

Over the years, national rail networks have developed different technical specifications for infrastructure and rolling stock ${ }^{1}$, making it difficult and costly to run a train from one country to another. Also, different national rules-often overly complicated and not transparent-act as major obstacles for new railway companies looking to establish themselves in the market, or indeed for any company wanting to use rail infrastructure in different countries.

It must be stressed that, following the introduction of the respective railway packages, the level of railway safety (measured by indicators like the number of accidents and fatalities) has gradually increased.

1 Resulting, inter alia, in different gauge widths, electrification standards, and safety and signaling systems 


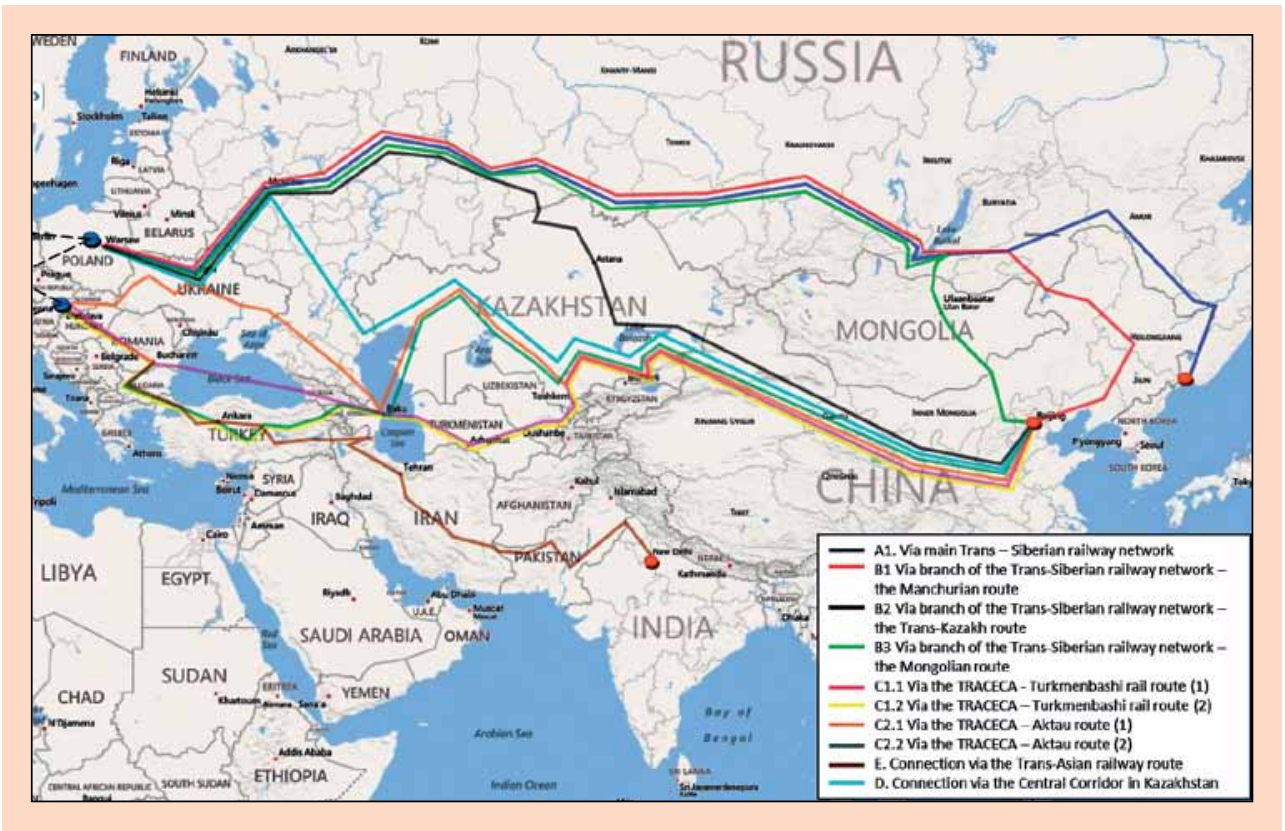

Figure 1. Indicative existing alternative railway routes for the connection of Western/ Central Europe with Asia

(source: Project NEAR ${ }^{2}$. Deliverable D3.8 Concept Document "Infrastructure and Signalling")

However, the EU Commission has received frequent complaints that the system of the railway authorities described above, although intending to address the persisting technical differences between national railway systems, incorporates different barriers that contribute, among other reasons, to the low degree of efficiency and competitiveness of the rail sector as illustrated by the problem tree of the fourth railway package. While in some member states the national authorities generally function efficiently, in others, the procedures they manage are long and costly; this is partly linked to their inadequate resources. At the same time, the interoperability and safety requirements, which in principle should have been aligned to common EU standards, still diverge significantly at the national level. The latter obstacles hamper, in particular, the processes leading to the delivery by the National Safety Authorities (NSAs) of the safety certificates and the vehicle authorizations.

The creation of an integrated European railway area, which quickened with the adoption of the second railway package in 2004, called for harmonized safety rules and improved "interoperability" ${ }^{2}$ - or technical compatibility - of infrastructure, rolling

2 Interoperability is the essential ability of a rail system to allow the safe and uninterrupted movement of trains which accomplish the required levels of performance for these lines. 
stock (rail vehicle), signaling, and other parts of the rail system, as well as less complex procedures for approving rolling stock for use across the European rail network. Specific EU legislation exists to promote a consistent approach to interoperability and safety and to overcome national differences.

The main legislative act in force in the field of safety is the Railway Safety Directive and in the field of interoperability, a recast of the Interoperability Directive.

The Safety Directive applies to the railway system of member states and covers safety requirements for the system as a whole, including infrastructure and traffic management, and the interaction between railway undertakings and infrastructure managers.

In this respect, the Safety Directive focuses on four major aspects, as follows:

3. Setting up, in each member state, of an authority responsible for supervizing safety

4. Safety certificates delivered in member states that are necessary for railway undertakings to be granted access to railway infrastructure

5. Establishment of common safety indicators (CSIs) in order to assess that the system complies with the common safety targets (CSTs) and to facilitate the monitoring of railway safety performance

6. Definition of common rules for safety investigations

The Interoperability Directive aims at accelerating integration of the EU rail network through increased technical harmonization, guaranteeing a high level of safety (Proposal for a Directive 2013). It establishes conditions to be fulfilled to achieve interoperability within the EU rail system at the design, construction, placing into service, upgrading, renewal, and operation or maintenance stages. The gradual implementation of interoperability of the rail system is pursued through the harmonization of technical standards.

Thus this Interoperability Directive covers:

1) essential requirements with regard to safety, reliability, human health, environmental protection, and technical compatibility of the system;

2) the technical specifications for interoperability (TSIs) adopted for each subsystem or part of a subsystem pursuant to this directive;

3 ) the corresponding European specifications.

\subsection{Objectives and methodology}

The purpose of the research is to develop the sustainability of the Eurasian land bridge railways and improved access to the market for rail transport services. In the context described above, the European Commission sought the commissioning of a project on EU member states and third countries' national civil liability regimes in relation to rail accidents occurring in the course of an international service between railway 
undertakings (RUs) and infrastructure managers (IMs) insofar as they may present a barrier to the internal market.

The EU legislation on safety contains a definition of rail accidents. Article No3, (k) of Directive 2004/49/EC defines an accident as "an unwanted or unintended sudden event or a specific chain of such events which have harmful consequences; accidents are divided into the following categories: collisions, derailments, level-crossing accidents, accidents to persons caused by rolling stock in motion, fires, and others." ${ }^{3}$

This monograph deals with the progress of railways interoperability, technical safety aspects, differences of various infrastructures, and development of human resources (high qualification employees) in Eurasian railways. A number of questions concerning the progress of interoperability were discussed with the authorities, infrastructure managers, railway undertakings, and the supply industry representatives.

The information needed for this monograph was basically gathered by the following means.

1. Consultations concerning the study with the following stakeholders:

1) European Commission (EC) regulation;

2) European Railway Agency (ERA) activity;

3) representatives of several countries-NEAR ${ }^{2}$ project partners and the third part;

4) train operators;

5) infrastructure managers; and

6) the railway industry.

2. Online research (projects, studies, dissertations, publications, etc.).

Following these consultations and online research, the monograph team carried out its analysis. This involved discussions with EC and ERA officials.

\subsection{Integrity of railway safety and interoperability}

The different initiatives vis-à-vis interoperability are divided into three main domains (Impact Assessment ... 2013):

I. Infrastructure governance: This involves ensuring that the infrastructure manager consistently performs a set of functions that optimise the use of infrastructure capacity, and that the organization of the IM guarantees non-discriminatory and safe access to the infrastructure and rail-related services.

\footnotetext{
3 Directive 2004/49/EC of the European Parliament and of the Council of 29 April 2004 on safety on the Community's railways and amending Council Directive 95/18/EC on the licensing of railway undertakings and Directive 2001/14/EC on the allocation of railway infrastructure capacity and the levying of charges for the use of railway infrastructure and safety certification (Railway Safety Directive), [2004] OJ L 164/44 and [2004] OJ L 220/16, as last amended by Directive 2008/110/EC [2008] OJ L 345/62.
} 
II. Interoperability and safety: This involves removing the remaining administrative and technical barriers, in particular, by establishing a common approach to safety and interoperability rules to decrease administrative costs, to accelerate procedures, to increase economies of scale for RUs, and to avoid disguised discrimination.

III. The interoperability and safety pillar: This involves assessing several 'institutional' options at the level of interaction between ERA and national authorities with the aim to: (a) enhance the effectiveness and efficiency of safety certification and rolling stock authorization processes, and (b) reduce the complexity caused by excessive national railway rules. As a separate option, a set of additional horizontal measures would be considered, which on their own could achieve the mentioned objectives, but could also be applied on top of the institutional options to reinforce the overall impact of reduced administrative costs or less fragmented markets.

Several key problems of the railway industry are associated with the progress of interoperability, resulting, inter alia, in different gauge widths, electrification standards, and safety and signaling systems. Interoperability is the essential ability of a rail system to allow the safe and uninterrupted movement of trains which accomplish the required levels of performance for Eurasian railway lines.

This ability rests on all the regulatory, technical, and operational conditions, which must be met in order to satisfy certain essential requirements.

These essential requirements include:

1. safety and interoperability;

2. reliability and availability;

3. health;

4. environment; and

5. technical compatibility

\subsection{Essential requirements for safety and health in railway operation}

\section{General requirements}

1.1. The design, construction or assembly, maintenance and monitoring of safetycritical components, and more particularly of the components involved in train movements, must be such as to guarantee safety at the level corresponding to the aims laid down for the network, including those for specific degraded situations.

1.2. The parameters involved in the wheel-rail contact must meet the stability requirements needed in order to guarantee safe movement at the maximum authorized 
speed. The parameters of the brake equipment must guarantee that it is possible to stop within a given brake distance at the maximum authorized speed.

1.3. The components used must withstand any normal or exceptional stresses that have been specified during their period in service. The safety repercussions of any accidental failures must be limited by appropriate means.

1.4. The design of fixed installations and rolling stock and the choice of the materials used must be aimed at limiting the generation, propagation, and effects of fire and smoke in the event of a fire.

1.5. Any devices intended to be handled by users must be so designed so as not to impair the safe operation of the devices or the health and safety of the users if used in a foreseeable manner, even if not in accordance with the posted instructions.

2. Health

2.1. Materials likely to constitute a health hazard to those having access to them, by virtue of the way they are used, must not be used in trains and railway infrastructures.

2.2. Those materials must be selected, deployed, and used in such a way that restricts the emission of harmful and dangerous fumes or gases, particularly in the event of a fire.

The initial measures taken in the rail sector were Directive 96/48/EC on the interoperability of the trans-European high-speed rail system, and Directive 2001/16/EC on the interoperability of the trans-European conventional rail system, amended by Directive 2004/50/EC. These directives were recast by Directive 2008/57/EC on the interoperability of the rail system within the community, which is currently in force as amended by Directive 2009/131/EC and Directive 2011/18/EU.

The interoperability directives put into place a system for conformity assessment against the TSIs, the placing into service of subsystems, and the placing of interoperability constituents in the market. The roles of the key actors and bodies-such as notified bodies, contracting entities, and supervisory authorities-are established. Further, the directives mandate the development of TSIs which establish the technical interoperability requirements that subsystems and interoperability constituents shall meet. It is expected that these measures will gradually create an open market for rail products and systems, create true operational rail interoperability at a European level, and reduce the high costs and burdens currently being experienced from the perpetuation of specific national technical solutions and systems.

Five TSIs related to high-speed rail and three TSIs related to conventional rail are published. The progress of interoperability cannot only be measured through the national transposition of legislation, and it is important to determine the actual progress made with regards to the market for interoperable rail products and services, the number of subsystems in place, and the improvement in interoperability and reduction of technical barriers. 
Directive 2004/49/EC on the safety of the community's railways, adopted as part of the second package (the 'railway safety directive'), puts into place a harmonized framework and approach to rail safety and establishes the roles and responsibilities of the key actors, such as railway undertakings and infrastructure managers. The directive also requires member states to establish national safety authorities that are responsible for administering and managing some of the safety provisions described in the directive, and accident investigation bodies that will carry out investigations in order to establish their cause and background. The directive foresees the development of harmonized technical safety measures, such as CSTs and CSMs, and it is expected that these will establish links between the safety management of the railway and the technical requirements established by the TSIs. There is thus a clear relationship between interoperability directives and the safety directive, and technical solutions and safety shall be harmonized and established in a transparent manner, facilitating the removal of market entry barriers.

It is necessary for safety reasons to mandate that EU member states assign an identification code to each vehicle placed in service. The vehicle should then be entered in a national vehicle register. The registers must be open to consultation by all member states and by certain community economic players. The registers should be consistent as regards the data format. They should therefore be covered by common operational and technical specifications.

The adoption of a gradual approach satisfies the special needs of the objective of the interoperability of the rail system, which is characterized presently by old national infrastructure and vehicles requiring heavy investment for adaptation or renewal, and particular care should be taken not to penalise rail transport economically, vis-à-vis other modes of transport.

An urgent requirement is the preparation of a strategy to improve the interoperability of rail transport and reduce bottlenecks with a view to eliminating technical, administrative, and economic obstacles to the interoperability of networks without delay, while guaranteeing a high level of safety and training of the staff concerned.

After a subsystem is placed in service, care should be taken to ensure that it is operated and maintained in accordance with the essential requirements relating to it. Under Directive 2004/49/EC of the European Parliament and of the Council of 29 April, 2004, on safety on the community's railways (Railway Safety Directive) (1), the responsibility of meeting these requirements lies, for their respective subsystems, with the infrastructure manager or the railway undertaking. Member states can check compliance with these requirements when granting safety certificates and safety approvals pursuant to Articles $\mathrm{N}^{\circ} 10$ and $\mathrm{N}^{\circ} 11$ of the Railway Safety Directive. 


\subsection{Compatibility of the Eurasian railway systems}

The quality of rail services in Europe depends, inter alia, on excellent compatibility between the characteristics of the network (in the broadest sense, i.e., the fixed parts of all the subsystems concerned) and those of the vehicles (including the on-board components of all the subsystems concerned). The performance levels, safety, quality of service, and cost depend upon that compatibility.

The future success of the Eurasian railway land bridge strongly depends on the use of feedback of experiences, the ability to monitor and measure the progress of interoperability and recognise the reasons for the lack of progress.

While the interoperability provisions in the long run aim at allowing any compliant train to run on large portions of the European network, making the train and the track work together on a given project seems to be harder now in practice than earlier, when the infrastructure management and train operations were not separated. The main obstacle for new market entrants is still perceived to be the persisting diversity in technical and operational requirements for trains, staff, and operations.

\subsubsection{Major focus on railway safety}

The Common Safety Methods (CSM) apply when a major modification to the railway transport system is proposed. These methods harmonize the modification process and guarantee the fact that the existing safety levels are properly monitored and maintained. The overall objective of these safety measures related to risk assessment is to facilitate access to the railway transport service market and to allow cross-acceptance of the results of "EC regulation on common safety methods for risk assessment," No. 402/2013, published in the Official Gazette, that will come into force in May 2013.

The CSM facilitate access to the railway transport service market and favor crossacceptance of the results of risk assessment by harmonizing the risk management processes used to assess the safety levels and conformity of safety requirements, as well as the exchange of information between various players in the railway market with regard to safety assessment at the level of the various interfaces used in the railway sector; last but not least, they harmonize the results obtained by applying a risk management process (KEMA-RTC and DHV B.V. ... 2007).

The structural scheme of TSI implementation is presented in Figure 2. 


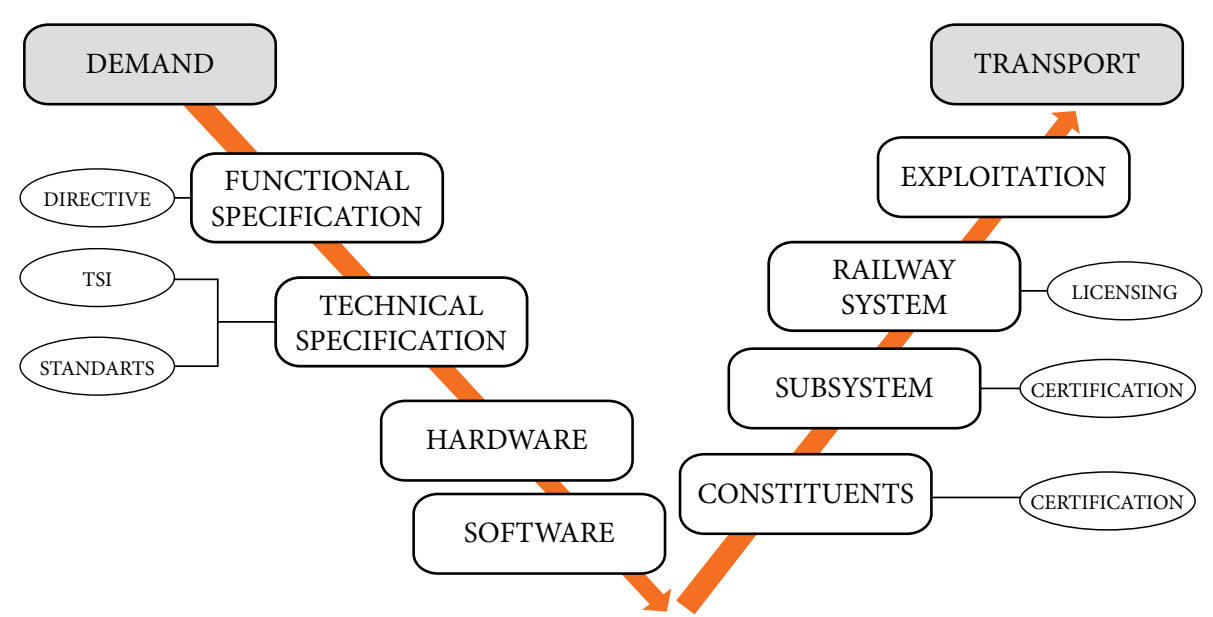

Figure 2. Design / Building / Development system / Use

(source: Project NEAR ${ }^{2}$. Deliverable D3.6 Concept Document "Safety and Security")

Starting in May 2013, this regulation will have to be applied to all the major technical modifications that affect vehicles, as defined in Article $N^{\circ} 2$, letter (c) of Directive $57 / 2008$, as well as to all the significant changes related to structural subsystems, as defined in Article $\mathrm{N}^{\circ} 15$, paragraph (1) of Directive 57/2008, or in accordance with the corresponding TSI.

\subsubsection{Railway subsystems}

1) Structural subsystems of a huge railway system are: infrastructure;

2) energy;

3) control;

4) command and signalling;

5) rolling-stock.

Railway functional (operational) subsystems are:

1) traffic operation and management;

2) maintenance;

3) telematics applications for passengers and freight.

\subsubsection{Requirements specific to each subsystem}

\section{Infrastructure}

1) Appropriate steps must be taken to prevent access to installations or undesirable intrusions. 
2) Steps must be taken to limit the dangers to which persons are exposed, particularly when trains pass through stations.

3) Infrastructure to which the public has access must be designed and made in such a way that limits any human safety hazards (stability, fire, access, evacuation, platforms, etc.).

4) Appropriate provisions must be laid down taking into account the particular safety conditions in very long tunnels and viaducts.

2. Energy

Operation of the energy supply systems must not impair the safety either of trains or of persons (users, operating staff, trackside dwellers, and third parties).

3. Control-command and signaling

The control-command and signaling installations and procedures used must enable trains to travel with a level of safety which corresponds to the objectives set for the network. The control-command and signaling systems should continue to provide for safe passage of trains permitted to run under degraded conditions.

4. Rolling stock (vehicle)

1) The rolling stock structures and those of the links between vehicles must be designed in such a way as to protect the passengers and the driving compartments in the event of a collision or derailment.

2) The electrical equipment must not impair the safety and functioning of the control-command and signaling installations.

3) The braking techniques and the stresses exerted must be compatible with the design of the tracks, engineering structures, and signaling systems.

4) Steps must be taken to prevent access to electrically-live constituents in order not to endanger the safety of persons.

5) In the event of danger, devices must enable passengers to inform the driver and accompanying staff to contact him.

6) The access doors must incorporate an opening and closing system that guarantees passenger safety.

7) Emergency exits must be provided and marked.

8) Appropriate provisions must be laid down taking into account the particular safety conditions in very long tunnels.

9) An emergency lighting system with sufficient intensity and duration is an absolute requirement on board trains.

10) Trains must be equipped with a public address system which provides a means of communication to the public from on-board staff. 


\section{Maintenance}

The technical installations and the procedures used in the centers must ensure the safe operation of the subsystem and not constitute a danger to health and safety.

6. Operation and traffic management

1) Alignment of the network operating rules and the qualifications of drivers, of the on-board staff, and of the staff in the control centers must exist to ensure safe operation, bearing in mind the different requirements of cross-border and optimizing services.

2) The maintenance operations and intervals, the training and qualifications of the maintenance and control center staff, and the quality assurance system set up by the operators concerned in the control and maintenance centers must be in such a way as to ensure a high level of safety.

7. Telematics applications for freight and passengers

1. The interfaces between these systems and the users must comply with the minimum rules on ergonomics and health protection.

2. Suitable levels of integrity and dependability must be provided for the storage or transmission of safety-related information. 


\section{SELECTION AND ANALYSIS OF EUROPE-ASIA RAILWAY INFRASTRUCTURE}

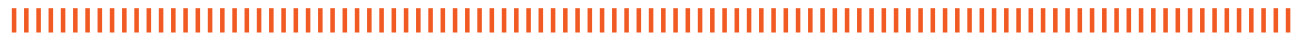

\subsection{Railway infrastructure constituents and elements}

\subsubsection{Maximum axle load}

The term load per axle means the vertical static load $Q$ separately transferred by each axle of a vehicle and in general of a train, through the wheels to the rails. If one considers a symmetric loading of the various vehicle parts, then the load per axle substantially expresses the quotient of the total vehicle weight to the total number of axles. The axle loads are initially exerted at the wheel-rail surface and then, through the different components of the track superstructure, they are transmitted to the substructure. During their transmission, the area of the surface of application of the internal forces increases, while the developing stresses decrease simultaneously.

Based on the permitted load per axle the tracks are classified into two basic groups:

I. Conventional axle-load tracks

In this group the static axle-load $\mathrm{Q}$ is $\leq 22.5 \mathrm{tf}$. The International Union of Railways (UIC) classifies these tracks, depending on the maximum permitted load per axle, into five categories: A, B, C, D and E (Table 1).

Each category is separated into sub-categories depending on the distributed load per metre of length (total vehicle load divided by the free length between buffers).

II. Heavy axle-load tracks

In this group the static axle-load Q is ranged between $245 \mathrm{kN}(25 \mathrm{tf})$ and $490 \mathrm{kN}$ (50 tf). 
Table 1. Categories of conventional axle-load tracks based on the permitted load per axle of trains in traffic (in accordance with UIC)

\begin{tabular}{cc} 
Track category & Load per axle (tf) \\
A & 16.0 \\
\hline B & 18.0 \\
\hline C & 20.0 \\
\hline D & 22.5 \\
\hline E & 25.0 \\
\hline
\end{tabular}

The maximum permitted load per axle is greatly significant in the dimensioning of the railway infrastructure and in determining the maintenance policy that should be implemented. More specifically, it affects the following (Table 2):

1. The choice of rails type: The increase of the axle load leads to the choice of heavier rails. Axle loads of $20 \mathrm{tf}, 25 \mathrm{tf}$, and $30 \mathrm{tf}$ require rails of minimum weight $50 \mathrm{~kg} / \mathrm{m}, 60 \mathrm{~kg} / \mathrm{m}$, and $70 \mathrm{~kg} / \mathrm{m}$ respectively. A $25 \%$ increase in the axle load requires a $20 \%$ increase in the rail weight.

2. The choice of the type of sleepers and sleepers' spacing

3. The choice of fastenings and dimensioning of elastic pads

4. The dimensioning of the track bed layers and the choice of gravel hardness

5. The geometry of the track alignment: The increase of the train load per axle leads to smaller permissible track gradients longitudinally.

6. The dimensioning of bridges

7. The track maintenance works: The influence of the vertical loads is catalytic to the track maintenance policy. The deterioration of the track quality is calculated as proportional to the third power of the axle load value. An increase of the axle load by $10 \%$ reduces the intervals occurring between the maintenance works by $30 \%$. It has been tested that the developing stress in the rail and therefore its wear, increase according to the $\left(\mathrm{Q}_{\mathrm{o}}\right) \mathrm{n}$ quantity. Where $\mathrm{n}$ is exponent with values between 3 and 4 , and $\mathrm{Q}_{\mathrm{o}}$ is load per wheel. The track defects are, among others, a function of the loads (static and dynamic) exerted by the rolling stock on the track and of the daily traffic load.

8. The choice of track gauge: The increase of the track gauge allows a significant increase of the load per axle. 
Table 2. Qualitative impact of axle load increase on the constituents and elements of a railway system-requirements

Axle load (Q)-Increase

Is lower in passenger trains (12-18) tf than in freight trains (16-50) tf
Increase: track design static load, train braking distance, track geometry defects deterioration rate, train running resistance

Requirements: less steep gradients, heavier rails, thicker track bed layers, longer signal spacing, greater traction power requirements, higher maintenance needs

The maximum permitted load per axle differs from railway network to railway network and in almost all countries, from railway corridor to railway corridor and even from track section to track section. The load per axle enters indirectly or directly into the analytical expressions of all the forces applied on the wheel-rail contact surface and affects the behaviour of both the rolling stock and the track.

In this framework, the load per axle is characterized as a strong interoperability issue. In Europe, in parallel to the effort of unification of the track gauge, an attempt is made to establish, in all countries, a unified permitted load per axle of $221 \mathrm{kN}(22.5 \mathrm{tf})$. In America train axle loads are twice as high as the European ones.

\subsubsection{Maximum train length}

The term maximum permitted train length (L) means the maximum length of a train composition that is permitted to circulate in a railway corridor. The train can be a hauled composition (power vehicles + trailer vehicles) or a train set (railcar). The length of a freight train varies from $400-800 \mathrm{~m}$ (conventional loads) to $1,000-4,000 \mathrm{~m}$ (heavy loads).

In Europe the length of trains can reach up to $750 \mathrm{~m}$; in the US it is larger (up to $2 \mathrm{~km}$ ) for transportation of conventional loads, whereas in Africa it can reach up to $4 \mathrm{~km}$ for transportation of heavy loads.

In the EU, the average trailer weight of freight trains reaches up to $1000 \mathrm{t}$, whereas in America trainloads are 10 or 20 times heavier, with axle load weight twice as high as the European ones and trains two or three times longer. In the EU, trial routes with trains of large axle load have been conducted, but only in Sweden, have trains of a weight reaching $8.160 \mathrm{t}$ (mixed load) been routed on a $43 \mathrm{~km}$ line. This comprises only $0.3 \%$ of the total length of the EU network.

The maximum permitted train length affects the constituents and elements of a railway system as shown in Table 3 . 
Table 3. Qualitative impact of train length and train weight increase to the constituents and elements of a railway system-requirements

\begin{tabular}{cc} 
Train length (L)-Increase & Decrease: \\
Is much smaller in passenger trains in relation & Track capacity \\
to freight trains & Requirements: \\
& Longer tracks and platforms in stations \\
\hline $\begin{array}{c}\text { Train weight (B)-Increase } \\
\text { Is much smaller in passenger trains in relation } \\
\text { to freight trains }\end{array}$ & $\begin{array}{c}\text { Increase: } \\
\text { Braking weight, train running resistance } \\
\text { Requirements: }\end{array}$ \\
& $\begin{array}{c}\text { Less steep gradients, longer signal spacing, } \\
\text { greater traction power requirements }\end{array}$ \\
\hline
\end{tabular}

The maximum permitted train length differs from railway corridor to railway corridor. To the extent that the train length affects the installations of the railway system, and more specifically the location of the signals in the signaling system, the platform's length, and the track layout of the stations, the maximum permitted train length is characterized as an interoperability issue.

\subsubsection{Track gauge}

Short definition of the topic:

The track gauge (2e) is the distance between the inside edges of the heads of a pair of rails. This distance is measured $14-16 \mathrm{~mm}$ below the rolling surface plane.

Based on the gauge, the railway tracks are divided into five categories:

A. Standard tracks or standard track gauge

This category mainly comprises the $1,435 \mathrm{~mm}$ gauge. This distance (4 feet and 8 inches) was ratified by the British engineer George Stephenson (1781-1848). As at that time most countries purchased their steam locomotives from England, that gauge has prevailed in most countries since then.

B. Broad tracks or broad track gauge

This category mainly comprises the following gauges: 1,520/1,524 $\mathrm{mm}$ (former Soviet countries), 1,600 mm (Irish gauge) and 1,668mm, 1,676mm (Spain, Portugal, India, Pakistan).

C. Meter tracks or meter track gauge

This category mainly comprises the following gauges: $914 \mathrm{~mm}, 950 \mathrm{~mm}, 1,000 \mathrm{~mm}$ (meter), 1,050 $\mathrm{mm}$, and 1,067 $\mathrm{mm}$ (Cape gauge).

D. Narrow tracks or narrow track gauge

This category comprises gauges from 600 to $900 \mathrm{~mm}$ and mainly $600 \mathrm{~mm}$ (Decauville), $700 \mathrm{~mm}, 750 \mathrm{~mm}$, and $760 \mathrm{~mm}$ (Bosnian gauge). These gauges are usually used in secondary lines (industrial areas, factories, mine service lines). 


\section{E. Mixed gauge tracks}

This category comprises tracks that allow rolling stock with standard gauge axles and those with meter gauge axle to move on the same track sections.

Regardless of the track gauge category, the distance between the rails remains the same throughout the network length, except in the curved alignment sections with small curvature radius $(<250-300 \mathrm{~m})$, where in many cases a widening of the track gauge is permitted to facilitate the inscription of vehicle axles (gauge widening).

The increase of the track gauge presents advantages and disadvantages:

1. It improves the vehicle stability, and therefore enables higher speeds.

2. It enables the construction of wider vehicles; therefore, it provides the possibility for movement of larger shipments and also for a more comfortable design of the inner-vehicle spaces.

3. It increases significantly the track construction cost. Indicatively it is mentioned that the construction of a metric line is estimated to cost 30 percent less than the construction of a standard gauge line.

Given the above, the standard track gauge $(1435 \mathrm{~mm})$, being the most common and also comparatively large, has been established in most countries. Many countries (like Spain, Japan, Thailand, etc.) have already begun the gradual replacement of their tracks with tracks of standard gauge. In Europe, the standard gauge prevails. Table 4 indicates the existing railway track gauges and the countries in which these are applied.

Table 4. Railway track gauges worldwide

\begin{tabular}{|c|c|c|}
\hline $\begin{array}{l}\text { Track gauge } \\
(\mathrm{mm})\end{array}$ & Type & Countries applied \\
\hline 1676 & Indian track & $\begin{array}{c}\text { India (Project "Unigauge": } 42,000 \mathrm{~km} \text { ), Pakistan, } \\
\text { Argentina, Chile }\end{array}$ \\
\hline 1668 & Iberian track & Portugal, Spain \\
\hline 1600 & Irish track & $\begin{array}{c}\text { Ireland, partly Australia-“Victorian track" }(4,017 \mathrm{~km}) \text {, } \\
\text { Brazil }(4,057 \mathrm{~km})\end{array}$ \\
\hline 1524 & \multirow[b]{2}{*}{ Russian track } & Finland, Estonia (also use $1520 \mathrm{~mm}$ ) \\
\hline 1520 & & $\begin{array}{l}\text { CIS countries, Latvia, Lithuania, Estonia (also use } \\
1524 \mathrm{~mm} \text { ), Mongolia (only 17\% of railways) }\end{array}$ \\
\hline 1435 & Standard track & $\begin{array}{l}\text { Central and Western Europe, USA, Canada, China, Korea, } \\
\text { Australia, the Middle East, North Africa, Mexico, Cuba, } \\
\text { Panama, Venezuela, Peru, Uruguay (only } 60 \% \text { of railways) }\end{array}$ \\
\hline 1067 & Cape track & $\begin{array}{l}\text { South and Central Africa, Indonesia, Japan, Taiwan, } \\
\text { the Philippines, New Zealand and Australia in part, the } \\
\text { Sakhalin Railway (Russia) ( } 9 \% \text { of the railways) }\end{array}$ \\
\hline 1000 & Meter track & $\begin{array}{c}\text { South-East Asia, India }(17,000 \mathrm{~km}) \text {, Brazil }(23,489 \mathrm{~km}) \text {, } \\
\text { Bolivia, northern Chile, Kenya, Uganda } \\
\text { (only } 7 \% \text { of railways) }\end{array}$ \\
\hline
\end{tabular}


Track gauge is closely related to the maximum permitted axle load, the width of the right of way of the track infrastructure, and the vehicles' width. Considering this is the case, track gauge affects almost all the constituents and elements of the railway infrastructure, and defines, to a large extent, the efficiency of the railway freight transport.

The track gauge varies from country to country, and in many countries, from railway corridor to railway corridor. To the extent that the track gauge affects all the elements of the railway infrastructure and does not permit the seamless railway connection of neighbouring countries that have different track gauges, this aspect is characterized as a very strong interoperability issue.

\subsubsection{Maximum speed of freight and passenger trains}

Generally speaking, with respect to railways, speed is defined in different ways, depending on the technical and/or operational expression it may assume.

I. Commercial speed $\left(V_{c}\right)$ is defined as the ratio of the length of a railway line (e.g., between two terminal stations) to the time it takes to cover it, including dwell times at intermediate stations and delays. Commercial speed always refers to a particular type of train.

II. Running or cruiser speed $\left(V_{\mathrm{r}}\right)$ is defined as the ratio of the length of a railway track section (e.g. between two intermediate stations) to the time it takes to cover it under normal traffic conditions (i.e., no unexpected delays). Running speed always refers to a particular type of train. In cases where more than one section is considered, the average running speed (Var) is taken into account.

III. Permissible track speed $\left(V_{\text {maxtr }}\right)$ is defined as the maximum speed that may be developed on a railway track section. The speed is determined by the IM, based on the prevailing conditions of the infrastructure. This speed is usually different for different categories of trains (passenger trains, freight trains) sharing the same railway infrastructure.

IV. Design speed $\left(V_{\mathrm{d}}\right)$ is defined as the speed for which the track layout has been designed and the infrastructure has been constructed (superstructure, substructure, civil engineering structures, and installations). Thus, it is regarded as the maximum speed at which a train can safely and with comfort circulate on a specific track. If possible, the design speed should be the same on all track sections.

The relationship between the aforementioned speeds is given below:

$$
V_{\mathrm{c}} \leq V_{\mathrm{r}}<V_{\text {maxtr }} \leq V_{\mathrm{d}} .
$$

The quality of the railway infrastructure, with regard to speed, is ensured when the permissible track speed (Vmaxtr) of the individual track sections matches the track design speed $\left(V_{\mathrm{d}}\right)$. 
Based on the design speed $\left(V_{\mathrm{d}}\right)$ the tracks are classified into three basic groups:

I. Very high speed tracks $\left(V_{\mathrm{d}} \geq 250 \mathrm{~km} / \mathrm{h}\right.$ and $\left.V_{\mathrm{c}}>200 \mathrm{~km} / \mathrm{h}\right)$

II. High speed tracks $\left(250 \mathrm{~km} / \mathrm{h}>V_{\mathrm{d}} \geq 200 \mathrm{~km} / \mathrm{h}\right.$ and $\left.V_{\mathrm{c}} \geq 150 \mathrm{~km} / \mathrm{h}\right)$

III. Conventional speed tracks $\left(V_{\mathrm{d}}<200 \mathrm{~km} / \mathrm{h}\right)$.

The maximum applicable speed of passenger trains ranges actually between 100 and $350 \mathrm{~km} / \mathrm{h}$. The maximum speed of freight trains ranges between 60 and $120 \mathrm{~km} / \mathrm{h}$. The transportation of heavy loads requires slower speeds $(60-100 \mathrm{~km} / \mathrm{h})$.

Table 5 presents the railway elements that are affected by train speed.

Table 5. Qualitative impact of train features on the constituents and elements of a railway system-requirements

Train / vehicle feature: qualitative influence
Effects on the railway system constituents and elements-Requirements

Increase: Track design dynamic load, train braking distance, centrifugal effort in curves, aerodynamic train resistance, track capacity, consequences in case of accident

Speed (V)-Increase Is greater for passenger trains (100-350) $\mathrm{km} / \mathrm{h}$ than for freight trains $(60-120) \mathrm{km} / \mathrm{h}$
Requirements: Larger axial distance between tracks, higher curvature radius in the longitudinal and vertical alignment, higher track cant, greater length of transition curves in the horizontal alignment, continuously welded and heavier rails, concrete sleepers, elastic fasteners, thicker track bed, track fencing, electric signaling, longer signal spacing, electrification (for $V>160 \mathrm{~km} / \mathrm{h}$ ), specific rolling stock, slow train overtaking, increased safety measures along the track, bigger tunnel cross-section, higher maintenance needs

The parameter speed is not an interoperability issue. Freight trains can develop different running speeds in different sections of the network.

\subsubsection{Track Capacity}

Track section capacity is defined as the maximum number of trains that can run on a track section during a certain time period ( 24 hours, 12 hours, 1 hour, etc.), whereby both the particular conditions of track operation and exploitation and the adherence to rules, which ensure a good level of service, have to be taken into consideration. The capacity of a track section is determined on the basis of its critical subsection.

The available capacity of a certain track section $\left(C_{\mathrm{d}}\right)$, during a reference time period $\left(\mathrm{T}_{\text {ref }}\right)$, is defined as the difference between the practical capacity $\left(C_{\mathrm{p}}\right)$ of the track section during the reference period and the number of trains $(N)$ that have been scheduled to circulate during the same period. In other words, it expresses the 
number of additional trains that can circulate on the examined track section during the reference time period.

$$
C_{\mathrm{d}}=C_{\mathrm{p}}-N
$$

The saturation ratio of a track section $\left(S_{s}\right)$, during a reference time period $\left(T_{\text {ref }}\right)$, corresponds to the ratio of the number of trains actually scheduled for this period $(N)$ over the practical capacity $\left(C_{\mathrm{p}}\right)$ of the track section during the reference time period:

$$
S_{S}=\frac{N}{C_{p}} .
$$

It is expressed as a percentage.

The track capacity depends on various parameters of the track, the rolling stock, and the operation and exploitation conditions. The parameter that has the most important influence is the number of tracks. A double track (two tracks with one-way traffic operation) has twice the capacity of a single one (one track with bidirectional traffic operation).

Saturation ratio can get values higher than $100 \%$, in case the number of passing trains exceeds the practical capacity, which is the case when the dilation margin lower than the scheduled one is applied.

The parameters that affect track capacity and are related to the infrastructure are:

a) the number of tracks available to traffic;

b) the signaling equipment (mechanical or electrical signaling, length of block sections, equipment used to detect train's presence, etc.);

c) the maximum permitted speed on different sections;

d) the local speed limits, due to different reasons;

e) the maintenance requirements; and

f) the position of stations and switches.

The track capacity along the track sections of a railway corridor is not an interoperability issue. It is of high importance, though, for freight railway transport, given that it defines the ability of routing additional trains in a rail corridor and affects the itinerary reliability.

\subsubsection{Rolling stock static and dynamic gauge (clearance)}

Generally, the term "gauge" refers to the maximum outline that has to be available around the rolling stock in order for it to be able to move along the tracks. Based on factors that are taken into consideration for the determination of the gauge, the following types of gauge are distinguished:

1) The "rolling stock" gauge

2) The "civil engineering structures" gauge or "fixed obstacle" gauge 
The rolling stock gauge is categorized as:

a) static gauge or loading gauge;

b) dynamic gauge or kinematic gauge; and

c) electrification gauge.

The "fixed obstacle" gauge is the layout within which the existence of any obstacle (i.e., civil engineering structures, electrification or signaling columns, track change devices, etc.) is forbidden. The fixed obstacle gauge is used in order to define the inner cross section of tunnels and the height clearance.

Different fixed obstacle gauges are applied (e.g., GC, GB, etc.) and some countries apply their own gauge. The effect of the rolling stock gauge on the components/elements of the railway system is mostly related to the necessary distance between the railway tracks (minimum axial distance between tracks), as well as the clearance under the structures.

The relation between the gauge interfaces and civil engineering structures is mostly identified as follows:

1. The dimensioning of the useful section of a tunnel.

2. The estimation of the height between the wheel-rail surface and the bottom surface of the body of the civil engineering structure.

In cases of passenger train movement at speeds $V \geq 200 \mathrm{~km} / \mathrm{h}$, a verification of both the geometric and the aerodynamic efficiency of the useful cross section of tunnels is required, with the second control being more adverse, thus defining the surface of the section used. On the contrary, in cases of conventional speed passenger trains or freight trains, only a verification of the geometric efficiency is required.

In terms of the estimation of the height clearance, this is affected, inter alia (i.e. the electrification installations), by the height of the kinematic gauge of the vehicles, which, in the cases of freight trains, is bigger.

The applied rolling stock static and dynamic gauge (clearance) varies from country to country and in many countries, from railway corridor to railway corridor. To the extent that the static and dynamic and electrification gauge could prohibit the passage of a train in a railway section, this aspect is characterized as a very strong interoperability issue.

\subsubsection{Traction system}

Short definition of the topic

Depending on the source of power used for the train's movement, the following traction systems are identified: diesel, and electrification. 


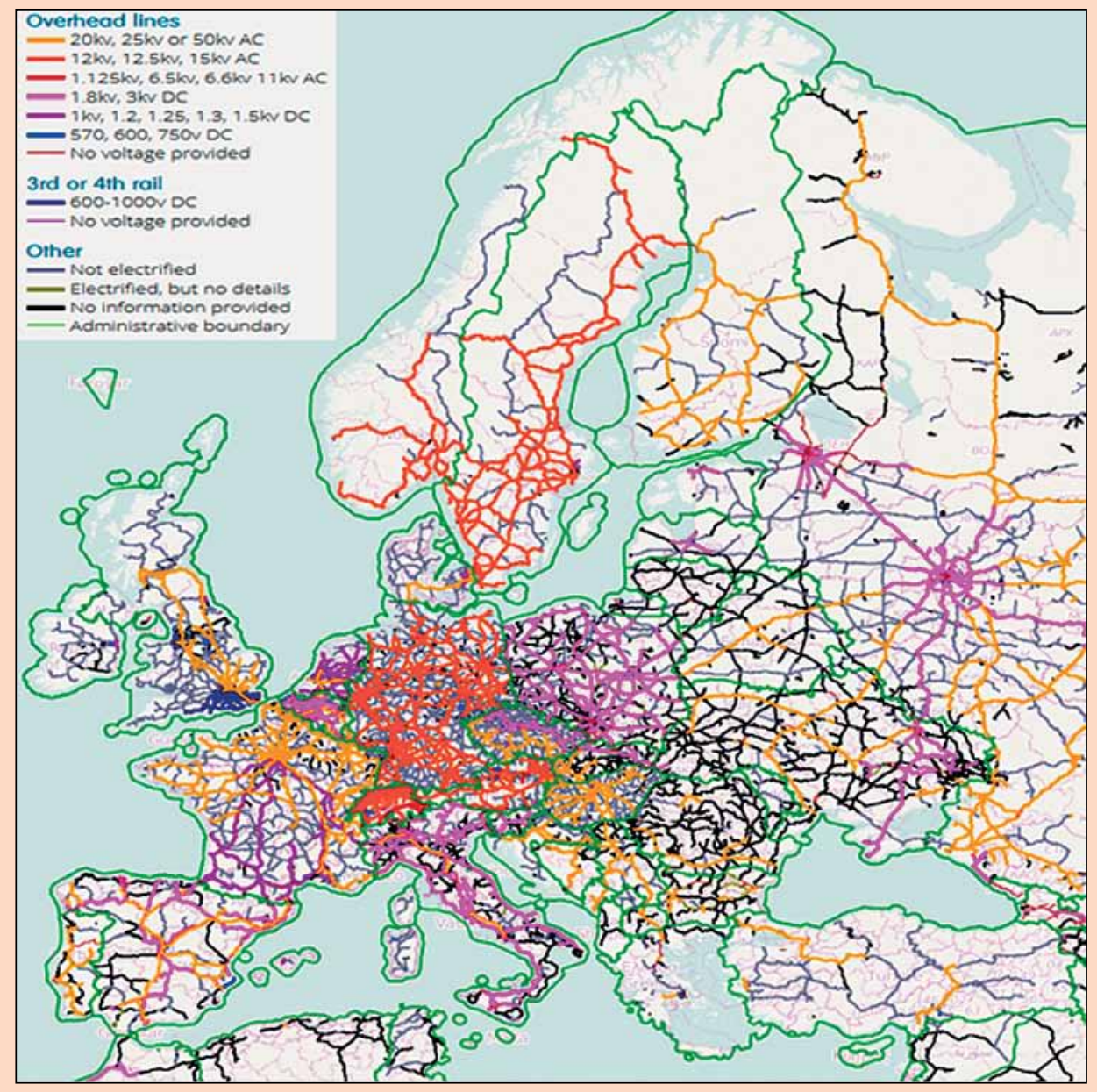

Figure 3. Electrification systems of railway lines in Europe (source: http://www.itoworld.com/map/68)

The comparison between electrification and diesel traction is based on four criteria, namely:

1) technical;

2) energy;

3) economical; and

4) environmental;

The technical and environmental criteria attribute a clear advantage to electrification. The energy criterion treats both tractions in the same way, while in the case 


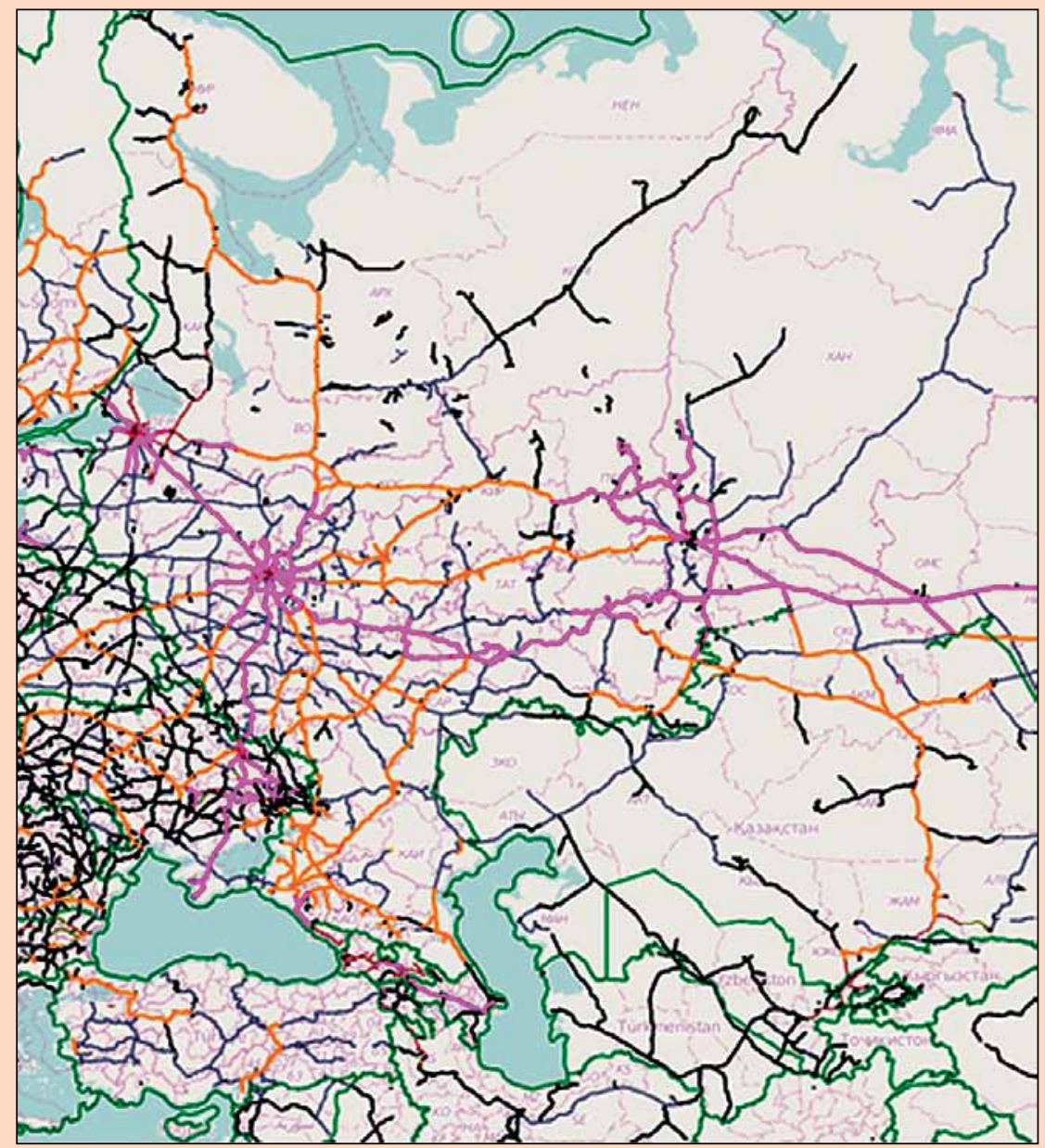

Figure 4. Electrification systems of railway lines in Central Asia (source: http://www.itoworld.com/map/68)

of the economical criterion, the situation is more complicated, since electrification presents advantages when the traffic exceeds a certain threshold (performance threshold).

Trains of high speeds $(>200 \mathrm{~km} / \mathrm{h})$ are mandatorily electrified, while for freight trains both solutions are adopted. When compared with diesel traction, electrification enables considerably enhanced fuel efficiency even allowing for transmission losses; it enables much higher specific installed power in the traction unit; it 


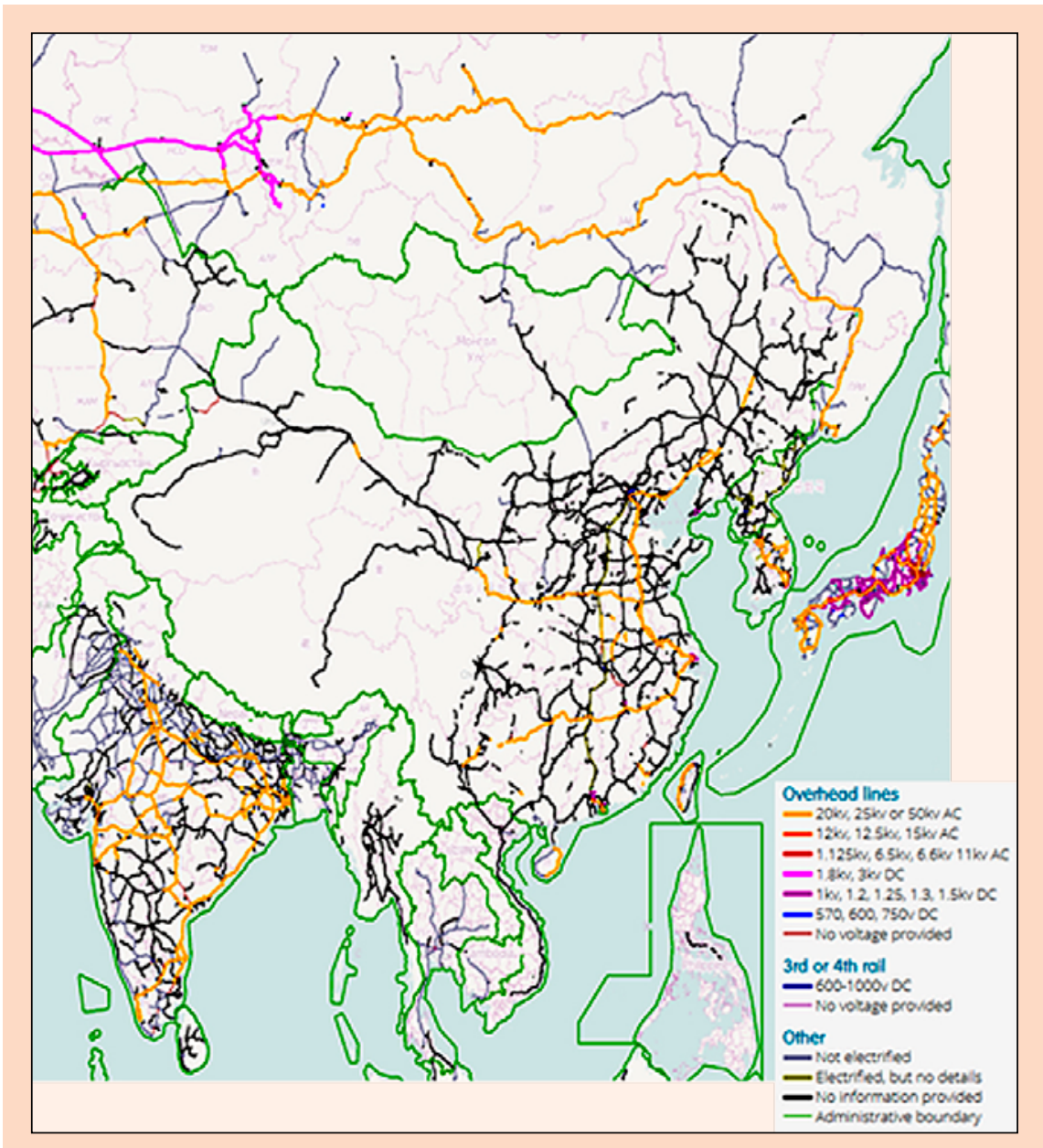

Figure 5. Electrification systems of railway lines in Central and East Asia (source: http://www.itoworld.com/map/68)

substantially reduces maintenance costs and out-of-service times for the traction units; it enables more responsive control; and it avoids discharge of products of combustion in urban areas. In a few systems, regenerative brakes return some electric energy from the train.

The disadvantages of electrification include the high capital costs of setting up the energy distribution system; a corresponding inability to provide a cheap service to lightly trafficked routes; and a relative lack of flexibility in the event of route disruption. 
Different electrical supply standards in adjacent regions complicate the service. Low overhead clearances in many electrified systems prevent the implementation of efficient double-stack container service.

Electrification systems are classified based on three main parameters: voltage, current (DC or AC), and frequency. Six of the most commonly used voltages have been selected for European and international standardization. The permissible range of voltages allowed for the standardized voltages is as stated in standards BS EN 50163 and IEC 60850:

1. $600 \mathrm{~V} \mathrm{DC}$

2. $750 \mathrm{~V} \mathrm{DC}$

3. $1.5 \mathrm{kV} \mathrm{DC}$

4. $3 \mathrm{kV} \mathrm{DC}$

5. $15 \mathrm{kV}$ AC $16.7 \mathrm{~Hz}$

6. $25 \mathrm{kV} \mathrm{AC} 50 \mathrm{~Hz}$

The railway electrification systems in Europe and Asia are shown in Figure 3, Figure 4 and Figure 5. Colour lines are used for electrified lines, and grey lines are used for non-electrified lines; black lines indicate that there is no information about electrification for the line.

In cases of electric freight trains, compatibility between the electrification equipment of the rolling stock and the track installations is necessary. To the extent that this aspect could prohibit the movement of a train across a railway section, it is characterized as a very strong interoperability issue. On the contrary, in cases of diesel trains, there is no interoperability issue.

\subsubsection{Signaling System}

The main purpose of the railway signaling system is the safe movement of the trains along the tracks, and more specifically:

1) the avoidance of collision between trains (frontal, rear end, lateral and side collision);

2) the avoidance of unsafe handling in switches and crossings;

3) the transverse protection of the trains at level crossings with road arteries or at pedestrians' or animals' crossings; and

4) the avoidance of derailment at the network segments where a speed limit is imposed.

In addition to these, the railway signaling enables the optimization of the use of the track capacity, namely the routing of a larger number of freight trains that can move safely along the tracks, under certain conditions of line exploitation and operation. 
There are two types of signaling systems:

I. Mechanical signalling

II. Electric signalling

Mechanical signaling uses signs located on the side of the tracks (vertical signs), which are identified by their shape, color, and context. Mechanical signaling is implemented with small boards, panels, or semaphores.

Electric signaling is implemented with:

I. Colour-light signals: Side-track light signaling system is used for trains that move at speeds less than (200-220) $\mathrm{km} / \mathrm{h}$ in conventional speed networks.

II. Messages that are directly displayed on the driver's cab (cab signalling): This system is mandatory in networks of high speed trains $(V>220 \mathrm{~km} / \mathrm{h})$ and demands the transmission/ reception of information between the track and the vehicle.

Signaling systems vary from country to country and, in all countries, from railway corridor to railway corridor. To the extent that this could minimize the safety of the train movement along a railway section, it is characterized as a strong interoperability issue.

\subsubsection{Track maintenance}

Maintenance is a horizontal activity and concerns all the components of a railway system (track, rolling stock, exploitation). Track maintenance is a very important issue for the efficiency and safety of passenger and goods transportation. (Podofillini et al. 2006).

In the case of railway systems, especially large systems, it is necessary to apply a systematic approach to maintenance management. The EU railway market uses European standards EN 50126, EN 50129, EN 50128, that show the way of application of requirements, methods, procedures, and criteria for railway applications. They also solve the RAMS (Reliability, Availability, Maintenance, Safety) issues and they bring in the base background for independent safety assessors. These standards are valid in many industrial countries in the EU.

The standard CENELEC EN 50126 has been mandatory for rail systems since 2001. It defines the processes and requirements that the track operator and rail industry should systematically use in all stages of the life cycle of railway equipment. Such an approach not only minimizes potential systematic errors design, but eliminates the risk of erroneous entries, thus minimizing potential economic losses associated with these errors. The system-level approach defined by this standard makes an assessment of the interaction between RAMS elements of complex railway facilities easier. 
The processes defined in this standard are related to cooperation between the infrastructure manager and the railway industry, and aim at ensuring the achievement of the optimum combination of RAMS and the cost of the railways. The process defined in the standard assumes that the rail system and the rail industry have policies on quality, efficiency, and safety level of trade. The approach defined in this standard corresponds to application requirements for quality management contained in a set of international standards (ISO 9000). Together with process management, it is necessary for the control and safety systems to use standards CENELEC EN 50128 and CENELEC EN 50129. To install these systems related to safety, it is necessary to take into account both parts throughout the system life cycle. The CENELEC EN 50128 standard focuses on the methods to be used to ensure that the software meets the demands for safety integrity.

For the EU-Asia connection, it is necessary to determine generally accepted methodologies and processes, including the documentation of the risk management process, which allows accurate determination and demonstration of RAMS parameters for railway systems both on the supply side, judges, national regulators or authorities, and on that of the customers (operators). In cases where there are no generally accepted methodologies and processes, it could bring a series of contradictions, imbalances, inconsistent practices, or disagreements between suppliers, judges, national regulators or authorities, and customers or operators. Therefore, this issue has a direct relation with interoperability problems.

The maintenance techniques, methods, and policies vary from country to country. To the extent that this could minimize the safety and the speed of the train movement along a railway section, it is characterized as an interoperability issue.

Following the identification of existing alternative railway routes that connect Western/Central Europe to Asia, the next step was to create a table with the railway network characteristics. Table 6 summarizes the current values of the railway network in Eurasian Railways. The values are provided per crossing country of the considered railway routes. The railway segments materializing the railway route at the level of each country are also identified. 
Table 6. Crossing countries of the Europe-Asia railway connection routes-Railway segments per country materializing the routes

A. Connection: Western Europe-Russian Far East-Japan

A1. Via main Trans-Siberian railway network

\begin{tabular}{|c|c|c|c|}
\hline Crossing countries & Poland & Ukraine & Russia \\
\hline $\begin{array}{l}\text { Route/crossing points } \\
\text { within the country }\end{array}$ & Warsaw & Kiev & $\begin{array}{c}\text { Moscow- } \\
\text { Vladimir-Perm, } \\
\text { Yekaterinburg- } \\
\text { Omsk- } \\
\text { Novosibirsk-Ulan } \\
\text { Ude-Vladivostok } \\
\text { (port) }\end{array}$ \\
\hline Corridor/Network & TINA, OSJD $1^{4}$ & $\begin{array}{c}\text { AGC Network } \\
(\text { E30, E50, E95 })^{5} \\
\text { OSJD } 7\end{array}$ & $\begin{array}{l}\text { Trans-Siberian, } \\
\text { AGC Network } \\
\text { (E20), TAR }{ }^{6} \\
\text { OSJD } 1\end{array}$ \\
\hline Track gauge $(\mathrm{mm})$ & 1435 & 1520 & 1520 \\
\hline$\underset{(\mathrm{tf})}{\text { Max permitted axle load }}$ & 22.5 & & 23.5 \\
\hline $\begin{array}{l}\text { Max permitted train length } \\
(\mathrm{m})\end{array}$ & 750 & 1200 & 1300 \\
\hline Traction system ${ }^{7}$ & $3 \mathrm{kV} \mathrm{DC}$ & $\begin{array}{c}\text { 25kV-50Hz system AC } \\
\text { (Eastern Ukraine) } \\
3 \mathrm{kV} \mathrm{DC} \\
\text { (Western Ukraine) }\end{array}$ & $\begin{array}{c}3 \mathrm{kV} \mathrm{DC} \\
25 \mathrm{kV} \mathrm{AC} 50 \mathrm{~Hz}\end{array}$ \\
\hline Signaling system ${ }^{8}$ & ERTMS & $\begin{array}{l}\text { Automatic Block } \\
\text { Signaling }\end{array}$ & $\begin{array}{l}\text { Automatic Block } \\
\text { Signaling }\end{array}$ \\
\hline $\begin{array}{l}\text { Track capacity }{ }^{9}: \\
\text { Number of tracks }\end{array}$ & High & $\begin{array}{l}\text { Max. } 210 \text { trains/day } \\
\text { (current } 160 \text { trains/day) }\end{array}$ & High \\
\hline $\begin{array}{l}\text { Max speed of freight trains } \\
\qquad(\mathrm{km} / \mathrm{h})\end{array}$ & 100 & 90 & 90 \\
\hline $\begin{array}{l}\text { Max speed of passenger } \\
\text { trains }(\mathrm{km} / \mathrm{h})\end{array}$ & 140 & 160 & 140 \\
\hline
\end{tabular}

\footnotetext{
4 Euro-Asian rail transport corridors of the Organization for Cooperation of Railways (OSJD)

5 UNECE European Agreement on Main International Railway Lines (AGC)

6 Trans-Asian Railway Network

7 Please indicate the type of traction: electric, diesel. If you choose electric, please indicate the type of current $(\mathrm{AC}, \mathrm{CC})$ the current voltage and frequency.

8 Please indicate the signaling system (i.e. mechanical, lateral electric, ERTMS, etc.)

9 Please indicate the saturation rate: high, medium, low
} 
B. Connection: Western Europe-China via the Trans-Siberian Route and its branches

B1. Via branch of the Trans-Siberian railway network and the Manchurian Route

\begin{tabular}{|c|c|c|c|c|}
\hline Crossing countries & Poland & Ukraine & Russia & China \\
\hline $\begin{array}{l}\text { Route/crossing } \\
\text { points within the } \\
\text { country }\end{array}$ & Warsaw & Kiev & $\begin{array}{c}\text { Moscow- } \\
\text { Vladimir-Perm, } \\
\text { Yekaterinburg- } \\
\text { Omsk- } \\
\text { Novosibirsk-Ulan } \\
\text { Ude-Karimskaya- } \\
\text { Borzya }\end{array}$ & $\begin{array}{l}\text { Manzhouli-Harbin- } \\
\text { Shenyang-Beijing }\end{array}$ \\
\hline Corridor/Network & $\begin{array}{l}\text { TINA, } \\
\text { OSJD } 1\end{array}$ & $\begin{array}{c}\text { AGC } \\
\text { Network } \\
\text { (E30, E50, } \\
\text { E95), OSJD 7 }\end{array}$ & $\begin{array}{c}\text { Trans-Siberian, } \\
\text { AGC Network } \\
\text { (E20), TAR, OSJD } 1\end{array}$ & TAR \\
\hline Track gauge $(\mathrm{mm})$ & 1435 & 1520 & 1520 & $1435^{10}$ \\
\hline $\begin{array}{l}\text { Max permitted axle } \\
\text { load (tf) }\end{array}$ & 22.5 & - & 23.5 & 23.0 \\
\hline $\begin{array}{l}\text { Max permitted } \\
\text { train length }(\mathrm{m})\end{array}$ & 750 & 1200 & 1300 & 900 \\
\hline Traction system & $3 \mathrm{kV} \mathrm{DC}$ & $\begin{array}{c}3 \mathrm{kV} \mathrm{DC} \\
25 \mathrm{kV} \mathrm{AC} \\
50 \mathrm{~Hz}\end{array}$ & $\begin{array}{c}3 \mathrm{kV} \mathrm{DC} \\
25 \mathrm{kV} \mathrm{AC} 50 \mathrm{~Hz}\end{array}$ & $\begin{array}{l}\text { Non-electrified } \\
25 \mathrm{kV} \text { AC } 50 \mathrm{~Hz}\end{array}$ \\
\hline Signaling system & ERTMS & $\begin{array}{l}\text { Automatic } \\
\text { Block } \\
\text { Signalling }\end{array}$ & $\begin{array}{l}\text { Automatic Block } \\
\text { Signalling }\end{array}$ & Lateral electric \\
\hline $\begin{array}{l}\text { Track capacity: } \\
\text { number of tracks }\end{array}$ & High & unknown & High & High \\
\hline $\begin{array}{l}\text { Max speed of } \\
\text { freight trains } \\
\quad(\mathrm{km} / \mathrm{h})\end{array}$ & 100 & 90 & 90 & 90 \\
\hline $\begin{array}{l}\text { Max speed of } \\
\text { passenger trains } \\
(\mathrm{km} / \mathrm{h})\end{array}$ & 140 & 160 & 140 & 90 \\
\hline
\end{tabular}

10 (Ziyadov, 2011, p. 74) 
B. Connection: Western Europe-China via the Trans-Siberian Route and its branches

B2. Via branch of the Trans-Siberian railway network and the Trans-Kazakh Route

\begin{tabular}{|c|c|c|c|c|c|}
\hline $\begin{array}{l}\text { Crossing } \\
\text { countries }\end{array}$ & Poland & Ukraine & Russia & Kazakhstan & China \\
\hline $\begin{array}{l}\text { Route/crossing } \\
\text { points within } \\
\text { the country }\end{array}$ & Warsaw & Kiev & $\begin{array}{c}\text { Moscow-Vla- } \\
\text { dimir-Perm, } \\
\text { Yekaterin- } \\
\text { burg-Kurgan }\end{array}$ & $\begin{array}{l}\text { Presnogorkovka- } \\
\text { Astana-Aqtoghay }\end{array}$ & $\begin{array}{c}\text { Lanzhou- } \\
\text { Zhengzhou- } \\
\text { Beijing }\end{array}$ \\
\hline $\begin{array}{l}\text { Corridor/ } \\
\text { Network }\end{array}$ & $\begin{array}{l}\text { TINA, } \\
\text { OSJD } 1\end{array}$ & $\begin{array}{c}\text { AGC } \\
\text { Network } \\
\text { (E30, E50, } \\
\text { E95), } \\
\text { OSJD 7 }\end{array}$ & $\begin{array}{c}\text { Trans- } \\
\text { Siberian, } \\
\text { AGC Network } \\
\text { (E24), TAR, } \\
\text { OSJD 1, } 2\end{array}$ & $\begin{array}{l}\text { Northern TAR, } \\
\text { AGC Network } \\
\text { (E24, E50), } \\
\text { OSJD } 2\end{array}$ & TAR, OSJD 2 \\
\hline $\begin{array}{l}\text { Track gauge } \\
(\mathrm{mm})\end{array}$ & 1435 & 1520 & 1520 & $1520^{11}$ & 1435 \\
\hline $\begin{array}{l}\text { Max permitted } \\
\text { axle load (tf) }\end{array}$ & 22.5 & - & 23.5 & $13^{12}$ & 23.0 \\
\hline $\begin{array}{l}\text { Max permitted } \\
\text { train length (m) }\end{array}$ & 750 & 1200 & 1300 & 850 & 850 \\
\hline $\begin{array}{l}\text { Traction } \\
\text { system - } \\
\text { number of } \\
\text { tracks }\end{array}$ & $3 \mathrm{kV} \mathrm{DC}$ & $\begin{array}{c}3 \mathrm{kV} \mathrm{DC} \\
25 \mathrm{kV} \mathrm{AC} \\
50 \mathrm{~Hz}\end{array}$ & $\begin{array}{c}3 \mathrm{kV} \mathrm{DC} \\
25 \mathrm{kV} \mathrm{AC} 50 \\
\mathrm{~Hz}\end{array}$ & $\begin{array}{l}\text { Non-electrified } \\
25 \mathrm{kV} \text { AC } 50 \mathrm{~Hz}\end{array}$ & $\begin{array}{c}\text { Non- } \\
\text { electrified } \\
25 \mathrm{kV} \mathrm{AC} 50 \\
\mathrm{~Hz}\end{array}$ \\
\hline $\begin{array}{l}\text { Signaling } \\
\text { system }\end{array}$ & ERTMS & $\begin{array}{l}\text { Automatic } \\
\text { Block } \\
\text { Signalling }\end{array}$ & $\begin{array}{l}\text { Automatic } \\
\text { Block } \\
\text { Signalling }\end{array}$ & $\begin{array}{l}\text { Automatic Block } \\
\text { Signalling }\end{array}$ & $\begin{array}{l}\text { Lateral } \\
\text { electric }\end{array}$ \\
\hline Track capacity & High & $\begin{array}{c}\text { Max. } 210 \\
\text { trains/day } \\
\text { (current } 160 \\
\text { trains/day) }\end{array}$ & High & Medium & Medium \\
\hline $\begin{array}{l}\text { Max speed of } \\
\text { freight trains } \\
\quad(\mathrm{km} / \mathrm{h})\end{array}$ & 100 & 90 & 90 & 90 & 90 \\
\hline $\begin{array}{l}\text { Max speed } \\
\text { of passenger } \\
\text { trains }(\mathrm{km} / \mathrm{h})\end{array}$ & 140 & 160 & 140 & 140 & 100 \\
\hline
\end{tabular}

${ }^{11}$ At around 2005, the Kazakhstani government and Kazakh Railways strongly promoted the project to construct the narrow $1435 \mathrm{~mm}$ gauge railway from Dostyk to Gorgan, however, nothing has been heard about these plans since yet (Kulipanova, 2012, p.23).

12 (PADECO Co., 2006, p.259) 
B. Connection: Western Europe-China via the Trans-Siberian Route and its branches

B3. Via branch of the Trans-Siberian railway network and the Mongolian Route

\begin{tabular}{|c|c|c|c|c|c|}
\hline $\begin{array}{l}\text { Crossing } \\
\text { countries }\end{array}$ & Poland & Ukraine & Russia & Mongolia & China \\
\hline $\begin{array}{l}\text { Route/crossing } \\
\text { points within } \\
\text { the country }\end{array}$ & Warsaw & Kiev & $\begin{array}{c}\text { Moscow- } \\
\text { Vladimir- } \\
\text { Perm, } \\
\text { Yekaterinburg- } \\
\text { Omsk- } \\
\text { Novosibirsk- } \\
\text { Ulan Ude- } \\
\text { Naushki }\end{array}$ & $\begin{array}{l}\text { Darhan- } \\
\text { Ulaanbaatar- } \\
\text { Choir }\end{array}$ & $\begin{array}{c}\text { Erenhot- } \\
\text { Datong- } \\
\text { Beijing }\end{array}$ \\
\hline $\begin{array}{l}\text { Corridor/ } \\
\text { Network }\end{array}$ & $\begin{array}{l}\text { TINA, } \\
\text { OSJD } 1\end{array}$ & $\begin{array}{c}\text { AGC } \\
\text { Network } \\
\text { (E30, E50, } \\
\text { E95), OSJD } 7\end{array}$ & $\begin{array}{c}\text { Trans- } \\
\text { Siberian, AGC } \\
\text { Network (E20), } \\
\text { TAR, OSJD } 1\end{array}$ & TAR & TAR, OSJD 2 \\
\hline $\begin{array}{l}\text { Track gauge } \\
(\mathrm{mm})\end{array}$ & 1435 & 1520 & 1520 & 1520 & 1435 \\
\hline $\begin{array}{l}\text { Max permitted } \\
\text { axle load (tf) }\end{array}$ & 22.5 & - & 23.5 & $24^{13}$ & 23 \\
\hline $\begin{array}{l}\text { Max permitted } \\
\text { train length }(\mathrm{m})\end{array}$ & 750 & 1200 & 1300 & 850 & 850 \\
\hline Traction system & $3 \mathrm{kV} \mathrm{DC}$ & $\begin{array}{c}25 \mathrm{kV}-50 \\
\text { Hz system } \\
\text { AC Eastern } \\
\text { Ukraine and } \\
3 \mathrm{kV} \mathrm{DC} \\
\text { Western } \\
\text { Ukraine }\end{array}$ & $\begin{array}{c}3 \mathrm{kV} \mathrm{DC} \\
25 \mathrm{kV} \mathrm{AC} 50 \\
\mathrm{~Hz}\end{array}$ & Non-electrified & $\begin{array}{c}\text { Non- } \\
\text { electrified } \\
25 \mathrm{kV} \mathrm{AC} 50 \\
\mathrm{~Hz}\end{array}$ \\
\hline $\begin{array}{l}\text { Signaling } \\
\text { system }\end{array}$ & ERTMS & $\begin{array}{l}\text { Automatic } \\
\text { Block } \\
\text { Signaling }\end{array}$ & $\begin{array}{c}\text { Automatic } \\
\text { Block } \\
\text { Signaling }\end{array}$ & Lateral electric & $\begin{array}{l}\text { Lateral } \\
\text { electric }\end{array}$ \\
\hline $\begin{array}{l}\text { Track capacity: } \\
\text { number of } \\
\text { tracks }\end{array}$ & High & $\begin{array}{c}\text { Max. } 210 \\
\text { trains/day } \\
\text { (current } 160 \\
\text { trains/day) }\end{array}$ & High & Medium & Medium \\
\hline $\begin{array}{l}\text { Max speed of } \\
\text { freight trains } \\
\quad(\mathrm{km} / \mathrm{h})\end{array}$ & 100 & 90 & 90 & 60 & 90 \\
\hline $\begin{array}{l}\text { Max speed } \\
\text { of passenger } \\
\text { trains }(\mathrm{km} / \mathrm{h})\end{array}$ & 140 & 160 & 140 & 90 & 100 \\
\hline
\end{tabular}

${ }^{13}$ Same technical railway standards as Russia (Davydenko, Landa, Martens, Nesterova, and Wark, 2012, p.79)((PADECO Co., 2006, p. 38). 


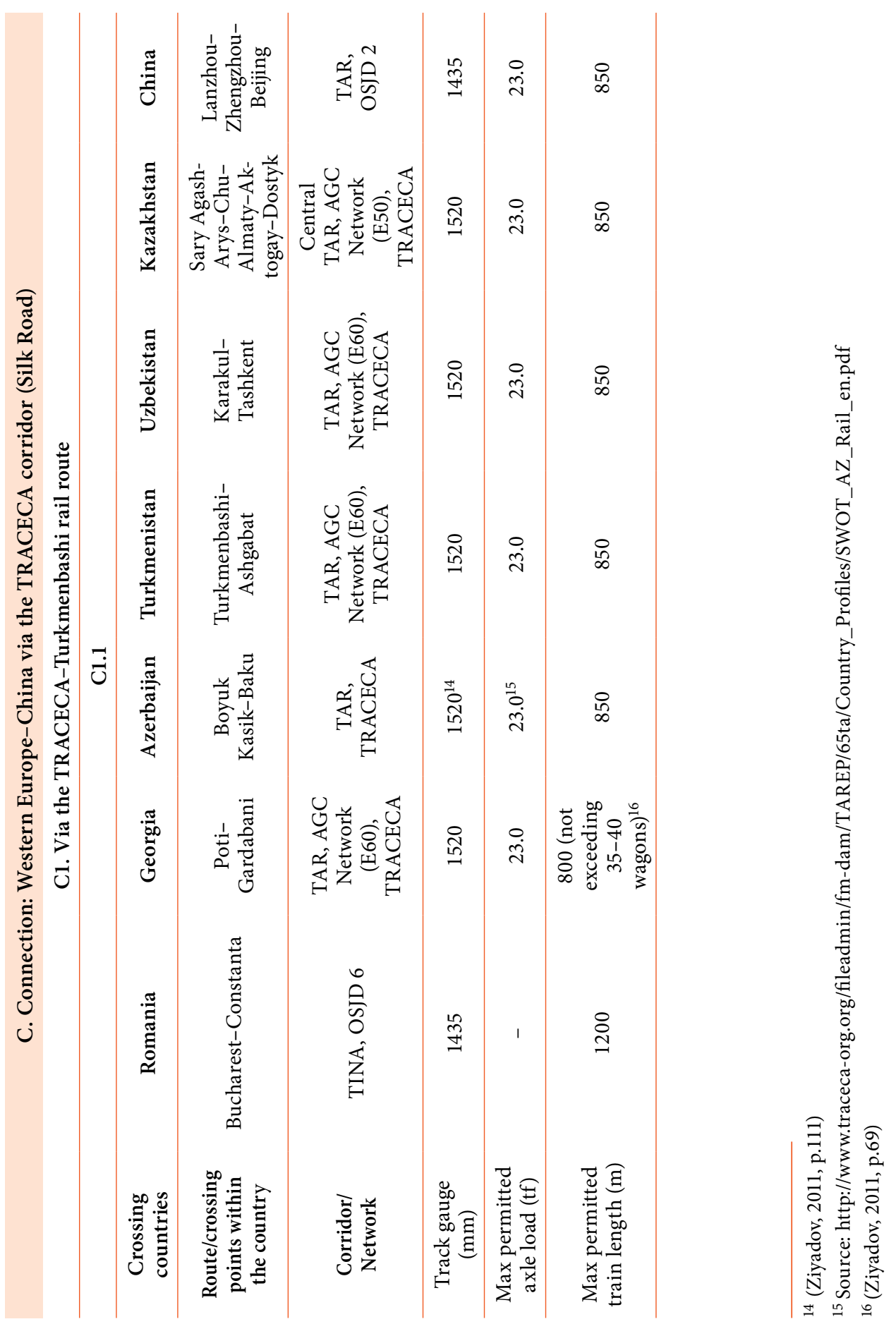




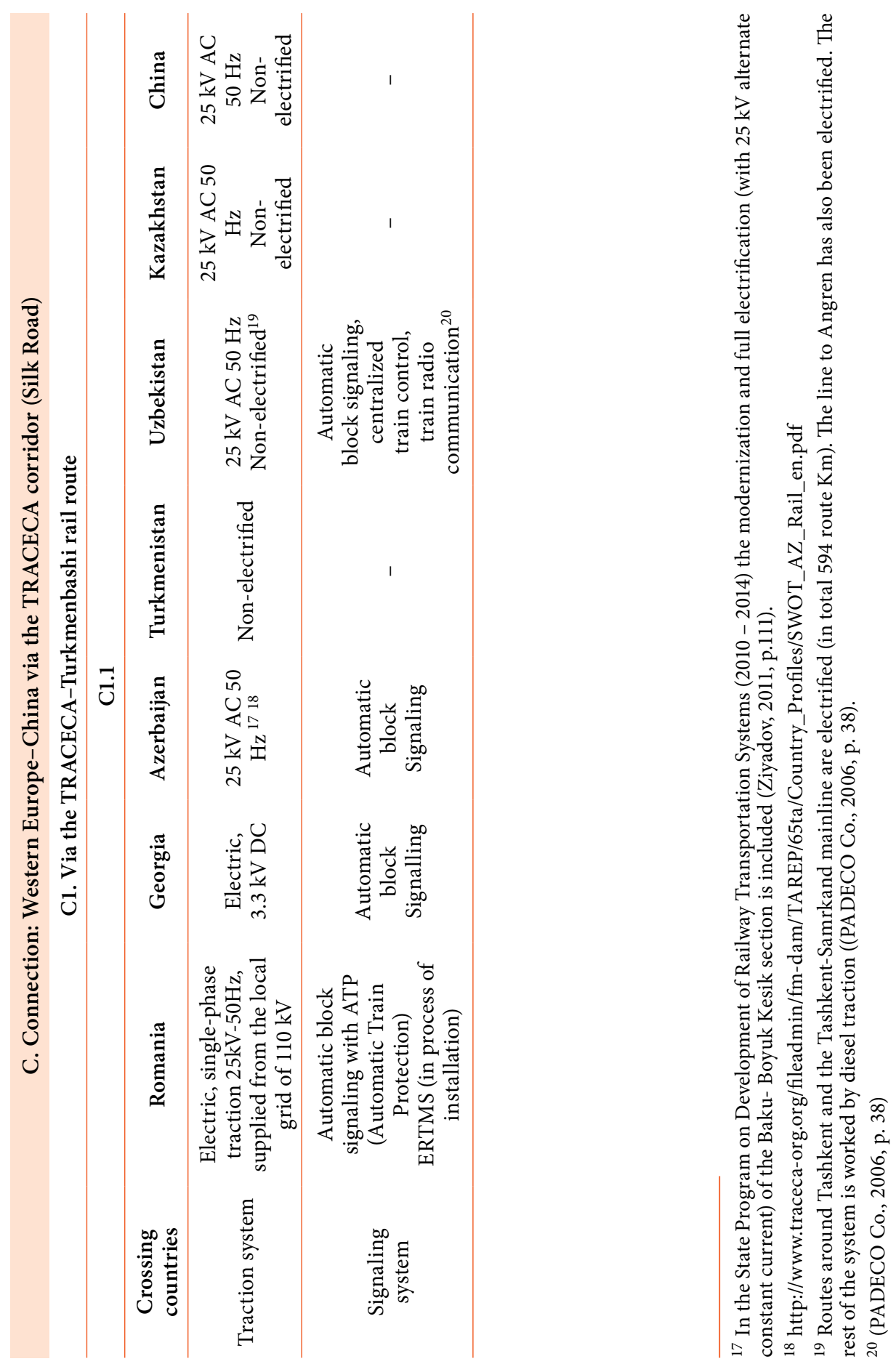




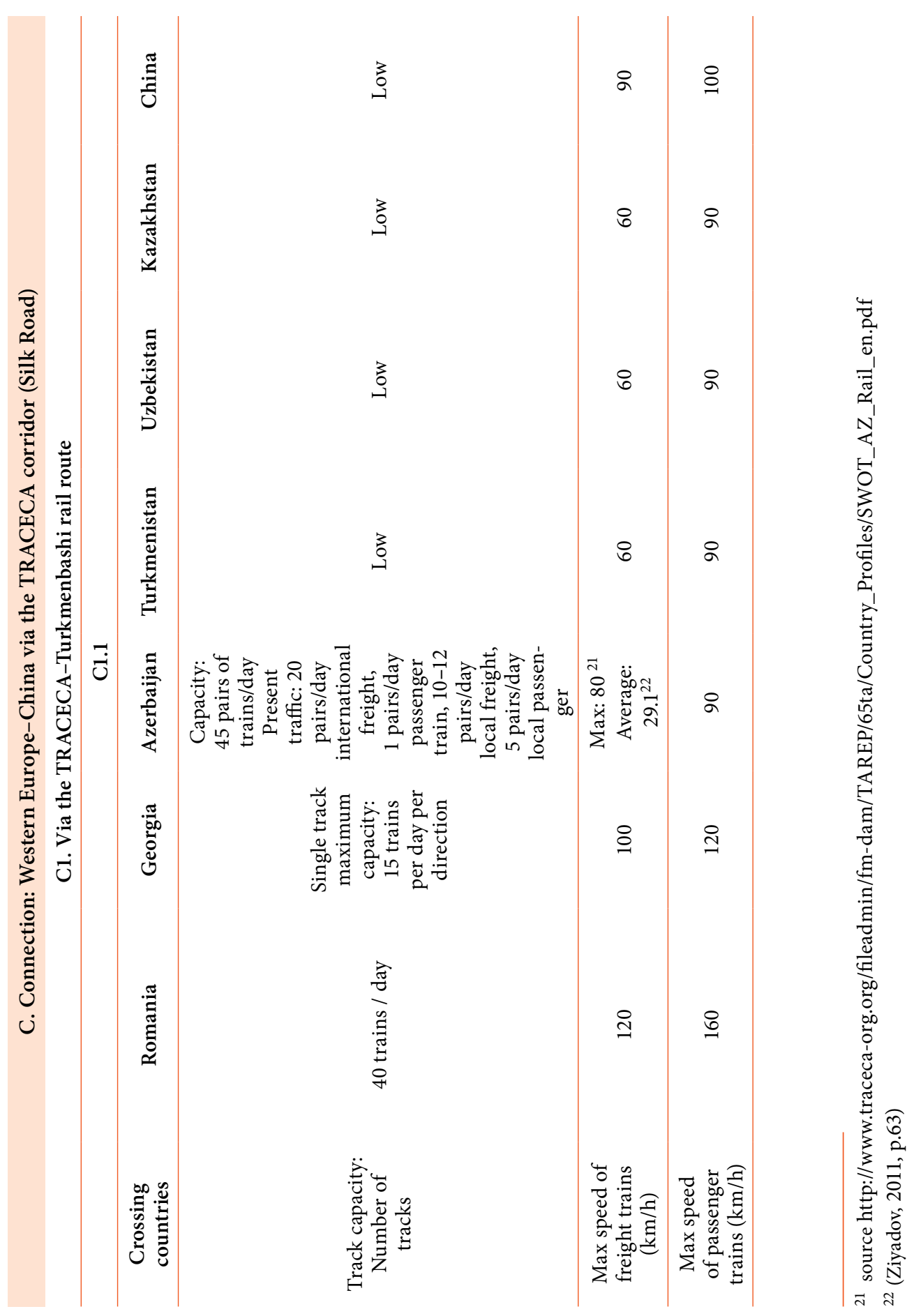




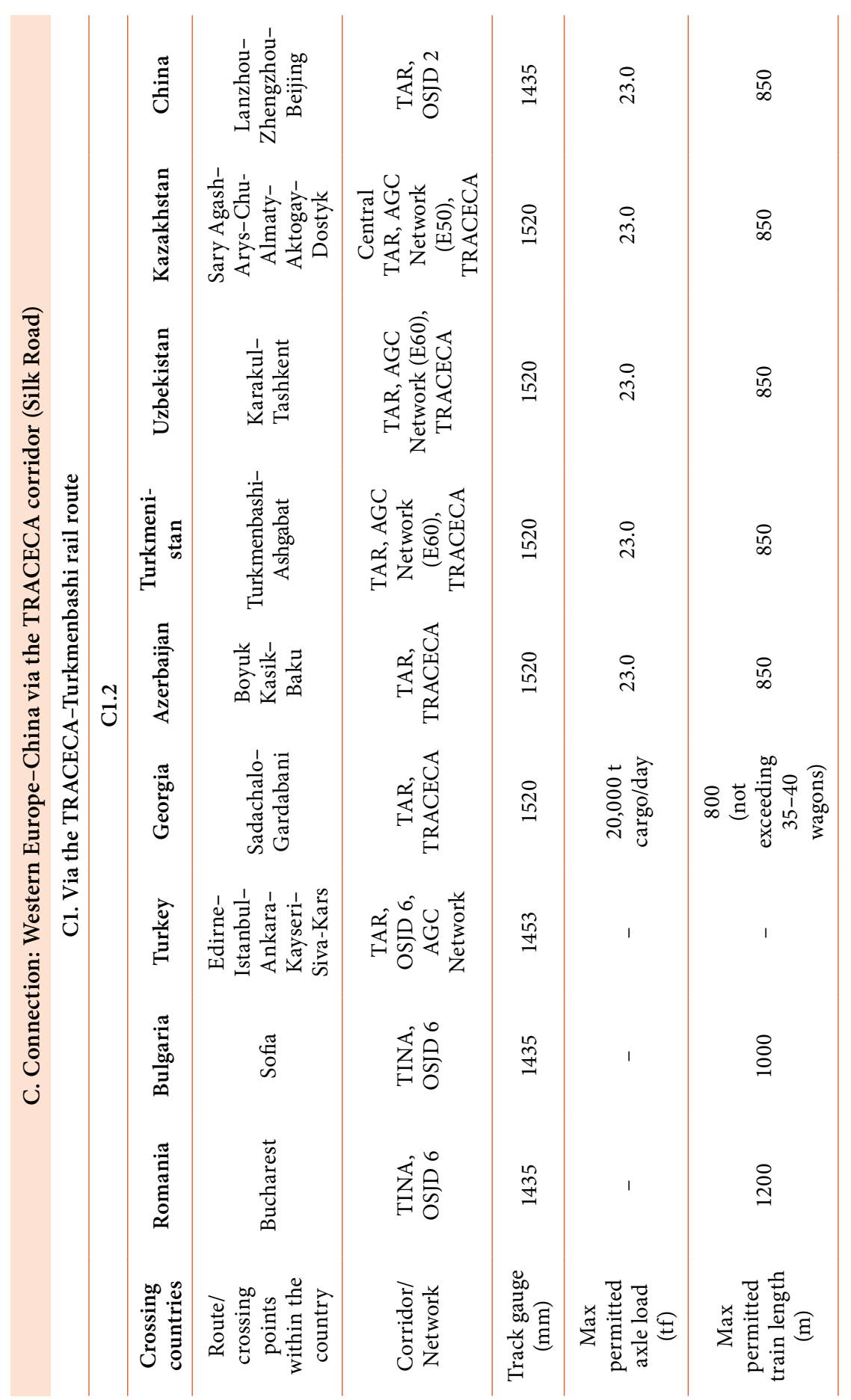




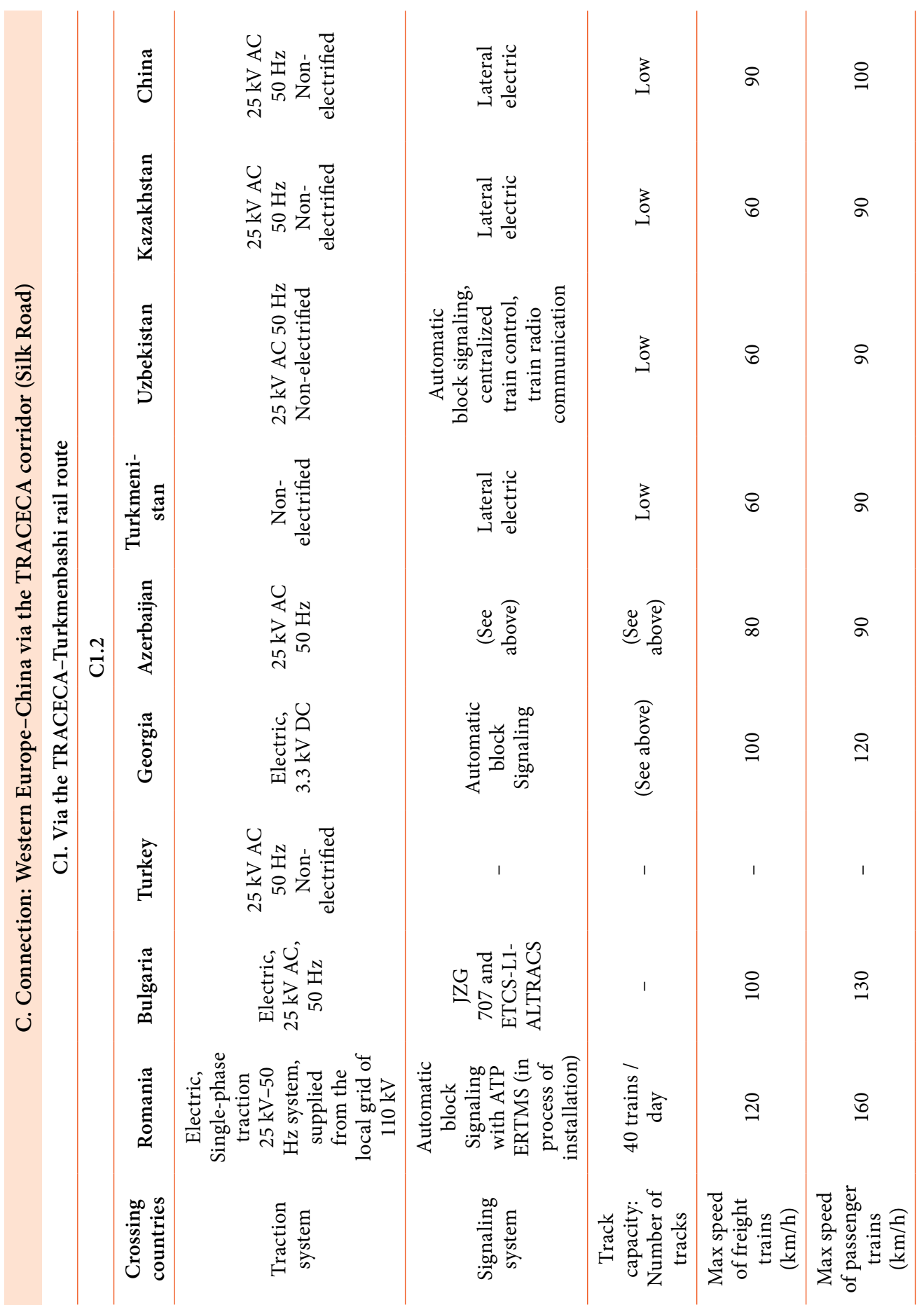




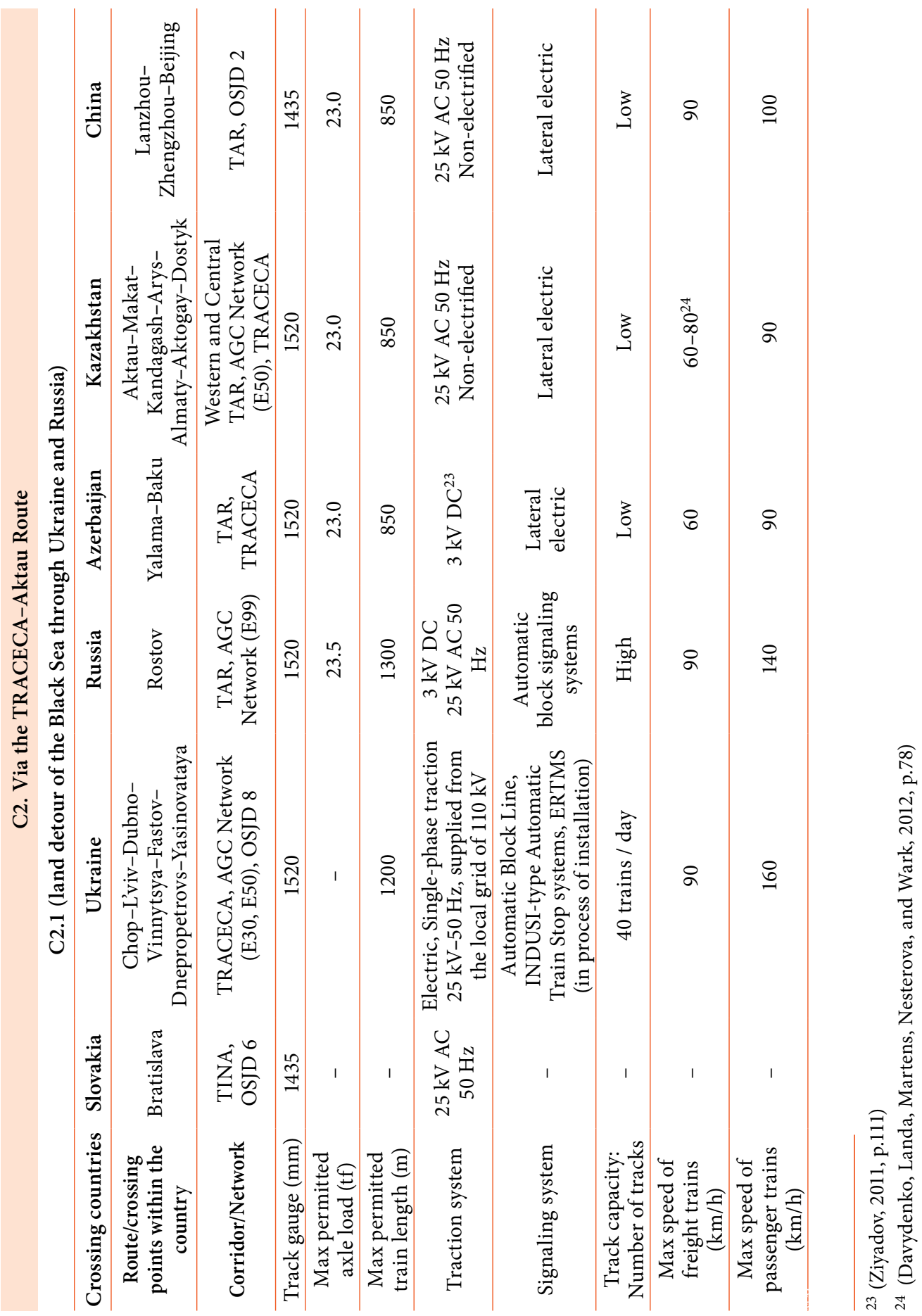




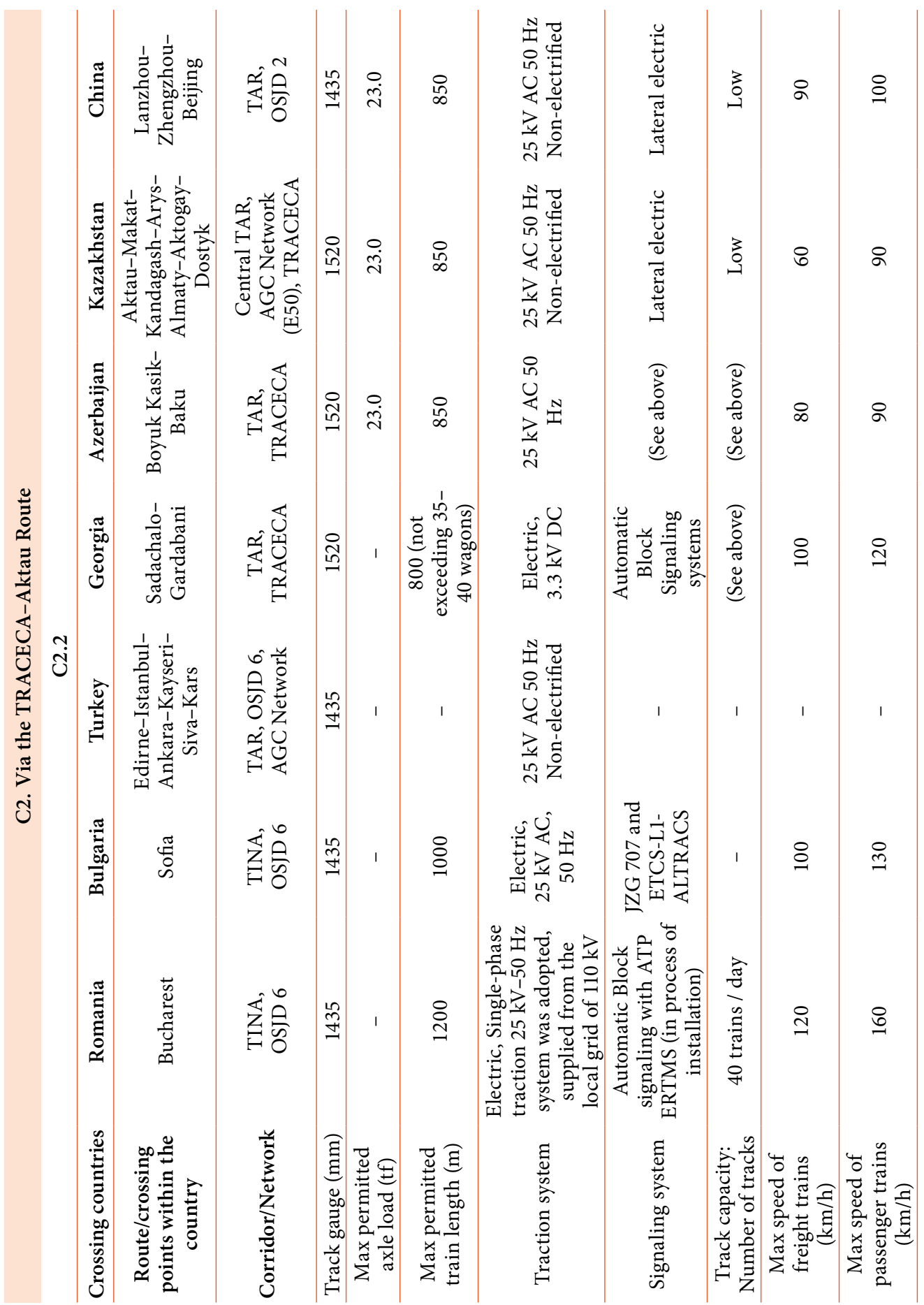




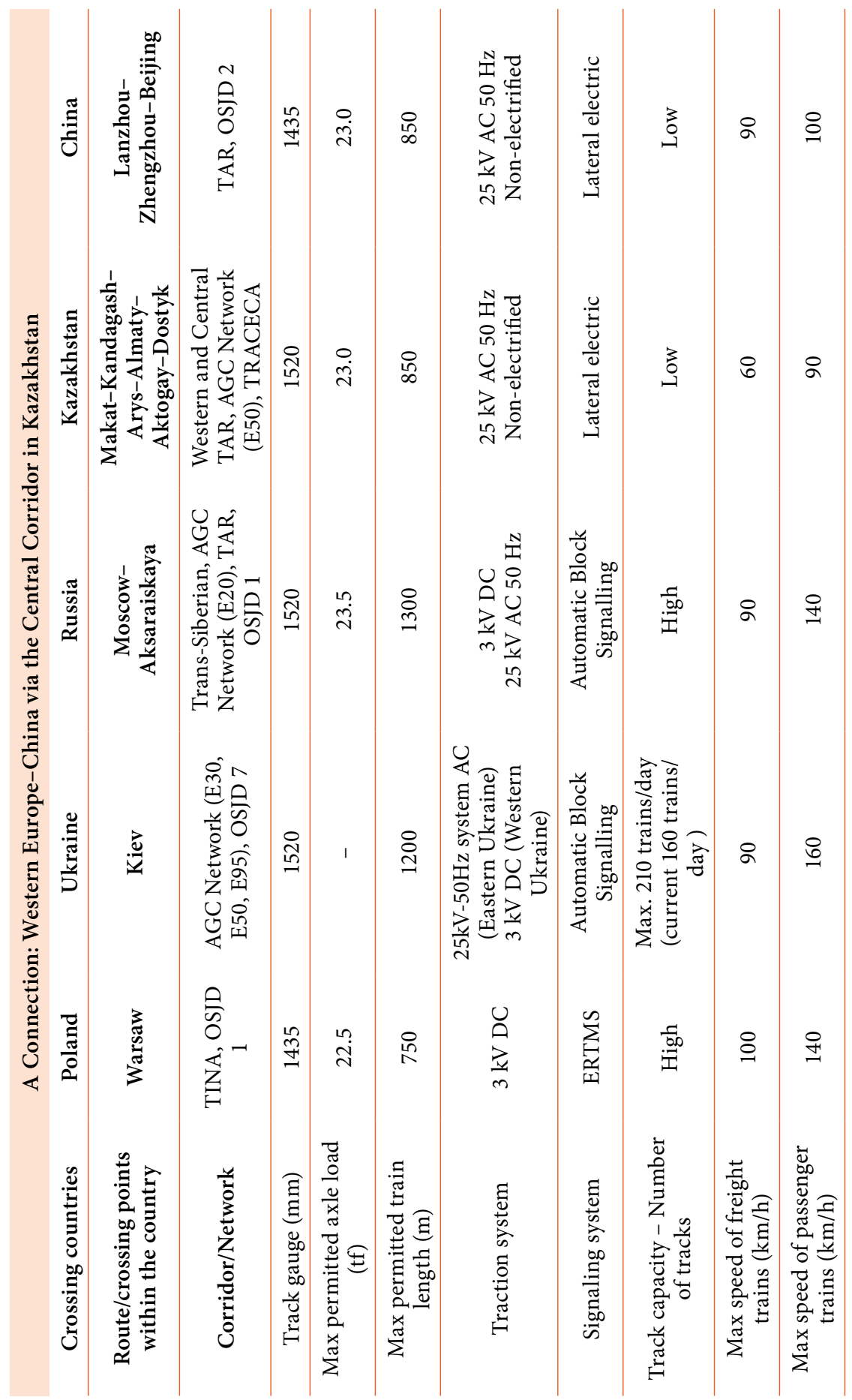




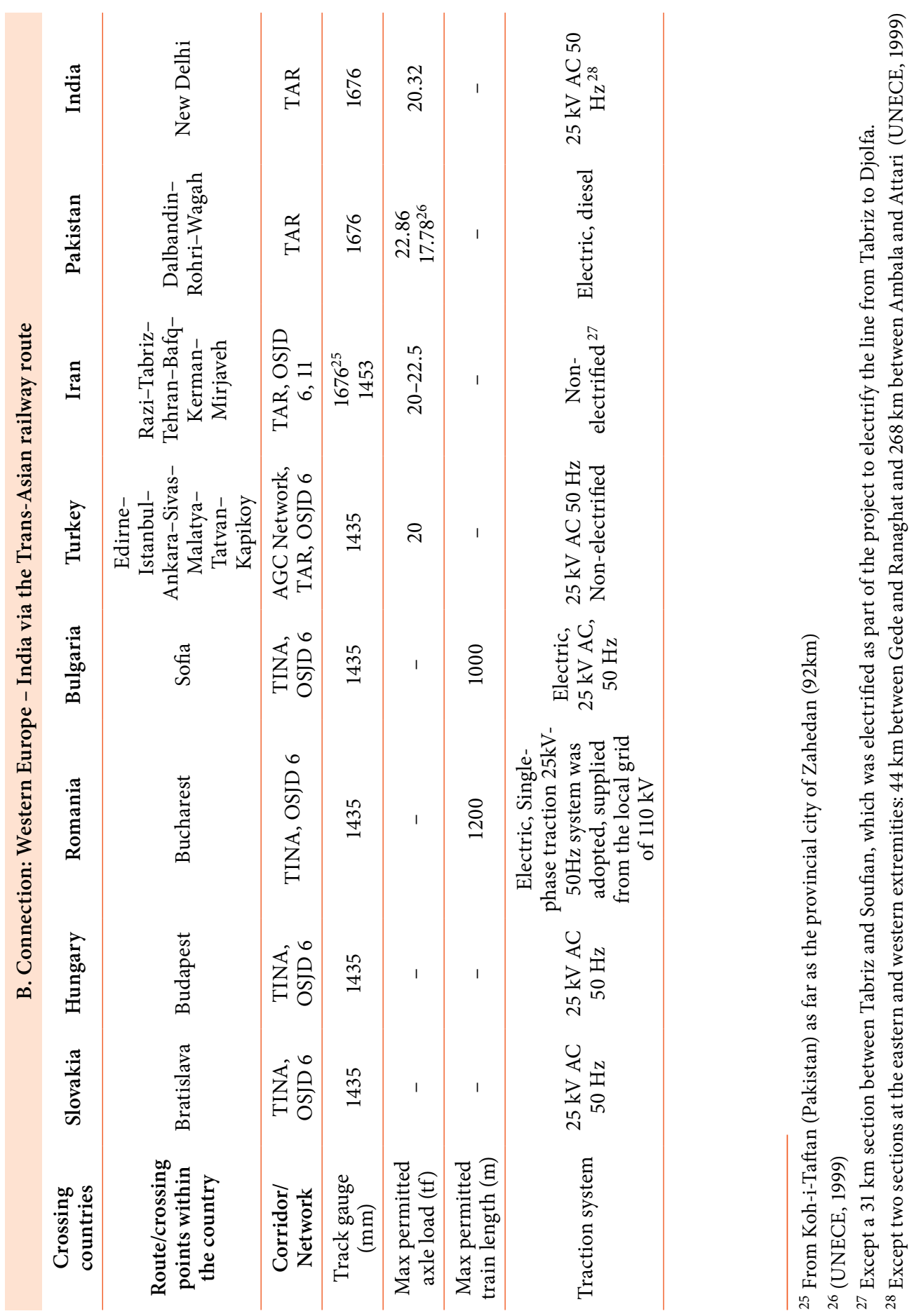




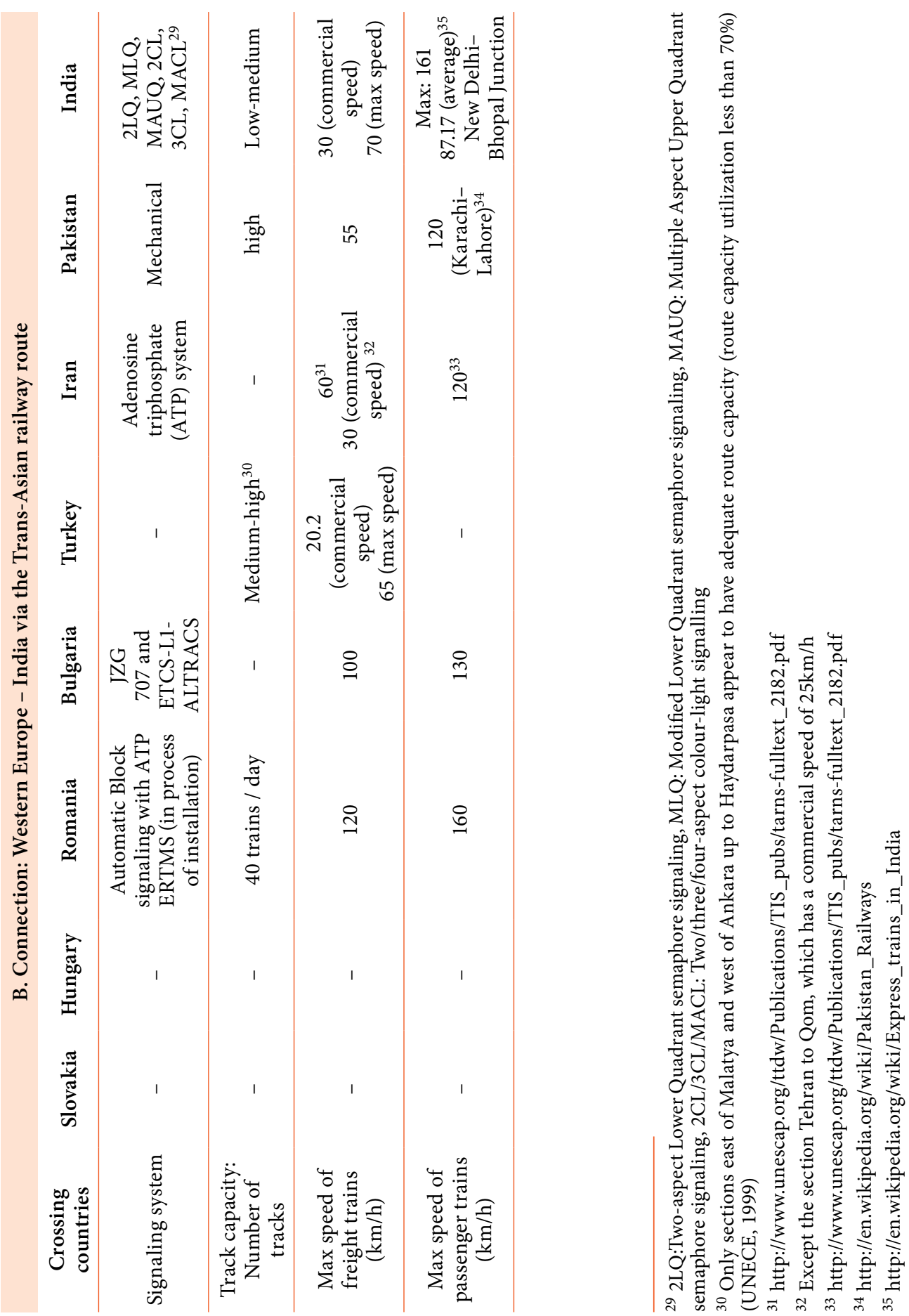


Additionally, Table 7 provides detailed information on the traction systems of the identified railway routes.

Table 7. Routes and stations with different types of traction within transport corridors

\section{A. Connection: Western Europe-Russian Far East-Japan}

A1. Via main Trans-Siberian railway network

\begin{tabular}{|c|c|c|c|}
\hline \multicolumn{4}{|c|}{ Crossing countries - Poland } \\
\hline Routes & Length $(\mathrm{km})$ & Types of traction & Remarks \\
\hline Warsaw-Krakow & 300 & $3 \mathrm{kV} \mathrm{DC}$ & - \\
\hline Krakow-Mostys'ka & 200 & $3 \mathrm{kV} \mathrm{DC}$ & $\begin{array}{c}\text { Track gauge changing on Mostys'ka } \\
\text { station (1435/1520); border between } \\
\text { Poland and Ukraine }\end{array}$ \\
\hline \multicolumn{4}{|c|}{ Crossing countries - Ukraine (or Belarus) } \\
\hline Mostys'ka-Lviv & 70 & $3 \mathrm{kV} \mathrm{DC}$ & $\begin{array}{c}\text { Changing types of traction on Lviv } \\
\text { station }\end{array}$ \\
\hline Lviv-Kyiv & 580 & $25 \mathrm{kV} \mathrm{AC} 50 \mathrm{~Hz}$ & - \\
\hline $\begin{array}{l}\text { Kyiv-Hutor- } \\
\text { Mikhailowsky }\end{array}$ & 340 & $25 \mathrm{kV} \mathrm{AC} 50 \mathrm{~Hz}$ & $\begin{array}{l}\text { Border between Ukraine and Belarus } \\
\text { on Hutor-Mikhailowsky station }\end{array}$ \\
\hline \multicolumn{4}{|c|}{ Crossing countries - Belarus (or Ukraine) } \\
\hline $\begin{array}{l}\text { Hutor- } \\
\text { Mikhailowsky- } \\
\text { Suhinichi }\end{array}$ & 250 & $25 \mathrm{kV} \mathrm{AC} 50 \mathrm{~Hz}$ & $\begin{array}{c}\text { Changing types of traction on } \\
\text { Suhinichi station. Border between } \\
\text { Belarus and Russia }\end{array}$ \\
\hline \multicolumn{4}{|c|}{ Crossing countries - Russia } \\
\hline Suhinichi-Moscow & 300 & $3 \mathrm{kV} \mathrm{DC}$ & - \\
\hline Moscow-Vladimir & 200 & $3 \mathrm{kV} \mathrm{DC}$ & $\begin{array}{c}\text { Changing types of traction on } \\
\text { Vladimir station }\end{array}$ \\
\hline Vladimir-Balezino & 1100 & $\begin{array}{l}25 \mathrm{kV} \mathrm{AC} \\
50 \mathrm{~Hz}\end{array}$ & $\begin{array}{c}\text { Changing types of traction on } \\
\text { Balezino station }\end{array}$ \\
\hline $\begin{array}{l}\text { Balezino-Perm- } \\
\text { Yekaterinburg }\end{array}$ & 450 & $3 \mathrm{kV} \mathrm{DC}$ & - \\
\hline $\begin{array}{l}\text { Yekaterinburg- } \\
\text { Omsk }\end{array}$ & 900 & $3 \mathrm{kV} \mathrm{DC}$ & - \\
\hline Omsk-Novosibirsk & 700 & $3 \mathrm{kV} \mathrm{DC}$ & - \\
\hline $\begin{array}{l}\text { Novosibirsk- } \\
\text { Mejdurechensk }\end{array}$ & 480 & $3 \mathrm{kV} \mathrm{DC}$ & $\begin{array}{l}\text { Changing types of traction on } \\
\text { Mejdurechensk station }\end{array}$ \\
\hline $\begin{array}{l}\text { Mejdurechensk- } \\
\text { Ulan Ude }\end{array}$ & 2400 & $\begin{array}{l}25 \mathrm{kV} \mathrm{AC} \\
50 \mathrm{~Hz}\end{array}$ & - \\
\hline $\begin{array}{l}\text { Ulan Ude- } \\
\text { Vladivostok }\end{array}$ & 4700 & $\begin{array}{l}25 \mathrm{kV} \mathrm{AC} \\
50 \mathrm{~Hz}\end{array}$ & - \\
\hline
\end{tabular}

Resume:

Total length railway corridors Al

$11000 \mathrm{~km}$

Types of traction

$3 \mathrm{kV} \mathrm{DC}$

$3600 \mathrm{~km} \mathrm{(32 \% )}$

$25 \mathrm{kV} \mathrm{AC} 50 \mathrm{~Hz}$

7400 km (68\%) 
B: Connection: Western Europe-China via the Trans-Siberian route and its branches

B1. Via branch of the Trans-Siberian railway network and the Manchurian Route

\begin{tabular}{|c|c|c|c|}
\hline \multicolumn{4}{|c|}{ Crossing countries - Poland } \\
\hline Routes & $\begin{array}{l}\text { Length } \\
(\mathrm{km})\end{array}$ & Types of traction & Remarks \\
\hline Warsaw-Krakow & 300 & $3 \mathrm{kV} \mathrm{DC}$ & - \\
\hline Krakow-Mostys'ka & 200 & $3 \mathrm{kV} \mathrm{DC}$ & $\begin{array}{c}\text { Track gauge changing } \\
\text { on Mostys'ka station } \\
(1435 / 1520) ; \text { border } \\
\text { between Poland and } \\
\text { Ukraine }\end{array}$ \\
\hline \multicolumn{4}{|c|}{ Crossing countries - Ukraine (or Belarus) } \\
\hline Mostys'ka-Lviv & 70 & $3 \mathrm{kV} \mathrm{DC}$ & $\begin{array}{l}\text { Changing types of } \\
\text { traction on Lviv station }\end{array}$ \\
\hline Lviv-Kyiv & 580 & $\begin{array}{c}25 \mathrm{kV} \mathrm{AC} \\
50 \mathrm{~Hz}\end{array}$ & - \\
\hline Kyiv-Hutor-Mikhailowsky & 340 & $\begin{array}{c}25 \mathrm{kV} \mathrm{AC} \\
50 \mathrm{~Hz}\end{array}$ & $\begin{array}{l}\text { Border between Ukraine } \\
\text { and Belarus on Hutor- } \\
\text { Mikhailowsky station }\end{array}$ \\
\hline \multicolumn{4}{|c|}{ Crossing countries - Belarus (or Ukraine) } \\
\hline $\begin{array}{l}\text { Hutor-Mikhailowsky- } \\
\text { Suhinichi }\end{array}$ & 250 & $\begin{array}{c}25 \mathrm{kV} \mathrm{AC} \\
50 \mathrm{~Hz}\end{array}$ & $\begin{array}{l}\text { Changing types of } \\
\text { traction on Suhinichi } \\
\text { station. Border between } \\
\text { Belarus and Russia }\end{array}$ \\
\hline \multicolumn{4}{|c|}{ Crossing countries - Russia } \\
\hline Suhinichi-Moscow & 300 & $3 \mathrm{kV} \mathrm{DC}$ & - \\
\hline Moscow-Vladimir & 200 & $3 \mathrm{kV} \mathrm{DC}$ & $\begin{array}{l}\text { Changing types of } \\
\text { traction on Vladimir } \\
\text { station }\end{array}$ \\
\hline Vladimir-Balezino & 1100 & $\begin{array}{c}25 \mathrm{kV} \mathrm{AC} \\
50 \mathrm{~Hz}\end{array}$ & $\begin{array}{l}\text { Changing types of } \\
\text { traction on Balezino } \\
\text { station }\end{array}$ \\
\hline Balezino-Perm-Yekaterinburg & 450 & $3 \mathrm{kV} \mathrm{DC}$ & - \\
\hline Yekaterinburg-Omsk & 900 & $3 \mathrm{kV} \mathrm{DC}$ & - \\
\hline Omsk-Novosibirsk & 700 & $3 \mathrm{kV} \mathrm{DC}$ & - \\
\hline Novosibirsk-Mejdurechensk & 480 & $3 \mathrm{kV} \mathrm{DC}$ & $\begin{array}{c}\text { Changing types } \\
\text { of traction on } \\
\text { Mejdurechensk station }\end{array}$ \\
\hline Mejdurechensk-Ulan Ude & 2400 & $\begin{array}{l}25 \mathrm{kV} \mathrm{AC} \\
50 \mathrm{~Hz}\end{array}$ & - \\
\hline Ulan Ude-Tarskay & 700 & $\begin{array}{c}25 \mathrm{kV} \mathrm{AC} \\
50 \mathrm{~Hz}\end{array}$ & - \\
\hline
\end{tabular}


B: Connection: Western Europe-China via the Trans-Siberian route and its branches

B1. Via branch of the Trans-Siberian railway network and the Manchurian Route

\begin{tabular}{|c|c|c|c|}
\hline Tarskay-Zabaikalsk & 450 & $3 \mathrm{kV} \mathrm{DC}$ & $\begin{array}{c}\text { Border between Russia } \\
\text { and China. }\end{array}$ \\
\hline \multicolumn{4}{|c|}{ Crossing countries - China } \\
\hline Manzhouli-Harbin & 1000 & Non-electrified & $\begin{array}{l}\text { Changing types of } \\
\text { traction on Manzhouli } \\
\text { station (diesel); track } \\
\text { gauge changing on } \\
\text { Manzhouli station } \\
(1520 / 1435 \mathrm{~mm})\end{array}$ \\
\hline Harbin-Shenyang & 550 & $\begin{array}{c}25 \mathrm{kV} \mathrm{AC} \\
50 \mathrm{~Hz}\end{array}$ & $\begin{array}{c}\text { Changing types of } \\
\text { traction on Harbin } \\
\text { station }\end{array}$ \\
\hline Shenyang-Beijing & 700 & $\begin{array}{c}25 \mathrm{kV} \mathrm{AC} \\
50 \mathrm{~Hz}\end{array}$ & - \\
\hline \multicolumn{4}{|c|}{ Resume: } \\
\hline \multicolumn{3}{|c|}{ Total length railway corridors B1 } & $11670 \mathrm{~km}$ \\
\hline \multicolumn{4}{|c|}{ Types of traction } \\
\hline \multicolumn{3}{|c|}{$3 \mathrm{kV} \mathrm{DC}$} & 4050 km (34\%) \\
\hline \multicolumn{3}{|c|}{$25 \mathrm{kV} \mathrm{AC} 50 \mathrm{~Hz}$} & $6620 \mathrm{~km}(56 \%)$ \\
\hline \multicolumn{3}{|c|}{ Non-electrified } & 1000 km (10\%) \\
\hline
\end{tabular}

B: Connection: Western Europe-China via the Trans-Siberian route and its branches

B2. Via branch of the Trans-Siberian railway network and the Trans Kazakh Route

\begin{tabular}{|c|c|c|c|}
\hline \multicolumn{4}{|c|}{ Crossing countries - Poland } \\
\hline Routes & $\begin{array}{c}\text { Length } \\
(\mathrm{km})\end{array}$ & Types of traction & Remarks \\
\hline Warsaw-Krakow & 300 & $3 \mathrm{kV} \mathrm{DC}$ & - \\
\hline Krakow-Mostys'ka & 200 & $3 \mathrm{kV} \mathrm{DC}$ & $\begin{array}{c}\text { Track gauge changing } \\
\text { on Mostys'ka station } \\
\text { (1435/1520mm); border } \\
\text { between Poland and } \\
\text { Ukraine }\end{array}$ \\
\hline \multicolumn{4}{|c|}{ Crossing countries - Ukraine (or Belarus) } \\
\hline Mostys'ka-Lviv & 70 & $3 \mathrm{kV} \mathrm{DC}$ & $\begin{array}{l}\text { Changing types of } \\
\text { traction on Lviv station }\end{array}$ \\
\hline Lviv-Kyiv & 580 & $\begin{array}{c}25 \mathrm{kV} \mathrm{AC} \\
50 \mathrm{~Hz}\end{array}$ & - \\
\hline Kyiv-Hutor-Mikhailowsky & 340 & $\begin{array}{c}25 \mathrm{kV} \mathrm{AC} \\
50 \mathrm{~Hz}\end{array}$ & $\begin{array}{l}\text { Border between Ukraine } \\
\text { and Belarus on Hutor- } \\
\text { Mikhailowsky station }\end{array}$ \\
\hline
\end{tabular}


B: Connection: Western Europe-China via the Trans-Siberian route and its branches

B2. Via branch of the Trans-Siberian railway network and the Trans Kazakh Route Crossing countries - Belarus (or Ukraine)

\begin{tabular}{|c|c|c|c|}
\hline $\begin{array}{l}\text { Hutor-Mikhailowsky- } \\
\text { Suhinichi }\end{array}$ & 250 & $\begin{array}{l}25 \mathrm{kV} \mathrm{AC} \\
50 \mathrm{~Hz}\end{array}$ & $\begin{array}{c}\text { Changing types of } \\
\text { traction on Suhinichi } \\
\text { station; border between } \\
\text { Belarus and Russia }\end{array}$ \\
\hline \multicolumn{4}{|c|}{ Crossing countries - Russia } \\
\hline Suhinichi-Moscow & 300 & $3 \mathrm{kV} \mathrm{DC}$ & - \\
\hline Moscow-Vladimir & 200 & $3 \mathrm{kV} \mathrm{DC}$ & $\begin{array}{l}\text { Changing types of } \\
\text { traction on Vladimir } \\
\text { station }\end{array}$ \\
\hline Vladimir-Balezino & 1100 & $\begin{array}{l}25 \mathrm{kV} \mathrm{AC} \\
50 \mathrm{~Hz}\end{array}$ & $\begin{array}{l}\text { Changing types of } \\
\text { traction on Balezino } \\
\text { station }\end{array}$ \\
\hline Balezino-Perm-Yekaterinburg & 450 & $3 \mathrm{kV} \mathrm{DC}$ & - \\
\hline $\begin{array}{l}\text { Yekaterinburg-Presnogorkovka } \\
\text { (through Kurgan) }\end{array}$ & 400 & $3 \mathrm{kV} \mathrm{DC}$ & $\begin{array}{l}\text { Changing types } \\
\text { of traction on } \\
\text { Presnogorkovka station; } \\
\text { border between Russia } \\
\text { and Kazakhstan }\end{array}$ \\
\hline \multicolumn{4}{|c|}{ Crossing countries - Kazakhstan } \\
\hline $\begin{array}{c}\text { Presnogorkovka-Moyinty } \\
\text { (through Astana) }\end{array}$ & 1200 & $\begin{array}{l}25 \mathrm{kV} \mathrm{AC} \\
50 \mathrm{~Hz}\end{array}$ & $\begin{array}{l}\text { Changing types of } \\
\text { traction on Moyinty } \\
\text { station. }\end{array}$ \\
\hline $\begin{array}{c}\text { Moyinty-Dostyk (through } \\
\text { Aqtoghay) }\end{array}$ & 850 & Non-electrified & $\begin{array}{c}\text { Border between } \\
\text { Kazakhstan (Dostyk) } \\
\text { and China (Alashankou) }\end{array}$ \\
\hline \multicolumn{4}{|c|}{ Crossing countries - China } \\
\hline Alashankou-Wuwei & 2000 & Non-electrified & $\begin{array}{l}\text { Changing types of } \\
\text { traction on Wuwei } \\
\text { station; track } \\
\text { gauge changing on } \\
\text { Alashankou station } \\
(1520 / 1435 \mathrm{~mm})\end{array}$ \\
\hline Wuwei-Lanzhou & 300 & $\begin{array}{c}25 \mathrm{kV} \mathrm{AC} \\
50 \mathrm{~Hz}\end{array}$ & - \\
\hline Lanzhou-Zhengzhou & 1200 & $\begin{array}{l}25 \mathrm{kV} \mathrm{AC} \\
50 \mathrm{~Hz}\end{array}$ & - \\
\hline Zhengzhou-Beijing & 700 & $\begin{array}{l}25 \mathrm{kV} \mathrm{AC} \\
50 \mathrm{~Hz}\end{array}$ & \\
\hline \multicolumn{4}{|c|}{ Resume: } \\
\hline Total length $r$ & ay corr & & $10440 \mathrm{~km}$ \\
\hline \multicolumn{4}{|c|}{ Types of traction } \\
\hline & DC & & 1920 km (18\%) \\
\hline $25 \mathrm{kV}$ & $50 \mathrm{~Hz}$ & & $5670 \mathrm{~km} \mathrm{(54 \% )}$ \\
\hline Non- & trified & & $2850 \mathrm{~km} \mathrm{(28 \% )}$ \\
\hline
\end{tabular}


B: Connection: Western Europe-China via the Trans-Siberian route and its branches

B3. Via branch of the Trans-Siberian railway network and the Mongolian Route

\begin{tabular}{|c|c|c|c|}
\hline \multicolumn{4}{|c|}{ Crossing countries - Poland } \\
\hline Routes & $\begin{array}{l}\text { Length } \\
(\mathrm{km})\end{array}$ & Types of traction & Remarks \\
\hline Warsaw-Krakow & 300 & $3 \mathrm{kV} \mathrm{DC}$ & \\
\hline Krakow-Mostys'ka & 200 & $3 \mathrm{kV} \mathrm{DC}$ & $\begin{array}{c}\text { Track gauge changing } \\
\text { on Mostys'ka station } \\
(1435 / 1520 \mathrm{~mm}) \text {; border } \\
\text { between Poland and } \\
\text { Ukraine }\end{array}$ \\
\hline \multicolumn{4}{|c|}{ Crossing countries - Ukraine (or Belarus) } \\
\hline Mostys'ka-Lviv & 70 & $3 \mathrm{kV} \mathrm{DC}$ & $\begin{array}{l}\text { Changing types of } \\
\text { traction on Lviv station }\end{array}$ \\
\hline Lviv-Kyiv & 580 & $\begin{array}{c}25 \mathrm{kV} \mathrm{AC} \\
50 \mathrm{~Hz}\end{array}$ & - \\
\hline Kyiv-Hutor-Mikhailowsky & 340 & $\begin{array}{c}25 \mathrm{kV} \mathrm{AC} \\
50 \mathrm{~Hz}\end{array}$ & $\begin{array}{l}\text { Border between Ukraine } \\
\text { and Belarus on Hutor- } \\
\text { Mikhailowsky station }\end{array}$ \\
\hline \multicolumn{4}{|c|}{ Crossing countries - Belarus (or Ukraine) } \\
\hline $\begin{array}{l}\text { Hutor-Mikhailowsky- } \\
\text { Suhinichi }\end{array}$ & 250 & $\begin{array}{c}25 \mathrm{kV} \mathrm{AC} \\
50 \mathrm{~Hz}\end{array}$ & $\begin{array}{l}\text { Changing types of } \\
\text { traction on Suhinichi } \\
\text { station; border between } \\
\text { Belarus and Russia }\end{array}$ \\
\hline \multicolumn{4}{|c|}{ Crossing countries - Russia } \\
\hline Suhinichi-Moscow & 300 & $3 \mathrm{kV} \mathrm{DC}$ & - \\
\hline Moscow-Vladimir & 200 & $3 \mathrm{kV} \mathrm{DC}$ & $\begin{array}{l}\text { Changing types of } \\
\text { traction on Vladimir } \\
\text { station }\end{array}$ \\
\hline Vladimir-Balezino & 1100 & $\begin{array}{c}25 \mathrm{kV} \mathrm{AC} \\
50 \mathrm{~Hz}\end{array}$ & $\begin{array}{c}\text { Changing types of } \\
\text { traction on Balezino } \\
\text { station }\end{array}$ \\
\hline $\begin{array}{l}\text { Balezino-Perm - } \\
\text { Yekaterinburg }\end{array}$ & 450 & $3 \mathrm{kV} \mathrm{DC}$ & - \\
\hline Yekaterinburg-Omsk & 900 & $3 \mathrm{kV} \mathrm{DC}$ & - \\
\hline Omsk-Novosibirsk & 700 & $3 \mathrm{kV} \mathrm{DC}$ & - \\
\hline Novosibirsk-Mejdurechensk & 480 & $3 \mathrm{kV} \mathrm{DC}$ & $\begin{array}{c}\text { Changing types } \\
\text { of traction on } \\
\text { Mejdurechensk station }\end{array}$ \\
\hline Mejdurechensk-Ulan Ude & 2400 & $\begin{array}{c}25 \mathrm{kV} \mathrm{AC} \\
50 \mathrm{~Hz}\end{array}$ & $\begin{array}{l}\text { Changing types of } \\
\text { traction on Ulan Ude } \\
\text { station (diesel) }\end{array}$ \\
\hline
\end{tabular}


B: Connection: Western Europe-China via the Trans-Siberian route and its branches B3. Via branch of the Trans-Siberian railway network and the Mongolian Route

Ulan Ude-Naushki $250 \quad$ Non-electrified $\quad \begin{gathered}\text { Border between Russia } \\ \text { and Mongolia }\end{gathered}$

\section{Crossing countries - Mongolia}

\begin{tabular}{|c|c|c|c|}
\hline $\begin{array}{l}\text { Darhan-Ulan Bator-Zamyn- } \\
\text { Uud }\end{array}$ & 2200 & Non-electrified & $\begin{array}{c}\text { Border between } \\
\text { Mongolia and China; } \\
\text { track gauge changing } \\
\text { on Zamyn-Uud station } \\
(1520 / 1435 \mathrm{~mm})\end{array}$ \\
\hline \multicolumn{4}{|c|}{ Crossing countries - China } \\
\hline Erenhot-Jining & 340 & Non-electrified & $\begin{array}{l}\text { Changing types of } \\
\text { traction on Jining } \\
\text { station }\end{array}$ \\
\hline Jining-Beijing & 500 & $\begin{array}{c}25 \mathrm{kV} \mathrm{AC} \\
50 \mathrm{~Hz}\end{array}$ & - \\
\hline \multicolumn{4}{|c|}{ Resume: } \\
\hline \multicolumn{3}{|c|}{ Total length railway corridors B3 } & $11560 \mathrm{~km}$ \\
\hline \multicolumn{4}{|c|}{ Types of traction } \\
\hline \multicolumn{3}{|c|}{$3 \mathrm{kV} \mathrm{DC}$} & 3600 km (31\%) \\
\hline \multicolumn{3}{|c|}{$25 \mathrm{kV} \mathrm{AC} 50 \mathrm{~Hz}$} & $5170 \mathrm{~km}(44 \%)$ \\
\hline \multicolumn{3}{|c|}{ Non-electrified } & 2790 km (24\%) \\
\hline
\end{tabular}

C. Connection: Western Europe-China via the TRACECA corridor (Silk Road)

C1. Via the TRACECA-Turkmenbashi rail route

C1.1

\begin{tabular}{|c|c|c|c|}
\hline \multicolumn{4}{|c|}{ Crossing countries - Slovakia } \\
\hline Routes & $\begin{array}{c}\text { Length } \\
(\mathrm{km})\end{array}$ & $\begin{array}{l}\text { Types of } \\
\text { traction }\end{array}$ & Remarks \\
\hline Bratislava-Štúrovo & 150 & $\begin{array}{l}25 \mathrm{kV} \mathrm{AC} \\
50 \mathrm{~Hz}\end{array}$ & $\begin{array}{c}\text { Track gauge } 1435 \mathrm{~mm} ; \\
\text { border between Slovakia (Štúrovo) and } \\
\text { Hungary (Szob) }\end{array}$ \\
\hline \multicolumn{4}{|c|}{ Crossing countries - Hungary } \\
\hline Szob-Budapest & 50 & $\begin{array}{c}25 \mathrm{kV} \mathrm{AC} \\
50 \mathrm{~Hz}\end{array}$ & - \\
\hline Budapest-Lőkösháza & 250 & $\begin{array}{l}25 \mathrm{kV} \mathrm{AC} \\
50 \mathrm{~Hz}\end{array}$ & $\begin{array}{l}\text { Border between Hungary (Lőkösháza) } \\
\text { and Romania (Curtici) }\end{array}$ \\
\hline \multicolumn{4}{|c|}{ Crossing countries - Romania } \\
\hline Curtici-Bucharest & 650 & $\begin{array}{c}25 \mathrm{kV} \mathrm{AC} \\
50 \mathrm{~Hz}\end{array}$ & - \\
\hline Bucharest-Constanta & 250 & $\begin{array}{c}25 \mathrm{kV} \mathrm{AC} \\
50 \mathrm{~Hz}\end{array}$ & - \\
\hline
\end{tabular}


C. Connection: Western Europe-China via the TRACECA corridor (Silk Road)

C1. Via the TRACECA-Turkmenbashi rail route

C1.1

Black sea

\begin{tabular}{|c|c|c|c|}
\hline Constanta-Poti & 1000 & water route & - \\
\hline \multicolumn{4}{|c|}{ Crossing countries - Georgia } \\
\hline Poti-Gardabani & 370 & $3 \mathrm{kV} \mathrm{DC}$ & $\begin{array}{c}\text { Track gauge } 1520 \mathrm{~mm} \text {; } \\
\text { border between Georgia (Gardabani) and } \\
\text { Azerbaijan (Boyuk Kasik) }\end{array}$ \\
\hline \multicolumn{4}{|c|}{ Crossing countries - Azerbaijan } \\
\hline Boyuk Kasik-Baku & 500 & $3 \mathrm{kV} \mathrm{DC}$ & - \\
\hline \multicolumn{4}{|c|}{ Caspian Sea } \\
\hline Baku-Turkmenbashy & 270 & water route & - \\
\hline \multicolumn{4}{|c|}{ Crossing countries - Turkmenistan } \\
\hline $\begin{array}{l}\text { Turkmenbashi-Farap } \\
\text { (via Turkmenabad) }\end{array}$ & 1120 & $\begin{array}{l}\text { Non- } \\
\text { electrified }\end{array}$ & $\begin{array}{l}\text { Border between Turkmenistan (Farap) } \\
\text { and Uzbekistan (Khodza Davlet) }\end{array}$ \\
\hline \multicolumn{4}{|c|}{ Crossing countries - Uzbekistan } \\
\hline $\begin{array}{l}\text { Khodza Davlet- } \\
\text { Marokand }\end{array}$ & 330 & $\begin{array}{c}\text { Non- } \\
\text { electrified }\end{array}$ & $\begin{array}{c}\text { Changing types of traction on Marokand } \\
\text { station }\end{array}$ \\
\hline Marokand-Keles & 400 & $\begin{array}{l}25 \mathrm{kV} \mathrm{AC} \\
50 \mathrm{~Hz}\end{array}$ & $\begin{array}{c}\text { Border between Uzbekistan (Keles) and } \\
\text { Kazakhstan (Sary Agash) }\end{array}$ \\
\hline \multicolumn{4}{|c|}{ Crossing countries - Kazakhstan } \\
\hline Sary Agash-Almaty & 950 & $\begin{array}{l}25 \mathrm{kV} \mathrm{AC} \\
50 \mathrm{~Hz}\end{array}$ & $\begin{array}{l}\text { Changing types of traction on Almaty } \\
\text { station (diesel) }\end{array}$ \\
\hline Almaty-Dostyk & 870 & $\begin{array}{c}\text { Non- } \\
\text { electrified }\end{array}$ & $\begin{array}{l}\text { Border between Kazakhstan (Dostyk) and } \\
\text { China (Alashankou) }\end{array}$ \\
\hline \multicolumn{4}{|c|}{ Crossing countries - China } \\
\hline Alashankou-Wuwei & 2000 & $\begin{array}{c}\text { Non- } \\
\text { electrified }\end{array}$ & $\begin{array}{l}\text { Changing types of traction on Wuwei } \\
\text { station; track gauge changing on } \\
\text { Alashankou station }(1520 / 1435 \mathrm{~mm})\end{array}$ \\
\hline Wuwei-Lanzhou & 300 & $\begin{array}{l}25 \mathrm{kV} \mathrm{AC} \\
50 \mathrm{~Hz}\end{array}$ & - \\
\hline Lanzhou-Zhengzhou & 1200 & $\begin{array}{l}25 \mathrm{kV} \mathrm{AC} \\
50 \mathrm{~Hz}\end{array}$ & - \\
\hline Zhengzhou-Beijing & 700 & $\begin{array}{l}25 \mathrm{kV} \mathrm{AC} \\
50 \mathrm{~Hz}\end{array}$ & - \\
\hline \multicolumn{3}{|c|}{ Total length railway corridors $\mathrm{C} 1.1$} & $11360 \mathrm{~km}$ \\
\hline \multicolumn{4}{|c|}{ Types of traction } \\
\hline \multicolumn{3}{|c|}{$3 \mathrm{kV} \mathrm{DC}$} & $870 \mathrm{~km}(8 \%)$ \\
\hline \multicolumn{3}{|c|}{$25 \mathrm{kV}$ AC $50 \mathrm{~Hz}$} & 4900 km (43\%) \\
\hline \multicolumn{3}{|c|}{ Non-electrified } & $4320 \mathrm{~km}(38 \%)$ \\
\hline \multicolumn{3}{|c|}{ Water route } & 1270 km (11\%) \\
\hline
\end{tabular}


C. Connection: Western Europe-China via the TRACECA corridor (Silk Road)

C1. Via the TRACECA-Turkmenbashi rail route

C1.2

\begin{tabular}{|c|c|c|c|}
\hline \multicolumn{4}{|c|}{ Crossing countries - Slovakia } \\
\hline Routes & $\begin{array}{l}\text { Length } \\
(\mathrm{km})\end{array}$ & $\begin{array}{l}\text { Types of } \\
\text { traction }\end{array}$ & Remarks \\
\hline Bratislava-Štúrovo & 150 & $\begin{array}{l}25 \mathrm{kV} \mathrm{AC} \\
50 \mathrm{~Hz}\end{array}$ & $\begin{array}{c}\text { Track gauge } 1435 \mathrm{~mm} ; \\
\text { border between Slovakia (Štúrovo) and } \\
\text { Hungary (Szob) }\end{array}$ \\
\hline \multicolumn{4}{|c|}{ Crossing countries - Hungary } \\
\hline Szob-Budapest & 50 & $\begin{array}{l}25 \mathrm{kV} \mathrm{AC} \\
50 \mathrm{~Hz}\end{array}$ & - \\
\hline Budapest-Lőkösháza & 250 & $\begin{array}{l}25 \mathrm{kV} \mathrm{AC} \\
50 \mathrm{~Hz}\end{array}$ & $\begin{array}{c}\text { Border between Hungary (Lőkösháza) and } \\
\text { Romania (Curtici) }\end{array}$ \\
\hline \multicolumn{4}{|c|}{ Crossing countries - Romania } \\
\hline Curtici-Bucharest & 650 & $\begin{array}{l}25 \mathrm{kV} \mathrm{AC} \\
50 \mathrm{~Hz}\end{array}$ & $\begin{array}{l}\text { Changing types of traction on Bucharest } \\
\text { station (diesel) }\end{array}$ \\
\hline Bucharest-Giurgiu & 90 & $\begin{array}{l}\text { Non- } \\
\text { electrified }\end{array}$ & $\begin{array}{c}\text { Border between Romania (Giurgiu) and } \\
\text { Bulgaria (Ruse) }\end{array}$ \\
\hline \multicolumn{4}{|c|}{ Crossing countries - Bulgaria } \\
\hline Ruse-Dimitrovgrad & 260 & $\begin{array}{l}25 \mathrm{kV} \mathrm{AC} \\
50 \mathrm{~Hz}\end{array}$ & $\begin{array}{c}\text { Changing types of traction on Ruse } \\
\text { station }\end{array}$ \\
\hline $\begin{array}{l}\text { Dimitrovgrad- } \\
\text { Svilengrad }\end{array}$ & 80 & $\begin{array}{l}\text { Non- } \\
\text { electrified }\end{array}$ & $\begin{array}{c}\text { Changing types of traction on } \\
\text { Dimitrovgrad station (diesel); border } \\
\text { between Bulgaria (Svilengrad) and Turkey } \\
\text { (Kapikule) }\end{array}$ \\
\hline \multicolumn{4}{|c|}{ Crossing countries - Turkey } \\
\hline Kapikule-Istanbul & 250 & $\begin{array}{c}25 \mathrm{kV} \mathrm{AC} \\
50 \mathrm{~Hz}\end{array}$ & $\begin{array}{c}\text { Changing types of traction on Kapikule } \\
\text { station }\end{array}$ \\
\hline $\begin{array}{l}\text { Istanbul-Ankara } \\
\text { (Kayash) }\end{array}$ & 550 & $\begin{array}{l}25 \mathrm{kV} \mathrm{AC} \\
50 \mathrm{~Hz}\end{array}$ & $\begin{array}{l}\text { Changing types of traction on Kayash } \\
\text { station (diesel) }\end{array}$ \\
\hline $\begin{array}{l}\text { Ankara (Kayash) - } \\
\text { Kars (Dogukapy) }\end{array}$ & 1200 & $\begin{array}{l}\text { Non- } \\
\text { electrified }\end{array}$ & $\begin{array}{c}\text { Border between Turkey (Dogukapy) and } \\
\text { Armenia (Akhuryan) }\end{array}$ \\
\hline \multicolumn{4}{|c|}{ Crossing countries - Armenia (or Georgia) } \\
\hline Akhuryan-Ayrum & 160 & $3 \mathrm{kV} \mathrm{DC}$ & $\begin{array}{c}\text { Track gauge changing on Akhuryan } \\
\text { station (1435/1520 mm); border } \\
\text { between Armenia (Ayrum) and Georgia } \\
\text { (Sadachalo) }\end{array}$ \\
\hline \multicolumn{4}{|c|}{ Crossing countries - Georgia (or Armenia) } \\
\hline Sadachalo-Gardabani & 110 & $3 \mathrm{kV} \mathrm{DC}$ & $\begin{array}{c}\text { Border between Georgia (Gardabani) and } \\
\text { Azerbaijan (Boyuk Kasik) }\end{array}$ \\
\hline
\end{tabular}


C. Connection: Western Europe-China via the TRACECA corridor (Silk Road)

C1. Via the TRACECA-Turkmenbashi rail route

C1.2

Crossing countries - Azerbaijan

\begin{tabular}{|c|c|c|c|}
\hline Boyuk Kasik-Baku & 500 & $3 \mathrm{kV} \mathrm{DC}$ & - \\
\hline \multicolumn{4}{|c|}{ Caspian Sea } \\
\hline Baku-Turkmenbashi & 270 & water route & - \\
\hline \multicolumn{4}{|c|}{ Crossing countries - Turkmenistan } \\
\hline $\begin{array}{l}\text { Turkmenbashy-Farap } \\
\text { (via Turkmenabad) }\end{array}$ & 1120 & $\begin{array}{l}\text { Non- } \\
\text { electrified }\end{array}$ & $\begin{array}{l}\text { Border between Turkmenistan (Farap) } \\
\text { and Uzbekistan (Khodza Davlet) }\end{array}$ \\
\hline \multicolumn{4}{|c|}{ Crossing countries - Uzbekistan } \\
\hline $\begin{array}{l}\text { Khodza Davlet- } \\
\text { Marokand }\end{array}$ & 330 & $\begin{array}{l}\text { Non- } \\
\text { electrified }\end{array}$ & $\begin{array}{c}\text { Changing types of traction on Marokand } \\
\text { station }\end{array}$ \\
\hline Marokand-Keles & 400 & $\begin{array}{l}25 \mathrm{kV} \mathrm{AC} \\
50 \mathrm{~Hz}\end{array}$ & $\begin{array}{c}\text { Border between Uzbekistan (Keles) and } \\
\text { Kazakhstan (Sary Agash) }\end{array}$ \\
\hline \multicolumn{4}{|c|}{ Crossing countries - Kazakhstan } \\
\hline Sary Agash-Almaty & 950 & $\begin{array}{l}25 \mathrm{kV} \mathrm{AC} \\
50 \mathrm{~Hz}\end{array}$ & $\begin{array}{l}\text { Changing types of traction on Almaty } \\
\text { station (diesel) }\end{array}$ \\
\hline Almaty-Dostyk & 870 & $\begin{array}{l}\text { Non- } \\
\text { electrified }\end{array}$ & $\begin{array}{l}\text { Border between Kazakhstan (Dostyk) and } \\
\text { China (Alashankou) }\end{array}$ \\
\hline \multicolumn{4}{|c|}{ Crossing countries - China } \\
\hline Alashankou-Wuwei & 2000 & $\begin{array}{l}\text { Non- } \\
\text { electrified }\end{array}$ & $\begin{array}{l}\text { Track gauge changing on Alashankou } \\
\text { station }(1520 / 1435 \mathrm{~mm})\end{array}$ \\
\hline Wuwei-Lanzhou & 300 & $\begin{array}{l}25 \mathrm{kV} \mathrm{AC} \\
50 \mathrm{~Hz}\end{array}$ & $\begin{array}{c}\text { Changing types of traction on Wuwei } \\
\text { station }\end{array}$ \\
\hline Lanzhou-Zhengzhou & 1200 & $\begin{array}{l}25 \mathrm{kV} \mathrm{AC} \\
50 \mathrm{~Hz}\end{array}$ & - \\
\hline Zhengzhou-Beijing & 700 & $\begin{array}{l}25 \mathrm{kV} \mathrm{AC} \\
50 \mathrm{~Hz}\end{array}$ & - \\
\hline Total length ra & ay corri & $\mathrm{C} 1.2$ & $12440 \mathrm{~km}$ \\
\hline \multicolumn{4}{|c|}{ Types of traction } \\
\hline \multicolumn{3}{|c|}{$3 \mathrm{kV} \mathrm{DC}$} & $770 \mathrm{~km}(6 \%)$ \\
\hline \multicolumn{3}{|c|}{$25 \mathrm{kV}$ AC $50 \mathrm{~Hz}$} & $5710 \mathrm{~km}(46 \%)$ \\
\hline \multicolumn{3}{|c|}{ Non-electrified } & $5690 \mathrm{~km}(46 \%)$ \\
\hline \multicolumn{3}{|c|}{ Water route } & $270 \mathrm{~km}(2 \%)$ \\
\hline
\end{tabular}


C. Connection: Western Europe-China via the TRACECA corridor (Silk Road)

C2. Land detour of the Black Sea through Ukraine and Russia

\section{C2.1 Via the TRACECA-Aktau route}

\section{Crossing countries - Slovakia}

\begin{tabular}{|c|c|c|c|}
\hline Routes & $\begin{array}{l}\text { Length } \\
(\mathrm{km})\end{array}$ & $\begin{array}{l}\text { Types of } \\
\text { traction }\end{array}$ & Remarks \\
\hline Bratislava-Košice & 450 & $\begin{array}{l}25 \mathrm{kV} \mathrm{AC} \\
50 \mathrm{~Hz}\end{array}$ & Track gauge $1435 \mathrm{~mm}$ \\
\hline $\begin{array}{l}\text { Košice-Cierna nad } \\
\text { tisou }\end{array}$ & 95 & $\begin{array}{l}25 \mathrm{kV} \mathrm{AC} \\
50 \mathrm{~Hz}\end{array}$ & $\begin{array}{l}\text { Border between Slovakia (Cierna nad } \\
\text { tisou) and Ukraine (Chop) }\end{array}$ \\
\hline \multicolumn{4}{|c|}{ Crossing countries - Ukraine } \\
\hline Chop-Lviv & 270 & $3 \mathrm{kV} \mathrm{DC}$ & $\begin{array}{l}\text { Track gauge changing on Chop station } \\
(1435 / 1520 \mathrm{~mm}) \text { and changing types of } \\
\text { traction. }\end{array}$ \\
\hline Lviv-Fastov & 510 & $\begin{array}{l}25 \mathrm{kV} \mathrm{AC} \\
50 \mathrm{~Hz}\end{array}$ & $\begin{array}{c}\text { Changing types of traction on Lviv } \\
\text { station }\end{array}$ \\
\hline Fastov-Piatihatki & 410 & $25 \mathrm{kV} \mathrm{AC} 50 \mathrm{~Hz}$ & - \\
\hline $\begin{array}{c}\text { Piatihatki- } \\
\text { Dnepropetrovsk }\end{array}$ & 120 & $3 \mathrm{kV} \mathrm{DC}$ & $\begin{array}{c}\text { Changing types of traction on } \\
\text { Piatihatki station }\end{array}$ \\
\hline $\begin{array}{l}\text { Dnepropetrovsk- } \\
\text { Ilovaysk }\end{array}$ & 310 & $3 \mathrm{kV} \mathrm{DC}$ & $\begin{array}{c}\text { Changing types of traction on Ilovaysk } \\
\text { station }\end{array}$ \\
\hline Ilovaysk-Kvashino & 50 & $\begin{array}{l}25 \mathrm{kV} \mathrm{AC} \\
50 \mathrm{~Hz}\end{array}$ & $\begin{array}{l}\text { Border between Ukraine (Kvashino) } \\
\text { and Russia (Uspenskay) }\end{array}$ \\
\hline \multicolumn{4}{|c|}{ Crossing countries - Russia } \\
\hline Uspenskay-Rostov & 130 & $\begin{array}{l}25 \mathrm{kV} \mathrm{AC} \\
50 \mathrm{~Hz}\end{array}$ & - \\
\hline $\begin{array}{l}\text { Rostov-Stavropol- } \\
\text { Samur }\end{array}$ & 1070 & $\begin{array}{l}25 \mathrm{kV} \mathrm{AC} \\
50 \mathrm{~Hz}\end{array}$ & $\begin{array}{l}\text { Border between Russia (Samur) and } \\
\text { Azerbaijan (Yalama); changing types of } \\
\text { traction on Yalama station }\end{array}$ \\
\hline \multicolumn{4}{|c|}{ Crossing countries - Azerbaijan } \\
\hline Samur-Yalama-Baku & 210 & $3 \mathrm{kV} \mathrm{DC}$ & - \\
\hline \multicolumn{4}{|c|}{ Caspian Sea } \\
\hline Baku-Aktau & 370 & water route & - \\
\hline \multicolumn{4}{|c|}{ Crossing countries - Kazakhstan } \\
\hline Aktau-Makat & 710 & Non-electrified & - \\
\hline Makat-Kandagash & 400 & Non-electrified & - \\
\hline $\begin{array}{l}\text { Kandagash-Sary } \\
\text { Agash }\end{array}$ & 1460 & Non-electrified & $\begin{array}{c}\text { Changing types of traction on Sary } \\
\text { Agash (Arys) station }\end{array}$ \\
\hline Sary Agash-Almaty & 950 & $\begin{array}{l}25 \mathrm{kV} \mathrm{AC} \\
50 \mathrm{~Hz}\end{array}$ & $\begin{array}{l}\text { Changing types of traction on Almaty } \\
\text { station (diesel) }\end{array}$ \\
\hline Almaty-Dostyk & 870 & Non-electrified & $\begin{array}{l}\text { Border between Kazakhstan (Dostyk) } \\
\text { and China (Alashankou) }\end{array}$ \\
\hline
\end{tabular}




\section{Connection: Western Europe-China via the TRACECA corridor (Silk Road)}

C2. Land detour of the Black Sea through Ukraine and Russia

\section{C2.1 Via the TRACECA-Aktau route}

C. Connection: Western Europe-China via the TRACECA corridor (Silk Road)

C2. Via the TRACECA-Aktau Route

$\mathrm{C} 2.2$

\begin{tabular}{|c|c|c|c|}
\hline \multicolumn{4}{|c|}{ Crossing countries - Slovakia } \\
\hline Routes & $\begin{array}{c}\text { Length } \\
(\mathrm{km})\end{array}$ & Types of traction & Remarks \\
\hline Bratislava-Štúrovo & 150 & $\begin{array}{l}25 \mathrm{kV} \mathrm{AC} \\
50 \mathrm{~Hz}\end{array}$ & $\begin{array}{c}\text { Track gauge } 1435 \mathrm{~mm} ; \\
\text { Border between Slovakia (Štúrovo) and } \\
\text { Hungary (Szob) }\end{array}$ \\
\hline \multicolumn{4}{|c|}{ Crossing countries - Hungary } \\
\hline Szob-Budapest & 50 & $\begin{array}{c}25 \mathrm{kV} \mathrm{AC} \\
50 \mathrm{~Hz}\end{array}$ & - \\
\hline Budapest-Lőkösháza & 250 & $\begin{array}{l}25 \mathrm{kV} \mathrm{AC} \\
50 \mathrm{~Hz}\end{array}$ & $\begin{array}{l}\text { Border between Hungary (Lőkösháza) } \\
\text { and Romania (Curtici) }\end{array}$ \\
\hline \multicolumn{4}{|c|}{ Crossing countries - Romania } \\
\hline Curtici-Bucharest & 650 & $\begin{array}{l}25 \mathrm{kV} \mathrm{AC} \\
50 \mathrm{~Hz}\end{array}$ & $\begin{array}{l}\text { Changing types of traction on } \\
\text { Bucharest station (diesel) }\end{array}$ \\
\hline Bucharest-Giurgiu & 90 & Non-electrified & $\begin{array}{c}\text { Border between Romania (Giurgiu) and } \\
\text { Bulgaria (Ruse) }\end{array}$ \\
\hline \multicolumn{4}{|c|}{ Crossing countries - Bulgaria } \\
\hline Ruse-Dimitrovgrad & 260 & $\begin{array}{l}25 \mathrm{kV} \mathrm{AC} \\
50 \mathrm{~Hz}\end{array}$ & $\begin{array}{l}\text { Changing types of traction on } \\
\text { Ruse station }\end{array}$ \\
\hline $\begin{array}{l}\text { Dimitrovgrad- } \\
\text { Svilengrad }\end{array}$ & 80 & Non-electrified & $\begin{array}{c}\text { Changing types of traction on } \\
\text { Dimitrovgrad station (diesel); border } \\
\text { between Bulgaria (Svilengrad) and } \\
\text { Turkey (Kapikule) }\end{array}$ \\
\hline
\end{tabular}


C. Connection: Western Europe-China via the TRACECA corridor (Silk Road)

C2. Via the TRACECA-Aktau Route

C2.2

\begin{tabular}{|c|c|c|c|}
\hline \multicolumn{4}{|c|}{ Crossing countries - Turkey } \\
\hline Kapikule-Istanbul & 250 & $\begin{array}{l}25 \mathrm{kV} \mathrm{AC} \\
50 \mathrm{~Hz}\end{array}$ & $\begin{array}{c}\text { Changing types of traction on Kapikule } \\
\text { station }\end{array}$ \\
\hline $\begin{array}{l}\text { Istanbul-Ankara } \\
\text { (Kayash) }\end{array}$ & 550 & $\begin{array}{l}25 \mathrm{kV} \mathrm{AC} \\
50 \mathrm{~Hz}\end{array}$ & $\begin{array}{l}\text { Changing types of traction on Kayash } \\
\text { station (diesel) }\end{array}$ \\
\hline $\begin{array}{l}\text { Ankara (Kayash) - } \\
\text { Kars (Dogukapy) }\end{array}$ & 1200 & Non-electrified & $\begin{array}{l}\text { Border between Turkey (Dogukapy) } \\
\text { and Armenia (Akhuryan) }\end{array}$ \\
\hline \multicolumn{4}{|c|}{ Crossing countries - Armenia (or Georgia) } \\
\hline Akhuryan-Ayrum & 160 & $3 \mathrm{kV} \mathrm{DC}$ & $\begin{array}{c}\text { Track gauge changing on Akhuryan } \\
\text { station (1435/1520); border between } \\
\text { Armenia (Ayrum) and Georgia } \\
\text { (Sadachalo) }\end{array}$ \\
\hline \multicolumn{4}{|c|}{ Crossing countries - Georgia (or Armenia) } \\
\hline Sadachalo-Gardabani & 110 & $3 \mathrm{kV} \mathrm{DC}$ & $\begin{array}{l}\text { Border between Georgia (Gardabani) } \\
\text { and Azerbaijan (Boyuk Kasik) }\end{array}$ \\
\hline \multicolumn{4}{|c|}{ Crossing countries - Azerbaijan } \\
\hline Samur-Yalama-Baku & 210 & $3 \mathrm{kV} \mathrm{DC}$ & - \\
\hline \multicolumn{4}{|c|}{ Caspian Sea } \\
\hline Baku-Turkmenbashy & 270 & water route & - \\
\hline \multicolumn{4}{|c|}{ Crossing countries - Kazakhstan } \\
\hline Aktau-Makat & 710 & Non-electrified & - \\
\hline Makat-Kandagash & 400 & Non-electrified & - \\
\hline $\begin{array}{l}\text { Kandagash-Sary } \\
\text { Agash }\end{array}$ & 1460 & Non-electrified & $\begin{array}{c}\text { Changing types of traction on - Sary } \\
\text { Agash (Arys) station }\end{array}$ \\
\hline Sary Agash-Almaty & 950 & $\begin{array}{l}25 \mathrm{kV} \mathrm{AC} \\
50 \mathrm{~Hz}\end{array}$ & $\begin{array}{l}\text { Changing types of traction on Almaty } \\
\text { station (diesel) }\end{array}$ \\
\hline Almaty-Dostyk & 870 & Non-electrified & $\begin{array}{l}\text { Border between Kazakhstan (Dostyk) } \\
\text { and China (Alashankou) }\end{array}$ \\
\hline \multicolumn{4}{|c|}{ Crossing countries - China } \\
\hline Alashankou-Wuwei & 2000 & Non-electrified & $\begin{array}{l}\text { Changing types of traction on Wuwei } \\
\text { station; track gauge changing on } \\
\text { Alashankou station }(1520 / 1435 \mathrm{~mm})\end{array}$ \\
\hline Wuwei-Lanzhou & 300 & $\begin{array}{c}25 \mathrm{kV} \mathrm{AC} \\
50 \mathrm{~Hz}\end{array}$ & - \\
\hline Lanzhou-Zhengzhou & 1200 & $\begin{array}{l}25 \mathrm{kV} \mathrm{AC} \\
50 \mathrm{~Hz}\end{array}$ & - \\
\hline Zhengzhou-Beijing & 700 & $\begin{array}{l}25 \mathrm{kV} \mathrm{AC} \\
50 \mathrm{~Hz}\end{array}$ & - \\
\hline
\end{tabular}

Total length railway corridors $\mathbf{C} 2.2$

$12710 \mathrm{~km}$

Types of traction

$3 \mathrm{kV} \mathrm{DC}$

$320 \mathrm{~km} \mathrm{(3 \% )}$

$25 \mathrm{kV}$ AC $50 \mathrm{~Hz}$

$5310 \mathrm{~km}(42 \%)$

Non-electrified

$6810 \mathrm{~km}(54 \%)$

Water route

270 km (2\%) 
D: Connection: Western Europe-China via the Central Corridor in Kazakhstan

Crossing countries - Poland

\begin{tabular}{|c|c|c|c|}
\hline Routes & $\begin{array}{c}\text { Length } \\
(\mathrm{km})\end{array}$ & $\begin{array}{l}\text { Types of } \\
\text { traction }\end{array}$ & Remarks \\
\hline Warsaw-Krakow & 300 & $3 \mathrm{kV} \mathrm{DC}$ & - \\
\hline Krakow-Mostys'ka & 200 & $3 \mathrm{kV} \mathrm{DC}$ & $\begin{array}{c}\text { Track gauge changing on Mostys'ka } \\
\text { station (1435/1520); border between } \\
\text { Poland and Ukraine }\end{array}$ \\
\hline \multicolumn{4}{|c|}{ Crossing countries - Ukraine } \\
\hline Mostys'ka-Lviv & 70 & $3 \mathrm{kV} \mathrm{DC}$ & $\begin{array}{c}\text { Changing types of traction on Lviv } \\
\text { station }\end{array}$ \\
\hline Lviv-Kyiv & 580 & $\begin{array}{l}25 \mathrm{kV} \mathrm{AC} \\
50 \mathrm{~Hz}\end{array}$ & - \\
\hline $\begin{array}{l}\text { Kyiv-Hutor- } \\
\text { Mikhailowsky }\end{array}$ & 340 & $\begin{array}{l}25 \mathrm{kV} \mathrm{AC} \\
50 \mathrm{~Hz}\end{array}$ & $\begin{array}{l}\text { Border between Ukraine and Belarus } \\
\text { on Hutor-Mikhailowsky station }\end{array}$ \\
\hline \multicolumn{4}{|c|}{ Crossing countries - Belarus } \\
\hline $\begin{array}{l}\text { Hutor-Mikhailowsky- } \\
\text { Suhinichi }\end{array}$ & 250 & $\begin{array}{l}25 \mathrm{kV} \mathrm{AC} \\
50 \mathrm{~Hz}\end{array}$ & $\begin{array}{c}\text { Changing types of traction on } \\
\text { Suhinichi station. Border between } \\
\text { Belarus and Russia }\end{array}$ \\
\hline \multicolumn{4}{|c|}{ Crossing countries - Russia } \\
\hline Suhinichi-Moscow & 300 & $3 \mathrm{kV} \mathrm{DC}$ & - \\
\hline Moscow-Ryzan & 215 & $3 \mathrm{kV} \mathrm{DC}$ & $\begin{array}{c}\text { Changing types of traction on Ryzan } \\
\text { station }\end{array}$ \\
\hline Ryzan-Michurinsk & 250 & $\begin{array}{l}25 \mathrm{kV} \mathrm{AC} \\
50 \mathrm{~Hz}\end{array}$ & $\begin{array}{l}\text { Changing types of traction on } \\
\text { Michurinsk station }\end{array}$ \\
\hline Michurinsk-Rtischevo & 270 & Non-electrified & $\begin{array}{l}\text { Changing types of traction on } \\
\text { Michurinsk station (diesel) }\end{array}$ \\
\hline Rtischevo-Saratov & 200 & $\begin{array}{l}25 \mathrm{kV} \mathrm{AC} \\
50 \mathrm{~Hz}\end{array}$ & $\begin{array}{l}\text { Changing types of traction on } \\
\text { Rtischevo station }\end{array}$ \\
\hline Saratov-Aksarayskay & 630 & Non-electrified & $\begin{array}{c}\text { Changing types of traction on Saratov } \\
\text { station (diesel); border between Russia } \\
\text { and Kazakhstan on Aksarayskay } \\
\text { station }\end{array}$ \\
\hline \multicolumn{4}{|c|}{ Crossing countries - Kazakhstan } \\
\hline Aksarayskay-Makat & 460 & Non-electrified & - \\
\hline Makat-Kandagash & 400 & Non-electrified & - \\
\hline $\begin{array}{l}\text { Kandagash-Sary } \\
\text { Agash }\end{array}$ & 1460 & Non-electrified & $\begin{array}{c}\text { Changing types of traction on - Sary } \\
\text { Agash (Arys) station }\end{array}$ \\
\hline Sary Agash-Almaty & 950 & $\begin{array}{l}25 \mathrm{kV} \mathrm{AC} \\
50 \mathrm{~Hz}\end{array}$ & $\begin{array}{l}\text { Changing types of traction on Almaty } \\
\text { station (diesel) }\end{array}$ \\
\hline Almaty-Dostyk & 870 & Non-electrified & $\begin{array}{l}\text { Border between Kazakhstan (Dostyk) } \\
\text { and China (Alashankou) }\end{array}$ \\
\hline
\end{tabular}


D: Connection: Western Europe-China via the Central Corridor in Kazakhstan Crossing countries - Poland

\begin{tabular}{|c|c|c|c|}
\hline Routes & $\begin{array}{c}\text { Length } \\
(\mathrm{km})\end{array}$ & $\begin{array}{l}\text { Types of } \\
\text { traction }\end{array}$ & Remarks \\
\hline \multicolumn{4}{|c|}{ Crossing countries - China } \\
\hline Alashankou-Wuwei & 2000 & Non-electrified & $\begin{array}{l}\text { Changing types of traction on Wuwei } \\
\text { station; track gauge changing on } \\
\text { Alashankou station }(1520 / 1435 \mathrm{~mm})\end{array}$ \\
\hline Wuwei-Lanzhou & 300 & $\begin{array}{c}25 \mathrm{kV} \mathrm{AC} \\
50 \mathrm{~Hz}\end{array}$ & - \\
\hline Lanzhou-Zhengzhou & 1200 & $\begin{array}{c}25 \mathrm{kV} \mathrm{AC} \\
50 \mathrm{~Hz}\end{array}$ & - \\
\hline Zhengzhou-Beijing & 700 & $\begin{array}{c}25 \mathrm{kV} \mathrm{AC} \\
50 \mathrm{~Hz}\end{array}$ & - \\
\hline \multicolumn{3}{|c|}{ Total length railway corridors D } & $11645 \mathrm{~km}$ \\
\hline \multicolumn{4}{|c|}{ Types of traction } \\
\hline \multicolumn{3}{|c|}{$3 \mathrm{kV} \mathrm{DC}$} & 1085 km (9\%) \\
\hline \multicolumn{3}{|c|}{$25 \mathrm{kV} \mathrm{AC} 50 \mathrm{~Hz}$} & $4770 \mathrm{~km}(40 \%)$ \\
\hline \multicolumn{3}{|c|}{ Non-electrified } & 6090 km (51\%) \\
\hline
\end{tabular}

E: Connection: Western Europe-India via the Trans-Asian railway route Crossing countries - Slovakia

\begin{tabular}{cccc}
\hline Routes & $\begin{array}{c}\text { Length } \\
(\mathrm{km})\end{array}$ & $\begin{array}{c}\text { Types of } \\
\text { traction }\end{array}$ & Remarks \\
\hline Bratislava-Štúrovo & 150 & $\begin{array}{c}25 \mathrm{kV} \mathrm{AC} \\
50 \mathrm{~Hz}\end{array}$ & $\begin{array}{c}\text { Track gauge 1435 mm; } \\
\text { border between Slovakia (Štúrovo) and } \\
\text { Hungary (Szob) }\end{array}$ \\
\hline Szob-Budapest & 50 & $\begin{array}{c}25 \mathrm{kV} \mathrm{AC} \\
50 \mathrm{~Hz}\end{array}$ & - \\
\hline Budapest-Lőkösháza & 250 & $\begin{array}{c}25 \mathrm{kV} \mathrm{AC} \\
50 \mathrm{~Hz}\end{array}$ & $\begin{array}{c}\text { Border between Hungary (Lökösháza) } \\
\text { and Romania (Curtici) }\end{array}$ \\
\hline Curtici-Bucharest & 650 & $\begin{array}{c}25 \mathrm{kV} \mathrm{AC} \\
50 \mathrm{~Hz}\end{array}$ & $\begin{array}{c}\text { Changing types of traction on } \\
\text { Bucharest station (diesel) }\end{array}$ \\
\hline Bucharest-Giurgiu & 90 & Non-electrified & $\begin{array}{c}\text { Border between Romania (Giurgiu) and } \\
\text { Bulgaria (Ruse) }\end{array}$ \\
\hline
\end{tabular}


E: Connection: Western Europe-India via the Trans-Asian railway route

Crossing countries - Bulgaria

\begin{tabular}{|c|c|c|c|}
\hline Ruse-Dimitrovgrad & 260 & $\begin{array}{l}25 \mathrm{kV} \mathrm{AC} \\
50 \mathrm{~Hz}\end{array}$ & $\begin{array}{c}\text { Changing types of traction on Ruse } \\
\text { station }\end{array}$ \\
\hline $\begin{array}{l}\text { Dimitrovgrad- } \\
\text { Svilengrad }\end{array}$ & 80 & Non-electrified & $\begin{array}{c}\text { Changing types of traction on } \\
\text { Dimitrovgrad station (diesel); border } \\
\text { between Bulgaria (Svilengrad) and } \\
\text { Turkey (Kapikule) }\end{array}$ \\
\hline \multicolumn{4}{|c|}{ Crossing countries - Turkey } \\
\hline Kapikule-Istanbul & 250 & $\begin{array}{l}25 \mathrm{kV} \mathrm{AC} \\
50 \mathrm{~Hz}\end{array}$ & $\begin{array}{c}\text { Changing types of traction on Kapikule } \\
\text { station }\end{array}$ \\
\hline $\begin{array}{l}\text { Istanbul-Ankara } \\
\text { (Kayash) }\end{array}$ & 550 & $\begin{array}{l}25 \mathrm{kV} \mathrm{AC} \\
50 \mathrm{~Hz}\end{array}$ & $\begin{array}{c}\text { Changing types of traction on Kayash } \\
\text { station (diesel) }\end{array}$ \\
\hline $\begin{array}{l}\text { Ankara (Kayash) - } \\
\text { Tatvan }\end{array}$ & 1300 & Non-electrified & - \\
\hline Tatvan-Van & 140 & water route & - \\
\hline Van-Kapıköy & 130 & Non-electrified & $\begin{array}{l}\text { Border between Turkey (Kapıköy) and } \\
\text { Iran (Razi) }\end{array}$ \\
\hline \multicolumn{4}{|c|}{ Crossing countries - Iran } \\
\hline Razi-Tehran & 850 & Non-electrified & - \\
\hline Tehran-Zahedan & 1120 & Non-electrified & $\begin{array}{c}\text { Border between Iran (Zahedan) } \\
\text { and Pakistan (Kuhi Taftan); track } \\
\text { gauge changing on Zahedan station } \\
(1435 / 1676 \mathrm{~mm})\end{array}$ \\
\hline \multicolumn{4}{|c|}{ Crossing countries - Pakistan } \\
\hline KuhI Taftan-Lahore & 1600 & Non-electrified & $\begin{array}{c}\text { Border between Iran (Amritsar) and } \\
\text { Pakistan (Lahore) }\end{array}$ \\
\hline \multicolumn{4}{|c|}{ Crossing countries - India } \\
\hline Amritsar-Beas & 40 & Non-electrified & $\begin{array}{c}\text { Changing types of traction on Beas } \\
\text { station }\end{array}$ \\
\hline Beas-New Delhi & 460 & $\begin{array}{l}25 \mathrm{kV} \mathrm{AC} \\
50 \mathrm{~Hz}\end{array}$ & - \\
\hline Total lengt & lway cc & ors E & $7970 \mathrm{~km}$ \\
\hline \multicolumn{4}{|c|}{ Types of traction } \\
\hline \multicolumn{3}{|c|}{$25 \mathrm{kV} \mathrm{AC} 50 \mathrm{~Hz}$} & 2620 km (33\%) \\
\hline \multicolumn{3}{|c|}{ Non-electrified } & $5210 \mathrm{~km}(65 \%)$ \\
\hline \multicolumn{3}{|c|}{ Water route } & 140 km (2\%) \\
\hline
\end{tabular}




\subsection{Analysis of the current situation of the railway infrastructure}

\subsubsection{Maximum axle load}

The permitted axle load on the examined Europe-Asia railway corridors, clustered per crossing country, is presented in Table 6 .

Table 6 indicates the incompatibility in the same corridor in terms of permitted axle load. The values vary both between countries and between segments in the same country. This leads, inevitably, to the composition of block trains of axle load equal to or less than the minimum permitted axle load along the whole connection.

The limitation on the permitted axle load in different countries or in different railway segments in the same country could be attributed to:

1. Narrower track gauges (railway lines of larger gauge enable bigger axle loads); lower mechanical duration of the railway superstructure (track panel and track bed)

2. Inefficiency of the static and dynamic behaviour of the body of the civil engineering structures

3. Presence of high longitudinal slopes and high length of inclines

4. Absence of electrification

5. Combination of the aforementioned factors

While trying to increase the axle load, the factors that could create severe technical problems are the existence of narrower track gauge and steep vertical alignment design.

Nonetheless, all the above issues could be dealt with, taking into consideration the following:

In practice, a possible increase of the axle load is not dealt with by the broadening of the track gauge, but rather, by the increase of the mechanical duration of the elements of the superstructure (i.e. rails of higher moment of inertia, therefore of bigger weight).

The issue of the high longitudinal gradients can be resolved with the installation of electrification and/or the use of power vehicles of higher traction power, or different variants in the track layout design.

\subsubsection{Maximum train length}

The maximum length of the trains that are permitted to move along the railway networks of the countries under examination varies from country to country or from railway section to railway section within the same country (Table 6 and Table 7). This leads, inevitably, to the composition of block trains of lengths equal to or less than the maximum permitted train length along the whole connection. 
The limitations on the maximum train length can be attributed to the following:

1. The need to reduce, for specific axle loads, the total weight of the trains; this need, in turn, can be caused by the presence of high longitudinal gradients and high length of inclines, as well as by the absence of electrification

2. The presence of smaller platform lengths and track layout in the stations

3. The non-use of automatic vehicle coupling systems

4. The signaling system

5. A combination of the above factors

While trying to increase the train length for the same permitted axle load, the factors that could create severe technical problems are the presence of a steep vertical alignment design, and the insufficiency of the platform length and stations' alignment. Nonetheless, all these problems can be addressed.

\subsubsection{Track gauge}

Track gauge variations are presented along the Eurasian railway examined routes, more specifically, as can be seen from Table 6 and Table 7:

I. Along the Trans-Siberian railway network: Two different track gauges $(1435,1520$ $\mathrm{mm}$; one change of track gauge)

II. Along the Trans-Siberian railway network and the Manchurian Route: Two different track gauges (1435, $1520 \mathrm{~mm}$; two changes of track gauge)

III. Along the Trans-Siberian railway network and the Trans-Kazakh Route: Two different track gauges $(1435,1520 \mathrm{~mm}$; two changes of track gauge)

IV. Along the TRACECA-Turkmenbashi rail route: Two different track gauges (1435, $1520 \mathrm{~mm}$; two changes of track gauge)

V. Along the TRACECA-Aktau rail route: Two different track gauges (1435, $1520 \mathrm{~mm}$; two changes of track gauge)

VI. Along the connection Western Europe-China via the Central Corridor in Kazakhstan: Two different track gauges $(1435,1520 \mathrm{~mm}$; two changes of track gauge)

VII. Along the connection Europe-India via the Trans-Asian railway route: Two different track gauges $(1435,1676 \mathrm{~mm}$; one change of track gauge)

The difference of the track gauge between the countries and between the railway segments in the same country is the basic obstacle in the achievement of interoperability along the Eurasian railway corridors. The available solutions are the following:

6) Unification of the rail track gauge along the whole connection

7) Installation and operation of advanced systems for track gauge change 


\subsubsection{Maximum speed of freight and passenger trains}

The Europe-Asia railway connection is currently realized under track sections designed with various design speeds, while, on many occasions, the permissible track speeds vary significantly from the track design speeds.

Table 6 presents the maximum permissible speed for passenger and freight trains, clustered per crossing countries. As can be seen from the Table 6, the various track segments of the Europe-Asia rail corridors present different maximum permissible speeds. As a result, the running speed of the freight trains also varies. The reduction of the average running speed results in the increase of the average travel time.

Problems can be encountered due to a possible increase of the freight train speed when and if the design speed is lower than the desirable running speed. In such cases, interventions in the track layout design are demanded. On the contrary, in cases where the design speed is higher than the permitted speed, an increase of speeds can be achieved through the optimization of the track maintenance, or through soft interventions in the superstructure and the track installations.

It is worth mentioning a general problem caused by the traffic composition. The need to have passenger and freight trains sharing the same track has a significant impact on the design, construction, and maintenance of a railway system. By way of indication, in the case of constructing a single or double track for mixed train operation:

1. the alignment is determined by the design speed defined for passenger trains;

2. superstructure is built based on passenger train speed and freight train axle load;

3. track maintenance policy considers the daily traffic load made up of all trains; and

4. the train rooting schedule must include trains running at different speeds, whatever be the consequence to the track capacity.

Mixed networks primarily satisfy passenger transportation. This priority usually leads to resource inadequacy for freight trains, which are further delayed in favor of passenger trains. The cargo transportation market needs to differ from that of passenger transportation. This seems to enforce the progressive segregation of networks for passenger and freight transportation.

\subsubsection{Track capacity}

As can be seen in Table 7, along the Europe-Asia railway connection, there are railway sections of saturated track capacity, where the routing of additional trains is not feasible. In such cases, an increase in track capacity is demanded.

Track capacity depends on numerous parameters including: geometrical characteristics of the alignment and the longitudinal profile of the layout; traction and cinematic characteristics of the trains in operation; type and configuration of passing 
trains; signaling system installed; length of block sections; railway traffic rules; train schedules; frequency by train type; ability to absorb traffic at terminals; reception ability of intermediate stations, etc. These parameters make a precise calculation of the capacity of a track section somewhat complicated.

In this respect, various mathematical models have been developed and proposed. As a result, each IM, according to the network's characteristics and needs, adopts a different method to calculate track capacity.

The knowledge of track capacity is of major importance for the IM for the following reasons.

1. Capacity knowledge is required to handle direct problems during the operation of a network, such as the routing of new regular, occasional, or periodic trains on a track section, the scheduling organization, the safe train traffic, and the choice of the appropriate track equipment for this purpose, the reduction of delays, etc.

2. Capacity calculation is needed during the first phase of a feasibility study for the construction of a new track (single or double), the doubling of a track, the abolishment of existing tracks, and the installation of an electric signaling system.

3. Capacity monitoring supports the adoption of long-term measures related to the investment policy of infrastructure works, and, in general, the transport development policy in a specific geographic region.

4. Finally, track capacity calculation is the first step when the infrastructure manager has to take "path" allocation decisions (and afterwards capacity allocation) when dealing with the various RUs applying for passenger or cargo access to the specific railway infrastructure.

\subsubsection{Rolling stock static and dynamic gauge (clearance)}

The rolling stock static and dynamic gauge varies between the different segments of the Europe-Asia railway connection.

The civil engineering structures' gauge should allow the safe and non-reduced transit speed of the freight trains. Therefore, a minimum gauge should be defined along the corridors and, in cases of incompatibility, necessary interventions should be made in the open tracks, the civil engineering structures, and the track installations.

\subsubsection{Traction system}

As can be seen from Tables 6 and Table 7, along the railway connection of Europe to Asia, a significant portion is not electrified, while the electrified sections present different power supply systems. 
In cases of routing of diesel freight trains along the whole connection, no interoperability issues appear. On the contrary, in cases of electrification, where strong interoperability issues exist, there are three choices:

1. To provide the possibility of traction unit change along the railway corridor and, generally to optimize the traction management plan

2. To electrify each railway connection throughout its whole length

3. To provide multiple current electric traction units

\subsubsection{Signaling system}

The rail infrastructure of each country along Trans-Asian landmass includes different railway signaling systems.

\subsubsection{Maintenance}

It is necessary to specify how to manage the life cycle of all interlocking systems and equipment that will be used for the EU-Asia connection (design, requirements specification, development, production, operation, and disposal). Nowadays, the issue of RAMS and issues of safety assessment are seen in European countries. Application of certified, methodical procedures and methods for application of requirements according to EN 50126, EN 50128, EN 50129 in the railway system seems to be the right way to address these issues.

\subsection{Chapter conclusions}

At this level of analysis, the following research needs are identified:

1. Evaluation of the current track gauge change techniques and investigation of new, more efficient solutions; harmonization of the technical solutions

2. Analysis and evaluation of the existing railway corridors connecting Europe and Asia (track, rolling stock, exploitation)

3. Formulation of an action plan for ensuring the interoperability along the railway link Europe-Asia

4. Investigation and definition of the optimal permitted axle load, train composition length and fixed obstacle's gauge along the whole railway connection

5. A need for a common and agreed method for the calculation of track capacity; investigation and calculation of the track capacity along the alternatives railway corridors connecting Europe to Asia; formulation of an intervention plan for the increase of track capacity along the above corridors

6. Feasibility studies on the various alternative solutions for the traction systems

7. Feasibility studies on the various alternative solutions for the signaling systems

8. Feasibility studies for the operation of dedicated freight corridors in track sections of the corridors 


\section{RAIL SAFETY AND SECURITY SYSTEMS OF EUROPEAN AND ASIAN COUNTRIES}

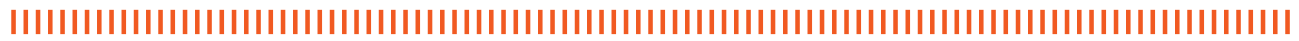

\subsection{Comparison analysis of rail safety and security systems}

\section{A. Rail safety and security systems}

Improving safety and security is imperative for all railway stakeholders. Railway safety is an interdisciplinary research area. As the rail industry becomes smarter, security becomes increasingly more important. In today's environment, rail industry is faced with a critical need to protect its passengers, employees, goods, infrastructures, and assets from possible threats with a smarter security system that enables rapid response to security breaches and prompts quicker investigation. Safety will be considered as an inherent component of the rail transport system relating to infrastructure, freight (goods and containers), transport users and operators, and rolling stock, as well as measures at policy and legislative levels, including decision support and validation tools. Essentially, security will be addressed wherever it is an inherent requirement in the transport system.

Europe: Safety and security are of primary concern for any transport system. The European rail industry is in a state of rapid transformation aimed at meeting the increasing safety, environmental, societal, and economic demands set for modern rail transport. Europe's railways are among the safest in the world. EU policies aim to maintain high standards and align safety requirements across the EU. The safety level of rail transport in the EU is generally very good, especially as compared to its main competitor, i.e., road transport. The European Railway Agency (ERA) plays a central role in promoting interoperability and harmonizing technical standards in EU (Gleave 2011). ERA develops common technical specifications and common approaches to safety, working closely with stakeholders from the rail sector as well as with national authorities, the EU institutions and other interested parties (Railway Safety Performance .... 2008). 
Development and management of rail safety in EU: Safety rules and standards, such as operating rules, signaling rules, requirements on staff, and technical requirements applicable to rolling stock have been mainly devised nationally. These national safety rules should gradually be replaced by rules based on common standards, established by technical specifications for interoperability (TSIs). In this connection, the EU member states will ensure that:

1) railway safety is generally maintained and continuously improved, taking into consideration the development of European legislation;

2) safety rules are laid down, applied and enforced in an open and non-discriminatory manner;

3) responsibility for the safe operation of the railway system and the control of risks associated with it is borne by the infrastructure managers and railway undertakings;

4) information is collected on common safety indicators through annual reports in order to assess the achievement of the CSTs and monitor the general development of railway safety.

The activities performed by the ERA aim at:

1) developing, promoting, and monitoring a common EU approach to safety management and governance across the agency stakeholders;

2) improving the interoperability of the European rail system by developing the conditions for the free and uninterrupted movement of trains through technical and operational harmonization, including conditions for mutual acceptance of railway vehicles. To this end, ERA develops common TSIs and common safety methods and targets (CSMs and CSTs), working closely with stakeholders from the rail sector, national authorities, the EU institutions, and other interested parties.

The concept of a Safety Management System (SMS) is a key element in the legislative framework to improve the safety performance in an open railway market, as set out by Directive 2004/49/EC (Railway Safety Directive [RSD]). RSD foresees a number of concrete instruments for effective railway safety management. They include EU regulatory framework, safety certification, and safety assessment. Some major remarks relate to the setting up and independence of the NSAs and the National Investigation Bodies (NIBs), and the development of the safety management system.

\section{Asian Countries}

India: Safety and security of Indian Railways is of paramount importance to the system. Over the years, apart from the regular safety norms followed, the network has taken a number of steps through the innovative use of technology and by stepping up the training to its manpower to enhance safety standards. A number of distressed bridges, old tracks, signaling systems, and other safety enhancement devices have been replaced. 
There have been extensive field trials of the anti-collision device (ACD) indigenously developed by the Konkan Railway, which uses innovative technology that will help the railways reduce accidents due to collision between two trains. The security of railway passengers is at present a shared responsibility of the Railway Protection Force (RPF) and the Government Reserve Police (GRP). Efforts are on to amend the Railway Act to give more powers to the RPF in ensuring security of passengers on trains and within railway premises. Women police have been deployed for the security and assistance of women passengers.

E-security measures have been designed to preserve the confidentiality and integrity of the users' data on the Internet. E-Lock digital signature solutions provide the basic e-security foundation for businesses. The solutions are designed to suit the business requirements of the user, making them user-friendly. E-Lock facilitates a secure and safe business environment for its users, which allows them to conduct business operations freely. E-Lock takes a great pride in serving various esteemed customers, spanning several verticals, across the globe. Being a pioneer in the field of digital signature technology, E-Lock understands its customers and their requirements, and delivers the right solutions, helping them achieve desired goals. E-Lock empowers businesses to go paperless with its eSig and dSig technologies.

China: An effective safety management system will help the organization involved in railway transport to identify and manage risks effectively. It allows an organization to demonstrate its capacity in performing its safety responsibilities and in meeting regulatory requirements. In the case of a railway safety management framework, there has existed a localized practical system connected with specific implementing circumstances in China.

- Legislation basis: In China, safety standards are enacted in the form of legal provisions. The clauses listed in these standards represent behavioural constraints of practitioners, particularly those involved in railway operation and management.

- Safety management entities: With regard to responsibility for safety, four levels of tasks are assigned, namely supervision level, strategy level, execution level, and implementation level, and safety policies are put into practice. Tyco Security is a one-stop rail security solution which addresses security needs. Shanghai Maglev Train authorities have deployed real-time monitoring systems, including anti-riot mini dome cameras with anti-vibration, anti-smash and anti-sabotage capabilities. Rail security management solutions are adopting multi-layered defences including:

a) External Intrusion Protection: The first line of defence-preventing terrorist incursions outside railway stations. This includes stopping criminals carrying hazardous materials close to the station and any of its entrances, vents, and tunnels. 
b) Regional protection: This is a second layer of protection which involves the electronic surveillance of stairs, elevators, and other easily concealed areas. A flagged intrusion triggers an alarm to a control center for appropriate actions.

Japan: Co-relational research on rail transportation safety and security systems is becoming highly valued. Japan's railways, due to its on-time arrivals, accurate operations, and safety and security, have played a major role in the nation's social development. These achievements are mostly based on the development and combination of various new technologies, and on the improvement of employees' skills. The Shinkansen (new trunk line), also known as the "bullet train," is a network of high-speed railway lines in Japan operated by four Japan Railways group companies. Shinkansen uses advanced technologies compared with conventional rail, and it has achieved not only high speeds, but also high standards of safety and comfort. Its success has influenced other railways around the world and the importance and advantage of high-speed rail has consequently been revalued. Over the Shinkansen's 49-year history of carrying nearly seven billion passengers, there have been no passenger fatalities due to derailments or collisions, despite frequent earthquakes and typhoons.

Russia: NICE Systems has been chosen to provide security to Russian rail transportation services between Moscow's rail terminals and its three airports. The NICE system will be integrated with a number of third party systems, including access control, a fire alarm panel, a GPS train tracking system, mobile DVR, and a video wall. High-speed rail is emerging in Russia as an increasingly popular means of transport, although its development is moving at a slower pace than in Western Europe.

\section{B. Euro-Asian connection}

An EU FP7 project titled "Sustainable Maintenance and Analysis of Rail Transport Infrastructure" (SMARTRail) is to provide a framework for infrastructure operators to ensure the safe, reliable, and efficient operation of ageing European railway networks. The outputs from the project will result in enhanced safety, reliability, and capacity of these rail infrastructure networks, and will address European policy in the areas of transport safety and security, inter-modality, opening up a European network for freight transport and routes to rapidly developing Eastern European and Asian markets.

\section{Relevant research questions/issues}

I. TRACECA: The Transport Corridor Europe Caucasus Asia (TRACECA) is a program aimed at strengthening the economic relations, trade, and transport communications in the regions of the Black Sea basin, South Caucasus, and Central Asia, 
responding to common aspirations of its member states. The European Union technical assistance program, TRACECA, was first launched in May 1993 and the "Basic Multilateral Agreement on International Transport for Development of the EuropeCaucasus-Asia Corridor" was signed in 1998 by Azerbaijan, Armenia, Bulgaria, Georgia, Kazakhstan, Kyrgyzstan, Moldova, Romania, Tajikistan, Turkey, Ukraine, and Uzbekistan. The main identified problems within the TRACECA region are the fragmentation of transport systems within and between transport modes due to technical and legal barriers; poor technology and insufficient organization at nodes and interchange points; lack of an integrated customs information system (ICIS); and low levels of safety and security.

II. One of the weaknesses of the trans-Asian route is the difficulty with guaranteeing the reliability of transport services (in terms of punctuality, safety, security and cargo information provision), high tariffs for transit cargoes, and the lack of transit cargo traceability due to a poor cargo information system (this was also happening along the Trans-Siberian route).

III. Improving safety and security of the new Eurasian land bridge should ensure flexible and appropriate policies and legal factors that ensure timely delivery.

I. People working on or around the track: Railway operation and maintenance requires several groups of staff to work on or around the track; these include track, overhead line, and signal maintenance staff, and shunters or couplers. This type of railway work has long been recognized as a relatively high-risk occupation, and deaths of such workers still regularly occur in almost all countries.

II. Train protection: Train accidents have a wide variety of causes, including rail vehicle or track defects, defects in the signaling systems, and human errors by operating staff. Accidents due to errors by signaling staff in normal operation have now become rare, because modern signaling systems have automatic protection against such human errors. However, accidents due to errors by drivers, such as passing signals at danger (SPAD) are more common, because it has been more difficult to develop automatic protection against these. Such errors are never deliberate, and they are very infrequent for each individual driver, but for systems as a whole they are a persistent problem.

I. Driver alertness: Driver alertness is closely related to the continuing problem of errors by drivers. The pressure to use staff with greater efficiency is leading to fewer and longer work duty periods for drivers, and to the use of single-operator shifts.

II. Level Crossings: Almost all railway systems have large numbers of level crossings, especially those in flat terrain (for example, the average density of level crossing locations varies from $1 \mathrm{~km}$ to $7 \mathrm{~km}$ in European countries). Most countries have statutory or non-statutory rules for the application and operation of level crossings. Such rules mandate the type of crossing that is to be used for specified road and rail traffic levels. 


\subsection{Railway traffic risk analysis and assessment}

\subsubsection{Overall description}

Regardless of whether for passenger transport or for freight transport, safety is the most important and basic requirement in railway transport, rather than aspects such as travel time and pricing. For railway transport, this is a complex and systematic problem. As it involves problems in several areas, such as rolling stock, communication and signal systems, and infrastructures, the system is somewhat vulnerable and faces many potential risks. Hence risk analysis and assessment is extremely necessary for railway transport. Vulnerability analysis is done mainly to identify the vulnerable elements on the network, while risk analysis is done mainly to determine which incidents are most likely to happen, and the consequences when such incidents do happen. Risk analysis is a more comprehensive task which needs more fundamental data. It is also the basis on which decision makers can take measures about maintaining the safety of the system.

\subsubsection{Relevance to the EU-Asia connection}

Maintaining the safety of railway transport is very important for the EU-Asian connection. As the connection concerns two continents and several countries, it is really a complex system which might have many risks. Therefore, conducting a risk analysis and a vulnerability analysis is absolutely necessary.

\subsubsection{Relevant research issues related to risk analysis that require further study}

Some issues that require further study are as follows:

1) Subsystem division of railway transport system

2) Risk identification model and method

3) EU-Asia railway transport network modelling

4) Vulnerability analysis

5) Potential solutions to control the risks and decrease the vulnerability

\subsection{Compatibility of rail safety policies}

This chapter aims at presenting the safety policies and recommendations from Europe and Asian countries to support the safety in the railways, in order to identify compatibility and harmonization of safety legislation and rules. The chapter focusses on safety management aspects and risk assessment criteria based on code of practices, system reference and risk estimation approaches. 


\subsubsection{European Union railway safety policy}

The European Safety Directive 2004/49/EC that came into force in 2004 and was amended by Directive 2009/149/EC in 2009, is focused on rail safety whilst ensuring the opening up of the rail market in Europe. The safety directive aims at harmonizing the regulatory structures that enforce railway operation and safety in the whole of the European Union and within each member states.

The purpose of the safety directive is to ensure the development and improvement of safety in the community's railways by:

1) maintaining the global railway safety in each member state;

2) harmonizing the regulatory structure in the member states;

3) dividing responsibilities between the players;

4) developing common safety methods (CSM) and common safety targets (CST);

5) requiring the establishment, in every EU member state, of national safety authorities and national bodies for accident investigation;

6) defining common principles for the management, regulation and supervision of railway safety;

7) describing the players involved in the railway safety management, as well as a harmonized structure of the safety management and the responsibilities of each player within it (the following sections elaborates on each of these points).

\subsubsection{Players involved in the railways safety management}

The safety management of the European railways is distributed among a few players at the EU level and/ or at the national level. These players include the following:

Infrastructures managers are any persons or undertakings that are responsible in particular for establishing and maintaining railway infrastructure. The functions of the infrastructure manager in a network or part of a network may be allocated to different bodies or undertakings. The safety authorization of an infrastructure manager should comprise acceptance of the provisions to meet specific requirements necessary for the safe design, maintenance, and operation of the railway infrastructure including, where appropriate, the maintenance and operation of the traffic control and signaling systems.

Railways undertakings are railway undertakings as defined in Directive 2001/14/ EC, and any other public or private undertaking, whose responsibility it is to provide transport of goods and/or passengers by rail with a requirement that the undertaking must ensure traction; this also includes undertakings which provide traction only. Railway undertakings are the second kind of railway companies directly involved in the Safety Directive. As with infrastructure managers, a railway undertaking is responsible for its portion of the system and its safe operation, including the supply of material and 
contracting of services, vis-à-vis users, customers, and third parties. If an infrastructure manager must obtain safety authorization, a railway undertaking must obtain a safety certificate in order to have access to a railway network or a part of it.

Safety authorities are the national bodies in each member state entrusted with the task of railway safety according to the provisions of the safety directive or any bi-national body entrusted by EU member states with these tasks, in order to ensure a unified safety regime on specialized cross-border infrastructure. Only one safety authority exists in each EU member state. This authority may be the Ministry responsible for transport matters, and can work independently from any infrastructure manager, railway undertaking, and applicant and procurement entity. The safety authority has the role of upervising and regulating the safety management system implemented in each infrastructure manager and in each railway undertaking in the EU member state. The supervisory and regulatory tasks of the safety authority apply on both infrastructure managers and railways undertakings. These include :

1. authorizing the bringing into service of the structural subsystems constituting the transEuropean rail system (high-speed and conventional) and checking that they are operated and maintained in accordance with the relevant essential requirements;

2. upervising that the interoperability constituents are in compliance with the essential requirements;

3. issuing, renewing, amending and revoking relevant parts of safety certificates and safety authorizations-the safety authority will check that conditions and requirements laid down in certificates are met and that infrastructure managers and railway undertakings are operating under the requirements laid down in rules under community or national law;

4. monitoring, promoting, and, where appropriate, enforcing and developing the safety regulatory framework including the system of national safety rules; and

5. upervising that rolling stocks are duly registered and that safety related information in the national register is accurate and kept up-to-date.

Investigating bodies are independent bodies in charge of the investigations of accidents and incidents. As with safety authorities, only one investigating body should exist at any given point in time in one EU member state. An investigating body shall comprise at least one investigator who will perform the function of investigator-in-charge in the event of an accident or incident. An investigating body has the responsibility to investigate serious accidents. To undertake its activities, an investigating body is totally independent from any infrastructure manager, railway undertaking, charging body, allocation body, notified body, and any other party whose interests could conflict with the tasks entrusted to the investigating body. It is, furthermore, functionally independent 
of the safety authority and of any regulator of railways. The investigation has a legal status in each member state's legislation framework.

Member states are the members of the European community. It is the responsibility of each member state to take the lead role in ensuring that railway safety is generally maintained, and, where reasonably practicable, continuously improved upon, taking into consideration the development of the community legislation, technical, and scientific progress, giving priority to the prevention of serious accidents. The member state responsibilities include the following :

1. Each member state has to adopt laws, regulations, and administrative provisions brought into force by the Commission to comply with the safety directive.

2. With the agreement of the Commission, a member state may introduce a new national safety rule, which requires a higher safety level than the CST defined by the agency.

3. Each member state has to maintain two organizations (a safety authority and an investigation body) with sufficient resources to conduct their tasks.

The European Railway Agency (ERA) is the community agency for railway safety and interoperability established by regulation of the European Parliament and of the Council. The ERA has a central role in the proposed harmonized rail structure and hence in ensuring rail safety as well. It has the main goal of facilitating coordination between member states and is the "force of proposals" in the rail safety field. It has to maintain and improve common European principles on safety. These common principles include:

1. the Common Safety Indicators (CSI);

2. the Common Safety Methods (CSM);

3. the Common Safety Targets (CST);

4. the common safety requirements for safety certificates and safety authorizations;

5. the safety authority for decision-making principles and safety certification process;

6. the investigating bodies in their tasks of networking.

The Commission can be mainly represented here by two main parts: the Council and the European Parliament. The European Commission has the main role of ensuring the adopting of new regulations, rules and so on, including the adoption of CST and CSM for rail transport at the European level with the main principles of opening the European rail market and harmonizing operation (Bearfield et al.2004; Bearfield et al.2005; El-Koursi et al. 2007). This task must be done in a non-discriminatory manner. From this perspective, the Commission can enforce a decision on a member state, for example on a draft national rule, if it finds that the rule is incompatible with the CSM or with achieving the CST, or that the rule constitutes a means of arbitrary discrimination or a disguised restriction on rail transport operation between member states. 


\subsubsection{Basic elements of the European Safety Management System}

A Safety Management System (SMS) is an organization's formal arrangement, through the provision of policies, resources, and processes, to ensure the safety of its work activity. An effective SMS helps the organization to identify and manage risks efficiently. It allows an organization to demonstrate its capability in achieving its safety objectives and in meeting regulatory requirements.

A crucial aspect of RU's and IM's safety management activities will be the management of interfaces. In many member states' railways, the new organizational structure will increase the number of interfaces, and hence introduce potentially new types of risks. An organization faces essentially three different types of risks to its operations:

1. Internal risks are those associated with activities and locations for which the organization is solely and wholly responsible.

2. External risks are those originating from systems, people or organizations, and processes that are wholly outside the scope of the organization's control.

3. Shared risks are risks associated with activities or locations for which there are shared responsibilities rather than sole ownership; to manage such risks the organizations have to ensure that compatible approaches are used.

\subsection{Member states' institutional framework}

In order to ensure a safe and interoperable EU railway sector, the second railway package has created a decentralized system of railway authorities covering a number of railway institutions with different roles and responsibilities. It includes today:

1. National Safety Authorities (NSAs), responsible, inter alia, for granting safety certificates to railway undertakings, and safety authorizations to infrastructure managers, and authorizing the placing in service of railway vehicles and subsystems ${ }^{36}$;

2. Notified Bodies (NoBos), responsible mainly for conformity assessment of rail vehicles and subsystems, after having verified their compliance with the relevant technical specifications for interoperability (TSIs);

3. Designated Bodies (DeBos), responsible for conformity assessment in the case of national rules which are still applicable (TSI open points, specific cases, derogations);

4. National Investigation Bodies (NIB), responsible for investigating serious railway accidents;

5. Regulatory Bodies, responsible for ensuring a fair and non-discriminatory access to the rail network and services.

\footnotetext{
36 The system constituting the rail system may be broken down into the following subsystems: (a) structural areas (infrastructure, energy, control, command and signaling, rolling stock); and (b) functional areas (traffic operation and management, maintenance, telematics applications for passenger and freight services).
} 


\subsection{Regulations on Common Safety Methods}

\subsubsection{Risk Acceptance Criteria (RAC) and Risk Acceptance Criteria of Technical System (RAC-TS)}

According to the European safety directive, the CSMs are the methods to be developed to assess whether safety targets and other safety requirements are met. It focuses on risk assessment, as this a priority in the safety directive. CSMs shall apply to any change to the railway system in a member state, as referred to in point (2) (d) of Annex III to Safety Directive 2004/49/EC, which is considered to be significant. CSM shall be applied only to assess predictively the safety of significant changes to the railway system both in EU member states and in Eurasian countries (see Fig. 6).

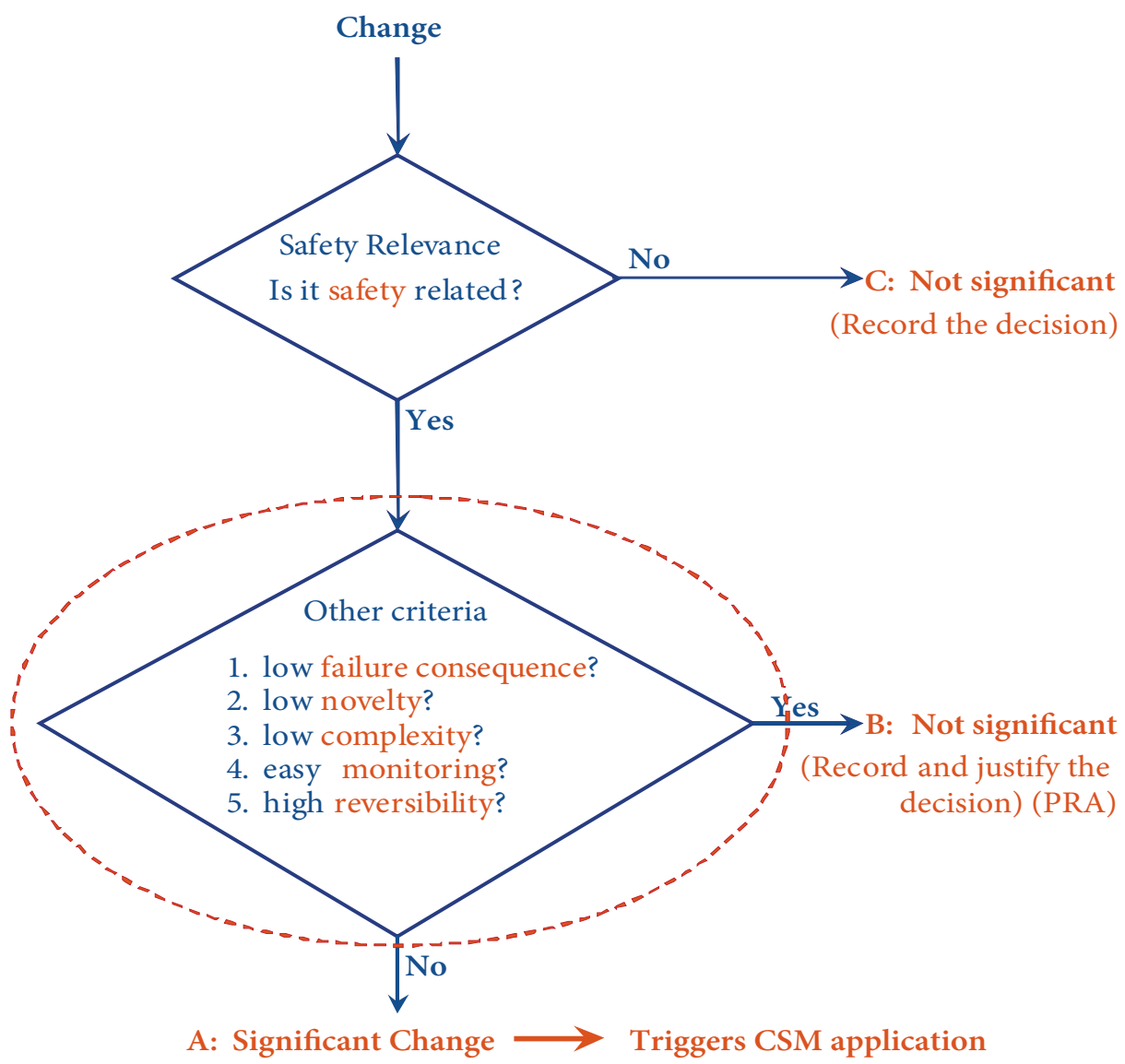

Figure 6. Initial analysis of significant change (El-Koursi et al. 2006) 
The European Regulation No 402/2013 on the common safety method for risk evaluation and assessment and repealing Regulation (EC) No 352/2009, on the $30^{\text {th }}$ of April, 2013, proposes in its annex a common risk management process and independent assessment. The risk management process shall start from a definition of the system under assessment and comprise the following activities:

a) the risk assessment process, which shall identify the hazards, the risks, the associated safety measures, and the resulting safety requirements to be fulfilled by the system under assessment;

b) demonstration of the compliance of the system with the identified safety requirements;

c) management of all identified hazards and the associated safety measures.

This risk management process is unceasing and iterative, and is depicted in Figure 7. The process ends when compliance of the system with all the safety requirements necessary to accept the risks linked to the identified hazards is demonstrated.

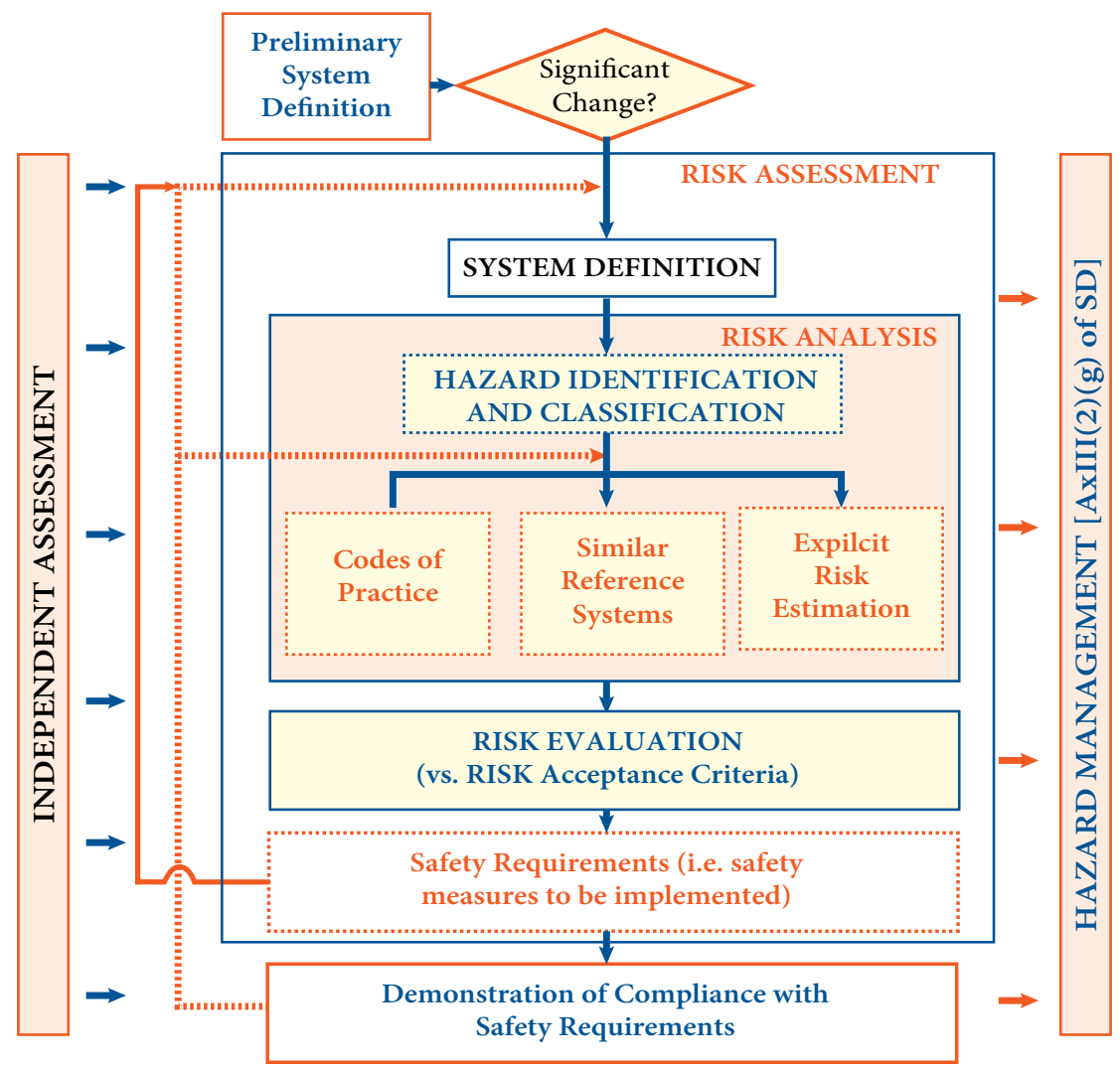

Figure 7. Risk assessment criteria of technical system approach (El-Koursi et al. 2006) 
Risk assessment is the overall iterative process that comprises:

I. System definition

II. Risk analysis that includes:

1. Hazard identification and classification

2. Three risk acceptance principles (existing safety assessment methods):

a) codes of practice;

b) similar reference systems;

c) explicit risk estimation.

III. Risk evaluation

A risk in classic theory is stated as:

$$
\text { Risk }=\text { Vulnerability } \times \text { Threat } \times \text { Impact. }
$$

Then:

Finally:

$$
\text { Vulnerability } \times \text { Threat }=\text { Probability of Risk } \text {. }
$$

$$
\text { Risk = Probability of Risk } \times \text { Impact. }
$$

Where hazards arise from failures of technical systems not covered by codes of practice or the use of a reference system, the following risk acceptance criterion shall apply for the design of the technical system: "For technical systems where a functional failure has a credible direct potential for a catastrophic consequence, the associated risk does not have to be reduced further if the rate of that failure is less than or equal to $10^{-9}$ per operating hour" (Risk Acceptance 2010).

\subsection{Applying Analytic Hierarchy Process to assess traffic safety risk of railway infrastructure}

Here, the authors present the approaching Analytic Hierarchy Process (AHP) for assessment of the risk level in railway infrastructure areas. AHP has been described in recent research as an emerging multicriteria decision-making approach to solving large, dynamic, and complex problems, which reflect real situations, such as strategic planning of management or resources, justification of introducing new technologies or determining the effectiveness of systems' operation. The application of the AHP to performance evaluation was through a case study of the Lithuanian Railways traffic safety risk. The results of the performed investigation showed that the application of the AHP method can help railway traffic control managers and decision makers effectively evaluate the railway infrastructure objects from the perspective of traffic safety risk, and make long-term strategic plans for preventing accidents on railway lines, even under difficult economic and transportation conditions. A model for assessing railway 
infrastructure objects from the perspective of traffic safety risk, developed and realized by the authors for the Lithuanian Railways' two operating lines, is presented below.

Traffic safety is one of the main problems facing road and railway operators in many countries of the world. The traffic safety situation in Lithuania, despite the progress made in 2008, is still not good enough compared to the other European Union countries. The effective control and management of railway traffic and ensuring its safety, requires a comprehensive analysis of the state of the railway infrastructure objects and systemization of the obtained data. This would help to develop urgent, effective measures to considerably reduce railway traffic safety risks (Cacciabue 2005). The component of railway infrastructure that causes many problems associated with the collisions of trains with road vehicles, and human injuries and mortalities, is the level crossing. A comprehensive analysis of level crossings was performed for a period of several years (2003 to 2011) in Australia, and the risk evaluation model ALCAM (Australian level crosssing assesment model) was suggested, and practically implemented by its governmental institutions. Experts in Great Britain also pay great attention to increasing traffic safety at railway level crossings with the help of the developed traffic safety control model ALCRM. The Safety Risk Model (SRM), which presents a quantitative investigation of the potential accidents resulting from the operation and maintenance of the Great Britain rail network is widely applied too (RSSB ... 2012). SRM comprises a total of 120 individual models, each representing a type of hazardous event. Other railway infrastructure components causing problems to specialists dealing with the problems of railway traffic safety in the Baltic States, Poland, and Finland, are railway stations, freight terminals and their sorting track yards, and pipelines (Lama et al. 2006; Sivilevičius et al. 2010).

Railway traffic safety control is aimed at protecting people, their health and wealth, as well as improving traffic conditions, reducing harmful effects of rail transport on the environment, and ensuring the realization of the general aims associated with railway traffic safety and the relationship between railway systems of various countries. The control of railway traffic safety is regulated in Lithuania by the Lithuanian law on railway traffic safety. This law defines the rights and responsibilities of the state institutions developing and implementing the policy of railway traffic safety, as well as the requirements and the rights of the managers (carriers), and the investigation and registration of traffic accidents.

The aim of this research is to present a traffic safety risk evaluation model developed by the authors with respect to various objects of the railway infrastructure based on qualitative (expert) evaluation. In the considered risk management model, it is suggested to assess the damage made by railway traffic accidents based on the criteria presented in the Lithuanian law on railway traffic safety. 
The study of Japanese scientists (Silla and Kallberg 2012) was conducted to evaluate the effect of potential risk factors such as driving without a license, alcohol use, speed, seat belt, and helmet use on fatality in motor vehicle traffic accidents. Human factors play an important role in the occurrence of railway traffic accidents too. They include the violation of traffic rules, ignorance of road signs and signals by train operators, tiredness, intoxication, etc. (Lobb 2006; Savage 2006). However, traffic safety specialists emphasize that technical factors, including the provision of fencing, pedestrian and cattle crossings, lighting and signs, visibility, etc., can also increase traffic safety (Chang et al. 2008; Olejnik 2003).

The application of multicriteria methods, especially the AHP method, largely depends on calculation of the criteria weights, based on expert evaluation (Saaty 2003). The results obtained can be used for practical purposes if expert judgments are in agreement (Szybka et al. 2011). The latter may be determined by the concordance coefficient obtained by ranking the available alternatives. The risk level estimation processing considers a possibility to apply the concordance coefficient in the cases when expert evaluation is not based on ranking. The calculations reveal the dependence of the agreement of expert estimates on a particular method used. The highest degree of agreement has been obtained by using the direct ranking method. The effect of equally assessed criteria, i.e. the tied ranks, on the concordance coefficient and thereby on the level of expert judgments' agreement is usually insignificant and cannot change the results of rating.

For the reasons discussed above, in the presented survey, the AHP method was chosen by the authors. It was applied to the analysis of the transport sector, particularly to the assessment of Lithuanian railway traffic risks.

In the railway line environment, these groups of criteria (factors) were evaluated:

1) the intensity of railway and road traffic;

2) the degree of line traffic control (controllable, semi-automatic, and fully automatic);

3) ambient conditions (rain, snow, darkness, fog, etc.); and

4) other risks.

The infrastructure of the Lithuanian Railways embraces the main lines of $2000 \mathrm{~km}$ of length, more than 500 level crossings (located at a distance of $4.2 \mathrm{~km}$ from each other), many railway stations, bridges, viaducts, several locomotive maintenance depots, and one tunnel. All objects of the railway's infrastructure are clearly defined, the comprehensive data referring to them is presented, and major criteria describing railway traffic safety are determined. The significance of these criteria is also determined, based on expert evaluation, and they are ranked according to this parameter. After evaluation of factors influence weight on the analyzed railway line accident level, the urgent measures 
to increase the traffic safety can be ranked. The authors offer the developed model for evaluating safety risks with respect to the objects of Lithuanian railway infrastructure. This model was applied on two Lithuanian real rail lines situated on the main transport corridor (the IXB trans-European corridor) to investigate the level of traffic risk and recommend vital means to improve the situation on these lines. The suggested estimation process, based on scientifically-grounded methods (Davey et al. 2008; Lin 2010; McCollister and Pflaum 2007; Podofillini et al. 2006; Shedden et al. 2011), could also be used for assessing and managing traffic safety on the railways infrastructure objects of various Eurasian countries.

\subsubsection{Railway infrastructure and identification of risk objects}

The operator of the Lithuanian railway infrastructure is the state-owned company LG, which manages and regulates the traffic in the entire railway network. The railway sidings are private. Railway traffic is controlled by the State Inspection of Railways subordinate to the Ministry of Transport.

The investigation and assessment of traffic safety risks associated with railway infrastructure were performed in three stages:

1. The initial stage includes the collection (registration) and organization of data on the objects of railway infrastructure, identification of threats which may result in traffic accidents, expert evaluation of possible damage, the collection of data on the risks associated with the infrastructure objects, and determination of the significance of risk factors.

2. The railway traffic risk analysis stage is when the risk level of an object or a set of objects, chosen based on particular criteria, taking into account the registered risk factors of the considered object or set of objects, is considered.

3. The traffic risk management stage covers the selection of the required or recommended measures aimed at reducing risks associated with a particular object or a set of objects, selected based on particular factors.

At the initial stage of analysis, the data on the objects of the Lithuanian railway infrastructure presenting risks to traffic safety are collected. The risks presented by the following objects of railway infrastructure to railway traffic safety are considered and assessed by the evaluation model:

1) rolling stocks;

2) rails and automatic switches;

3) railway buildings;

4) level crossings;

5) signaling systems and automatic devices;

6) railway stations and terminals. 
The main objective of railway traffic safety risk evaluation is to look at the most basic railway infrastructure component - the railway line. The railway network of the state consists of railway lines, which form the primary chain of the automatic and signaling system of traffic management.

Traffic safety on the railway line depends on certain general factors, as follows:

1) type of the railway line (single/double track);

2) availability of automatic train traffic control devices;

3) the conditions of track repair performance, with the traffic stopped or active;

4) operational (actual average) speed of the trains;

5) actual number of pairs of trains, running along the railway line per day;

6) the type of the traffic block-system (automatic or semi-automatic system);

7) type of the railway line (crossing-or not-any settlements);

8) the distance to the closest residential building;

9) type of the railway line (passing-or not-any stations);

10) fencing of the railway line;

11) the number of level crossings;

12) visibility of level crossings in both directions;

13) level crossing lighting (present or not present);

14) the number of automatic switches on the railway line;

15) the number of bridges;

16) the number of animal crossings;

17) the number of viaducts and overpasses;

18) the number of viaducts over water;

19) a description of the track largest grade (slope) of the railway line;

20) the smallest radius and length of a horizontal curve;

21) geometric errors of the gauge;

22) the highest super-elevation of the rails.

The survey of experts' opinions (specialists in railway traffic safety and train maintenance) allowed the authors to determine the main risk factors for railway line traffic as follows:

1) single-track or double-track railway;

2) geometric errors in the railway track gauge;

3) the number of pairs of trains per day;

4) type and number of level crossings;

5) category of level crossing (intensity of road and train traffic);

6) availability of automatic control devices of train traffic;

7) the largest track grade and the track's smallest horizontal curve. 


\subsubsection{Identification of traffic accident threats on railways}

The analysis of the data on railway traffic safety risks allowed the authors to identify the main threats as follows:

1) the collision of trains;

2) train derailing;

3) the collision of rolling stock;

4) the derailing of rail vehicle;

5) the collision of rail vehicle and road vehicles at level crossings;

6) running of rail vehicle vehicles over the people at level crossings;

7) the collision of rail vehicle and some foreign bodies at level crossings;

8) the collision of rail vehicle and people in the area of the railway and its equipment (buildings);

9) the collision of rail vehicle and the objects of railway infrastructure;

10) the collision of rail vehicle and other objects;

11) fire in the rail vehicle;

12) signal passing at danger (SPAD);

13) breakage of the rail vehicle wheels;

14) breakage of the rail vehicle wheelsets;

15) spontaneous uncoupling of automatic train carriage coupling;

16) rail breakage;

17) geometric gauge damage;

18) signaling error (erroneous train route design);

19) breakages in signaling, communication, contact systems and power equipment;

20) faults in other engineering equipment.

The threats to railway traffic are constantly revised during the operation of trains and other infrastructure objects. Threats are identified by performing the following actions:

1. While investigating railway traffic accidents, it should be determined if the accident was caused by violation of a law regulating railway traffic safety.

2. The investigator of railway safety risks, having found the cause of the traffic accident, should check if this cause had already been registered as a risk factor in the traffic safety evaluation model.

To determine railway traffic safety risks, the potential threats should be determined (Rheinberger et al. 2009). It is found taking into account the factors given below:

1. human safety.

2. direct and indirect financial losses due to:
a) infrastructure damage;
b) damage to the rail vehicle;
c) harm to the environment;
d) train delay. 
To perform the analysis of railway traffic safety risks based on the suggested model, taking into account railway infrastructure objects, the following expert information is required:

1. Types of objects

2. Threats typical of a particular object

3. Factors, increasing the weight of threat criteria

4. Relative values of factors, increasing the weight of threat criteria

5. Factors, decreasing the weight of threat criteria (control measures are offered)

6. The level of damage caused by the realized threat

\subsubsection{The determination of the railway infrastructure objects risk model}

The application of the created model was demonstrated by considering two railway lines, representing Lithuanian Railways infrastructure. Their brief description is given below.

The first considered Lithuanian railway line is "Livintai-Gaižiūnai."

1) Railway type: a single-track railway

2) Railway track gauge: $1520 \mathrm{~mm}$

3) Distance: $12 \mathrm{~km}$

4) Automatic block system

5) Type of signalling: interlocking system

6) Communication system: analogue, digital

7) Railway traffic intensity: 63 pairs of trains per day

8) Allowable speed on the railway line for freight/ passenger trains: $90 / 120 \mathrm{~km} / \mathrm{h}$

9) The number of level crossings:1unit

10) The type of level crossings: 1 unregulated level crossing

11) Road traffic intensity at the level crossing: 12 vehicles/day

12) The number of switches on the railway line (without railway station switches): no switches

13) The smallest radius of the road curve on the railway line: $833 \mathrm{~m}$

14) The largest track on the railway line: $7.9 \%$.

The second considered Lithuanian railway line is "Kaišiadorys-Pravieniškès."

1) Railway type: a double-track railway

2) Railway track gauge: $1520 \mathrm{~mm}$

3) Distance: $16 \mathrm{~km}$

4) Automatic block system

5) Type of signalling: interlocking system

6) Communication system: analogue, digital 
7) Railway traffic intensity: 43 pairs of trains per day

8) Allowable speed on the railway line for freight/ passenger trains:

a) Even route: $80 / 120 \mathrm{~km} / \mathrm{h}$

b) Odd route: $90 / 120 \mathrm{~km} / \mathrm{h}$

9) The number of level crossings: 1 unit

10) The type of level crossings: 1 unregulated level crossing

11) Road traffic intensity at the level crossing: 1533 vehicles/day

12) The number of switches on the railway line (without railway station switches): no switches

13) The smallest radius of the road curve on the railway line:

a) Even route: $850 \mathrm{~m}$

b) Odd route: $1373 \mathrm{~m}$

14) The largest track on the railway line:

a) Even route: $5.8 \% \mathrm{o}$

b) Odd route: $5.5 \% \mathrm{o}$

\subsubsection{Threats deliberated in the risk management model}

Three common threats to any railway line were chosen to reveal the operation of the risk estimation model:

1. Human injury (T1)

2. Derailment (T2)

3. The collision of rail vehicle (T3)

For each of these three threats, the factors increasing the weight of criteria were identified.

The first threat, T1. The factors increasing the weight of the threat "Human injury" criteria:

1) T1F1: High allowable train speed (more than $100 \mathrm{~km} / \mathrm{h}$ )

2) T1F2: Intense railway traffic (more than 50 pairs of trains per day on a doubletrack and more than 24 pairs of trains on a single-track railway)

3) T1F3: The railway in the state of track repair (with traffic stopped)

4) T1F4: The railway in the state of track repair (with traffic active)

5) T1F5: Regulated level crossing with low intensity road traffic (up to 500 vehicles per day)

6) T1F6: Unregulated level crossing with low intensity road traffic (up to 500 vehicles per day)

7) T1F7: Regulated level crossing with high intensity road traffic (more than 500 vehicles per day)

8) T1F8: Unregulated level crossing with high intensity road traffic (more than 500 vehicles per day) 
The second threat, T2. The factors increasing realization weight of the threat "Derailment" criteria were identified.

1) T2F1: High allowable maximum speed (more than $100 \mathrm{~km} / \mathrm{h}$ )

2) T2F2: Intense railway traffic (more than 50 pairs of trains per day on a doubletrack and more than 24 pairs of trains on a single-track railway)

3) T2F3: The railway in the state of track repair (with traffic active)

4) T2F4: Passing a switch (switches)

5) T2F5: Railway curves of small radius (up to $700 \mathrm{~m}$ )

6) T2F6: Railway track grade (a large grade of more than $8 \%$ and length of more than $2 \mathrm{~km}$ )

7) T2F7: Irregular straight railway track gauge (lower than $1517 \mathrm{~mm}$ or higher than $1525 \mathrm{~mm}$ )

8) T2F8: No automatic railway traffic regulating devices (on the passed railway line)

9) T2F9: The ambient temperature $\left(-30^{\circ} \mathrm{C}\right.$ and lower, or $+30^{\circ} \mathrm{C}$ and higher).

The third threat, T3. The factors, increasing the realization weight of the threat "Collision of rail vehicle" criteria were identified.

1) T3F1: The use of automatic block system on the railway line

2) T3F2: The railway in the state of track repair with traffic stopped, when an even train is allowed to run on the odd track or vice versa

3) T3F3: A single-track railway

4) T3F4: The use of a parallel gauge (European and wide track gauges) on the railway line

5) T3F5: High allowable maximum speed (more than $100 \mathrm{~km} / \mathrm{h}$ )

6) T3F6: Intense railway traffic (more than 50 pairs of trains per day on a doubletrack and more than 24 pairs of trains on a single-track railway)

7) T3F7: Passing a switch (switches)

8) T3F8: No automatic railway traffic regulating devices (on the railway line)

\subsubsection{Evaluating the factors, which increase the weight of the threat criteria, by using the AHP method}

Ranking is not the only method of comparing various objects. Experts may evaluate the objects (or the factors describing them) in the units of measurement of a particular scale, as well as in percent, or in any system of points. They may also determine the values of the criterion weights by the method of pairwise comparison. In this case, the sum of the criterion weights should be equal to one. If we wish to apply the concordance coefficient $W$ for establishing the level of consistency of experts' judgements, any assessment of the objects should be transformed into ranking. This is not difficult to do 
because any method shows the significance of the objects as well.

For quantitative evaluation of the weights (significance) of the criteria describing the objects, the AHP (Analytic Hierarchy Process) pairwise comparison method was applied by Saaty (1980) and later widely used by many other scientists (Lin 2010). Experts compare all estimated factors (criteria) in pairs.

The pairwise comparison matrix is:

$$
\begin{gathered}
A=\left\{\begin{array}{cccc}
1 & \frac{w_{1}}{w_{2}} & \ldots & \frac{w_{1}}{w_{m}} \\
\frac{w_{2}}{w_{1}} & 1 & \ldots & \frac{w_{2}}{w_{m}} \\
\ldots & \ldots & \ldots \\
\ldots & \ldots & \ldots \\
\frac{w_{m}}{w_{1}} & \frac{w_{m}}{w_{2}} & \ldots & 1
\end{array}\right\} ; \\
a_{i i}=1 ; a_{i j}=\frac{1}{a_{j i}} \text { and } a_{j i} \neq 0 .
\end{gathered}
$$

where: $m$ is the number of compared factors (criteria).

T. Saaty devised a consistency test to distinguish the consistent comparisons (with acceptable deviations) from the inconsistent comparisons (with unacceptable deviations). The consistency test involves the use of a consistency ratio, $\mathrm{CR}=(\lambda \max -\mathrm{n})$ / $(\mathrm{n}-1) / \mathrm{RI}$, where RI is a random index given in the tables (Saaty 1980). If the value CR 0.1, the decision maker has to redo the pairwise comparison matrix.

An example of determining the values of the weights of threat criteria, using the above-mentioned T. Saaty method, and the filled in questionnaire of pairwise comparison of criteria obtained from the experts, are shown in Table 8, in Table 10 and in Table 12.

Applying the T. Saaty's AHP pairwise comparison method, the level of consistency of judgements is determined for each expert. In this case, the level of consistency of judgements of a group of experts based on the concordance coefficient was determined by calculating the T. Saaty weights of the criteria and ranking them according to decreasing weights. The method enables us to determine the level of judgements' consistency for an expert. The consistency of 20 experts' judgements was acceptable because the concordance coefficient was less than 0.1 . 
To evaluate the factor) increasing the weight of the threat criteria, the method of pairwise comparison was used. During the analysis, the factors increasing the weight of each threat criteria, were compared with each other against the 9-point scale. Performing risk analysis of traffic on Lithuanian Railways, a questionnaire survey of 12 experts of railway traffic control and management and four staff members (decision makers) of the state company "Lithuanian Railways" was made. When the data elicited from experts were processed and the consistency of experts' judgements was validated by methods presented in the papers of Sivilevičius et al. (2010), the comparison matrices and values of the threat-increasing factors were obtained in this research work.

\subsubsection{Risk threat "human injury"}

The values of the comparison matrix's factors increasing the weight of the threat "human injury" are presented in Table 8.

Table 8. The comparison matrix of the factors increasing the threat "human injury" (threat T1)

\begin{tabular}{|c|c|c|c|c|c|c|c|c|}
\hline \multirow{2}{*}{$\begin{array}{l}\text { Factors increasing threat } \\
\text { realization }\end{array}$} & \multicolumn{8}{|c|}{ Values of comparable coefficients } \\
\hline & T1F1 & T1F2 & T1F3 & T1F4 & T1F5 & T1F6 & T1F7 & T1F8 \\
\hline $\begin{array}{l}\text { T1F1. High allowable } \\
\text { maximum speed } \\
\text { (more than } 100 \mathrm{~km} / \mathrm{h} \text { ) }\end{array}$ & 1 & $1 / 2$ & $1 / 3$ & $1 / 6$ & $1 / 3$ & $1 / 5$ & $1 / 4$ & $1 / 8$ \\
\hline
\end{tabular}

T1F2. Intense railway traffic (more than 50 pairs of trains per day on a double-track and more than 24 pairs of trains on a single-track railway)

T1F3. The railway in the state of track repair (with traffic stopped)

$\begin{array}{llllllll}2 & 1 & 1 / 2 & 1 / 5 & 1 / 2 & 1 / 4 & 1 / 3 & 1 / 6\end{array}$

1F4. The railway in the state of track repair (with traffic active)

T1F5. Regulated level crossing with low intensity road traffic of up to 500 vehicles per day

T1F6. Unregulated level crossing with low intensity road traffic of up to 500 vehicles per day

T1F7. Regulated level crossing with high intensity road traffic of more than 500 $\begin{array}{llll}4 & 3 & 1 / 5 & 1 / 4\end{array}$ $1 / 6$

$21 / 2$

$5 \quad 1 / 4$
vehicles per day

T1F8. Unregulated level crossing with high intensity road traffic of more than 500

$6 \quad 5$

6

1

4

$\begin{array}{lll}2 & 4 & 1\end{array}$

3

$\begin{array}{llllllll}3 & 2 & 1 / 2 & 1 / 4 & 1 & 1 / 4 & 1 / 2 & 1 / 8\end{array}$
vehicles per day 
Based on the data of the comparison matrix presented in Table 1, and the validation of consistency of the compared coefficients, the weight values of the factors describing the threat of "human injury" are given in Table 9.

Table 9. The weight values of the factors increasing the threat "human injury" (threat T1)

\begin{tabular}{cc} 
Threat-increasing factors & Weight value \\
T1F1. High allowable maximum speed (more than $100 \mathrm{~km} / \mathrm{h}$ ) & 0.021 \\
\hline $\begin{array}{c}\text { T1F2. Intense railway traffic (more than } 50 \text { pairs of trains per day on a } \\
\text { double-track and more than } 24 \text { pairs of trains on a single-track railway) }\end{array}$ & 0.047 \\
\hline $\begin{array}{c}\text { T1F3. The railway line in the state of track repair (with train traffic stopped) } \\
\text { T1F4. The railway line in the state of track repair (with train traffic active) }\end{array}$ & 0.077 \\
\hline $\begin{array}{c}\text { T1F5. Regulated level crossing with low intensity road traffic of up } \\
\text { to } 500 \text { vehicles per day }\end{array}$ & 0.311 \\
\hline $\begin{array}{c}\text { to } 500 \text { vehicles per day } \\
\text { than } 500 \text { vehicles per day }\end{array}$ & 0.033 \\
\hline $\begin{array}{c}\text { T1F7. Regulated level rossing with high intensity road traffic of more } \\
\text { than } 500 \text { vehicles per day }\end{array}$ & 0.101 \\
\hline \begin{tabular}{l} 
T1F8. Unregulated level crossing with high intensity road traffic of more \\
\hline
\end{tabular} & 0.064 \\
\hline
\end{tabular}

\subsubsection{Risk threat "derailment"}

The values of the comparison matrix's factors increasing the weight of the threat "derailment" criteria were estimated. As was gathered according to AHP analyses, the threat factors T1F4 and T1F8 are the most determining factors of the weight of threat T1 "human injury" criteria. Based on the comparison matrix of the coefficients given, and the validation of the presented data, the values of the factors increasing the weight of the threat of derailment criteria, are obtained. They are presented in Table 10.

Table 10. The weight values of the factors increasing the threat "derailment" (threat T2)

\section{Threat-increasing factors}

T2F1. High allowable maximum speed (more than $100 \mathrm{~km} / \mathrm{h}$ )

T2F2. Intense train traffic (more than 50 pairs of trains per day on a doubletrack and more than 24 pairs of trains on a single-track railway)

T2F3. The railway line in the state of track repair (with train traffic active)

T2F4. Passing a switch (switches)

T2F5. Railway track curves of small radius (up to $700 \mathrm{~m}$ )

T2F6. Railway track grade (a large grade of more than $8 \%$ and length of more than $2 \mathrm{~km}$ )

T2F7. Irregular straight railway track gauge

(lower than $1517 \mathrm{~mm}$ or higher than $1525 \mathrm{~mm}$ )

T2F8. No automatic railway traffic regulating devices (on the passed railway line)
Weight value

0.031

0.026

0.220

0.120

0.112

0.029

0.346

0.068

T2F9. The ambient temperature $\left(-30^{\circ} \mathrm{C}\right.$ and lower or $+30^{\circ} \mathrm{C}$ and higher $)$ 
As is seen in Table 10, the threat factors T2F3 and T2F7 are the most determining factors of the weight of the threat T2 "derailment" criteria.

\subsubsection{Risk threat "collision of rail vehicle"}

The values of the comparison matrix's factors increasing the weight of the threat "collision of rail vehicle" criteria, were estimated by the realization of the comparison matrix. Based on the solved comparison matrix of the coefficients and the validation of the presented data, the values of the risk factors increasing the weight of the threat "collision of rail vehicle" are obtained. They are presented in Table 11.

Table 11. The weight values of the factors increasing the threat "collision of rail vehicle" (threat T3)

Threat-increasing factors

T3F1. The use of automatic block system on the railway line

T3F2. The railway in the state of track repair

(with train traffic stopped, when an even train is allowed to run on the odd track, or vice versa)

T3F3. A single-track railway

T3F4. The use of a parallel gauge

(European and wide track gauges) on the railway line

T3F5. High allowable maximum speed (more than $100 \mathrm{~km} / \mathrm{h}$ )

T3F6. Intense railway traffic (more than 50 pairs of trains per day on a double-track and more than 24 pairs of trains on a single-track railway)

T3F7. Passing a switch (switches)
Weight value

0.079

0.224

0.184

0.239

0.037

0.076

0.113

T3F8. No automatic train traffic regulating devices (on the passed railway line)

As is seen in Table 11, the threat factors T3F2 and T3F4 are the most determining factors of the weight of the threat T3 "collision of rail vehicle" criteria.

\subsubsection{Risk assessment of the threat "collision of rail vehicle" in real lines of Lithuanian Railways}

The results of the weight of the threat "collision of rail vehicle" criteria obtained for the considered infrastructure objects (railway lines) are presented in Table 12. 
Table 12. Assessment of the weight of the threat "collision of rail vehicle" criteria on the railway lines

\begin{tabular}{|c|c|c|c|c|}
\hline \multirow[b]{2}{*}{ Threat-increasing factor } & \multirow[b]{2}{*}{$\begin{array}{l}\text { Weight of } \\
\text { criteria }\end{array}$} & \multicolumn{3}{|c|}{ Infrastructure line (section) } \\
\hline & & $\begin{array}{l}\text { "Livintai- } \\
\text { Gaižiū- } \\
\text { nai" }\end{array}$ & $\begin{array}{l}\text { "Kaišiadorys- } \\
\text { Pravieniškès" }\end{array}$ & $\begin{array}{l}\text { “Kaišiadorys- } \\
\text { Pravieniškès" } \\
\text { (railway under } \\
\text { track repair) }\end{array}$ \\
\hline $\begin{array}{l}\text { T3F1. The use of automatic } \\
\text { block system on the railway line }\end{array}$ & 0.079 & 0.079 & 0.079 & 0.079 \\
\hline $\begin{array}{l}\text { T3F2. The railway in the state } \\
\text { of track repair (with traffic } \\
\text { stopped, when an even train is } \\
\text { allowed to run on the odd track } \\
\text { or vice versa) }\end{array}$ & 0.224 & - & - & 0.224 \\
\hline T3F3. A single-track railway & 0.184 & 0.184 & - & - \\
\hline $\begin{array}{l}\text { T3F4. The use of a parallel } \\
\text { gauge (European and wide track } \\
\text { gauges) on the railway line }\end{array}$ & 0.239 & - & - & - \\
\hline $\begin{array}{l}\text { T3F5. High allowable } \\
\text { maximum speed (more than } \\
100 \mathrm{~km} / \mathrm{h})\end{array}$ & 0.037 & 0.037 & 0.037 & 0.037 \\
\hline $\begin{array}{l}\text { T3F6. Intense train traffic (more } \\
\text { than } 50 \text { pairs of trains per day } \\
\text { on a double-track and more } \\
\text { than } 24 \text { pairs of trains on a } \\
\text { single-track railway) }\end{array}$ & 0.076 & 0.076 & - & - \\
\hline $\begin{array}{l}\text { T3F7. Passing a switch } \\
\text { (switches) }\end{array}$ & 0.113 & - & - & - \\
\hline $\begin{array}{l}\text { T3F8. No automatic railway } \\
\text { traffic regulating devices (on } \\
\text { the passed railway line) }\end{array}$ & 0.048 & 0.048 & - & - \\
\hline $\begin{array}{l}\text { The numerical value of threat } \\
\text { weight of criteria }\end{array}$ & 1.0 & 0.424 & 0.116 & 0.340 \\
\hline $\begin{array}{c}\text { Threat realization weight of } \\
\text { criteria }\end{array}$ & - & Medium & Low & Medium \\
\hline
\end{tabular}

The potential damage of the threat "collision of rail vehicle" was estimated as large because it meets the catastrophe criteria. Having assessed the weight of the threat criteria, the authors obtained the values of the threat risk, which are given in Table 13. 
Table 13. Assessment of the threat "collision of rail vehicle" risk level

\begin{tabular}{cccc} 
Name & “Livintai- & \multicolumn{2}{c}{ Railway line } \\
Gaižiūnai" & $\begin{array}{c}\text { "Kaišiadorys- } \\
\text { Pravieniškès" }\end{array}$ & $\begin{array}{l}\text { "Kaišiadorys-Pravieniškès" } \\
\text { (railway under track repair) }\end{array}$ \\
\hline Threat & Medium & Low & Medium \\
\hline Damage & High & High & High \\
\hline Risk & High & Medium & High \\
\hline
\end{tabular}

By calculating the traffic risk level of the particular threats on the particular railway lines, the total risk of an object can be assessed. The comparative analysis of the risk level on the railway lines "Livintai-Gaižiūnai" and "Kaišiadorys-Pravieniškè" not during the track repair is presented Table 14.

Table 14. Comparison of traffic risk levels of two Lithuanian Railway lines

\begin{tabular}{ccc} 
Risk of threat & \multicolumn{2}{c}{ Railway line } \\
& "Livintai-Gaižiūnai" & "Kaišiadorys-Pravieniškès" \\
\hline Risk of the threat "human injury" & Low & Medium \\
\hline Risk of the threat "derailment" & Low & Low \\
\hline $\begin{array}{c}\text { Risk of the threat "Collision } \\
\text { of rail vehicle" }\end{array}$ & High & Medium \\
\hline $\begin{array}{c}\text { Total risk (determined based on } \\
\text { the highest risk level) }\end{array}$ & High & Medium \\
\hline
\end{tabular}

Finally, as is seen in Table 14, the risk of the threat "Derailment" has the lowest level on both analyzed railway lines.

\subsubsection{Discussion and conclusions}

The authors developed this model of railway traffic risk management, ocusing on the objects of railway infrastructure, which may be used by railway managers for improving traffic safety strategies, for establishing the priority of the required measures, and for their correction.

The suggested railway traffic risk management model provides information about the particular factors causing traffic risks, which would allow for identification of the areas or objects to be improved in order to increase railway traffic safety. The suggested railway traffic risk assessment model allows for the ranking of basic railway infrastructure objects such as railway lines, according to their risk to traffic safety, and helps to determine the "weakest points" and to plan the organizational measures required for eliminating the threats. 
First, all infrastructure objects presenting considerable risk to railway traffic according to the results obtained by using the created model, were put in the required order. Then, the level of risk of all the objects was reduced to the medium and finally to the low level.

The analysis of the threat "human injury" has shown that the factor T1F8, associated with unregulated level crossing with high intensity road traffic of more than 500 vehicles per day on the estimated railway line, highly increases the weight of the considered threat realization criteria. The elimination of this factor would allow traffic accident threats to be reduced to the "low" level, thereby decreasing the risk of the threat "human injury" to the "low" level.

\subsection{Demonstration of compliance with safety requirements}

This demonstration shall be carried out by each of the players responsible for fulfilling the safety requirements. The approach chosen for demonstrating compliance with the safety requirements, as well as the demonstration itself, shall be independently assessed by an assessment body. Any inadequacy of safety measures expected to fulfil the safety requirements, or any hazards discovered during the demonstration of compliance with the safety requirements shall lead to reassessment and evaluation of the associated risks. The new hazards shall be registered in the hazard record.

\subsubsection{Existing principles and techniques, from CENELEC 50126 standards}

The main standard in use across the European community which describes risk and reliability assessment is EN50126: 'Railway Applications - the specification and demonstration of Reliability, Availability, Maintainability and Safety (RAMS).' The standard gives examples of some risk acceptance principles and defines a comprehensive set of tasks for the different phases of a generic life cycle for a total rail system. However, EN50126 has evolved from the perspective of adopting new systems in the railway environment (for example, a new interlocking system, or new rolling stock). All of the techniques described in EN50126 are potentially relevant and usable. Table 15 presents tool and techniques to assist organizations in meeting the requirements and similarly, Table 16 has been produced to map the safety tools and techniques to each step of the CST proposed for risk assessment.

Investigation of accidents. The purpose of investigations should be to make safety recommendations for railway operators in the Europe-Asia corridor based on the findings of the investigations, in order to prevent accidents and incidents in the future and improve railway safety in the entire transcontinental land bridge/ corridors. 
Table 15. Mapping of safety methods to railway system life cycle stages (Impact Assessment 2013)

\section{Applicability of safety tools/ techniques}

Failure Initiative Design $\quad \begin{gathered}\text { Cons- } \\ \text { truction }\end{gathered} \quad \begin{gathered}\text { Exploitation } \\ \text { Operation Maintenance }\end{gathered}$

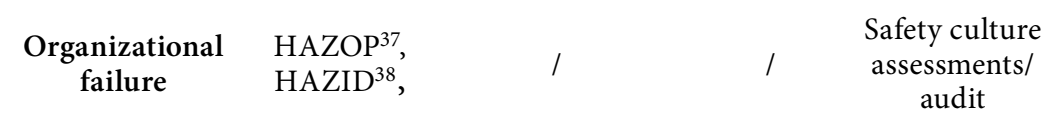

FTA $^{39}$, event tree

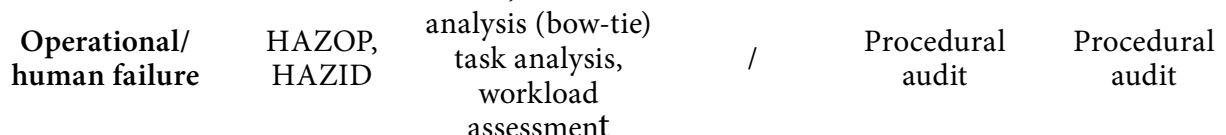

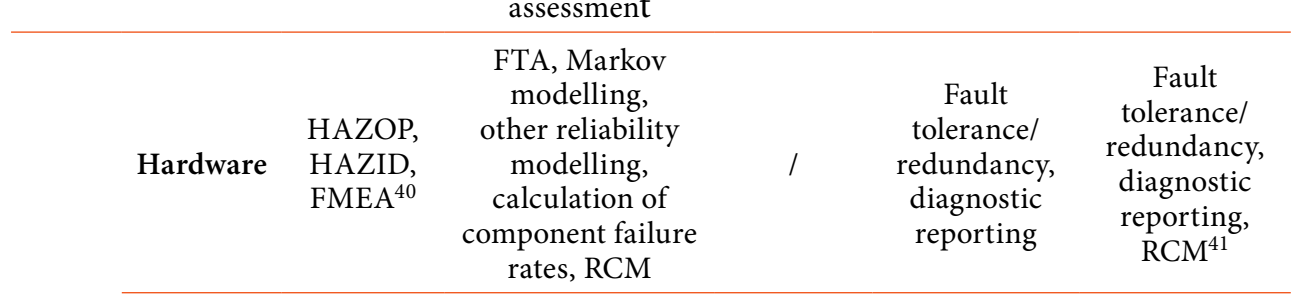

\begin{tabular}{|c|c|c|c|c|c|}
\hline Software & $\begin{array}{c}\text { HAZOP, } \\
\text { HAZID, } \\
\text { FMEA }\end{array}$ & $\begin{array}{l}\text { FTA, SIL }{ }^{42} \text { failure } \\
\text { rate estimates }\end{array}$ & I & $\begin{array}{c}\text { Fault } \\
\text { tolerance/ } \\
\text { redundancy, } \\
\text { diagnostic } \\
\text { reporting }\end{array}$ & $\begin{array}{c}\text { Fault } \\
\text { tolerance/ } \\
\text { redundancy, } \\
\text { diagnostic } \\
\text { reporting, } \\
\text { RCM }\end{array}$ \\
\hline
\end{tabular}

\footnotetext{
${ }^{37}$ Hazard and Operability Analysis

${ }^{38}$ Hazard and Operability Study

39 Fault Tree Analysis

${ }^{40}$ Failure Mode and Effect Analysis

${ }^{41}$ Reliability Centred Maintenance

${ }^{42}$ Safety Integrity Level
} 
Table 16. Mapping of safety methods to risk assessment activities (Impact Assessment 2013)

\begin{tabular}{|c|c|c|c|c|c|}
\hline \multicolumn{6}{|c|}{ Applicability of safety tools/ techniques } \\
\hline & ailure & $\begin{array}{l}\text { Hazard identifi- } \\
\text { cation }\end{array}$ & Risk analysis & Risk evaluation & $\begin{array}{c}\text { Risk reduction, } \\
\text { control and mo- } \\
\text { nitoring }\end{array}$ \\
\hline \multicolumn{2}{|c|}{$\begin{array}{l}\text { Organizational } \\
\text { failure }\end{array}$} & HAZOP, HAZID & / & / & $\begin{array}{l}\text { Safety culture } \\
\text { assessments/ } \\
\text { audit }\end{array}$ \\
\hline \multicolumn{2}{|c|}{$\begin{array}{l}\text { Operational/ } \\
\text { human failure }\end{array}$} & HAZOP, HAZID & $\begin{array}{l}\text { FTA, event tree } \\
\text { analysis } \\
\text { (bow-tie) }\end{array}$ & $\begin{array}{l}\text { Task analysis, } \\
\text { workload } \\
\text { assessment, } \\
\text { HEART }^{43}\end{array}$ & Procedural audit \\
\hline \multirow{2}{*}{ 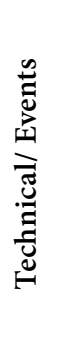 } & Hardware & $\begin{array}{c}\text { HAZOP, HAZID, } \\
\text { FMEA }\end{array}$ & $\begin{array}{l}\text { FTA, Markov } \\
\text { modelling, } \\
\text { other reliability } \\
\text { modelling }\end{array}$ & $\begin{array}{l}\text { Calculated } \\
\text { component } \\
\text { failure rates }\end{array}$ & $\begin{array}{l}\text { Fault tolerance/ } \\
\text { redundancy, } \\
\text { diagnostic } \\
\text { reporting, } \\
\text { RCM }\end{array}$ \\
\hline & Software & $\begin{array}{c}\text { HAZOP, HAZID, } \\
\text { FMEA }\end{array}$ & FTA & $\begin{array}{l}\text { SIL failure rate } \\
\text { estimates }\end{array}$ & $\begin{array}{l}\text { Fault tolerance/ } \\
\text { redundancy, } \\
\text { diagnostic } \\
\text { reporting }\end{array}$ \\
\hline
\end{tabular}

\subsubsection{Railway safety policy in Asian countries}

Unlike the European Union, Asian countries, collectively, are yet to introduce Common Safety Methods or Indexes or Criteria (CSM, CSI, CSC) for the Trans-Asian Railways or the railways that cross into each other's boundaries. However, Asian countries individually have safety management systems, and composite safety indexes which are managed by bodies or organizations that have been formed with a focus on common safety and security of railways in their countries.

The International Transport Workers' Federation (ITF), an international trade union of transport workers runs certain projects in the Asia-Pacific region. One such project is on organizing strong railway unions and networks in South Asia and Southeast Asia.

The project observes that restructuring in the railway industry in most of the countries of South and Southeast Asia is at various stages of implementation and completion.

\footnotetext{
${ }^{43}$ Human Error Assessment and Reduction Technique
} 
Workers and unions are facing major changes to their working conditions, including increased work intensity, decreased job security, and lower job satisfaction. Developing alternatives to neoliberal transport restructuring, such as quality public services for railway workers and passengers is one of the objectives of the project. ITF's railway safety project in India is focused on enhancing safety policies and implementation of safe working practices.

\subsubsection{Chinese Railways safety policies}

\section{Safety Management Architecture for China Railway}

In a research publication on the railway Safety Management System (SMS) in China, five common elements involved in risk-based SMS are suggested. Organization fundamentals and process fundamentals compose the basic requirements for the duty holders, who should clearly define the safety responsibilities of all relevant positions, and establish proper safety reporting mechanisms. These duty holders should also maintain scientific processes for planning, evaluating, recording, and reviewing safety-related work to make hazards traceable. On the basis of these processes, a whole set of hazard identification and analysis technologies can be introduced as specific measures to instantiate the process at the bottom. As the consequences of these hazards are quantified, methodologies of assessing and controlling risks will be brought into the specific product and application development; at the same time, relevant quality management and process assurance systems will be implemented with the evidences supported by safety regulations. But above all these things, a unified and unambiguous safety principle will give an invisible and formative guidance to these activities above, during each step of the system's life cycle. ${ }^{44}$

In the Chinese railway industry, the regulation and laws have perfectly defined the responsibilities of all the participants' roles, and have standardized most procedures for practitioners, even supervisors. In order to ensure the continuity of safety management and the adoption of the technology at the same time, the research publication considers it necessary to plug the risk-based Plan, Do, Check and Act Principle (PDCA) into existing safety laws and regulations for organization and process aspects, and define safety principles (see Table 17 and Figure 8).

In this way, guaranteeing systematic safety depends on indicators assigned by risk allocation.

44 "Research on Safety Management System for China Railway", by Tao Tang, Chao Li and, Ru Niu, State Key Laboratory of Rail Traffic Control and Safety, Beijing Jiaotong University, China 
Table 17. PDCA for railway safety management (Tao Tang et al. 2009; El-Koursi et al. 2007)

\section{Deming Cycle}

\section{Safety Management System}

Nature and scope of duty holder's business Safety policy

Plan

\begin{tabular}{cc}
\hline & Risk identification \\
\cline { 2 - 2 } Risk & Risk control \\
\cline { 2 - 2 } management & Safety assurance
\end{tabular}

Do

Organization structure and responsibilities

Competence, training and qualification

Incident and accident reporting and learning

Check

$$
\text { Emergency management }
$$

Safety communication and information integrity

Act Monitoring, auditing, corrective measures, and annual reports

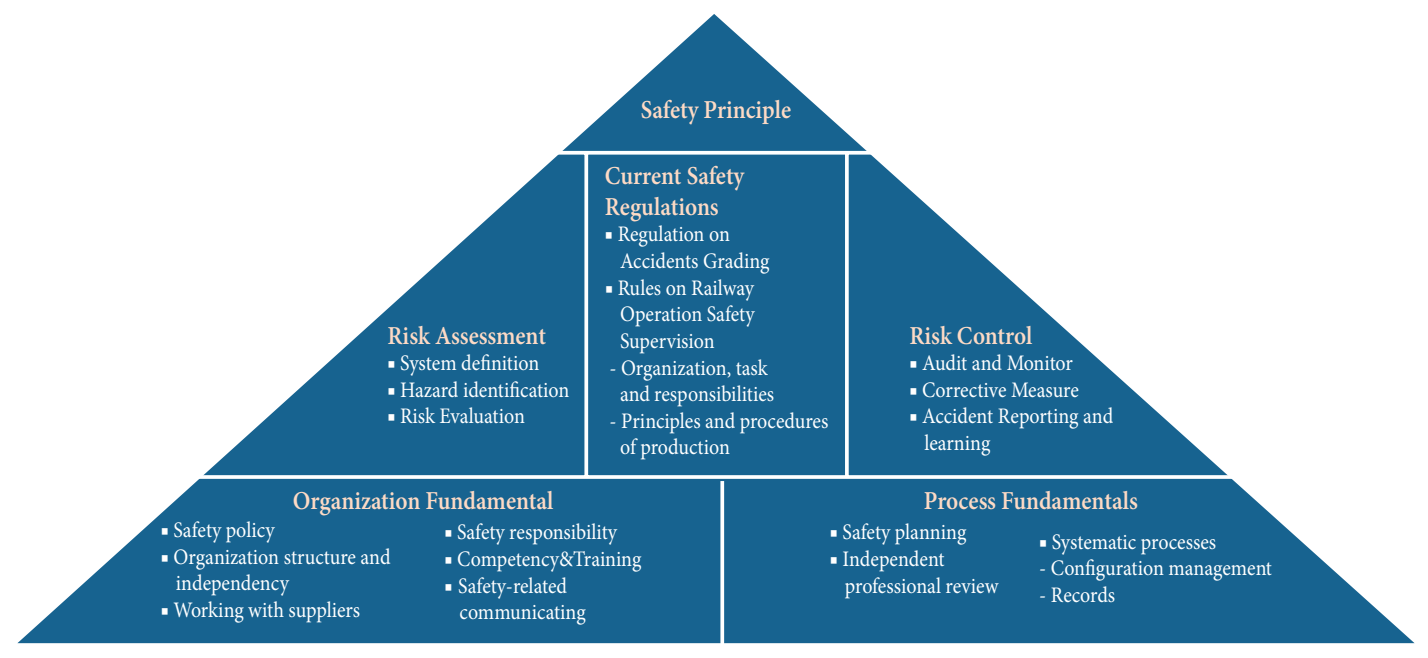

Figure 8. PDCA principle cycle (Tao Tang et al. 2009) 
Any process involved in the SMS framework should be applied to each of the life cycle phrases. It may be that specific adoption or expansion of a duty holder's overall generic SMS may be required to address specific issues relating to the various life cycle phrases.

For example, the safety policy commitments may contain specific commitments for each life cycle phase, and these should be cascaded so that the SMS framework sufficiently addresses them; however, regardless of any specific commitments the safety policy and the resulting SMS should appropriately address each of the life cycle phrases.

The quality of an SMS is typically assessed through audits, which are based on a control and monitoring loop (for example, Deming cycle). By going though such a loop, the completeness of the loop investigated can be quantified numerically, or assessed qualitatively. Therefore, if for every activity within an SMS there is a policy or a plan related to safety, evidence that it has been implemented and checked by measurement of performance is required. Also it needs to be included that the results of these checks or measurements are followed up by the management ${ }^{45}$.

\subsubsection{Indian Railways safety policy}

The Indian Railways, of their own initiative, periodically get the system reviewed and scrutinized for safety performance. During the last four decades, four safety review committees have investigated the deficiencies in the system, and have suggested reforms to improve the safety of the system.

Some of the safety policies of the Indian Railway include ${ }^{46}$ :

Measuring safety through a 'Composite Safety Index': Any system of measuring safety must meet the following two criteria: (i) validity, and (ii) reliability. Safety in any system - a railway network or otherwise - has to be an integral part of the process, methods, equipment, materials, people, etc. that it employs to produce its services. Logically speaking, measuring safety should be concerned with the quantity and quality of the system, as well as measuring events like accidents, averted accidents, other incidents, the safety performance monitoring system, human failure risk management, equipment failure, etc.

\footnotetext{
45 "Research on Safety Management System for China Railway", by Tao Tang, Chao Li and, Ru Niu, State Key Laboratory of Rail Traffic Control and Safety, Beijing Jiaotong University, China

${ }^{46}$ Measuring Safety Through A 'Composite Safety Index', Brijesh Dixit, Chief Safety Offficer, Western Railway, INDIAN RAILWAYS
} 
The safety culture/ climate as a factor while measuring safety: Assessing an organization's safety culture/ climate requires the measurement of a number of applicable contextual dimensions. The following 11 dimensions can be said to provide the main focus for ascertaining an organization's current safety culture/ climate:

1. Management commitment

2. Management actions

3. Personal commitment to safety

4. Perceived risk levels

5. The effects of the required work pace

6. Beliefs about accident causation

7. The effects of job-induced stress

8. The effectiveness of safety communications within the organization

9. The effectiveness of emergency procedures

10) Safety training

11) The status of safety people and safety committees within an organization

Corporate Safety Plan (CSP): A CSP for Indian Railways was formulated for a period of ten years (2003-2013) entailing a multi-pronged strategy, laying emphasis on prevention by reducing human dependence and mitigation of consequential effects in case of an accident. The CSP envisages a substantial reduction of accidents in IR by the year 2012-13.

Safety Information Management System (SIMS): A web-based system for overall safety management of Indian Railways has been developed in which one of the modules is related to level crossings. This level crossing management system monitors the data at level crossings by assigning a unique number to every level crossing.

\subsubsection{Railway safety bodies (government inspections) in Asian countries}

\section{China}

The Ministry of Railways (MoR) has acted as both the regulator and the operator of China's railway system ever since its establishment. The ministry is responsible for passenger services, regulation of the rail industry, and development of the rail network and rail infrastructure in mainland China. The MoR is also in charge of the operations of China Railways which manages the railway bureaus and companies in mainland China. On 10 March, 2013, it was announced that the Ministry would be dissolved and its duties taken up by the Ministry of Transport (safety and regulation), State Railways Administration (inspection) and China Railway Corporation (construction and management). 
The Chinese railway sector is governed by the 1991 Railway Law which has five main components:

1) sector administration;

2) commercial arrangements for passenger and freight transport;

3) planning, construction standards, and opening arrangements;

4) safety and protection; and

5) legal and associated matters.

The MoR is responsible for nearly all aspects of railway economic and safety regulation. But in practice, the NDRC (National Development and Reforms Commission) administers economic and safety regulation.

The structure of the Ministry includes 12 departments which cater to varied functionalities of the railways. While the department of policy and regulation formulates economic policies and industrial regulations of Chinese Railways, the development and planning department prepares long- and medium-term development plans and annual railway construction plans, and are responsible for combat-readiness, energy-saving, and environment protection of the railways. Other departments include the financial department, personnel department, department of science and technology, labor and health department, international cooperation department, and train operations bureau.

There is a separate department for safety supervision. Safety standards are enacted in the form of legal provisions. This department drafts safety laws and regulations of the railway operations and supervises their implementation. The department is also in charge of labor safety, labor protection, and the safety of boiler pressure containers, as well as the investigation and settlements of serious railway accidents.

The Public Security Bureau maintains and safeguards railways' order, and manages the safety guards of dedicated and special transport, guiding the synthesis security administration, and fire prevention. Subject to the management of Ministry of Railways and Ministry of Public Security, their duties are mainly led by the Ministry of Public Security.

\section{India}

The MoR oversees the Indian railway sector through the Indian Railway Board, referred to as MoR (IRB). The MoR (IRB) exercises all central government policy powers, and administers, supervises, and directs the entities that provide most of the rail services. The MoR (IRB) also fulfils most industry regulatory roles, except for safety oversight and railway rates appeals.

The office of the Chief Commissioner of Railway Safety (CCRS) is responsible for all safety-related aspects of IR operations and is assisted by Commissioners of Railway Safety (CRSs). To maintain independence from IR, the CCRS is under the Ministry of Civil Aviation, not the Ministry of Railways. The CRS certifies permanent way and 
rolling stock, conducts routine inspections of IR facilities and equipment, and investigates serious railway accidents. ${ }^{47}$

\section{Safety organization}

Safety organization is a coordinating service department, concerned mainly with safety audit functions, helping the relevant departments to discharge their safety functions effectively.

Safety organization was created in the Indian Railways working system based on the recommendations in reports of inquiries into serious train accidents. Initially the safety organization was functioning as one of the wings of the operating department. Based on the recommendations of the Railway Safety Review Committee, a broad-based safety department was set up with officers and staff drawn from all disciplines concerned with safety in train operations, viz., operating, engineering, mechanical, electrical, and signal and telecommunication departments manning the posts.

\section{Levels of Safety Organization}

The safety organization functions at all the three levels of organizational structure of the Indian Railways, i.e., the Railway Board at the apex level, Zonal Railways at the middle level, and Divisions at the bottom level.

At the Railway Board level, the safety directorate is headed by an adviser assisted by directors, other officers, and inspectors drawn from various disciplines. At the Zonal Railway level, the Chief Safety Officer (CSO) heads the safety department assisted by officers and supervisory staff from other departments connected with safety. At the Divisional level, the safety department is headed by senior divisional safety officers. An assistant officer is also available in some divisions. Supervisory level staff from all concerned departments is available for providing assistance at the divisional level.

The safety organization shares a common purpose in its drive towards increased reliability and availability of the rail system whilst seeking to continuously improve socially acceptable and reasonably practicable levels of safety. These are the very basic principles of sustainable development which seek to retain a holistic view and maintain risks in balance. There can never be zero risk and the safety organization's work is about helping the railways to consistently achieve a tolerable level of risk.

The broad scope and functions of the Safety Department are:

6) to sensitize all those involved with railway operations on safety-related issues;

1) to oversee all safety matters;

2) to identify safety-related susceptibilities and vulnerabilities; and

3) to enable the concerned departments to deliver.

47 Source: Railway Reform: Tool kit for improving Rail Sector Performance, Case Studies, The World Bank - http://www.ppiaf.org/sites/ppiaf.org/files/documents/toolkits/railways_toolkit/ch7_4.html 
The following activities are undertaken by the Safety Organization:

1. It audits the safety awareness/consciousness of the railway employees at all levels through normal and surprise inspections as well as super-checks. This will also include checks on availability and adequacy of rules and procedures laid down by various departments for ensuring safety in train operations and their compliance by various levels of staff.

2. It reports accidents, conducts accident inquiries, analyses the causes leading to such situations, and recommends corrective actions so as to prevent such incidents in future.

3. It monitors the disaster management mechanism of providing an effective response to untoward incidents on the railways, and also coordinates with the state government and other agencies in disaster management activities.

4. It creates awareness amongst the public for ensuring safety in railway compartments and at level crossings.

5. It creates safety awareness amongst railway staff through publication of bulletins, magazines, posters, calendars, etc., and also motivates railway staff who have acted in manner as to avoid an accident or untoward incident through cash awards and other schemes.

6. It follows up on the implementation of recommendations made by the Railway Safety Review Committee, the High level committee on Disaster management, and those by the Commissioners of Railway Safety as a result of inquiries into train accidents.

7. It monitors progress of various safety related works and activities, keeping in view the objectives and goals laid down in the Indian Railways Corporate Safety Plan 2003-2013.

\section{Japan}

The Japan Railways Group, more commonly known as the JR Group, consists of seven for-profit companies that took over most of the assets and operations of the government-owned Japanese National Railways (JNR) on April 1, 1987.

The group consists of seven operating companies and two other companies that do not provide rail services. The operating companies are organized into six passenger operators and a nationwide freight operator. Unlike some other groups of companies, the JR Group is made up of independent companies, and it does not have a group headquarters or a holding company to set the overall business policy.

Japan Freight Railway Company operates all freight service on the network previously owned by JNR. In addition, the group includes two non-operating companies. These are the Railway Technical Research Institute and Railway Information Systems Co., Ltd. 
The Ministry of Transport (MoT) is responsible for all matters relating to land, sea, and air traffic and transportation, plus maritime safety and meteorological serviceschiefly the construction and maintenance of railways, seaports, airports, and other traffic arteries and hubs that serve as social infrastructure, the construction of expressways and local traffic systems, and the review of safety and environmental considerations.

An important element in the safety of many high-speed, inter-city networks such as Japan's Shinkansen is the fact that trains only run on dedicated railway lines without level crossings. This effectively eliminates the potential for collision with automobiles, other vehicles, and pedestrians, vastly reduces the likelihood of collision with other trains, and helps ensure that services remain timely. In order to ensure the highest possible degree of safety, independent scrutiny and assessment of safety-critical products and processes is of vital importance, which the Japanese Railways has implemented successfully. Japanese railways are installing more cameras and making other improvements with their capital investment budget.

The Ministry of Land, Infrastructure and Transport (MLIT), which oversees railway companies, also focuses on security improvements for mass transportation.

\subsubsection{Harmonization of railway safety policy}

The safety policy generally reflects the philosophy and culture of safety of a country. The main influencing factor is the railway transport market, which is part of the total market of the country, including national and international sites. The main benefit of this comparison is to identify the main elements of the various railway safety policies systems in European and Asian countries and to compare them in order to analyse their compatibility and harmonization.

\subsubsection{Harmonization processing}

The main goals and means of harmonization are to:

1) increase the compatibility of railway subsystems and parts;

2) harmonize technical specifications and safety regimes;

3) increase the modal share of the railway; and

4) make railway transport more competitive.

Harmonization of the Eurasian railway corridors can only be a long-term goal because of the enormous costs involved. Innovation is not necessarily a goal of interoperability; interoperability creates conditions for an open railway market, but it does not create the market itself, neither does it solve financial problems of further introduction and improvement of interoperability. The next steps after creating this market depend largely on the political will to define and support effective migration strategies. 
Table 18. Comparison of railway safety policy systems in EU (Impact Assessment 2013)

Cultural aspects

Goals of the laws
Differences in culture, language: need for harmonization of the terminology used

- Maintaining the global railway safety in each member state and where reasonably practicable, improving it

- Harmonizing the regulatory structure

\begin{tabular}{cl}
\hline Proposition of federal rail safety laws & The European Rail Agency \\
\hline Adoption of federal rail safety laws & $\begin{array}{l}\text { The European Commission, then in each member } \\
\text { state }\end{array}$ \\
\hline Enforcement of federal rail safety laws & The member states \\
\hline Adoption of national rail safety laws & $\begin{array}{l}\text { The member states with the approval of the } \\
\text { European Commission }\end{array}$ \\
\hline Enforcement of national rail safety laws & The member states \\
\hline Structure & $\begin{array}{l}\text { Top-down bureaucracy organization by successive } \\
\text { integration process }\end{array}$ \\
& - Infrastructure managers \\
& - Railway undertakings \\
Type of company involved & Integrated railway companies
\end{tabular}

\begin{tabular}{c}
\hline Authority in rail safety for federal laws \\
Authority in rail safety for states laws \\
Accident investigation \\
\hline
\end{tabular}

EU and ERA for application

Member state's safety authority

Member state's investigating body

Safety authorization/safety certificate, including an

Type of certification SMS, established by the infrastructure manager/ railway undertaking to conform to European laws and national laws

- Applicant initiative

Submission of the demand of certification

- Railway company initiative

- On safety authority demand (on substantial change)

\begin{tabular}{cl}
\hline Approval & Member state's safety authority \\
\hline Time to take decision on certification & $\begin{array}{l}\text { Four months after the reception of all requested } \\
\text { information }\end{array}$ \\
\hline Record of "certificate" & $\begin{array}{l}\text { Member state's safety authority } \\
- \text { The European Rail Agency }\end{array}$ \\
\hline $\begin{array}{c}\text { Monitoring of company according to } \\
\text { their "certificate" }\end{array}$ & Member state's safety authority \\
\hline Validity period/revision of the & $\begin{array}{c}\text { A maximum of } 5 \text { years } \\
\text { "certificate" }\end{array}$ \\
\hline
\end{tabular}


Regarding the migration from the system of national rules to the common Eurasian "international" rules, the possibility of adopting new national rules by different countries will be limited to strictly defined cases. In this context, it is necessary to:

1. Continue the work of cataloguing and evaluating national rules

2. Identify (in consultation with relevant national authorities) which of the national rules can be removed

3. Encourage the national authorities to remove unnecessary and obsolete national rules

It is necessary to deal predominantly with the issuing of (a) authorizations for placing in the market vehicles and vehicles types, (b) authorizations for placing in service trackside control-command and signaling sub-systems, and (c) safety certificates.

The compatibility and harmonization in the EU is summarized in Table 18.

\subsubsection{National railway rules}

The railways across Europe have developed as islands over the past century with each member state choosing to adopt their own national standards (or in some cases multiple, competing, national standards) with little thought to the effects of integration across borders. These rules act as a barrier for the growth of the rail sector in terms of:

I. availability of rolling stock that can cross borders; and

II.getting vehicles and equipment authorized to operate in a number of EU member states.

National rules can be divided into National Technical Rules (NTRs) and National Safety Rules (NSRs). The agency is currently facilitating the process of notification of NTRs by the member state with the ultimate goal of removing the majority of, if not all, NTRs. However, the process is slow, with significant progress restricted only to a subset of NTRs. Given this scenario, it is difficult to obtain a clear picture of the NTRs that exist in different member states, let alone understand which ones are no longer relevant and can therefore be removed. There are also a substantial number of NSRs; there is a more advanced process in place for the notification of NSRs (relative to NTRs) and an NSR task force is currently working on further progress in this area. The number of national rules and harmonization stages are presented in Table 19, Table 20 and Table 21. 
Table 19. Total number of national rules in EU countries (Impact Assessment 2013)

Category of rules

Safety rules
Number of rules

1.200

Vehicle design technical rules-to be covered in the future by TSI (when the scope is extended)

Vehicle design technical rules-to be covered in the future by TSI (currently open points)

Vehicle design technical rules-non-TSI required for compatibility with non-TSI conform networks

$3.000(120 \times 25)$

Network design technical rules (relevant for vehicle-network interface)

Technical operational rules provided by the agency)

Technical rules for maintenance

400 (very high-level estimate provided by the agency) 
Table 20. Authorization categories used in the assessment (Impact Assessment 2013)

\begin{tabular}{|c|c|c|}
\hline Authorization Category & $\begin{array}{c}\text { Average cost } \\
\text { (in thousands } \\
\text { of } € \text { ) }\end{array}$ & $\begin{array}{c}\text { Average } \\
\text { timescale } \\
\text { (in months) }\end{array}$ \\
\hline New locomotive type authorization (the 1st country) & 6,000 & 24 \\
\hline New wagon type authorization (the 1st country) & 100 & 2 \\
\hline New multiple unit type authorization (the 1st country) & 600 & 24 \\
\hline New coach type authorization (the1st country) & 100 & 24 \\
\hline New locomotive type authorization (supplementary country) & 916 & 11 \\
\hline New wagon type authorization (supplementary country) & 0 & 0 \\
\hline New multiple unit type authorization (supplementary country) & 120 & 7 \\
\hline New coach type authorization (supplementary country) & 0 & 0 \\
\hline $\begin{array}{c}\text { Locomotive type re-authorization without ERTMS } \\
\text { (1st country) }\end{array}$ & 750 & 12 \\
\hline Locomotive type re-authorization with ERTMS (1st country) & 1,500 & 12 \\
\hline Number of wagon type re-authorizations (1st country) & 100 & 1 \\
\hline $\begin{array}{l}\text { Multiple unit type re-authorization without ERTMS } \\
\text { (1st country) }\end{array}$ & 600 & 24 \\
\hline $\begin{array}{l}\text { Multiple unit type re-authorization with ERTMS } \\
\text { (the 1st country) }\end{array}$ & 6,000 & 27 \\
\hline Coach type re-authorization (the 1st country) & 100 & 24 \\
\hline $\begin{array}{l}\text { Locomotive type re-authorization without ERTMS } \\
\text { (supplementary country) }\end{array}$ & 0 & 0 \\
\hline $\begin{array}{l}\text { Locomotive type re-authorization with ERTMS } \\
\text { (supplementary country) }\end{array}$ & 750 & 8 \\
\hline Number of wagon type re-authorizations (additional country) & 0 & 0 \\
\hline $\begin{array}{l}\text { Multiple unit type re-authorization without signaling } \\
\text { (supplementary country) }\end{array}$ & 0 & 0 \\
\hline $\begin{array}{l}\text { Multiple unit type re-authorization with ERTMS } \\
\text { (supplementary country) }\end{array}$ & 2,000 & 6 \\
\hline Coach type re-authorization (supplementary country) & 0 & 0 \\
\hline
\end{tabular}

NOTE: Zero values mean that re-authorization is not obligatory. 


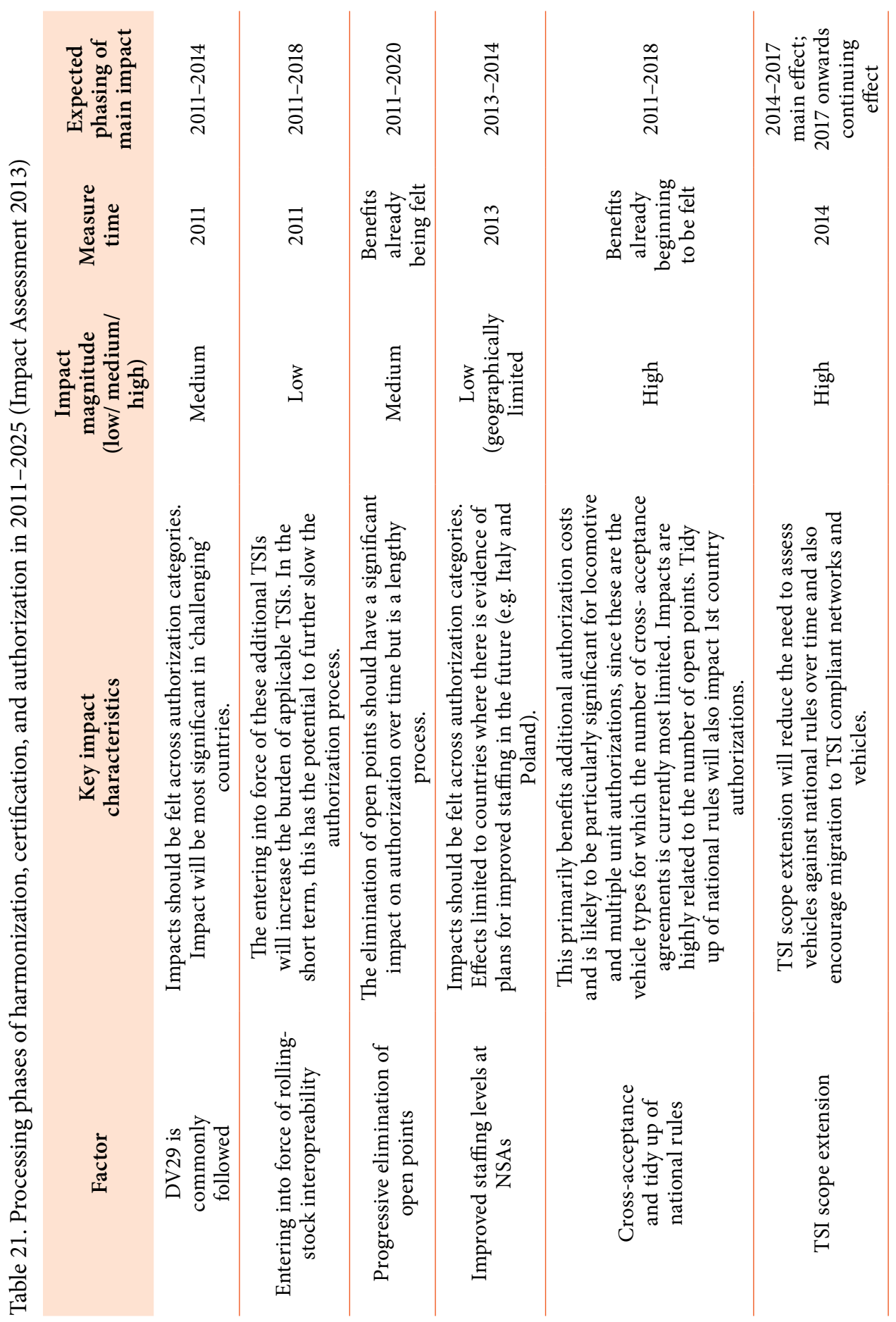




\begin{tabular}{|c|c|c|c|c|}
\hline 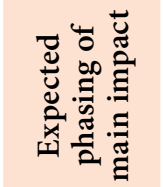 & $\begin{array}{l}\infty \\
. \\
0 \\
0 \\
0 \\
0\end{array}$ & 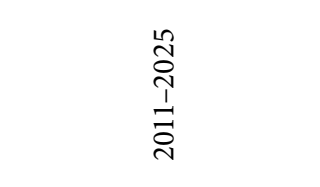 & 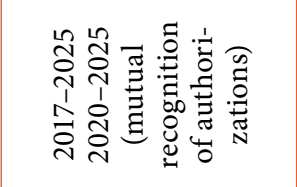 & 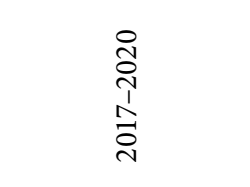 \\
\hline 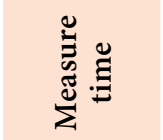 & 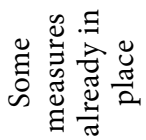 & $\overline{\vec{i}}$ & $\stackrel{\bar{c}}{\mathrm{o}}$ & $\stackrel{\widetilde{\sim}}{\vec{\nu}}$ \\
\hline 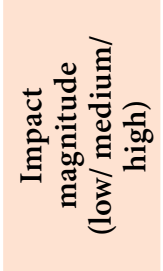 & 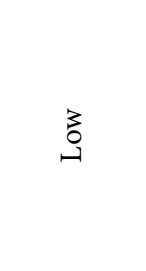 & $\underset{\Xi}{\Xi}$ & 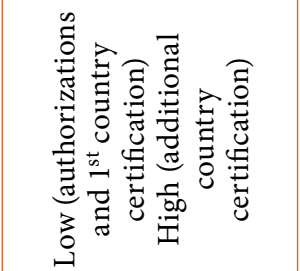 & $\underset{\Xi}{\Xi}$ \\
\hline 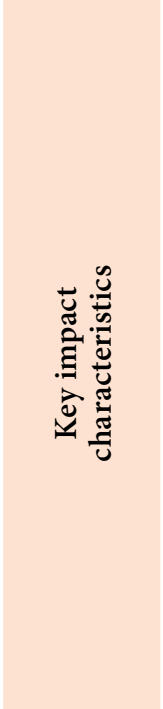 & 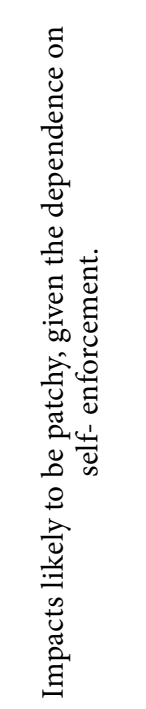 & 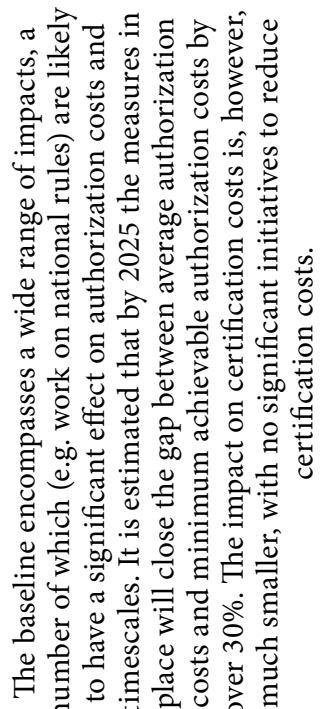 & 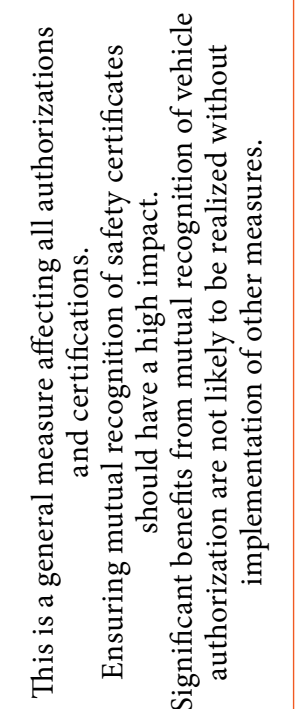 & 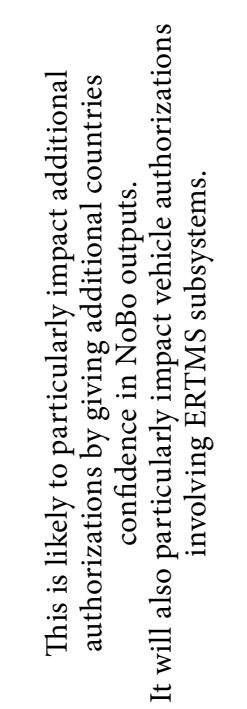 \\
\hline 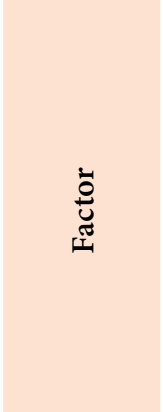 & 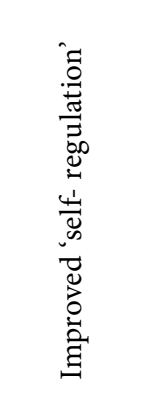 & 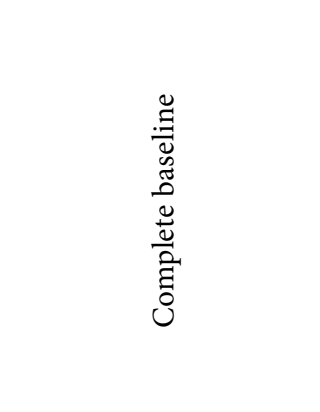 & 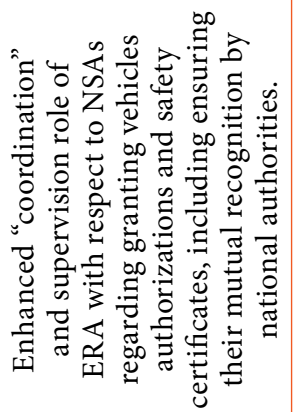 & 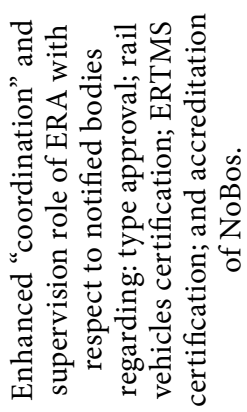 \\
\hline
\end{tabular}



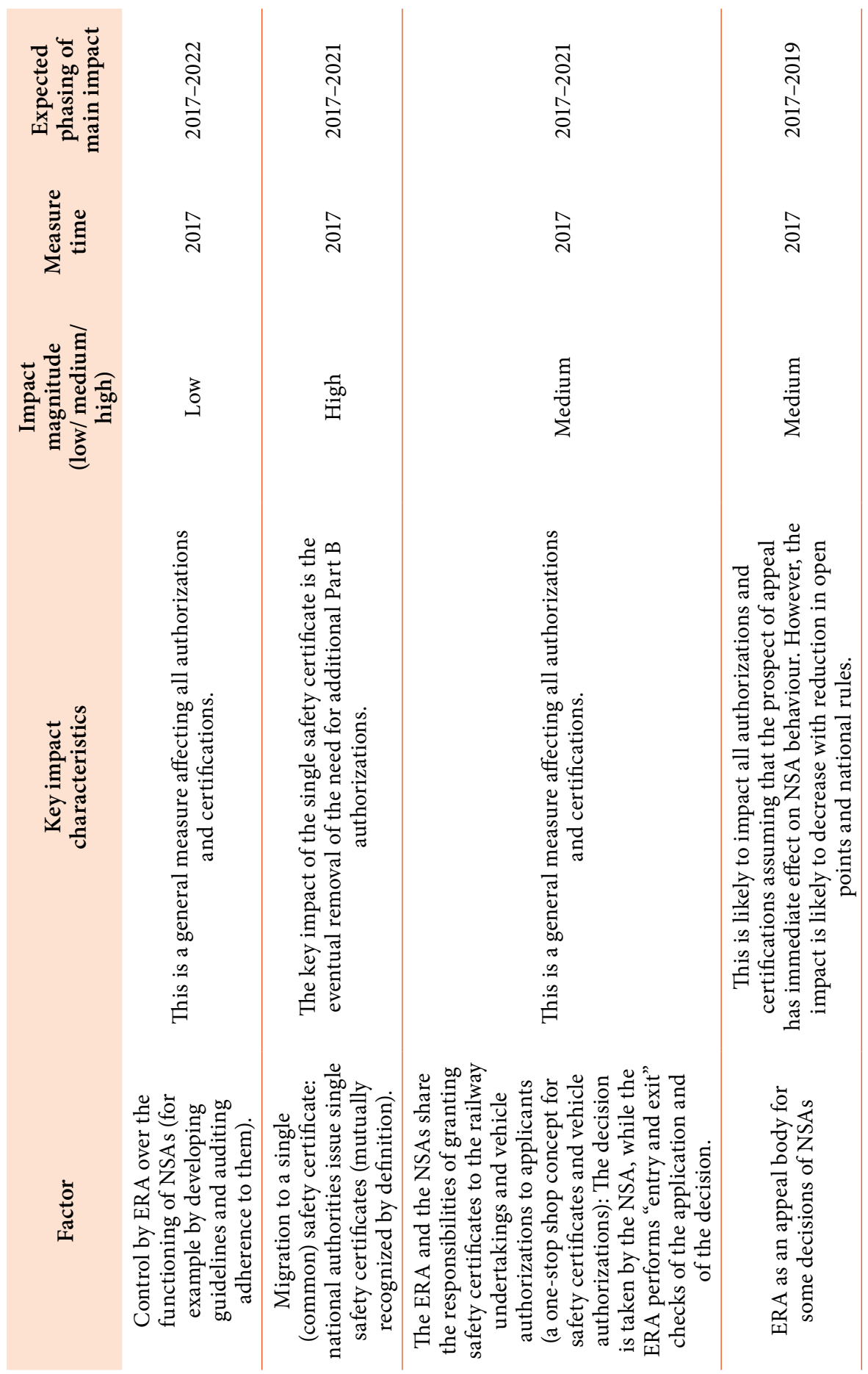


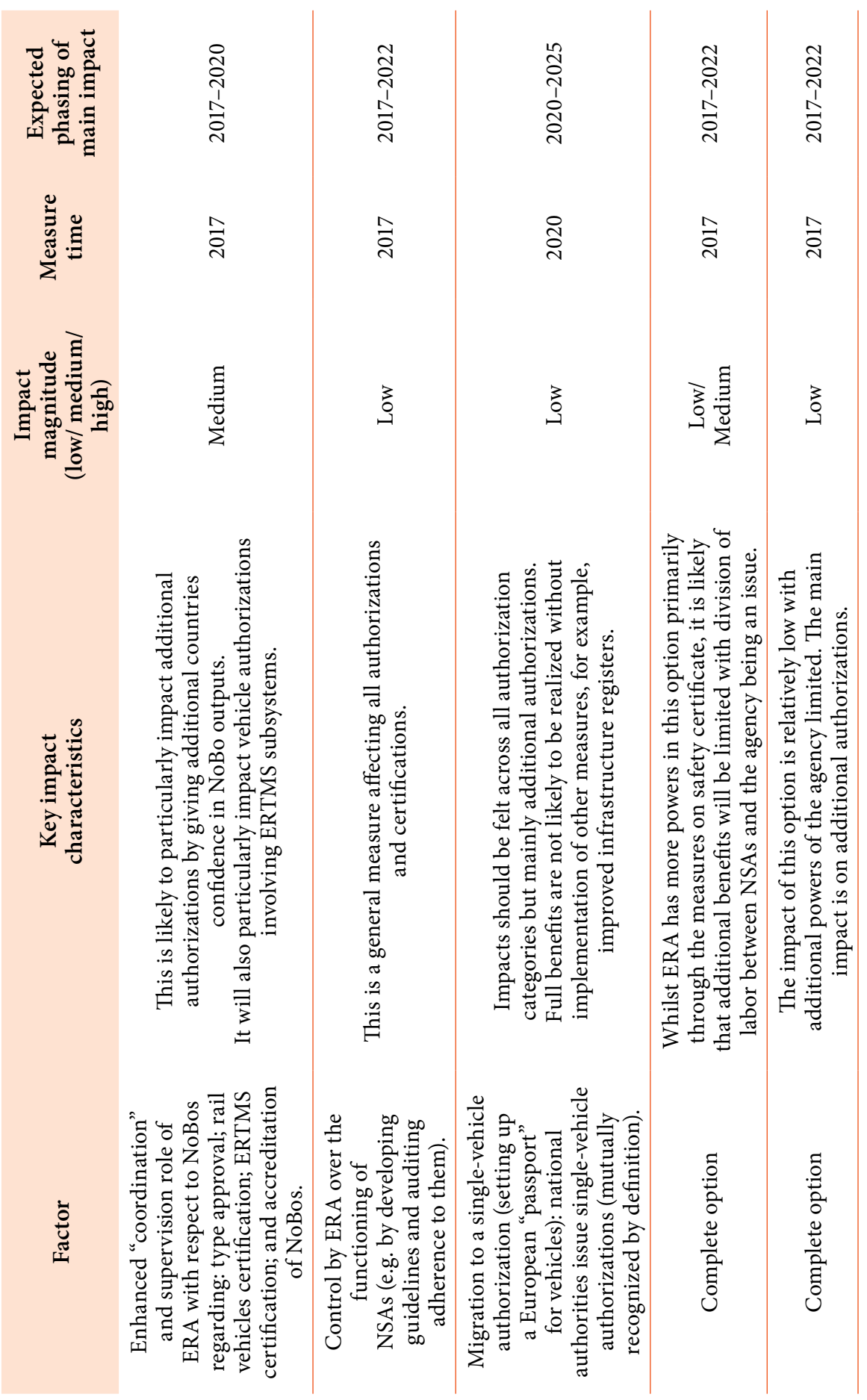




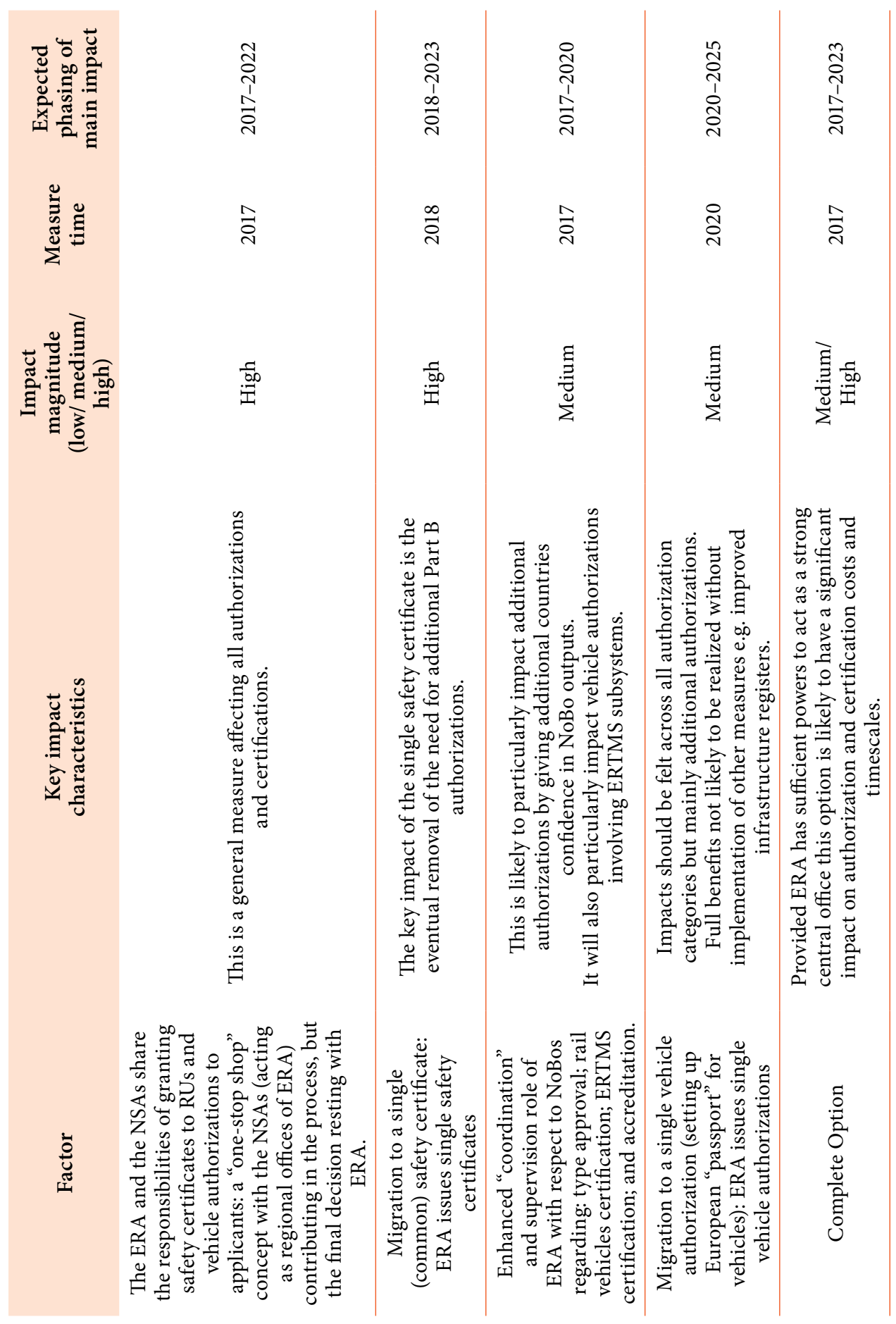




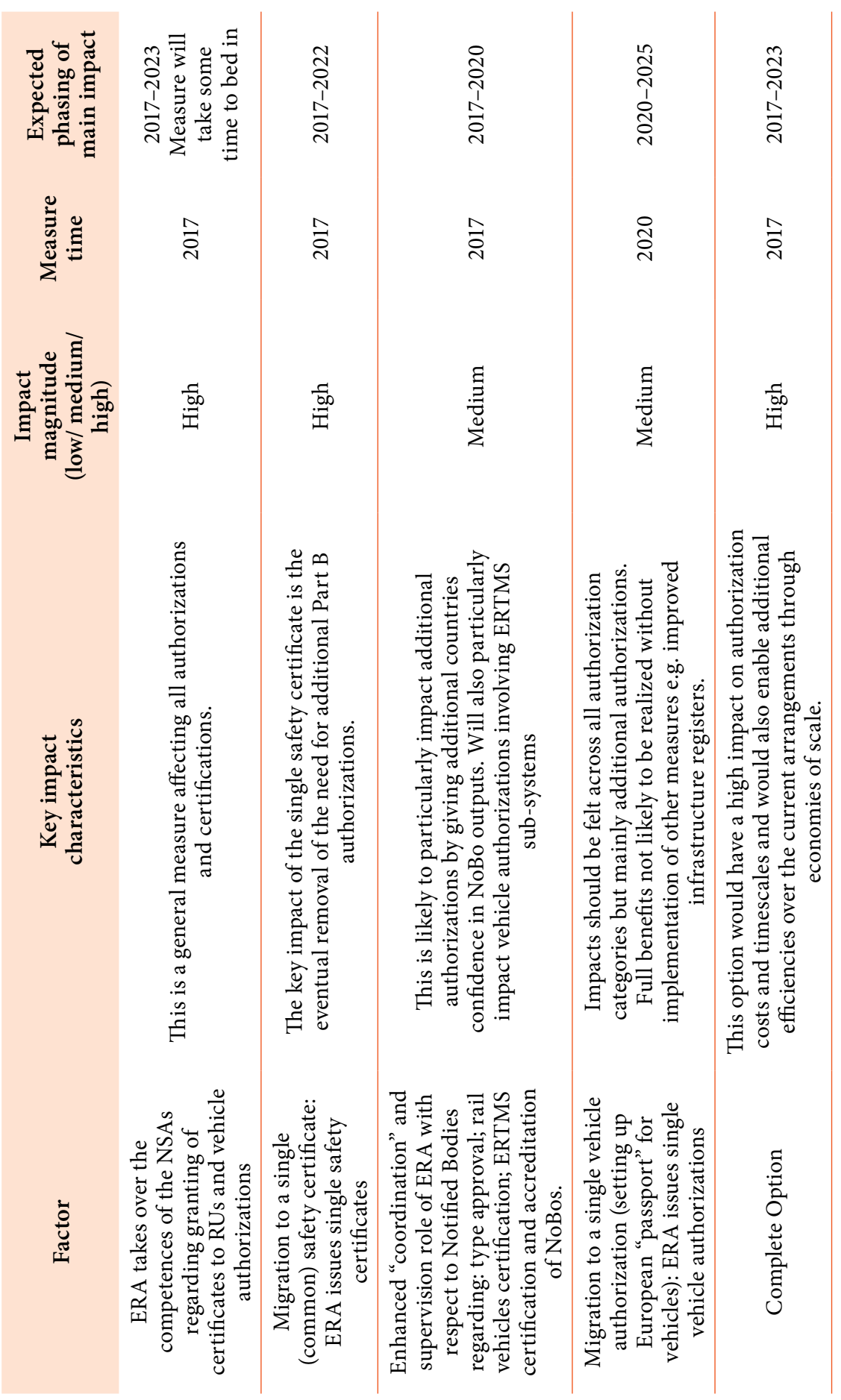




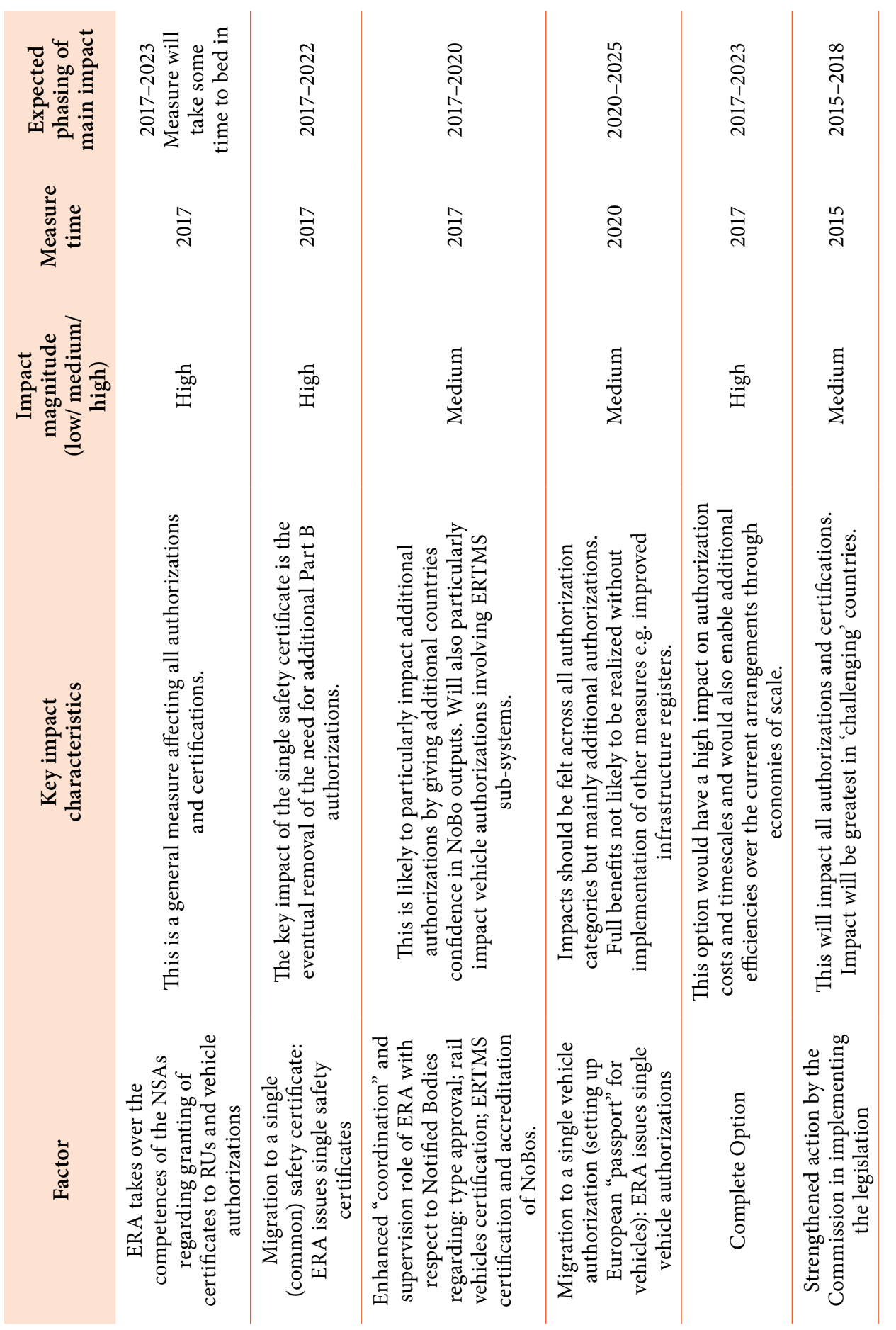




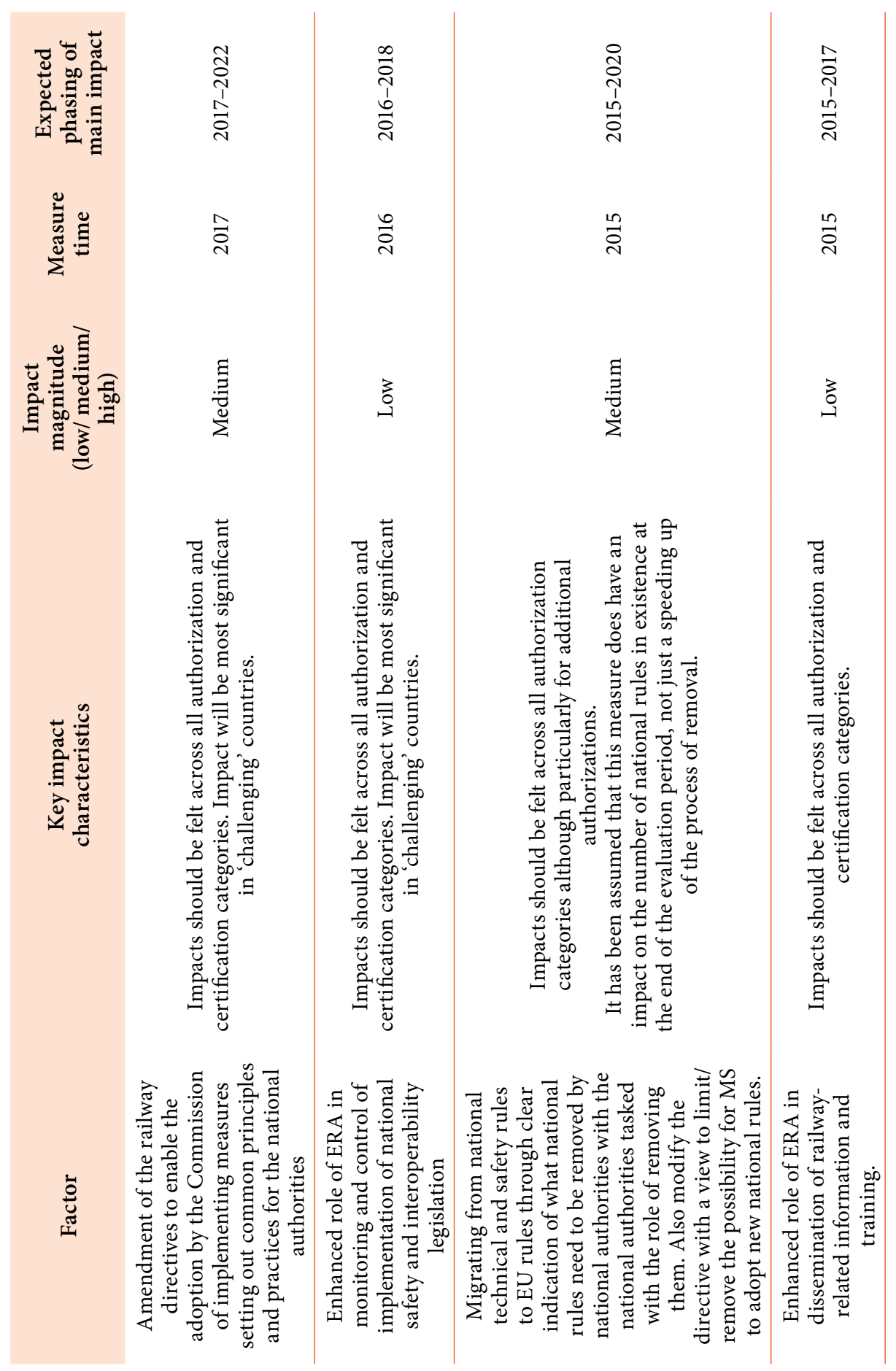




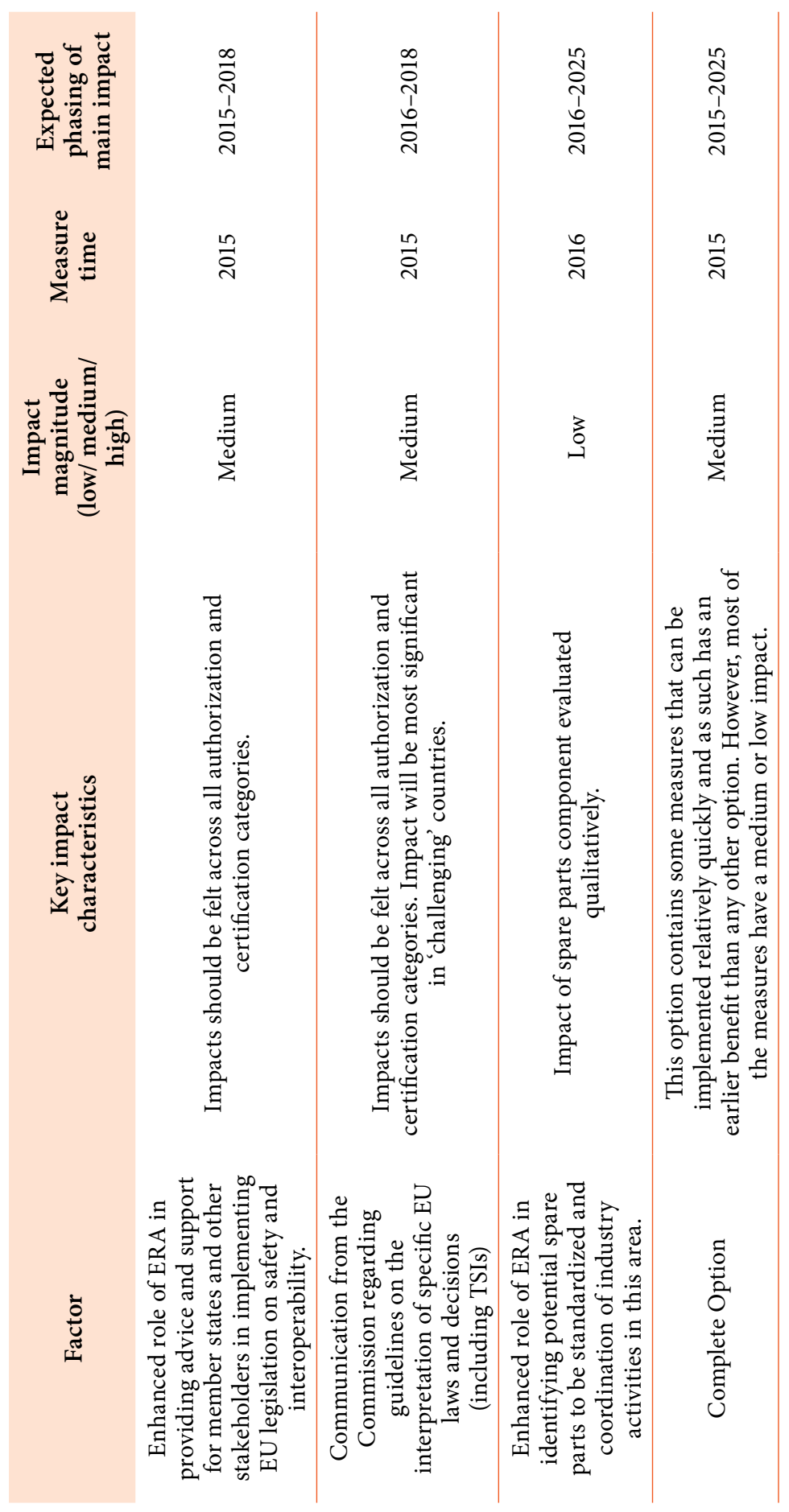




\section{SAFETY CERTIFICATION AND AUTHORISATION IN THE EURASIAN RAILWAYS}

IIIIIIIIIIIIIIIIIIIIIIIIIIIIIIIIIIIIIIIIIIIIIIIIIIIIIIIIIIIIIIIIIIIIIIIIIIIIIIIIIIIIIIIIIIIIIIIIIIIIII

Two safety certifications are mentioned in the Safety Directive. First, a safety authorization is necessary for an infrastructure manager (IM) to manage and operate rail infrastructure, and second, a safety certificate is necessary for a railway undertaking (RU) to operate on rail infrastructure. For RUs, each safety authority should give detailed guidance on how to obtain a safety certificate. It should list all requirements and make all relevant documents available to the applicant.

While an IM must obtain its safety authorization only from the safety authority in the member state where it is established, the safety certificate of a RU may cover more than one member state's rail 1network. The RU must hence apply for a "European" safety certificate in any one of the member states in which it wants to operate, and it must also apply for a "national" safety certificates from the relevant national safety authorities of each country which it wants access to.

The safety authorization/ safety certificate is renewed at the latest every five years on application by the infrastructure manager/ railway undertaking. An infrastructure manager/ railway undertaking must inform the relevant safety authorities in the event of any substantial change in their safety authorization/ safety certificate. In this case, the safety authority may request the safety authorization/ safety certificate to be revized.

\subsection{Certification problems and issues concerning the separation of railway operations from infrastructure}

\section{Certification time and cost}

The experience of some new projects already certified against TSI requirements reveals the following facts (Impact Assessment ... 2013). A great number of notified bodies 
exist in Europe; most of their work is safety assessment as an ISA (Independent Safety Assessor), and only a small part of their work is certification. It was investigated and found that a number of certificates are available, and that the certification process involves a great number of stakeholders, interfaces, products, and certificates. To manage such a process, one has to start at an early stage in the project to define all items for certification and contracts of notified bodies, and see to the integration of all issues. The separation of functions makes this hard to do.

1. Certification needs a transparent way of working, so all interfaces must be known, the requirements must be clear and the timeframe must be very strict. The separation leads to multiple interfaces and thus less transparency.

2. The parties that have to play a part in the certification process must be involved with the certification process and have to accept that other bodies have a look at their processes. This is a different way of working from how parties have worked for a long time. They have to show their way of working to other parties and be clear and transparent. This could be perceived by the employees of these companies as a threat to their company.

3. Is the process clear to everybody? Do all the participants have the same level of information? We are living in a new world and everybody has to find a new place in the process. Everybody has to find out what he thinks is the best way and has to communicate his role and boundaries to other parties.

4. Only a few people have knowledge about this way of working. In other industries (e.g. oil and gas) this way of working is more commonly seen than in the railway field. The few experts available for this work are busy with discussions in Europe for new changes to the system.

5. We can conclude that the certification process is not yet used in a stable way.

6. Co-ordination e.g. traffic control, must be formalized.

7. Some operators are more popular with the IM than others are.

8. The IM has a geographical monopoly.

9. Knowledge of the other aspects disappears; for example, the IM is not conversant anymore with rolling stock.

10. For infrastructure projects, the separation of operation and infrastructure means that the rolling stock running on a line is not known when the construction of a line starts, because it is not yet known who will operate the line. As such, and in theory, this would plead for interoperability. In practice interoperability is still insufficiently evolved to guarantee complete compliance with all requirements and complete technical compatibility. The risk exists that after the operator and its rolling stock is known, modifications to the infrastructure and/or rolling stock appear necessary. 


\subsection{Options of certification procedures}

The objective of a reduction in the average time to market (RU safety certification plus vehicle authorization timescale) is also achieved through the following options:

1) Entire corridor certificate

2) Safety certificate validation on entire corridor

3) Setting the conditions and procedures for the certification of train crews operating locomotives and trains (for example, Directive 2007/59/EC)

4) Ensuring basic rights for rail passengers (Regulation 1371/2007), for example, with regard to insurance, ticketing, and for passengers with reduced mobility

\subsection{Certificate to access railway infrastructure}

A subsystem or interoperability constituent is only really interoperable after its interoperability is demonstrated through certification. Since 1st January, 2011, the Railway Safety Directive 2004/49/EC (and subsequent amendments) required RUs to hold a safety certificate in order to be granted access to railway infrastructure. The authorities responsible for issuing these certificates are the NSAs. The safety certificate has two parts.

Part A: the acceptance of an RU's Safety Management System as described in Article No9 and Annex III of Directive 2005/49/EC. The Part A certificate is valid throughout Europe provided that the type and extent of the operation is unchanged. NSAs are therefore required to accept Part A certificates issued by other member state NSAs, should the RU request to operate on a different network within Europe.

Part B: the acceptance of provisions adopted by the RU to meet the requirements necessary for safe operation, as described in Annex IV of Directive 2004/49/EC. These cover compliance with network-specific requirements for staff competence and management of rolling stock. The Part B certificate states the ability of the RU to comply with network-specific rules applied in the member state in which the RU operates. Therefore, an RU can have a single Part A certificate but as many Part B certificates as the member states in which it provides services.

\section{Single safety certificate}

The concept of a single safety certificate for railway undertakings, already indicated as a target in the original Safety Directive of 2004, should be implemented in the following way:

1) ERA would issue all single EU safety certificates requested by the railway undertakings using the knowledge and experience of the NSAs; such a certificate will be valid in all EU member states. 
2) To this end, the railway safety directive needs to be modified in order to remove the requirement of a Part B certificate and the certification process will consist of elements described in the following section.

\subsection{Authorization of rail vehicle}

The authorizations for placing in service of vehicles (including also authorizations for types of vehicles) are issues by the NSAs. A distinction can be made between the first and additional authorizations, as well as authorizations for TSI conform vehicles and non-TSI conform vehicles. In theory, the first authorization should be valid in all member states without further checks for fully TSI-compliant vehicles running on TSIconform networks; additionally, these TSIs must be without specific cases and open points relating top technical compatibility between vehicle and the network. Therefore, in practice, additional authorizations are needed in a large majority of cases.

As a consequence, as is the case with safety certificates as well, there is great variation in both the time required and the fee charged by NSAs to issue vehicle authorizations.

\section{Single rail vehicle authorization}

The current process should be simplified and modified in such a way that there is no longer any need for an additional authorization for each member state where the vehicle is being used. The proposed new rail vehicle authorization process would be the following:

I. The first authorization is issued by ERA and consists of a "vehicle passport" which would in principle be an extract of the future ERATV (European Register of Authorized Vehicle Types), to be implemented by ERA in accordance with the Commission implementing decision $\mathrm{N}^{\circ} 2011 / 665 / \mathrm{EU}$. The vehicle passport would attest to the values of the parameters specified in the TSIs as being relevant, to check the technical compatibility between the vehicle and the network. The values themselves can be compliant with the TSIs or, in some justified cases, with the national rules. The vehicle passport may stipulate conditions for use and other restrictions.

II. The vehicle passport would no longer include the aspect of compatibility with the national network. The compatibility with any specific network is, according to the railway safety directive, already the responsibility of the RU and will be checked by the RU with the help of the future RINF (Register of Infrastructure) to be implemented by member states and ERA in accordance with the Commission implementing decision $\mathrm{N}^{\circ} 2011 / 633 / \mathrm{EU}$.

The TSIs will have to be modified in order to include not only the procedures to verify conformity with the TSI (which exist already), but also the procedure for checking 
the compatibility between the vehicle and the network and the roles of all actors involved. The results of the checks would lead to individual decisions by the RU to place a vehicle in service, and this would replace the additional authorization(s).

In order to improve the (often inefficient) functioning of national authorities, ERA would have the duty of monitoring the performance and decision making of the NSAs, including the right to audit:

1) the capacities (staffing, financial resources) of NSAs to execute tasks related with railway safety and interoperability, and

2) the effectiveness of their operations as regards monitoring of SMSs of RUs, IMs and entities in charge of maintenance.

In parallel, ERA would also play a greater role in the certification process by supervizing and coordinating the notified bodies, especially to ensure that they perform in a more harmonized way; this is of particular importance in relation to ERTMS. ERA would:

1) check that the NoBos meet the criteria provided for in annex VIII to the Interoperability Directive, and recommend any change necessary for the NoBo to retain the status conferred upon it (accreditation criteria);

2) define guidelines and templates for the assessment of conformity or suitability for use of an interoperability constituent and for the EC verification procedure (e.g. templates for the certificate, for the technical file, test report template, checklist);

3) check that application files to be submitted to the NoBo are adequately documented (including product/component test reports, on-site/in-vehicle/in-labs integration test reports) before the EC verification procedure of individual ERTMS (on-board or trackside) subsystems is launched;

4) check that the NoBos perform the EC verification procedure in a standard (high quality) manner and report as less as possible "reservations" in the certificates they deliver;

5) check that the technical files are adequately documented before the authorization of individual ERTMS subsystems are requested;

6) guide all NoBos in ERA's ad hoc ERTMS coordination group.

In addition, ERA should check that calls for tenders published in the case of individual deployment projects are in line with the ERTMS specifications (stemming from the measure, "enhanced role of ERA in providing advice and support for member states and other stakeholders in implementing legislation on safety and interoperability.") 


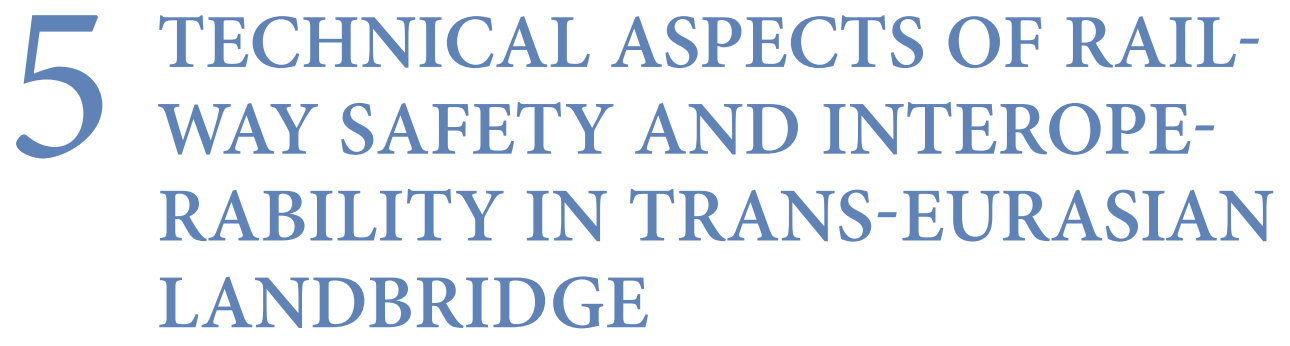

IIIIIIIIIIIIIIIIIIIIIIIIIIIIIIIIIIIIIIIIIIIIIIIIIIIIIIIIIIIIIIIIIIIIIIIIIIIIIIIIIIIIIIIIIIIIIIIIIIII

5.1. Applied global intelligent systems for rail safety and security

\subsubsection{Galileo system}

In addition to GPS and GLONASS, which were established as military systems, Galileo is the global navigation satellite system (GNSS) of Europe with focus on civil use. Presently the system is being built and full operational capability (FOC) is expected in 2016. Galileo will be the first system with guaranteed availability. Besides open service (OS), special services for commercial users are provided by commercial service (CS). It is crucial for safety critical applications to have reliable information. Galileo is planned to provide integrity information integrated in the system. This service will be called safety-of-life-service (SoL).

Considering the described features, Galileo will be a step towards applications that will use safety critical position information. The use of Galileo in train control systems, for instance, is expected to result in an augmentation of line capacity and a reduction in infrastructure costs. Like with other modes of transport, Galileo has a potential for safety critical applications in the rail sector too. Presently, applications based on GNSS can only be found in nonsafety critical areas, like passenger information systems and traffic, energy, and fleet management systems.

High requirements with regard to accuracy, availability, and reliability have to be met when using GNSS signals in the railway domain. Track selective positioning is essential for many applications. An accuracy of $2 \mathrm{~m}$ is necessary for the usual track distance of $4 \mathrm{~m}$. Position information can be augmentation systems and sensor fusion. By exploiting the characteristic of rail-bound traffic, namely, the movement in 
one dimension along the track. Together with a digital track map, fewer satellites are needed to calculate the position.

A safety critical application for Galileo in the rail sector is train control. At higher levels of the European Train Control System (ETCS), a train needs to determine its position autonomously. The combination of Galileo with an odometry platform is a reasonable alternative for existing systems, especially on regional lines. Between 2005 and 2008, the GRAIL consortium developed a strategy for the introduction of GNSS in the rail sector particularly for ETCS, funded by the Galileo Supervisory Authority (GSA). The consortium demonstrated the potential for the enhancement of the accuracy of the odometry platform as well as train integrity check.

\subsubsection{Train communication network and control}

TSI CCS (Control command safety) characteristics relevant to interoperability:

I. On-board ETCS

II. Track-side ETCS

III. European integrated railway radio enhanced network (EIRENE)

IV. ETCS and EIRENE air gap interfaces

V. On-board interfaces to Internal to Control Command

VI. Track-side interfaces to Internal to Control Command

European Train Control System (ETCS) is the signaling element of the system which includes the control of movement authorities, automatic train protection, and the interface to interlocking's. It allows the stepwise reduction of complexity for train drivers (automation of control activities). It brings track side signaling into the driver cabin. It provides information to the on-board display. It allows for permanent train control. The train driver concentrates on core tasks.

Global System for Mobiles-Railway (GSM-R) is the communication element containing both a voice communication network between driving vehicles and line controllers, and a bearer path for ETCS data. It is based on the public standard GSM with specific rail features for operation, for example, priority and preemption (eMLPP). Functional Addressing Location Dependent Addressing - Voice Broadcast Service (VBS) - Voice Group Call (VGC) - Shunting Mode - Emergency Calls - General Packet Radio Service (GPRS option) - Fast call set-up.

\subsubsection{European Integrated Railway Radio Enhanced Network (EIRENE) Specifications}

The EIRENE functional requirements specification (FRS) and system requirements specification (SRS) are released to address the complete GSM-R system requirements, 
containing in particular the requirements that are relevant to the interoperability of the rail system within the European Community, according to the Directive 2008/57/EC.

EIRENE is a railway telecommunications network based on the European Telecommunications Standards Institute (ETSI) GSM standard, which complies with all related mandatory requirements specified in the EIRENE FRS and SRS. An EIRENE network may also include optional features and these shall then be implemented as specified in the EIRENE FRS and SRS.

The EIRENE network excludes terminals:

- EIRENE Network Access Number

A number dialled as an access code to allow use of functional numbers not compliant with The international public telecommunication numbering plan [ITU-T E.164].

The EIRENE System includes terminals:

- Engine number

A number assigned to an item of traction stock on a permanent basis. The engine number may form a component of a functional number used to address users/systems of an item of traction stock.

- ETCS data only radio

The radio equipment dedicated to support the ETCS train control application data transmission requirements. This equipment includes one or several radio transceivers and their enclosure.

- Fiche

A UIC fiche or leaflet is a document adopted by UIC members. Statements within the fiche may comprise specifications which are binding on UIC members ("obligatory" specifications) or optional ("recommended" specifications). The existing track-to-train radio standard is contained in UIC fiche 751-3. It is envisaged that the EIRENE standard will be covered by a new UIC fiche, 951 .

- Functional addressing/numbering

A term used to describe the process of addressing a call using a number representing the function a user is performing rather than a number identifying the user's terminal equipment.

- Functional identity

The full alphanumeric description of the function performed by a called or calling party within the functional numbering scheme, identifying them by function or role rather than by a specific item of radio equipment or user subscription. The functional identity can include characters and numbers.

- Functional number

The full number used within the functional addressing scheme to contact an end user/system by function or role rather than by a specific item of radio equipment or user subscription. 
- General purpose radio

A standard GSM radio based closely on commercially available units for general use.

- Group call

A call made to all members of a pre-defined group within a local geographical area. Only one member of the group may talk at any instant with all other group members listening only.

- Handover

The process by which connection between the GSM mobile and the GSM network is maintained as the mobile moves from area to area, by passing communication channel control from one base station to another or between different channels in one cell.

- High priority call

High priority calls (critical group calls for drivers in the same area initiated by a driver, critical group calls for station and security staff, trackside maintenance staff and controller groups) are made in exceptional circumstances where the situation requires a higher level of priority than normal operational calls, but the same call handling regarding alerting and setup. These calls have lower priority than railway emergency calls.

- High speed line

A section of route forming part of the European High Speed Rail Network and any additional routes specified as such by national administrations.

- Link assurance signal

A form of unidirectional signaling transmitted periodically or constantly from one radio to another to allow the receiving user to detect a break in radio transmission during critical manoeuvres (e.g., during shunting).

- Location dependent addressing

A term used to describe the process of addressing a particular function (typically a controller) based on the current location of the user (typically a train).

- Maintenance settings

Maintenance settings are settings that are not normally accessible by the user in operational modes. These settings will normally be accessible only by authorized maintenance personnel.

- Multi-party call

A voice communication method whereby a number of parties defined by the call initiator may participate in the call. All parties may talk simultaneously.

- Multiple driver communications

A term used to describe communications between the drivers of each active cab in a train comprising multiple traction vehicles.

- Operational communications

These are railway communications directly concerned with train movements or train operation. For example controller-driver communications. 
The Train Communication Network (TCN) has been adopted as an international standard for use in critical transportation applications on trains. In general, TCN has excellent error detection properties and is much more thoroughly specified in this regard than other embedded network protocols. TCN is a hierarchical combination of two fieldbus systems for digital operation of trains.

The only significant recommendation for improvement is prohibiting the use of variable or multiple length frames for any particular frame ID value to guard against corruptions that can cause undetected changes in message lengths (current implementations use only single lengths, but this is not specifically required by the standard). Additionally, it is important that designers pay close attention to receiver circuitry to minimize vulnerability to ibit slipsî that could cause phase shifting and resultant burst errors in received Manchester-encoded bit streams.

\subsubsection{Relevant Research Topics, Challenges, and Obstacles}

The main goal of activity is to follow up on matters relating to the certification and validation of Galileo for railway applications in the safety area and to act in accordance with the mandate given by the UIC executive board to represent the railway viewpoint in contacts with EU projects and with the Galileo Joint Undertaking during the development stage of the Galileo project which is due to enter operational service in nonEuropean and Asia countries as well.

\subsection{Interfacing of rail vehicle devices with track-side train detection system}

\subsubsection{Overall description}

ERTMS is a train signaling and speed control system based on technical specificities that are common to all rail networks throughout Europe. It is replacing progressively the more than 20 national signaling and speed control systems currently in use, and thereby reducing the over cost of cross-border rail traffic by decreasing the risk of interoperability failures and subsequently improving safety, as well as smoothing crossborder rail operations.

ERTMS deployment policy at EU level targets high-speed and rail freight traffic. Its installation is compulsory on new high-speed lines, as well as on existing high-speed lines on which signaling systems are significantly renewed.

Eurobalise subsystem is a part of the European train control system (ETCS), which enables interoperable rail traffic all over Europe by a standardized track and train equipment (ERTMS/ETCS). 
Regarding trackside equipment for conventional lines, ERTMS deployment is compulsory on lines receiving EU co-funding. In addition, a priority network composed of six major freight corridors and areas is expected to be equipped according to fixed deadlines in 2015 or 2020. This future core ERTMS network will cover around 25,000 $\mathrm{km}$. With regard to on-board equipment, the EU set a priority on rail freight locomotives and requests that new locomotives ordered after 1 January 2012 or put into service after 1 January 2015 be equipped with ERTMS.

ERTMS outside Europe has become well established in the past years (UNIFE statistics 2012); markets in Asia have been particularly quick to take up the new technology China, Taiwan, and South Korea in particular - but a new customer base is emerging in Africa and the Middle East, Latin America, Australia, and New Zealand. As seen in Figure 9, mostly (up to 83\%) ERTMS systems are implemented in Eurasian Railways.

ERTMS is a European innovation that facilitates interoperability in cross-border operations. Customers around the world appreciate its capability to increase capacity and operate faster while guaranteeing maximum safety. It had originally been developed for the European rail network with high speed lines co-existing with a high-density freight and conventional passenger traffic network; but the system has also been proven viable for suburban rail operations as recent large-scale investments (Rio de Janeiro, Auckland, Sydney, or Mexico City) suggest.

It has been successfully implemented in European countries such as Spain, Switzerland, the Netherlands, Italy, Luxembourg, Belgium, and Poland. ERTMS has become the global standard for train control, with the European Railway Agency (ERA) acting as the system authority producing the ERTMS specifications. It is a European standard

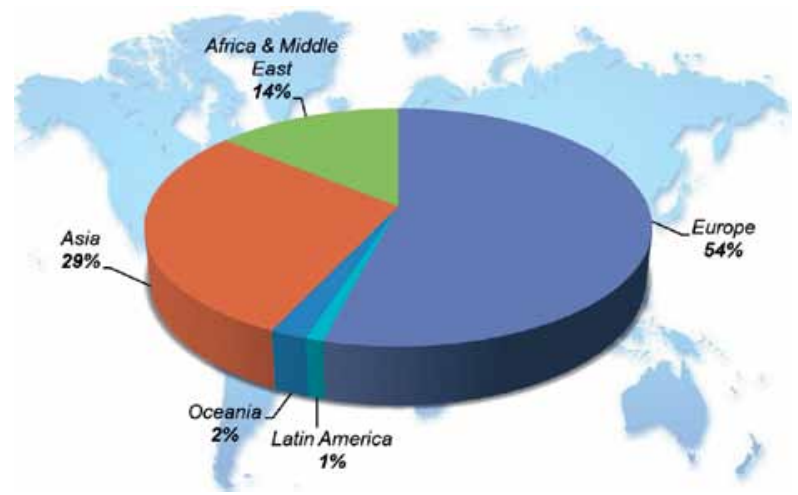

Figure 9. Trackside ERTMS contract in per cent by world-wide regions

(http://www.unife.org/uploads/120425_Press_release_UNIFE_ Statistics_on_ERTMS_Deployment.pd) 
largely used outside Europe - now with the signing of the memorandum of understanding, hopes are up that ERTMS will be uniformly implemented across Europe.

Indian Railways at present does not use any automated system for real-time online monitoring of the performance of bogies and wheel sets. Bogies are checked only during TXR examination for loose or broken parts. Wheel sets are changed when they reach the condemning limit. Problems like skew in the bogie or asymmetric wheel wear are attended to during preventive maintenance schedule only. Geometric faults in alignment and tracking of wheel are known to cause premature wear as well as abnormal stresses. Re-profiling and replacing worn wheelsets constitutes a significant portion of rolling stock maintenance costs. Misaligned wheelsets are also responsible for increased fuel consumption and accelerated track deterioration. In developed countries, state-of-theart, online monitoring systems, such as the Truck/Bogie Optical Inspection (T/BOGI) station, which measures angle of attack (AOA), and tracking position (TP) of each axle of a passing train. AOA and TP parameters combine to provide a planar description of the bogie, which is a distinct signature of a particular bogie that remains stable over time and distance travelled. Other parameters that characterize the performance of bogies are inter-axle misalignment (IAM) and tracking error (TE), etc.

\subsubsection{Relevant research issues, challenges, and obstacles}

Compatibility in terms of the type and design of rolling stock employed by neighbouring railway systems in international traffic would ensure rolling stock interoperability when no break of gauge is involved. Ideally, systems should cooperate in the design of exchangeable rolling stock to ensure that only the most efficient designs (i.e., those which maximize payload to tare ratios or minimize gross to net ratios, and are capable of running nearly at passenger speeds) are adopted.

Rolling stock compatibility issue becomes critical where track gauge continuity exists but stops being essential where there is track gauge discontinuity simply because in such situations, there can be no requirement to exchange rolling stock, but only to exchange the loading conveyed on that rolling stock.

The project manager of a collaborative European research project called SAFERAIL, Ian Nicholson, scientific research interest harmonizes with non-destructive testing methods, system integration and automating non-destructive testing (NDT) inspection.

Wheel-set fault detection is a tricky business, he says. "Usually, the only type of defect that can be picked up by a train crew is a wheel flat. A SAFERAIL priority is to develop techniques to identify faults in wheelsets before they are big enough to cause a breach of safety," says Nicholson. "There needs to be standardization of equipment capabilities for trackside inspections. This would ensure that defects are caught before manual inspection." 
Exchanges of goods between Europe and Asia are showing a steady and constant increase. These large transport volumes offer the railways the chance to carry goods between selected economic centers economically and environmentally. The opening up of new markets and the increased effectiveness of freight transport by rail require new transport technologies.

Currently, rail traffic across the different track gauges that exist in Europe (the $1435 \mathrm{~mm}$ standard gauge, the countries with a broad gauge network of 1524 or $1520 \mathrm{~mm}$ in Finland, the CIS states, and the Baltic States, and the $1668 \mathrm{~mm}$ gauge in Spain and Portugal) is heavily disadvantaged.

Matters are made even more difficult by the different coupling and braking systems to be accommodated by the traffic between standard gauge railways and the railways of the CIS, Baltic States and Belarus, Ukraine, Russia, etc. There are further differences in the strength requirements to be met by vehicles and the obstacle gauge profiles for lines and clearance of difference UIC and OSJD type wagons. These problems are not directly linked to the actual use of the gauge changeover system in East-West directions. Efficient implementation of such systems on the Eurasian routes mentioned above will only be possible, however, once these matters have been solved.

Environmental protection is to be accorded ever greater attention. It is also to be considered therefore that that some goods must not be transhipped for reasons of environmental protection (liquids), safety (dangerous goods), or passenger security.

At the interfaces between different track gauges, however, the usual solution at present is to tranship the goods to another wagon, or alternatively change the axles or complete bogie. These technologies require considerable logistical outlay, extensive trackside installations, and involve long, unnecessary stoppage times at the border.

For example, in Spain there has been a solution for passenger trains since 1969, meaning that passengers do not have to change trains and bogies do not have to be changed. It is not necessary to change the locomotives either because there are locomotives and passenger coaches in revenue service with gauge-adjustable wheel sets.

This demonstrates that a considerable reduction in transport time can be achieved at the same time as improving transport quality by using systems that can be implemented without restrictions on the railway's different track gauge networks.

An analysis of three existing systems (produced by TALGO, RAFIL, and SUW) led to the conclusion that a unification of the three changeover facilities could not be achieved without modifications to the infrastructure (the trackside installation) and the vehicles themselves (gauge-adjustable wheel sets, bogies).

The main problems with the existing gauge changeover systems for passenger and freight applications alike is that the technologies are based on privately-owned patents and are only partially compatible with one another, and there is a lack of corresponding 
rules or European and Asian standards defining uniform requirements to be met by gauge changeover systems.

It is necessary to estimate the possibility of developing a common infrastructure for three different types of gauge-adjustable wheel sets: TALGO, DB/RAFIL Type V, and PKP/SUW. Particularly the technical and economic aspects should be investigated. Two systems (DB/RAFIL and PKP/SUW) were technically compatible, but the three systems that existed at the time and their associated infrastructures were not compatible with one another. Whilst it seemed possible to develop a common infrastructure for all three systems, it would have required changes to the gauge-adjustable wheel sets and existing changeover facilities.

Currently, there is a fourth technical system for changing gauge - the BRAVA system produced by CAF. This system is used in Spain for gauge changeover operations involving locomotives and passenger vehicles.

Considering the increased traffic levels that were anticipated at the time, a trend borne out by the latest UIC statistics, an exchange of information was organized by UIC. It was concluded that the development of freight and passenger traffic between rail systems with different track gauges should be improved to offer attractive services under economically sound conditions.

\subsubsection{Objectives, subsequent applications, and assessment of benefits}

The requirements to be met by gauge changeover systems are to be defined from a technical, operational, geographical, geometrical, legal (approval of the whole Eurasian land bridge), and economic point of view. The aim is to define requirements to be met by gauge changeover systems. It will also seek to identify the interested operators, manufacturers, users, and potential applications in relation to different traffic types (passenger, freight, and combined transport).

The expected output from this exploration is a definition of the workload and costs associated with the main study, and of the economic benefits to be obtained. A business case is to be developed for the project on automatic gauge changeover systems to attract the interest of operators, manufacturers, users, and to demonstrate potential applications for different traffic types (passenger, freight, and containerized transport).

Information on traffic volumes for each type of traffic will serve as the basis for this business case. A clear indication of the necessary timeframe and budget should also be given.

For passenger traffic, investment in running gear with gauge-adjustable technology by the major European railways is not anticipated over the medium term. Only Spain and Portugal will need gauge-adjustable wheel sets in the coming years (at least 25 years) because it is anticipated that both gauges will continue to be used in revenue service over the long term for both passenger and freight traffic. 
For the south-eastern part of Europe, the completion of the standard gauge missing link between Portbou and Barcelona as well as the north-south link through the Baltic States (completion of the standard gauge project Rail Baltic from Warsaw to Tallinn) will make the need for gauge-adjustable wheel sets redundant in a few years' time. It is therefore necessary to investigate the areas which are best suited to the implementation of automatic gauge change systems.

Railway technical interoperability in Eurasian countries is essential in order to ensure the safety of and rapid response to threats for rolling stock. It shall comprise the devices with characteristics necessary for the operation of track-side train detection systems. This requires further research on issues such as these:

1. Compatibility functional and technical specifications of the track-side train detection systems

2. Communication with track-side signaling equipment (interlocking, signal.

3. Locating a specific train in a Eurobalise or other co-ordination system

4. Translating the information from track-side signaling equipment into a standard format for the control-command on-board devices

5. Formulated requirements for standard format the control-command on-board devices

6. Electromagnetic compatibility between rolling stock and control-command track-side train detection systems

7. Research and database generation for specifications rolling stock

\subsection{Reliability of wheel-rail impact measurement results by trackside control equipment}

\subsubsection{Background}

Conditions of wheelsets of running train are recorded by trackside automated control equipment (TACE), which measures parameters of wheel-rail impact and signals possible damages of wheels. Vertical forces result from wheel-rail interaction and determine all dynamic loads transferred to elements of both structures. Calculation of strength and lifetime of train running gear and roadbed of rail tracks should be based on values of these interaction forces. Railway companies using TACE face significant problems of low reliability of TACE-measured impact force values and low repeatability of TACE readings. These problems occurs because wheel-rail interaction is a completely stochastic phenomenon. Current level of technology does not allow developing reliable systems for measuring of these vertical forces during operation, and it is necessary to control the indirect indicators defining studied interaction of wheels. One of these indicators 
is irregularity of wheel running surface whose magnitude is regulated and measured in train inspection stations. Authors have evaluated derived criterion - the dynamic factor $K_{d}$, used for estimation of repeatability (reliability) of TACE readings at LG.

With the growth of rail freight and rail load, wheel-rail wear has increased. Running stability of rail vehicle and intensity of chassis wear are determined by the wheel-rail interaction. (Žygienè 2015). Wheel-rail dynamic interaction creates excess impact forces that can occur due to damages of wheel or rail, as well due to rail joints, irregularities, and switches. Parameters of wheel-rail interaction determine not only running smoothness and noise level, but also rail safety, in particular, the possibility of rail vehicle derailment. Any rail traffic interference or train delays due to car technical conditions (wheel defects) brings enormous losses to railway companies. Force of wheel impact is influenced by many factors: train speed, design of vehicle suspension (Myamlin et al. 2015), geometric parameters and stiffness of wheel running profile, wheel damage and rail irregularity, track stiffness, rail head profile and its wear, relative creepage forces caused by yawing or twisting of rail vehicle carriage, car axle load redistribution in track curves or due to transverse wind blowing, climatic conditions, etc. Wiley and Elsaleiby (2011) have identified the following factors that influence reliability of measurements by TACE: number of passages through TACE points, number of passages of loaded cars through TACE points or percentage ratio, speed of vehicle less than $80 \mathrm{~km} / \mathrm{h}$, additional passages through TACE points, carriage twisting or yawing, and replacement of wheelset.

The most frequent wheel damage that causes high rail impact forces is flat spots or wheel flats on running surface. It is known that the magnitude of rail impact force of damaged wheels is mostly influenced by vehicle speed, i.e., angular speed of the running wheel. When TACE measures impact force which exceeds critical values, the train is stopped at the nearest station and wheels of suspected wheelset are inspected to determine the true value of damage. Only then the decision of possibly continuing operation of the car is taken. Magnitude of wheel flat spots are strictly regulated, as such wheels can cause serious damage to rails and to the wheelset itself, as well as cause vehicle suspension permissible amplitudes and accelerations to exceed limits (Myamlin et al. 2015), high noise to be generated, and traffic safety to be compromised. Railway companies are interested in having reliable and simple methods to determine magnitude of wheel flat spots based on wheel impact force measured with TACE. It should be noted that at the beginning, railway automated measurement and monitoring systems started out as additional layers in the safety network, but later, they started being used to analyse wheel wear to better schedule repairs (Tuzik 2014). Track geometry data can be used to analyse rail wear and predict renewal cycles as well as simulate wheel performance. Analysis of wheel impact load detector (WILD) system application in India (Agrawal et al. 2010) showed that the system sometimes detects defects that are difficult to notice visually, and at the same time, the system sometimes does not detect 
obvious wheel defects. Determination of wheel defect root causes is important to avoid wheel redundant withdrawals in the future and to keep maintenance costs under control (Weed and Lonsdale 2004).

For the LG, the effect of TACE systems is achieved by reducing the costs of maintenance and repairs of infrastructure. To construct assessment criteria, the methodology to evaluate the economic losses from the operation of cars with defective wheels in the main railway destinations should be created. It should be noted that the introduction of such criteria will be most effective in the case of development of the database on car control results in systems for detection of irregularities on the wheelset running surfaces.

A uniform criteria for evaluation of data of system, ATLAS-LG, does not exist in Europe. Depending on local conditions, each country adds safety factors to this criterion. Comparison of the criteria used in the EU countries (Poland and Sweden), Russia, and India is shown in Table 22. Criteria are more stringent for Y-25 bogies of rigid structure and rolled wheels with S-shaped disk used in Europe. At the same time, on the roads of the EU, generally more stringent standards are observed for track and vehicle maintenance for which appropriate repair capacities are available.

Standards recommended for LG were determined based on the traffic safety of rolling stock and infrastructure as well as on the existing regulatory framework for assessment of track and vehicle technical condition and repair facilities.

Determination of dynamic processes of wheel-rail interaction is important to ensure effective use of railways. It should be noted that wheel-rail contact area of the same vehicle varies continuously due to various causes. For these reasons, efforts to create universal mathematical model that accurately describes any vehicle wheel-rail interaction in various conditions have been unsuccessful. Thus, railway companies widely use TACE systems such as ATLAS, WILD, WIM-WIM, AGUILA, etc. to monitor technical condition of vehicles during operation.

Table 22. Valid values of criteria that limit forces measured by TACE systems (similar to ATLAS-LG) for detection of defective wheels in Eurasian railways

\begin{tabular}{|c|c|c|c|c|c|}
\hline \multirow{2}{*}{$\begin{array}{l}\text { Country and } \\
\text { additional } \\
\text { information }\end{array}$} & \multirow[t]{2}{*}{$\begin{array}{l}\text { Running } \\
\text { speed, } \mathrm{km} / \mathrm{h}\end{array}$} & \multicolumn{2}{|c|}{$\begin{array}{l}\text { Criterion of maximum } \\
\text { force, } \mathrm{kN}\end{array}$} & \multicolumn{2}{|c|}{$\begin{array}{l}\text { Criterion of maximum } \\
\text { force for the speed } \\
80 \mathrm{~km} / \mathrm{h}, \mathrm{kN}\end{array}$} \\
\hline & & To repair & To uncoupling & To repair & To uncoupling \\
\hline India & $55-65$ & 200 & 350 & 260 & 410 \\
\hline Russia & N/A & 370 & 450 & 370 & 450 \\
\hline Poland (ATLAS) & N/A & 300 & 350 & 300 & 350 \\
\hline $\begin{array}{l}\text { Sweden } \\
\text { (ATLAS) }\end{array}$ & N/A & $\begin{array}{l}320 \text { (loc) } \\
190 \text { (car) }\end{array}$ & $\begin{array}{l}425 \text { (loc) } \\
320 \text { (car) }\end{array}$ & 190 & 320 \\
\hline
\end{tabular}


In 2014-15, field tests were carried out on Lithuanian railway lines for the rail vehicles with wheel damages (flats) and repeatability of TACE readings (impact force values), and the new TACE performance evaluation criteria proposed by the authors were analysed.

\subsubsection{Scientific problem of wheel-rail interaction estimation}

ATLAS-LG is a new generation diagnostic system that uses the "force" method to detect defects on vehicle wheel running surface. The idea of the force method is to move from indirect (geometrical) parameters of revealed irregularities to the identification of the really dangerous irregularities in terms of force interaction.

Obviously, in actual operation, limitation of wheel and rail defects based on type, shape, and size of irregularities is not a sufficiently reliable diagnostic method for the following reasons:

The actual shape of irregularities is different from the defined ideal shapes (flat surface or sine wave). Therefore, the presence of irregularities detected using the template often do not cause force values defined in the model. Some types of irregularities (e.g., non-uniform running) are difficult to detect in operation, but these irregularities may cause significant forces.

To solve these problems, the force method was created. Such a system would detect defects on wheels based on extreme values of forces, which present the real danger to the strength of the chassis and track. Diagnostics criteria (i.e., allowed values of forces) can be developed on the basis of the criteria obtained from the force testing facilities. These forces may affect the structural strength depending on the specific operating conditions (train speed, the type and degree of car loading, stiffness of rail base at the point of installation of TACE, etc.)

The process of the origination of vertical forces when a defective wheel passes over a rail is a stochastic process, so a single pass of a wheel with irregularity over the stretch of the measuring system does not guarantee the detection of such a defect.

Thus, the application of ATLAS does not exclude the need to control the geometrical irregularities on wheels. This is due to the fact that some combinations of irregularities, in particular, thin bandages and voids, significantly reduce the strength of wheels, especially in winter conditions. In addition, other irregularities followed by thermal processes (flats) can lead to changes in the structure of the wheel metal, and thereby weakening the wheel, which eventually results in the rejection of the wheel.

ATLAS has demonstrated a high detection reliability of dangerous wheel defects based on the criteria of track impact forces. It allows the identification of the vehicle that requires replacement of defective wheelsets and limits impermissible external 
influences on the rail tracks of Lithuanian Railways. This reduces the number of failures of rails, wheels, and other track and vehicle elements that cause derailment and accidents.

To develop the criteria for evaluating the performance of ATLAS, mathematical simulation of defective wheel-rail interaction was performed. Irregularities on the wheel running surface may be divided into two types based on the nature of their impact to a rail:

1. Irregularities causing impact force with contact loss: Flats, weld-on deposits and voids. Irregularity is determined by the depth of flats and weld-on deposits, and by the length of voids. Such irregularities are referred to as flats.

2. Isolated irregularities causing increased wheel-rail impact without contact loss (irregular rolling): Irregularity is determined by the amplitude and length. Such irregularities are referred to as irregular rolling.

Research on wheel-rail contact vertical interaction when it acquires the character of impact requires special approaches because of the high-frequency character of the studied processes due to the response generated from the damage of the running surface. Accordingly, the duration of the maximum force impact (depending on the running speed) is of the order of a millisecond or less.

\subsection{Hot axle-box/hot wheel detection systems}

Although railways rank worldwide among the safest means of transport, every year there are some serious accidents. Some of these accidents, especially in the area of freight traffic, are attributable to defective wheel bearings and brakes. If such defects develop unrecognized, they lead to the overheating of the defective bearing or of the brake, and to a breakage of the axle or of the steel tyre. A derailment of the affected wagon is the consequence. In order to identify such damage at an early stage, temperature measuring points (known as hot axle-box/hot wheel detection units, HABD/ HWD) at appropriate distances along the track are mounted on the track. These systems measure without contact the temperatures of the axle bearing boxes, wheels, and brake discs passing over them. They are used on conventional lines as well as on high-speed lines. In this way, derailments due to overheated wheels and bearings can be prevented and trouble-free rail operations can be achieved (Eisenbrand 2011). The HABD systems types and dislocation in Europe Railways is presented in Figure 10.

After assessment of the construction, reliability, and longevity of cartridge bearings, bearings of that type have been mounted on freight wagons. After starting the operation of bearings with cartridge-type axle-boxes, the heat exchange processes of which differ 


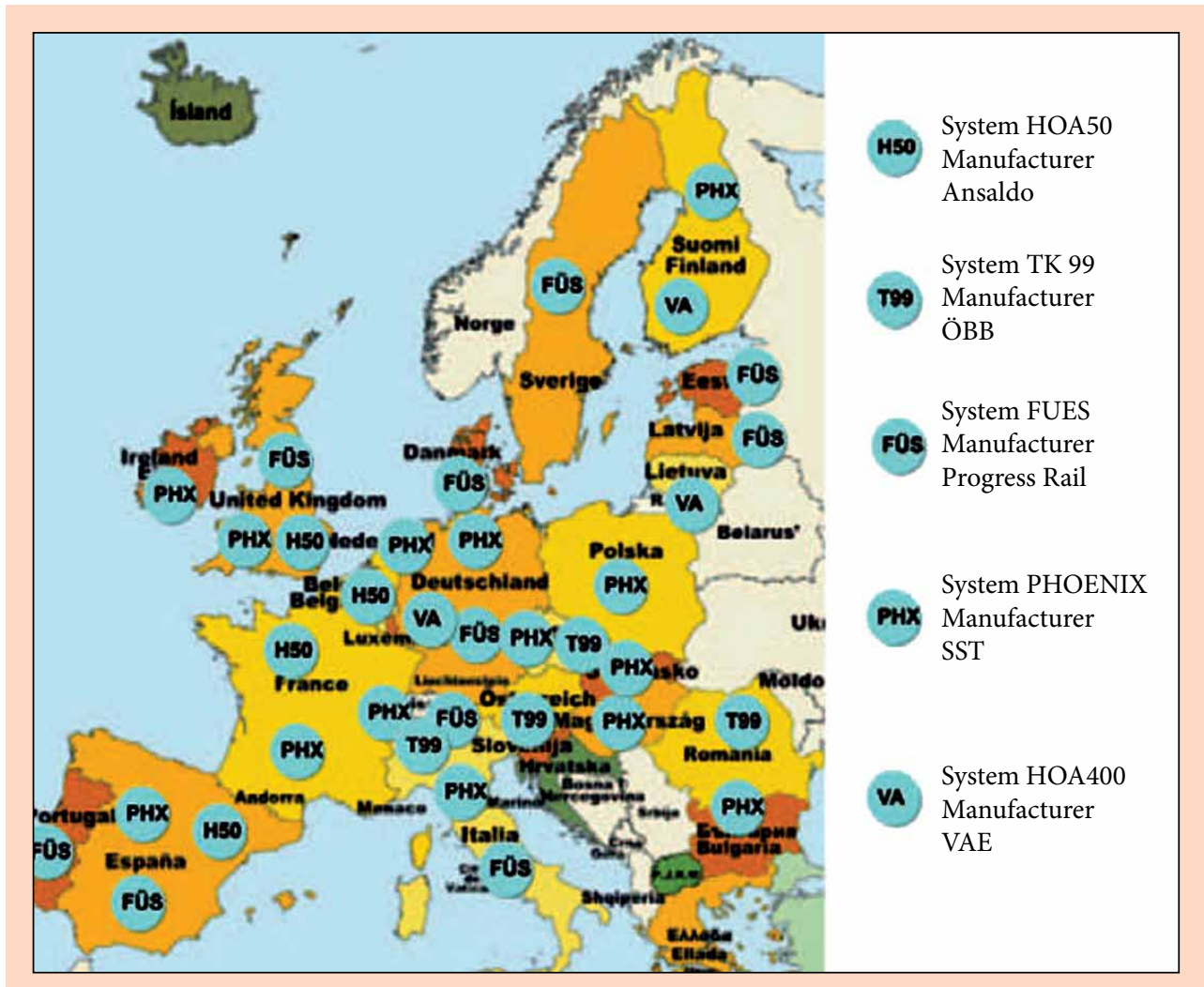

Figure 10. Hot axle-box detection systems in Europe Railways (Eisenbrand 2011)

from the heat exchange processes of standard axle-boxes, it has become necessary to remodify a hot axle-box detection algorithm of the hot rolling stock devices (HABD) so as to identify the type of the axle-boxes mounted on the rolling stock. This problem is very urgent for the operation of freight rolling stock, where a full conversion to cartridge-type axle-boxes may take time, during which axle-boxes of two types will have to be operated simultaneously.

Temperature of the axle-journal of the rolling stock axle wheel when running in a permanent regime depends on the type of bearings and their dimensions, antifrictional and hydrodynamic properties of the lubricants, gaps between the bearing rollers and rings, static and dynamic loads of the bearing, train movement speed, duration of the movement without stops, and ambient temperature. 


\subsection{Features and tendencies of rail vehicle axle-box heating}

\section{Background}

Breakdown of rolling stock axle-boxes if not detected in time may cause an accident. At present, many advanced technologies, equipment, and devices which recognize faulty axle-boxes when the train is in motion have been implemented. However, the timely identification of the breakdown of rolling stock axle-boxes is still an acute problem, the initial stage of damage emergence being especially problematic. Presently, in mostly Eurasian railways, rolling stock axle-box breakdown is determined according to the higher than permissible temperature of the axle-box body. Statistical data of dangerously heated axle-boxes, determined train delay durations, the number of delayed trains by danger level, and dependence of damage on the season are provided. After systematization of data on axle-box damage and heating temperatures of broken axle-boxes, heating tendencies of axle-boxes of freight wagons are described.

Temperature of rolling stock axle-box bodies is one of the most important parameters of diagnostics, upon exceeding thereof it is stated that the axle-box is in technical disorder (Hoeprich 1996). The normal operation of the axle-box is characterized by heat exchange balance between axle-box elements, wheelset and ambient air temperature, i.e., when the released amount of heat equals the amount of heat dissipated to the environment by the axle-box and wheelset. Axle-journal temperature when the train is running at an uninterrupted regime depends on the type and dimensions of bearings, antifrictional and hydrodynamic properties of the lubricant, spaces between the bearing rollers and rings, static and dynamical loads of the bearing, train running speed, duration of travel without stops, and ambient air temperature, and the road curves (Миронов 2008). Friction of axle-box node parts results in the heating of their surfaces. Upon reaching the limit values, this heating may cause the structural changes in the upper surfaces of the bearing parts, due to which the rollers may become clogged. Axle-journal fracture may occur after 25 minutes (or if the train is moving, on the average, at $60 \mathrm{~km} / \mathrm{h}$ after $25 \mathrm{~km}$ ) from the moment when the inner ring of the bearing spins on the axle-journal (Миронов 2009; Миронов et al. 2008; Павлюков et al. 2008). Therefore, it is especially important to locate the HABD at proper distances. The distance between two HABDs should not exceed $35 \mathrm{~km}$ (Довбня et al. 2009). With the inner bearing ring spinning on the axle-journal (one of the most dangerous axle-box breakdowns), the temperature increase variation reaches from $8{ }^{\circ} \mathrm{C} / \mathrm{min}$ to $38^{\circ} \mathrm{C} / \mathrm{min}$. Therefore, after 25 minutes (or if the train is moving, on the average, at $60 \mathrm{~km} / \mathrm{h}$ after $25 \mathrm{~km}$ ) the temperature of the axle-journal of the wheelset at the place of ring spinning may reach from $266^{\circ} \mathrm{C}$ to $800^{\circ} \mathrm{C}$. Wang et al. (1993) provide an analysis of the causes 
of axle-journal fractures of two freight wagons, whereby it was established that the temperature of the axle-journal at the moment of fracture was from $900{ }^{\circ} \mathrm{C}$ to $1000{ }^{\circ} \mathrm{C}$.

Modern HABD should ensure that axle-boxes of all impermissibly hot rolling stocks should be diagnosed. HABD danger levels are identified (Danger 1 and Danger 2), and the axle-journal heat flow temperature may be $00^{\circ} \mathrm{C}, 120^{\circ} \mathrm{C}$, or $140{ }^{\circ} \mathrm{C}$. If $\mathrm{HABD}$ is regulated when axle-journal temperature is $100{ }^{\circ} \mathrm{C}$, less is a possibility that $\mathrm{HABD}$ will not fix the impermissibly hot axle-box, whereas the number of halted trains will increase and, on the contrary, after identifying HABD danger levels according to the axle-journal temperature of $140{ }^{\circ} \mathrm{C}$, the number of halted trains will reduce considerably, and the probability of not fixing an inadmissibly heated axle-box will increase.

Axle-box breakdowns may be subdivided into four main groups: poor lubrication, fatigue, improper qualitative mounting, and contamination (with metal admixtures, water). Bearing damage occurs due to improper lubrication, excessive load, excessive rotation speed, inadequate mechanical properties, insufficient operating clearance, radial stress caused by external heat sources, obstructed run due to the breaking of the cage, and initial damage of the bearing (Gerdun et al. 2007). The damage of the boxaxle bearing mechanisms can be classified into two types: brinelling and spalling (Choe et al. 2008). Brinelling consists of one or more indentations distributed over the entire raceway circumference that is subjected to static overloading (Howard 1994). Each indentation acts as a small fatigue site, producing sharp impacts with the passage of the rolling element, eventually leading to the development of spalling at the indentation sites as the bearing continues to operate. Under normal loading conditions, the bearing will form minute cracks due to material fatigue after a certain duration of usage. With an increase in size during cyclic loading, the cracks progress to the surface and are manifested as spalling in the contact areas (Holm-Hansen and Gao 2000). Axlebox bearing defects are summarized as a wear, spun cone, corrosion, flaking, spalling, brinelling, peeling, smearing, and chipping (Harward 1994; Barden ... 2008; NNT Bearing ... 2008, The Timken Company ... 2008).

In general, bearing defects are associated with the speed of the train, wheel impact, and poor lubricant handling (Gerdun et al. 2007; Stubbe 2008). Wheel impact can result in a loose fitting bearing inner raceway. Consequently, this causes wear on the inner raceway circumference and can lead to a spun cone. In addition, wear on the race/ roller cage and solid surface can also be caused by poor lubricant handling, excessive lubrication, or lack of lubrication. It is imperative that the lubricant is clean, as it helps in prolonging the life of the bearing. A lubricant is contaminated with water may lead to a water-etched surface. Furthermore, as water is added to the bearing, rust can form inside the bearing roller or raceway. Subsequently, the wear will be magnified due to the fatigue on the contact surface between the roller and raceway, till the roller finally 
breaks. Typically, fatigue in the car body shell results from changes in the internal and external differential pressure on an airtight structural vehicle as trains pass each other in tunnels (Yagi et al. 2007).

Statistical data on the distribution of axle-box breakdowns, heating temperatures, and characteristic of these breakdowns is lacking. This research work focuses on identifying the correctness (validity) of the HABD fixed readings of hot axle-boxes, determining most frequent breakdowns of axle-boxes and their distribution, and describing axle-box heating tendencies.

\subsubsection{Examination of axle-box heating and results}

Modern methods for the calculation of rolling bearings broadly use these two: static bearing load, performed according to the residual contact stresses, and longevity according to crumbling due to metal fatigue. Other methods used have not been elaborated as they use numerous random factors that are difficult to calculate.

Breakdown of rolling stock axle-boxes may be identified in two ways: by the increased temperature of the axle-box body and by noise vibrations generated by the broken bearing. At the present time, the simplest and most reliable method for identification of rolling stock axle-box breakdowns is the measurement of the increased axle-box body temperature; it is thus used throughout the world.

Temperature change in rolling stock axle-boxes of a moving train was investigated by the temperature readings at the HABD.

HABD are mounted on the two side rails, as shown in Figure 11, to detect the heat emitted by a vibrating bearing if the inner raceway is loosely fitted or defective.

Automatic rolling stock control posts (HABD) are mainly designed to fix inadmissibly heated axle-boxes of rolling stocks, clogged axle-wheels, and wheel rolling surface defects. Axle-box heat measuring devices are installed in a special hollow sleeper and on the stopped wheels of the rail sole fastening chamber. This system aims to measure

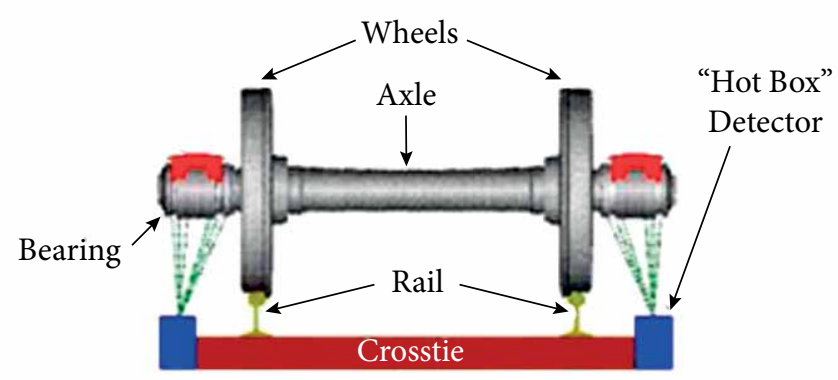

Figure 11. Principle scheme of hot box detection equipment 
absolute temperatures separately on both sides of the axle-wheel of the axle-box and axle-journal zones (left and right, according to the train running direction).

HABDs are used to calculate the following parameters according to the measured values:

1) Absolute and ambient temperature differences of axle-boxes and axle-journals (differential)

2) Absolute temperature difference of the left and right sides of axle-boxes and axle-journals, located on one axle wheel

Heating of axle-boxes is measured vertically from the bottom, and temperature of the rims of axle wheels is measured at an angle with respect of the rails. Axle-box heating systems are based on measuring infrared radiation from the surfaces under control with the axle wheel moving through the measurement zones.

Change in temperatures of wagon axle-boxes of a moving train were analysed for the entire train route. Trains were stopped at a way-station because of traffic danger. The analysis provides two categories: first-level dangers (due to the impermissibly heated axle-box, technical workers must perform a review of the relevant axle-box in more detail and determine the reason of heating, but the train may travel to the nearest station), and second-level dangers (due to the impermissibly heated axle-box, the train is stopped at once at a way-station and technical workers are called).

The results of trains halted during 2011-2013 are presented in Figure 12.

Figure 12 shows that the number of trains halted in April-July 2011 was significantly higher than in 2012-2013. After analysis, it was established that the number of trains that halted in 2011 was higher due to sunlight on the scanning device.

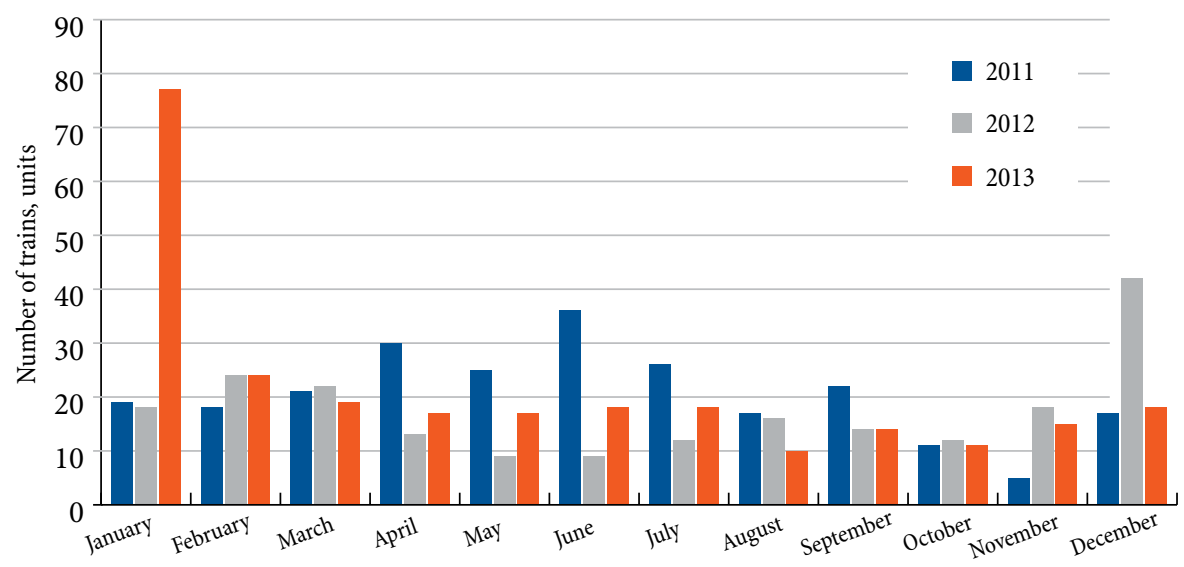

Figure 12. Dynamics of HABD halted LG trains with impermissibly hot rolling stock axle-boxes 


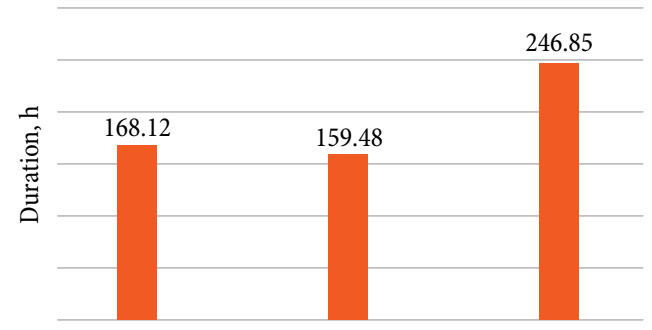

Figure 13. Dynamics of the average idle time of LG trains halted by HABD in 2011-2013
In 2011, 248 trains were halted according to HABD; in 2012, 209 trains, and in 2013, 259 trains. The number of trains halted in 2012 was highter by almost $60 \%$ as compared to 2011, and in January 2013 , by $76 \%$. This phenomenon may be explained by the fact that the railways started operating wagons with cartridge type bearings. The heat exhange processes of the said bearings differs from those of axle-boxes, where standard bearings are mounted. Seeking to avoid the ungrounded halting of the trains, HABD increased the threshold danger temperature by $5{ }^{\circ} \mathrm{C}$.

An investigation determined that HABD had fixed the increased axle-box body temperature for 123 freight trains of LG, but after a loco driver adopted a decision to drive at speed not higher than $50 \mathrm{~km} / \mathrm{h}$ (set speed $90 \mathrm{~km} / \mathrm{h}$ ), the axle-box body temperature decreased to the permissible limit. In the other HABD, the increased heating was not fixed. The total idle time of LG trains due to impermissibly heated axle-boxes fixed by HABD is given in Figure 13. Each train halting case and idle time duration were established from train handling schedules.

Figure 13 shows that the average idle time per train in 2011 was $40 \mathrm{~min}$, in 2012, $45 \mathrm{~min}$, and in 2013, $57 \mathrm{~min}$. In 2013, the average train idle time increased by $50 \%$ due to the halted trains where cartridge bearings were mounted.

The number of HABD halted trains by danger is presented in Figure 14.

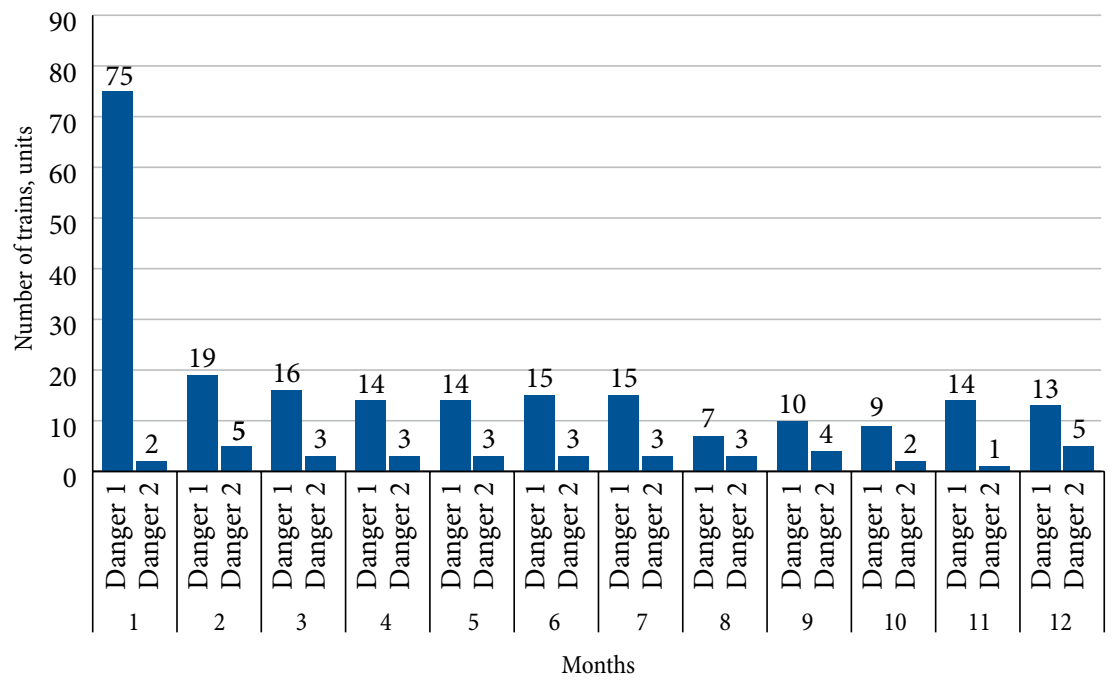

Figure 14. Dynamics of LG trains halted in 2013 by danger levels 
Figure 14 shows that the number of HABD halted trains by danger levels has almost the same tendency (except January). On an average, per month, first-level heating danger is fixed in the rolling stocks of 13 trains, and second-level heating danger in wagons of 3 trains. The least heating of axle-boxes was in August-October.

After conducting the investigation in LG, it was established that in 2011-2013, due to HABD readings, 97 freight wagons were decoupled when axle-boxes got heated impermissibly. To identify the exact reason of axle-box heating, 97 axle-boxes were dismantled. The fixed breakdown data is given in Figure 15.

Figure 15 shows that most often axle-box heating (38\%) occurred due to contamination of lubricant with water, cuts and burrs in the labyrinth part of the axle-box, and metal chips in the labyrinth part.

The following data were processed in determining temperatures according to HABD readings:

1) train passage date and time (evaluated year and day time);

2) name of the way-station where the train underwent control (distance from one HABD to another HABD);

3) train movement direction;

4) train number and serial number during the day of the specific HABD post;

5) the highest level of heating danger of axle-boxes;

6) ambient air temperature (during the train movement through the HABD post);

7) tain acceleration;

8) train weight;

9) absolute axle-box body and axle-journal temperature;

10) difference of axle-box body and axle-journal temperature (not evaluating the ambient temperature);

11) temperature differences of the left and right sides of the axle wheel of axle-boxes and axle-journals.

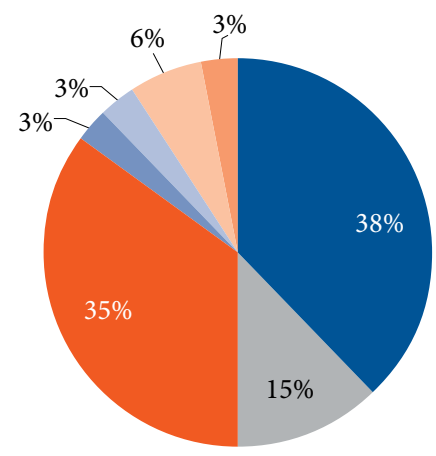

Water in the lubricant

Metal clups in the labyrinth part

Cuts and burrs in the labyrinth part of the body

Crack of the inner ring of the front bearing

Too excessive lubricant

Scratches in a herringbone pattern at the bearing roller ends

Loose fixing screws M20

Figure 15. Distribution of axle-box breakdowns of LG freight wagons 


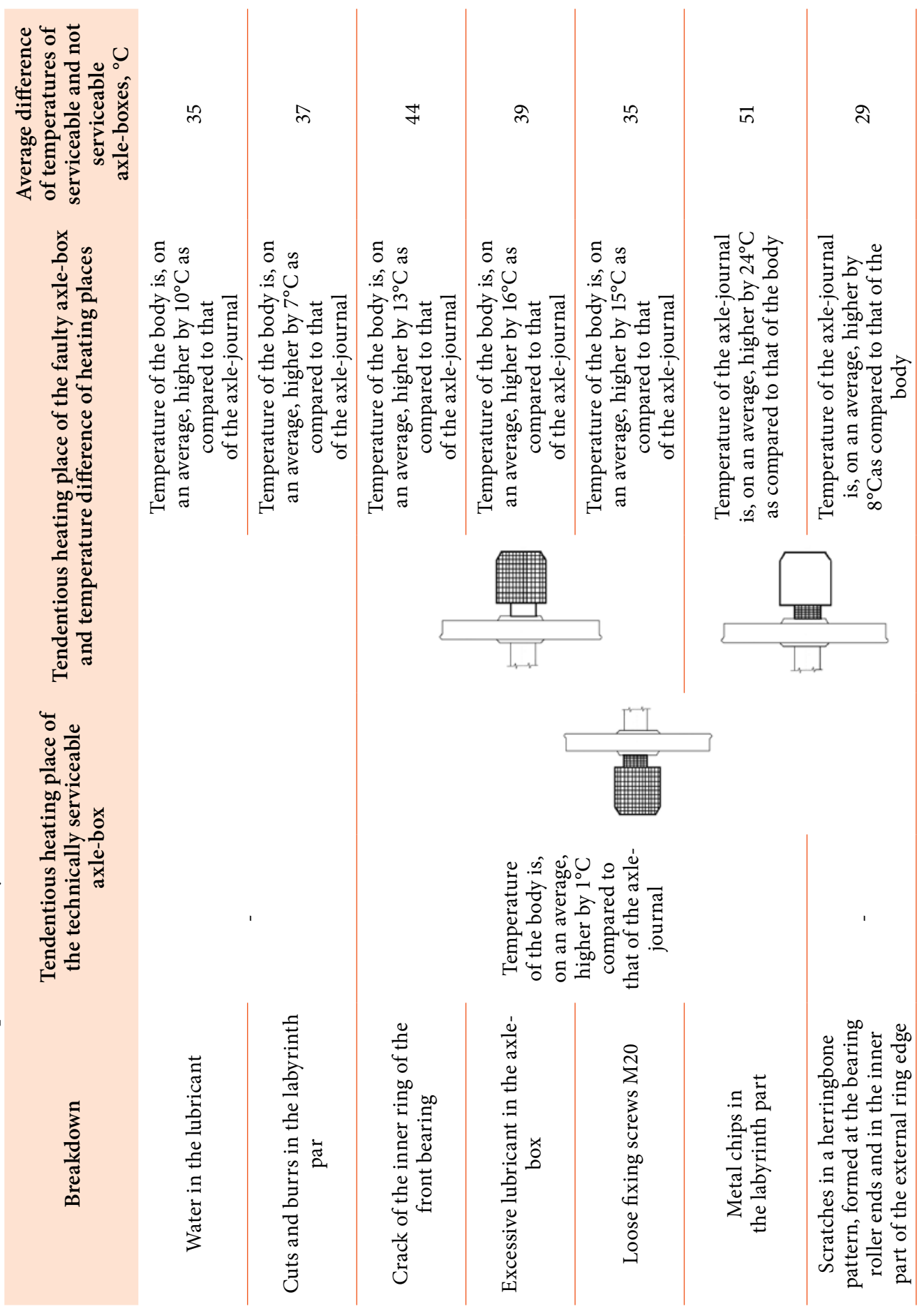


In accordance with the distribution of breakdowns and according to temperatures fixed by HABD, the temperature distribution of the axle-box body and axle-box elements is provided in Table 23.

It can be seen from Table 23 that heat exchange process of the normally operating axle-box is such that released temperature distributes evenly in an axle-box body and axle-journal. Two breakdowns of the axle-box (metal chips in the labyrinth part and scratches in a herringbone pattern formed at the bearing roller ends and in the inner part of the external ring edge) have a typical temperature increase in the area of the axle-journal. The highest heating temperature of the axle-box is monitored when there are metal chips in the labyrinth part, and the highest axle-box body temperature when there is a crack on the inner ring of the front bearing.

It would be possible to identify at the HABD not only the faulty axle-box, but also the type of the specific breakdown of the axle-box after conducting more comprehensive investigations of temperature distribution in the elements of the faulty axle-boxes and researching typical temperature increase with speeds for specific breakdowns.

\subsubsection{Conclusions}

1. Cartridge bearing heat exchange process is totally different from the heat exchange process of cylindrical bearing; therefore, it is necessary to install axle-box type recognition subsystem in HABD.

2. 2. With a train running at a speed lower than $50 \mathrm{~km} / \mathrm{h}$, the body temperature of impermissibly hot axle-box body decreases to permissible limits, and further heat exchange process is adequate to the heat exchange process of the axle-box that is in technically good order.

3. According to HABD readings, the idle time duration of halted trains of Lithuanian Railways has been increasing tendentiously; therefore, it is expedient to take measures for more precise $\mathrm{HABD}$ readings.

4. According to HABD readings, the number of halted trains of Lithuanian Railways by danger level is steady, on an average, per month: in the rolling-stocks of 13 trains, the heating danger of Level 1 is fixed, and in the wagons of 3 trains, the danger of Level 2, on an average.

5. Axle-box breakdowns of two types (metal chips in the labyrinth part and at the bearing roller ends and scratches in a herringbone pattern in the inner part of the outer ring edge) have the specific increased axle journal temperature.

6. During investigations, the authors revealed how the temperature of faulty axle-boxes is distributed in the axis and in the axle-box (Table 23).

7. The low number of axle-box heating at Lithuanian Railways was fixed in AugustOctober. 
8. It is foreseen to proceed with research and data systematization, giving an evaluation of variable train movement modes (train speed change, short stops, acceleration, etc.) and their impact on heat exchange of axle-boxes; to examine in more detail the regularities of temperature alteration of faulty axle-boxes.

\subsection{Rolling stock active safety and passive safety}

\subsubsection{Overall description}

The aim of implementation of rail vehicle active and passive systems is to considerably reduce the number of rail incidents/accidents despite increases in traffic volume. Using systematic statistical treatment of railway accidents and risk assessment including correlations of secondary collision events and corresponding levels of injury in the different body segments should help to attain the common safety targets (CST) in EuroAsian countries.

\subsubsection{Rail vehicle active safety}

Rail vehicle active safety is increasingly being used to describe systems that use an understanding of the state of the vehicle to both avoid and minimise the effects of a crash. These include train braking systems, vehicle traction control systems, and various electronic control systems that interpret signals from various sensors to help the driver control the rail traction vehicle and the train. In railway engineering, active safety systems are systems activated in response to a safety problem or abnormal event. Active safety systems may be activated by a human operator (driver), automatically by a computer driven system, or even mechanically.

\subsubsection{Locomotive signaling}

Locomotive signaling is an entire system of signaling devices along tracks and in locomotives. As the train approaches the track signals, the indications of these signals are automatically reproduced on a light signal located in the engineer's cab of the locomotive. A locomotive signaling system as an active safety system helps to avoid traffic accidents, to improve railway traffic safety, and to increase the traffic-carrying capacity of railway lines.

Locomotive signaling systems are either point control systems or continuous control systems. For point control systems, the communication between the transmitting devices along the track and the receiving devices in the locomotive exists only at certain route points. Such systems are utilized predominantly for train traffic control in sections 
that have no automatic block systems. In continuous locomotive signaling systems, the communication between track devices and locomotive devices is maintained everywhere along the route. In such systems, the transmitting track devices encode the signal indications of the track light signals. These indications are transmitted through the rail circuit to the locomotive as coded electric signals. Signals are decoded by the locomotive decoder and are converted to a display on the cab light signal corresponding to the track signal being approached by the train.

The main railway lines of the Baltic states, Belarus, Ukraine, Russia, etc. widely use the continuous locomotive signaling system combined with an automatic train stop system ("Autostop") and speed control system. The Autostop system automatically connects an electro-pneumatic valve and stops the train in the event that an engineer fails to react to the cab signal and does not push the alert lever within five to seven seconds after an interdicting signal is received. In the speed control system the driver must reduce train speed down to the speed corresponding to an indication shown on the cab light signal upon approaching an obstacle. If the driver fails to act in accordance with the stated program, the train is stopped automatically.

Future locomotive signaling systems now being developed include automatic train speed control systems combining a multi-aspect, continuous signaling system with automatic speed regulation, and a coordinate system of interval control, utilizing inductive, loop-shaped communication channels laid along tracks.

\subsection{Investigation of wheelset slip and slide control problems of locomotives with AC traction motors}

\subsubsection{Negative slip and slide process of traction rail vehicle}

When carrying heavy rolling stocks, especially when starting to move a still train or moving over steep and long slopes, locomotives face the problem of ensuring stable traction mode, that is, the phenomenon of locomotive wheelsets slip and slide. In case of driving wheel slip and slide, there is a sudden drop of locomotive traction force as well as train speed. The train may have to be stopped while going uphill, thus disturbing (or even interrupting) line track traffic.

To control and adjust slip and slide in new generation locomotives with AC traction motor drive wheelsets, it is necessary to apply different principles of electrical machine (traction motors) operation parameter tracking, measurement, and adjustment. The train driver does not need to interrupt traction mode control of the locomotive with slip and slide control system of AC traction motors, and thus, there are no conditions for the formation of the dangerous longitudinal tensile and compression forces in the 
rolling stock. This minimizes the probability of serious failure of rail vehicle. Having assessed different rail adhesion ratios and $\mathrm{AC}$ electrical machine operation peculiarities, new, dynamic slip and slide process control methods for DC/AC and AC/AC current system locomotives have been proposed. The influence of the mechanical characteristics of AC traction motors to the wheel slip process is described, and structural control schemes of the dynamic slip process are provided. The slip process formation and control conditions for wheel pairs are provided in mathematical and graphical forms. Automatic control parameters of dynamic slip and slide process for AC/AC current locomotives is provided.

The main income of railway companies comes mostly from freight transportation. Thus it is very important to ensure continuous and stable freight train traffic by transporting the biggest possible cargo amounts. For example, the most intensive freight flows of LG as well as the heaviest freight rolling stocks cross Lithuanian railways, from Belarus to the harbours of the Baltic sea, i.e., Klaipeda and Kaliningrad. The phenomena of stable driving uphill were described by Bureika (2008) and Liudvinavičius and Lingaitis (2010).

However, if sand is put under the sliding wheels, the adhesion of drive wheels with the rails increases several times and, moreover, there is a rapid increase of traction force. This force has a negative effect on rolling stocks as a huge amounts of shock force is transferred to the whole rolling stock length through automatic coupling points. This shock force affects rolling stock structures (frames, bodies, suspensions, carriages, etc.) and can harm cargo as well as their packaging. These problems were analyzed by Bąk et al. (2001) and Jastremskas et al. (2010).

There have been theoretical assumptions of locomotive wheelset slip and slide causes when carrying out research. Authors discuss theoretical and practical aspects of the formation of wheelset rolling surface conicity, rail tilt angle and wheel pair position on the track, redistribution of locomotive drive wheelset axis force to rail in traction mode in slip conditions. Peculiarities of optimum usage of adhesion weights and axis force change in traction mode are analysed. The influence of locomotive adhesion ratio change to traction characteristic and traction force change are described. Various locomotive construction schemes with AC traction motor drive are examined. Mechanical characteristics of AC traction motors are provided.

New generation diesel locomotives, for example, Siemens ER20CF, use AC motors for traction. They are significantly more reliable and simple when compared to the DC motors used earlier for drives. The three-phase asynchronous traction motor is the motor used most frequently for modern locomotive drives because of its excellent reliability, its simple, and thus, low-cost construction, and its low maintenance costs. The three-phase asynchronous traction motor is also known as squirrel-cage rotor. On 
the other hand, AC motor rotation speed adjustment differs from DC motor rotation speed adjustment. Thus, aiming to control and adjust slip and slide processes of drive wheelsets, it is necessary to apply different principles of electrical machine operation parameter tracking, measurement, and adjustment. These issues are analyzed by Lingaitis and Liudvinavičius (2006). In the following, the authors describe the causes of locomotive drive wheel slide and provide measures for the correction and control of slip and slide processes of locomotive wheelsets with AC traction motors.

\subsubsection{Theoretical presumptions for locomotive slip formation and wheelset slide}

Locomotive wheelset slippage is evident when the locomotive traction force exceeds adhesion force. The main law of locomotive traction is the following:

$$
F_{t r} \leq \Psi_{a d h} \cdot P_{a d h}
$$

where: $\Psi_{a d h}$ is locomotive wheelsets' adhesion to rail coefficient, $P_{a d h}$ is the locomotive adhesion weight, $\mathrm{N}$.

In order to maintain stable traction mode (i.e., to avoid wheel slip), it is necessary to maintain the inequality condition above. The change of locomotives wheelsets adhesion coefficient value in different seasons is provided in Figure 16.

The estimation of adhesion coefficient of a newly made locomotive is carried out by means of practical tests in different seasons and at different times of the day. In order to obtain objective results, several hundred practical tests are carried out. Figure 16 shows that adhesion coefficient values are highly dissipated as for an equal train mass, there are many factors that influence, including rain, snow, rail contamination with oil products, etc. (Vaičiūnas and Lingaitis 2010).

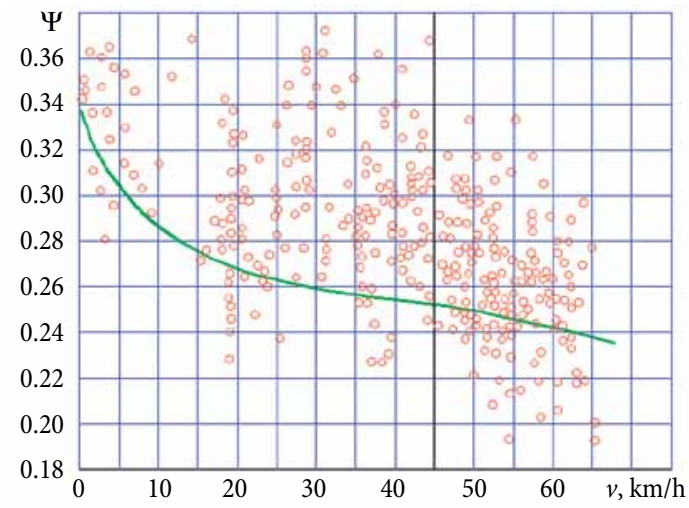

Figure 16. Locomotive adhesion coefficient dissipation dependence on locomotive speed in different seasons 
Traction characteristics of diesel-electric powered locomotive are provided in Figure 17.

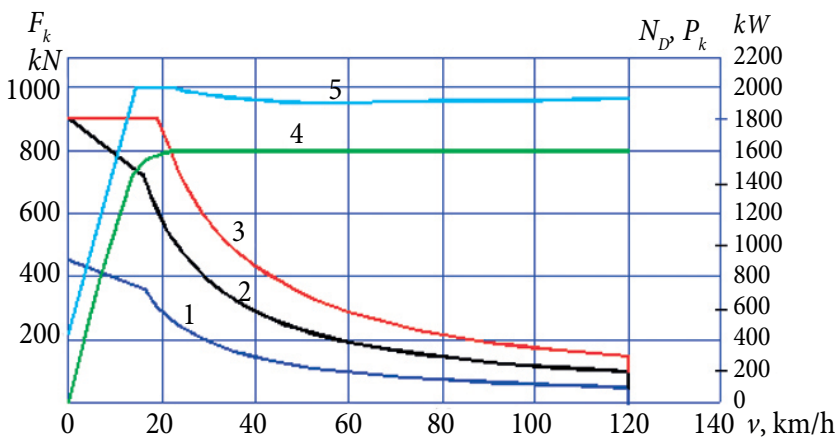

Figure 17. Diesel-electric powered locomotive characteristics in traction mode:

(1) traction characteristics of one locomotive $F_{k}=f(v)$; (2) traction characteristics of two locomotives; (3) traction characteristics of three locomotives; (4) locomotive power at wheel rim, $P_{k}=f(v)$; and (5) Diesel engine power characteristics $N_{D}=f(v)$

The diesel-electric powered locomotive adhesion coefficient value in the season change time (dissipated, e.g., 0.33 to 0.2 ) is as shown in Figure 17. However, when operating the said diesel locomotives in season change time, the rolling stock mass is not adjusted due to the changes of adhesion conditions. Caused by the decrease of the adhesion coefficient, the traction power becomes insufficient for towing of this rolling stock. In such a case, sand is sprinkled intensively to increase the adhesion coefficient. However, locomotive starting traction time is increased due to intensive slipping, thus causing accelerated wheelset and rail wear.

\subsubsection{Slipping process of locomotive drive wheelsets: Peculiarities of locomotive traction and train movement resistance force operation}

The wheel-to-rail force redistribution scheme (in traction mode) of locomotive drive wheelset axle is provided in Figure 18. The scheme illustrates the "rising" moments $M_{\mathrm{o}}$ that emerge in traction mode that decrease the wheelset force to the rail of the first wheelset by one value $\Delta P$ (rise up) and increase the axle load to the rail of the second wheelset $\Delta P$ (press down). Such torques are formed due to the traction force $F_{\text {tr }}$ of locomotive drive wheelsets that acts as a wheelset tangent and the moment of train resistance force $W_{j}$ that acts at the height of the automatic coupling point $h$.

Locomotive traction force at wheel rim and the locomotive movement resistance force at the automatic coupling point $h$ form the force pair for the "rise" torque $M_{0}$ that decreases the load of locomotive front wheelset and increases the final wheelset to rail force. Thus, the least loaded wheelset is the first to lose the necessary adhesion with the rails. The most frequent slip occurs at the first wheelset. Locomotive traction force is 


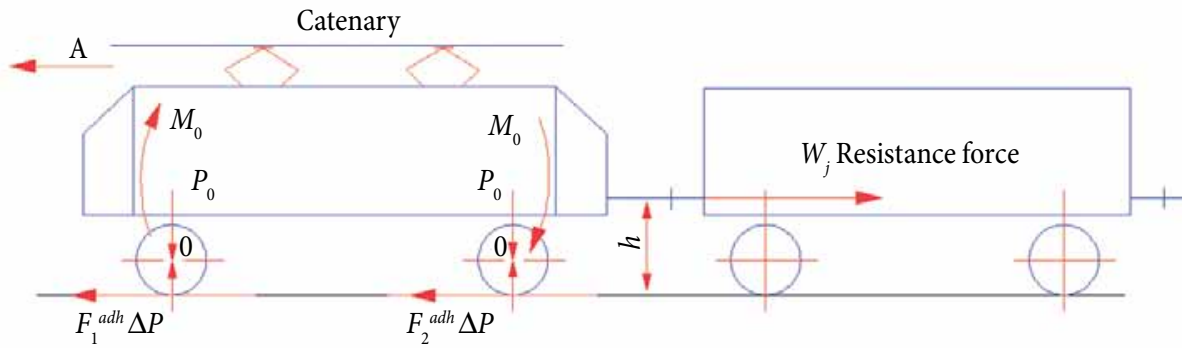

Figure 18. Wheel to rail force redistribution scheme (in traction mode) of locomotive drive wheelset axle: $F_{1}{ }^{a d h}$ and $F_{2}{ }^{a d h}$, drive wheel traction forces; $P_{o}$, wheel-to-rail force; $W_{F}$, resistance force at automatic coupling point; $h$, height from the railhead to automatic coupling point.

also influenced by wheelset traction force unevenness. If less loaded wheelset produces bigger traction force, it starts slipping earlier (when the traction force it produces is smaller), and this decreases the total locomotive traction force.

\subsubsection{Peculiarities of engine operation and location of wheelset to rail static force}

Traction engine operation and the influence of its location to static wheel-to-rail force are especially significant when the suspension of traction motor is axial-supporting. Active forces and torques of the said situation are provided in Figure 19. Traction motor achieves torque $M_{\mathrm{p}}$ that rotates the wheelset. Traction motor shaft is connected to the wheelset via a reducer. If the traction motor is located at the wheelset as shown in Figure 19 and the locomotive moves in the defined direction, force $P_{3}$ is directed upward.

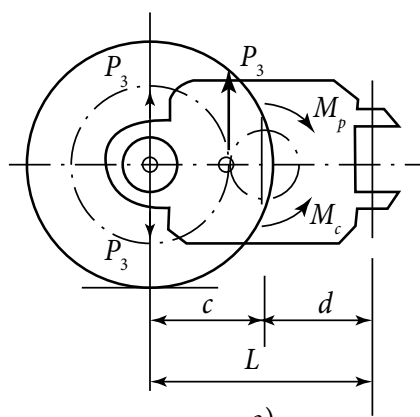

a)

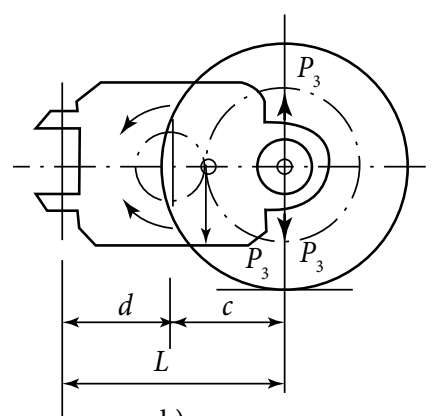

b)

Figure 19. Different schemes of electric traction motor dislocation influence on the wheel-force-to rail: $P_{3}$, electric traction motor force to rail; $M_{p}$, motor torque applied to the motor shaft; $M_{\mathcal{c}}$, resistance torque applied to traction motor shaft. 
Moreover, motor stator is influenced by torque $M_{s}=M_{v}$ that is applied to the motor supports by the force $P_{3}$, calculated as follows:

$$
P_{3}=\frac{M}{L} ;
$$

Thus by locating the traction motor behind a wheelset and with a supporting-frame suspension of the traction motor, the wheel-to-rail force is decreased by the value $\Delta P_{i}$.

When the locomotive changes its movement direction, the wheel-to-rail force increases by the same value.

\subsubsection{Peculiarities of locomotive axle force change in traction mode}

The bogie-to-rail force redistribution scheme (in traction mode) of the six-axle locomotive is provided in Figure 20. Frames of bogies are affected by drive wheelset traction forces $F_{a 1}, \ldots, F_{a 6}$ and the automatic coupling point of rolling stock is affected by movement resistance forces $W_{\mathrm{j}}$ that are equal, $W_{j}=n \cdot F_{a s}$. Due to the operation height difference of the traction force $F_{T}$ generated by locomotive drive wheelsets and train movement resistance force $W_{j}$ that acts at coupling point, there is torque $M_{T}$ :

$$
M_{T}=n \cdot F_{a} \cdot\left(h-r_{r}\right) ;
$$

where: $n$ is the wheelset number, $F_{\mathrm{a}}$ is the traction force of one drive wheelset in $\mathrm{N} ; h$ is the coupling point height (distance from railhead to the coupling point longitudinal axis) in $\mathrm{m} ; r_{r}$ is the wheelset rolling radius in $\mathrm{m}$.

$F_{a 1}, F_{a 2}, F_{a 3}, F_{a 4}, F_{a 5}, F_{a 6}$ are the traction forces of drive wheelsets; $W_{j}$ is the movement resistance forces that act on the rolling stock; $q_{a}$ is the static wheel-to-rail force of a wheelset; $h$ is the height from the railhead to automatic coupling point; $B$ is the distance between bogie centers (basis); and $A$ is the locomotive's movement direction

Catenary

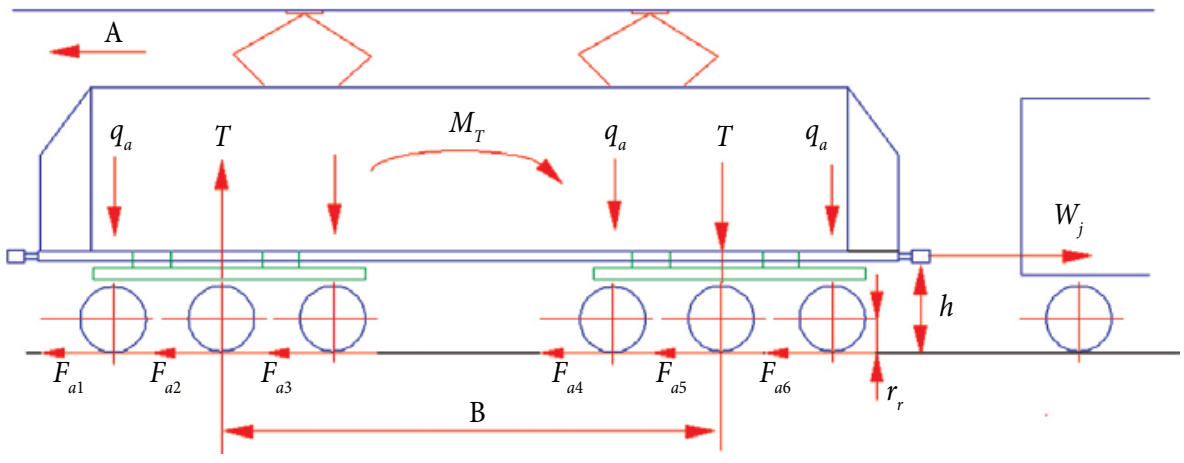

Figure 20. Redistribution scheme of locomotive bogie to rail force: 
Torque $M_{T}$ tilts the locomotive body along the axis $\mathrm{Y}$ that crosses the locomotive weight center $\mathrm{C}$ and changes the value of vertical force $T$ acting on bogies. It is calculated as follows:

$$
T=\frac{M_{T}}{b} ;
$$

where: $b$ is the distance between bogies (basis) in $\mathrm{m}$.

Wheel set force change $\Delta P_{\mathrm{i}}$ is calculated as follows:

$$
\Delta P_{i}=\left|R_{T}\right|=\frac{T}{m}=\frac{M_{T}}{m \cdot b} ;
$$

where: $m$ is the bogie wheelset number.

At torque $M_{T}$, the first bogie is less loaded and the second one is more loaded.

\subsubsection{Peculiarities of locomotive adhesion coefficient changes}

Locomotive traction force is influenced by inequalities of traction forces of every wheelset that are formed due to the uneven distribution of the locomotive weight between wheelsets. If less loaded locomotive wheelset produces too high traction force compared to the adhesion conditions, slipping starts at a lower traction force, thus lowering the total locomotive traction force. Adhesion coefficient is also influenced by rim erosion, rail wear, and differences in wheel diameters of wheelsets. At road curves of small radius, wheelset adhesion to rail is worse due to wheelset slide caused by uneven distance that is travelled by a wheel of the wheelset. Adhesion coefficient depends on the locomotive electric drive type (AC/DC or $\mathrm{AC} / \mathrm{AC})$, traction motor connection type, and traction motor's mechanical characteristics. The locomotive traction force may decrease by the force due to wheelset force to rail redistribution and is calculated as follows: $\Delta P=\Delta P_{1}+\Delta P_{2}$. Force of the least loaded wheelset is calculated as follows:

$$
2 P_{\min }=q_{a} \cdot(1-0.03)-\Delta P ;
$$

where: 0.03 is the tolerance of the static force to rail of wheelset according to technical locomotive characteristics with load $q_{a}$ less than $225 \mathrm{kN}$.

Ratio of the least loaded wheelset and calculable force is called locomotive adhesion use coefficient $\beta_{k}$ and is expressed as follows:

$$
\beta_{K}=\frac{q_{a \min }}{q_{a}}=\frac{q_{a}\left(r_{r}-0,03\right)-\Delta P}{q_{a}}=0,97-\frac{\Delta P}{q_{a}} .
$$

Locomotive adhesion use coefficient shows the part of the traction force that is actually achieved by the locomotive. Having analyzed the said theoretical presumptions, it can be said that locomotive adhesion use coefficient depends on wheelset and traction motor location, suspension type, traction motor's mechanical characteristics. 


\subsubsection{Locomotive DC and AC traction motor speed-torque characteristics}

Locomotive traction motor mechanical characteristics are in Figure 21. Speed-torque characteristics of the DC and AC traction motor are described by Fuest and Döring (2007). The speed-torque natural characteristics are different (Strekopytov et al. 2003).

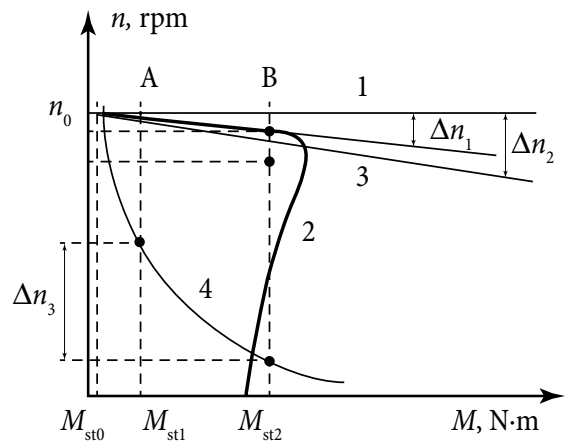

Figure 21. Speed-torque characteristics of the DC and AC traction motor:

1 is synchronous traction motor, 2 is asynchronous traction motor speed-torque characteristics, 3 is individually excited shunt-wound DC traction motor, 4 is series wound DC traction, speed-torque characteristics; $\Delta n_{1}$ is asynchronous traction motor speed variation; $\Delta n_{2}$ is separately excited shunt - wound DC traction motor speed variation; $\Delta n_{3}$ is series wound $\mathrm{DC}$ traction speed variation.

Variation in load moment causes variations in speed. For locomotive traction force and wheelsets slip requirements in starting mode the best is synchronous traction motor speed-torque characteristic. Figure 21 shows the speed-torque characteristic (1) curve of a synchronous traction motor. In the speed-torque characteristic, the torque is usually shown dependent on the speed. Asynchronous traction motor and separately excited shunt-wound DC traction motor speed-torque characteristics, a variation in load moment is similar-sized tolerance (Figure 21, $1^{\text {st }}$ and $3^{\text {rd }}$ curves). Locomotives with these traction motor speed-torque characteristics rarely comprise wheelset slip conditions. The $4^{\text {th }}$ curve in Figure 21 shows that for locomotives with DC series-wound traction motors anti-slip systems must be used, because when it is operated without load, torque speed increases very quickly.

Figure 21 shows the speed-torque characteristic $2^{\text {nd }}$ curve of a three-phase asynchronous traction motor. In the speed-torque characteristic, the torque is usually shown dependent on the speed. There $M=0$ when the motor is idling. If a load is applied to the motor, the speed drops and the torque increases. The maximum torque which a motor can produce is known as the pull-out torque. 


\subsubsection{Parallel operation and control peculiarities of AC traction motors}

The principal scheme of AC/AC electrical system locomotive electrical drive when three asynchronous traction motors of one bogie are powered from the common frequency converter FC is shown in Figure 22. The peculiarities of parallel operation of traction motors are analyzed at the same static resistance moment $M_{s t}$. Due to the inevitable geometrical deviations of parts (wheelset, rail), differences of electrical and magnetic properties of materials, the characteristics of the same type traction motors are different. In the nominal load mode, the traction motor rotor speeds may differ by $\pm 3 \%$. When asynchronous traction motors are powered from one source, the currents among parallel traction motors are redistributed due to the natural mechanical characteristics of the same type asynchronous traction motors. Traction motors achieve different respective torques $M 1, M_{2}, M_{3}$, rotor rotation speeds $n_{1}, n_{2}, n_{3}$ and develop different traction forces of individual motors.

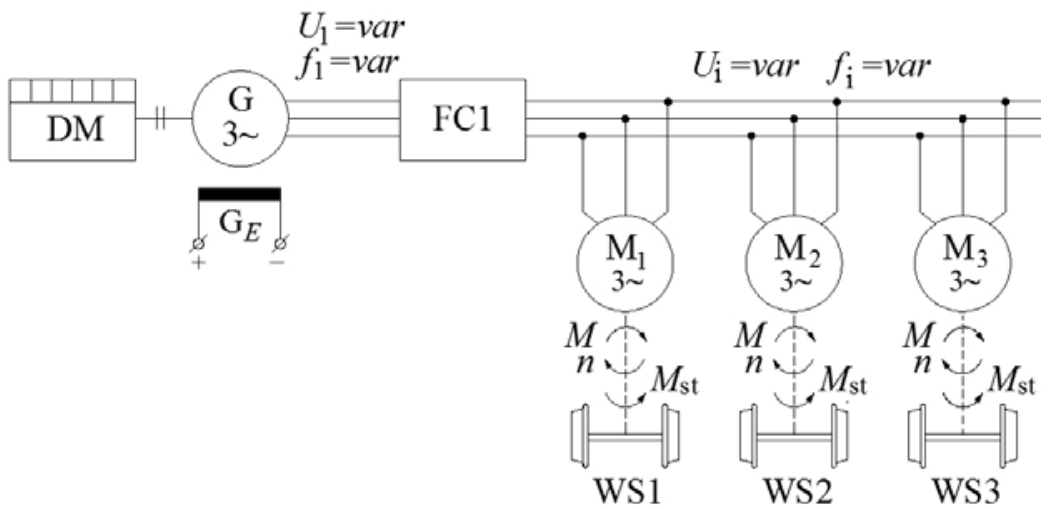

Figure 22. Circuit diagram of diesel-electric powered locomotive (AC/AC current system) drive, when one frequency converter is used to power three $\mathrm{AC}$ traction motors: DM is diesel engine; $\mathrm{G}$ is synchronous traction generator;

$\mathrm{FC} 1$ is frequency converter; M1, M2, M3 are asynchronous traction motors; WS1, WS2, WS3 are wheelsets; $\mathrm{M}_{\mathrm{st}}$ is static resistance torque; $\mathrm{U}_{1}, \mathrm{f}_{1}$ are asynchronous traction motor drive parameters.

Natural mechanical characteristics of the same type ATM at the same static resistance torque $M_{s t}$ at the wheelset force point A are shown in Figure 23.

Natural mechanical characteristics of the same type ATMs may be formed at the point where synchronous speed is $n_{0}$. When analysing natural mechanical characteristics of the same type asynchronous torque motors with the same static resistance torque $M_{s t}$ at the wheelset force point A, it can be seen that the rotation speed of the first ATM rotor $n_{1}$, rotation speed of the second ATM rotor $n_{2}$, and rotation speed of the third 


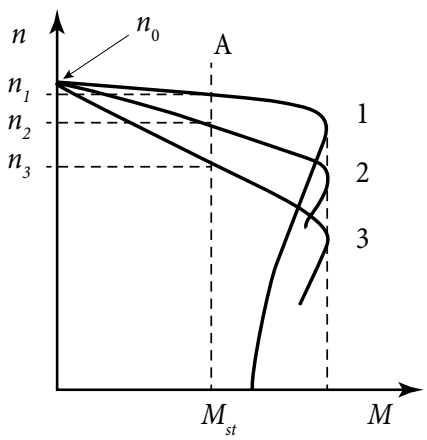

Figure 23. The same type natural mechanical characteristics of asynchronous traction motors at the same static resistance torque

ATM rotor $n_{3}$ do not synchronize. When the wheelset diameter is equal and the speed of traction motor rotor is different, the distance travelled by wheelsets is different. This phenomenon causes wheelset slip conditions and redistribution of traction forces.

\subsubsection{Control systems of asynchronous motors with individual frequency converters}

Control systems of locomotive traction asynchronous motors with individual frequency converters are shown in Figure 24.

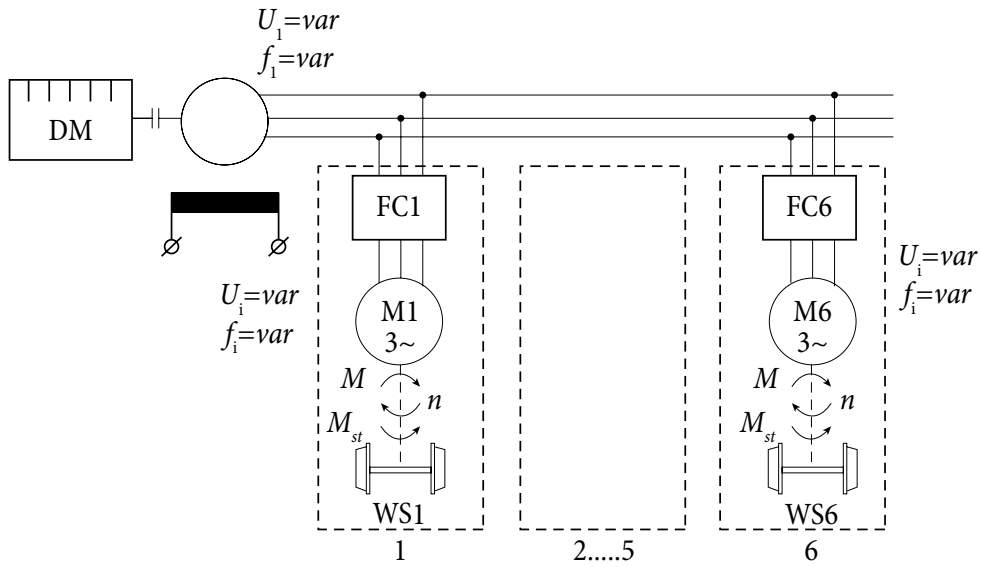

Figure 24. Control system of asynchronous engines with individual frequency converters: FC1, ..., FC6 are frequency converters; WS1, ..., WS6 are wheelsets of locomotive.

When using ATM control via individual frequency converters, the slipping and sliding process is easier to control as the speed of every traction motor can be adjusted separately. However, this control system is often more complex and less reliable. 


\subsubsection{Frequency control peculiarities of locomotives with asynchronous traction motors}

For locomotives with frequency converter mode of ATM that satisfies traction theory requirements, there is a need to change the nature of natural mechanical characteristics artificially by developing a part of hyperbolic function. Thus ATM areas of the natural characteristics are shown as $A_{1}, A_{2}, A_{3}$ (Figure 25). The nature of ATM artificial mechanical characteristics corresponds to DC series excitation DC traction motor mechanical characteristics. Therefore, locomotives with ATMs should have installed control systems to control wheelset slipping process. During locomotive wheelset slipping, they temporarily change the nature of the ATM artificial mechanical properties and recover the conditions of wheelset adhesion with rails. Computer-aided control systems for locomotive wheelset slipping and sliding process control that is proposed by the authors will change the nature of ATM artificial mechanical properties, and it will automatically recover good conditions of wheelset adhesion to rails. Adjusted ATM dynamic mechanical properties with applied frequency speed control method are provided in Figure 25 (in green).

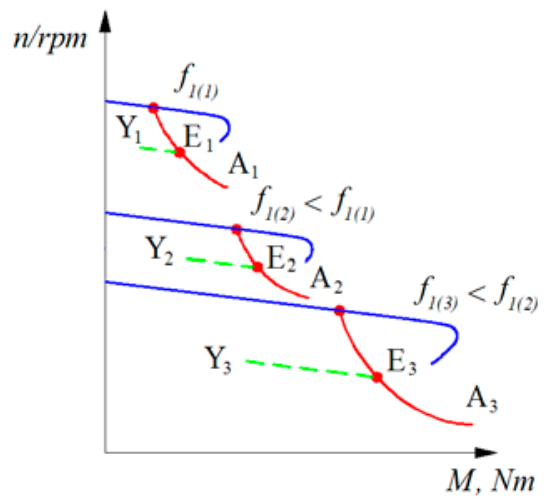

Figure 25. Artificial asynchronous mechanical characteristics of asynchronous motor when ATM frequency rotation speed control method is applied

\subsubsection{Automatic control of slipping process of locomotives with AC traction motors}

Figure 26 shows $\mathrm{AC} / \mathrm{AC}$ system that is proposed by the authors for computer-aided control of $\mathrm{AC} / \mathrm{AC}$ system of locomotive wheelset slipping and sliding process that is comprised of wheelset speed sensors BR1- BR6 that are mounted in traction motors, A and B bogie wheelset speed tolerance signal comparison blocks SCBI, SCBII (Liudvinavičius and Lingaitis 2010). When the tolerance of one of the individual wheelsets of bogies (A or $\mathrm{B}$ ) is exceeded, there are generated control signals A and B that adjust signals sent by computer-aided control system (in Figure 26 marked respectively as $\mathrm{X}_{\mathrm{A}}$ and $\mathrm{X}_{\mathrm{B}}$ ) to inverter 
elements IGBT transistors that have changing on and off cycles (Strekopytov et al. 2003).

The automatic control system of slipping process that is proposed by the authors will decrease the value of supply power and its frequency of one bogie from the three asynchronous engines for a short time. Thus the rotation speed of one bogie of traction motor-wheelset shall be equalized and wheel-to-rail adhesion shall be restored. Such dynamic characteristics are shown in Figure 25 in green as $E_{1}-Y_{1}$ with supply power frequency $f_{1}(1) . \mathrm{E}_{2}-\mathrm{Y}_{2}$ at supply power frequency $f_{1}(2), \mathrm{E}_{3}-\mathrm{Y}_{3}$ with supply power frequency $f_{1}(3)$. When adhesion conditions are restored, there is automatic restoration of ATM supply power and its frequency value, i.e. it returns to any point of the previous operating characteristic (Figure 25, in red). Traction forces are not disrupted in locomotive control process as slipping process is controlled automatically.

\subsubsection{Algorithm for slipping process parameter adjustment and control}

The authors provide computer-aided control system of locomotive wheelset slipping and sliding process control presented in Figure 26. Variants of the control algorithm: a) wheelset speed tolerance signals are compared with the tolerance signals in blocks SCBI, SCBII and they are adjusted by changing parameters of that inverter to control signals $\mathrm{Y}_{1}$ and $\mathrm{Y}_{3}$ (thereof the respective three asynchronous traction engines (individual controlled) are powered); b) in case with controlled parameters of inverters I and II the process of bogie wheelset slippage is continued and bogie wheelset speeds are not equalized, the generator voltage of synchronous traction motor is limited by decreasing excitation current with signal $\mathrm{Y}_{2}$ (general parameter control).

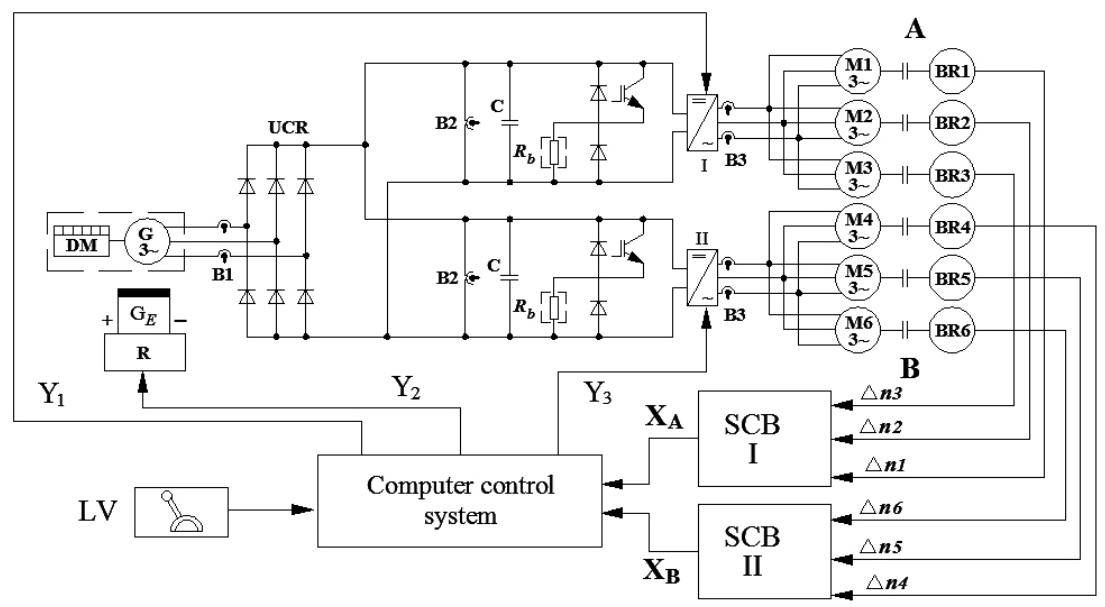

Figure 26. Circuit diagram of diesel-electric powered locomotive (AC/AC electric system) automatic wheelsets anti-slip and slide control system process parameters computer drive 


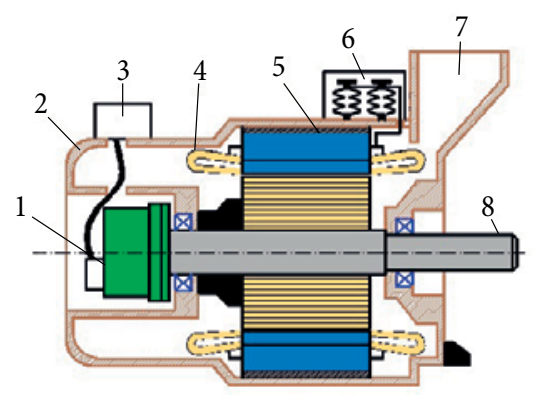

Figure 27. Asynchronous traction motor with internal optical encoder: 1 is encoder; 2 is stator; 3 is terminal box; 4 is stator windings; 5 is ferromagnetic core; 6 is clamps; 7 is cooling channel; 8 is shaft.

Computer-aided control system of AC/AC current system diesel locomotive wheelset slipping-sliding process consists of (Figure 26): DM is diesel engine; $\mathrm{G}$ is synchronous traction generator; I, II are frequency converters; UCR-uncontrolled rectifier; M1, ..., M6 are asynchronous traction motors; speed sensors of BR traction motors; LD is locomotive driver; SCBI is bogie A wheelset speed tolerance signal comparison unit; SCBII-B is bogie wheelset speed tolerance signal comparison unit; $Y_{1}$ is control signal that adjusts inverter I electrical parameters; $Y_{2}$ is synchronous traction motor signal that adjusts generator excitation current; $Y_{3}$ is control signal that adjusts inverter II electrical parameters; $R$ is excitation current regulator of synchronous traction generator; $G_{E}$ is excitation winding of synchronous traction generator; $\Delta n_{1}, \ldots, \Delta n_{6}$ are speed tolerance signals of traction motor; $X_{\mathrm{A}}$ is total compared bogie A wheelset speed tolerance signal; $X_{\mathrm{B}}$ is total compared bogie B wheelset speed tolerance signal.

The authors propose to install an encoder in ATM rotation speed and location coordinate measurement sensors BR that are installed in the traction motor (see Figure 27). The encoder is an analogous or digital converter with analogous signal at the output or a certain number of pulses that is proportional to rotation speed or turn angle (Precision inductosyn ... 1996).

To use an encoder in the ATM vector control system is suggested by Lingaitis and Liudvinavičius (2006). The encoder consists of a light source, mask, code disk, and sensors. The code disc contains artificial spaces that make light permeable and impermeable segments. Light sensitive sensors are mounted behind the code disc. The scheme of the optical encoder is provided in Figure 28 (Fuest and Döring 2007, Encoder catalogue 2003). 


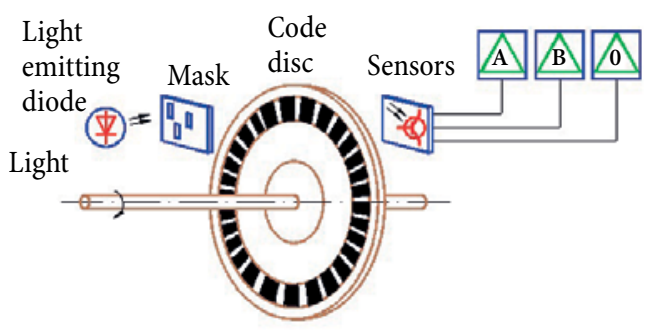

Figure 28. Optical encoder scheme

When the encoder is installed in the ATM control system that is proposed by the authors, there can be received analogous or digital information, thus developing analogous-digital (hybrid) locomotive electrical drive control system (Antoniak 1990; Stolting 2002).

Pursuant to the purpose, the encoder may contain various codes: binary code, Gray code, Gray-express code (Braess 2000). All of them are suitable for computer system of $\mathrm{AC} / \mathrm{AC}$ current system diesel locomotive wheelset slipping-sliding process control that is proposed by the authors.

\subsubsection{Tests of locomotive wheelset slipping and sliding process computer-aided control and management system}

\section{Locomotive drive tests description}

The software performs the several tasks. It ensures highly efficient wheel-to-rail force transmission by means of continuous wheel force at its rim, slip control, limitation of wheel acceleration, reliable determination of the reference speed, which should represent the true train speed.

The software protects the mechanical components against excess stress and reduces wear on the rails and wheelset by avoiding wheel blocking (flat spots on the running surface), synchronous drifting of the wheel speeds (worn rail heads), and inherently stable rotational vibrations in the drive train.

The software continuously monitors the movement of the vehicle and the running wheels. If the movement variables deviate from the tolerance values, the tractive effort demanded by the overall control level is automatically reduced to a level which can be physically transmitted from the wheel to the rail.

Due to continuous monitoring of the movement variables relating to the vehicle and the wheels, it is ensured that traction is kept under control under different track conditions. 
Power mode: The test train is accelerated from standstill to maximum speed. All wheel speeds are monitored via the data logger to confirm the proper functionality.

Dynamic brake only: The test train is decelerated from maximum speed to standstill with the dynamic brake.

Dynamic and pneumatic brake: The test train is decelerated from maximum speed to standstill with the dynamic and the independent brake.

This is not a normal service operation. It shows that the wheel slide is corrected via signals transmitted from the pneumatic wheel slide system to the Locomotive Computer Unit for the limitation of electric brake in case of active pneumatic brake.

\subsubsection{Conclusions:}

1. The non-traditional computer-aided slipping and sliding control system of locomotive AC traction motors that is proposed by the authors allows automatic continuous control of electrical parameters of the inverter and traction generator in traction mode (dynamic mode) with the simultaneous slipping process control.

2. When the provided slip and slide control system of locomotives with AC traction motors is used:

1) the train driver does not need to interrupt traction mode control and this way there are no conditions for the formation of the rolling stock longitudinal tensile and compression forces;

2) there is optimal locomotive traction force control;

3) there are less energy transformation losses in locomotive powertrain;

4) the wheel/ rail adhesion coefficient is little dependent on the season; and

5) the wheel/ rail adhesion coefficient is recovered automatically and there is no need to spread the sand under the wheels to increase the adhesion.

\subsection{Research on diesel locomotives with DC traction motors wheelsets' slipping and sliding control}

The causes of slipping and sliding of the locomotive's driving wheelsets are analyzed from theoretical and practical perspectives. The main factors influencing wheelsets' slipping are described, and their correlation is determined. The specific methods of stopping the slipping of the diesel locomotives having a conventional electric drive system are described in Polach (2005), Zhang et al. (2002), Ohyama et al. (1989), and Ohyama (1982). The control of the dynamic locomotive wheelsets' slipping and sliding, based on the evaluation of the influence of the speed-torque characteristics of DC traction motors on these processes, are presented in the structural diagrams below. Major 
parameters of the DC/DC and AC/DC systems used in the automatic control of the dynamic slipping and sliding of the locomotive's wheelsets are defined and new methods of controlling the dynamic slipping and sliding are suggested by the authors.

The efficiency of transportation by railways largely depends on railway track capacity. A railway operator has to ensure steady and safe traffic, as well as the effective use of the locomotive power. The problems associated with the comfort of passenger trains were investigated by Inarida et al. (2001), while the parameters of electrodynamics braking and power systems of the trains were considered by Liudvinavičius et al. (2007) and (2009). To ensure a steady traffic flow of trains (particularly, heavy freight trains), the tractive force of the locomotive should be effectively controlled. It is important to control the locomotive so that its tractive force is uniform and its development is not interrupted because of the driving wheelsets' sliding. The conditions for the wheelsets to slide are usually created when a heavy train starts moving or is moving uphill (Bureika 2008). In this case, the locomotive is moving so that the driving wheels' spin speed sharply increases, while the tractive force of the locomotive decreases fast, causing a sharp slowdown of the straight-line motion of the train, which may even stop between the stations.

When the adhesion coefficient is decreased considerably, the locomotive's tractive force is not sufficient to pull the train. In this case, sand is spread on the rails to increase the adhesion coefficient. However, the starting time of a locomotive increases due to intense slipping of the wheelsets, which causes more intense wearing out of both of the wheelsets and rails. A number of researchers study the problem of the effective control of the locomotive's tractive force, for example, Dailydka et al. (2008) and Djukič et al. (2010).

Slipping of the locomotive's wheelsets depends on the angle of taper of the wheels' rolling surface as well as the slope of the track and the wheelset position with respect to the longitudinal axis of the rails. When a locomotive is moving in the traction mode, the axle load of the locomotive's powered wheelsets acting on the rails is redistributed, and this is one of the main causes of slipping and sliding of the wheels.

The effect of the variation of the coefficient of adhesion between the wheels and the rails on the tractive effort characteristic, as well as the operation of electric traction motors and the effect of their arrangement in the carriage on the static wheel-to-rail force, are also very important. Another relevant problem is the adjustment and control of the parameters of the wheelsets' slipping and sliding in the case of various types of the locomotive drives, such as DC/DC, AC/DC and the latest type of AC/AC drives. The operation of these drives is described in the works of Lingaitis et al. (2006), Strekopytov et al. (2003), Sen (1996), Liudvinavičius et al. (2009) and Nayal et al. (2006). In order to effectively control slipping and sliding of the DC motor-driven wheelsets, 
the mechanical characteristics of motors and the effectiveness of the methods of speed regulation of the rotors of these motors should be determined. The algorithms for automating the control of the electric motors were considered by Yamaguchi (2006).

Assuming that the mechanical characteristics of the DC traction generators may have a certain influence on slipping, the structural control diagrams of the processes of slipping and sliding of the wheels were developed in the course of investigation. Based on the analysis of the main factors contributing to slipping, and, given the parameters of this process, the modeling of wheelsets' slipping and its control methods was performed.

When the driving wheelset starts sliding, it makes more revolutions and, theoretically, due to the specific mechanical characteristics of the DC traction generator, the rotor (and the wheelset) may 'race'. In practice, the process lasts until the mechanical failure of the electrical motor's armature takes place. The more revolutions the wheel makes, the higher is the slipping, while the tractive force of a locomotive drops to zero. The authors investigated the mechanical characteristics of the DC traction in order to find the ways of avoiding the unwanted drop of the tractive force.

\subsubsection{Theoretical assumptions of the locomotive wheelsets' slipping and the consequences of the wheelsets sliding on the track}

High adhesion utilization and sophisticated dynamics design of modern locomotives and traction rolling stocks demand complex simulations which at the same time take into consideration the mechanical, electro-technical, and traction control system field. When the locomotive's tractive force exceeds the adhesion of the wheels to the rails, slipping of the locomotive's wheelsets may start. In vehicle dynamics, small slip values (microslip) are of main importance. The correct description of the resulting traction coefficient between wheel and rail is important for investigations related to wear, rolling contact fatigue, traction control, or running stability analyses. Furthermore, information about local mechanical and thermal load distributions within the contact zone is desirable. A profound description of the state of the art of dynamical contact problems with friction can be found in Sextro (2007). Longitudinal and lateral slip as well as spin slip should be taken in account (Polach 2005).

The adhesion coefficient is a variable and it strongly affects traction. The variation of the wheel-to-rail adhesion coefficient $Y$ of the locomotive is given for various seasons in Figure 16.

To determine the adhesion coefficient of a new locomotive, field tests are carried out in various seasons and ar various times of the day. Several hundred tests should be performed to obtain accurate results. In Figure 16, it is shown that the adhesion coefficient varies considerably, even if the mass of the locomotives is actually the same. It depends 
on many factors, including rain, snow, the contamination of the rails by the oil products, wearing of the rolling surface of the wheel and the rails, the track profile, etc.

"Conventional" contact models like CONTACT (Kalker 1967), deduced simplifications such as FASTSIM (Kalker 1982), or analytical derivatives of the model (Polach 2005) are able to describe the principal mechanisms linked to the stick and slip zones within the contact rail/wheel, and are therefore capable of describing the characteristic correlation between locomotive traction coefficient and slippage. The friction coefficient between wheel and rail has to be provided by the user. This coefficient is highly dependent on parameters such as wheel rolling velocity, normal axle load, microscopic surface roughness of wheel and rail, etc. Moreover, these parameter influences are strongly dependent on the lubrication state of the contact, whether the contact is humid, i.e. boundary lubricated, dry or in mixed lubrication state, where enough fluid is present between wheel and rail to build up a positive fluid pressure regime.

With emphasis on the lubrication only, sophisticated models for elastic-hydrodynamic lubrication (EHL) have been developed and extended to the application to rough surfaces (Patir and Cheng 1978). These researchers introduced flow factors to averaged Reynolds equations for an application to rough surfaces. This method is applicable to the full and mixed lubrication regime, where the fluid fully occupies the area between the two contacting bodies, causing hydrodynamic lift. The method was applied to isothermal rolling contact and the adhesion coefficient was approximated (Chen et al. 2005). A tangential contact model was not employed. A method to use this model even under boundary lubrication conditions is proposed in $\mathrm{Hu}$ and $\mathrm{Zhu}$ (2000).

The interfacial fluid model presented by Tomberger et al. (2011) can be used in combined mixed and boundary lubricated contacts. A new approach is the consideration of the metallic volume occupation by the surface roughness peaks, called asperities. This interfacial fluid model is based on the continuity equation, a pressure-mass flow relation and an abstraction of the surface geometry.

A possible explanation of the decreasing of slip force-slip function for large longitudinal slip is the decrease of friction coefficient with increasing slip speed due the increasing temperature in the rail-wheel contact area (Hou et al. 2000; Ertz and Bucher 2002; Ertz and Knothe 2002). With increasing slip, the temperature in the rail-wheel contact area increases and the coefficient of adhesion decreases.

Another explanation is different friction coefficients in the area of adhesion and area of slip (static kinematic friction coefficient) does not seem to sufficiently influence the shape of the slip force curve (Ohyama et al. 1989; Nielsen and Berthier 1996)

The method described by Polach (2005) allows simulating slip force according to measurement for various conditions-dry, wet, contaminated, etc. It is based on the fast 


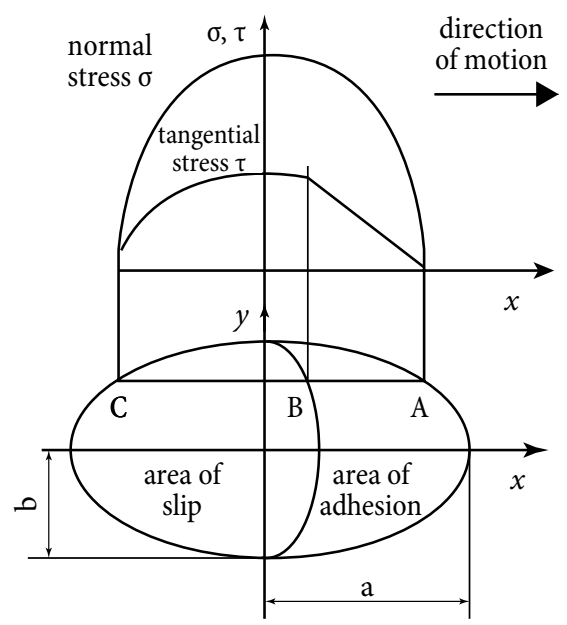

Figure 29. Distribution of normal and tangential stresses in the rail-wheel contact area in Polach (2005) method

method for calculation of wheel-rail forces developed by Polach and largely tested and used in various three dimensional multi-body simulation tools.

This method developed by Polach for calculation of slip forces in multi-body simulations (Polach 1999, Kalker 1982) is based on a theoretical model for longitudinal and lateral slip, assuming a coefficient characterizing the rail-wheel contact shear stiffness.

The rail-wheel contact area is assumed elliptical with half-axes $a, b$ and normal stresses $s$ distribution according to Hertz. The distribution of tangential stress $t$ is shown in Figure 29.

The maximum value of tangential stress at any random point is:

$$
\tau_{\max }=\mu \cdot s
$$

where: $\mu$ is the coefficient of wheel/rail friction.

The forces $\mathrm{F}_{\mathrm{x}}, \mathrm{F}_{\mathrm{y}}$ in longitudinal and lateral directions are:

$$
F_{i}=F \cdot \frac{s_{i}}{s} ; i=x, y \text {; }
$$

and the adhesion coefficient:

$$
f_{i}=\frac{F_{i}}{Q} ; i=x, y ;
$$

where: $F$ is the total contact force, $\mathrm{kN} ; s$ is the total slip; and $Q$ is the wheel load, $\mathrm{kN}$.

A slip force law with a marked adhesion optimum can be modeled using the friction coefficient decreasing with increasing slip (creep) speed between rail and wheel (Zhang et al. 2002). 
In additional, the reduction of the initial gradient of slip force curve explained by Bucher et al. (2002) through the influence of the surface roughness, and by Harrison et al. (2000) on the effect of surface's contamination can be used.

A large longitudinal slip between wheel and rail occurs for the adhesion limit, in particular for the maximum transmissible tractive forces. Using the theory of friction coefficient decreasing with increasing slip by the influence of temperature for the case of wet or polluted contact conditions, the only way to achieve the adhesion optimum at large slip values is a significant reduction of the coefficient of Kalker's linear theory (Polach 2005). With increasing slippage, the temperature in the contact area increases and the coefficient of friction decreases.

Typical values of the reduction factor for real rail/wheel contact conditions as evaluated from measurements are $0.2-0.5$ for wet rails and $0.6-0.85$ for dry rails. It should be noted, the only use of decreasing adhesion coefficient does not allow simulating the slip forces between wheel and rail in complex dynamics simulations, is when transmitting the limiting tractive force under unfavorable adhesion conditions. The proposed model by Polach (2005) of real slip forces for wet, polluted, or dry rail is based on a combination of dry and wet friction.

Large slip occurs mainly on the longitudinal direction because of traction or braking; the maximum lateral slip cannot reach the level of maximum longitudinal slip due to traction or braking.

The definition of the tangential failure stress $\tau_{\mathrm{m}}$ is, however, difficult. In addition to the mechanism of adhesion, plastic asperity deformation, ploughing and other dissipative mechanisms, boundary lubrication and influences of solid interfacial layers have an effect on the tangential failure stress of a contact. Furthermore, so-called third bodies, forming a solid interface between the contacting bodies, can alter the friction process (Berthier et al. 2004; Niccolini and Berthier 2005).

A run on the unstable (decreasing) section of slip force curve was simulated by Polach (2000). With increasing tractive effort, the wheelset steering ability decreases. Simultaneously, the first wheelset of the bogie moves to the inner rail.

Measurements under water lubricated conditions report a distinct decrease of the maximum traction coefficient with increasing rolling velocities (Zhan et al. 2002; Ohyama and Maruyama 1982; Chen et al. 2008). No velocity dependence is reported in the paper by Ohyama et al. (1989) for a boundary-lubricated contact, using paraffinic-oil.

Researchers Mei, Yu and Wilson (2009) propose a radically new approach for the detection of wheel slip/slide and re-adhesion control of AC traction motors in railway applications, which provides an important alternative and advantageous technique in traction/braking control systems to maximize the use of adhesion in poor rail-wheel contact conditions. The proposed concept explores the variations in the locomotive 
wheelset dynamic properties caused by the condition changes at the wheel-rail contact, and detects and controls the slip conditions from the dynamic behaviour of a wheelset, indirectly. The influence of contact conditions on the relevant modes is assessed, which is essential in the development of a mechatronic solution based on dynamic interactions.

At the current stage of development, the above described models (also methods presented in books by Andersson (2007), Iwnicki (2006), and Wickens (2003) can be widely used for investigations related to the development of locomotives traction (slip and slide) control strategies and rail/wheel wear or rolling contact materials fatigue.

\subsubsection{The effect of the speed-torque characteristics of the DC traction motor of a locomotive on slipping and sliding of the wheels}

\section{Speed-torque characteristics of the locomotive's DC traction motor}

In Sen (1996), the main principles of electric motor operation and control are described. Circuit diagrams (Series-wound DC traction motor circuit diagram and separately excited shunt-wound DC traction motor circuit diagram) as well as their speed-torque characteristics are presented in Figure 30 and Figure 31.

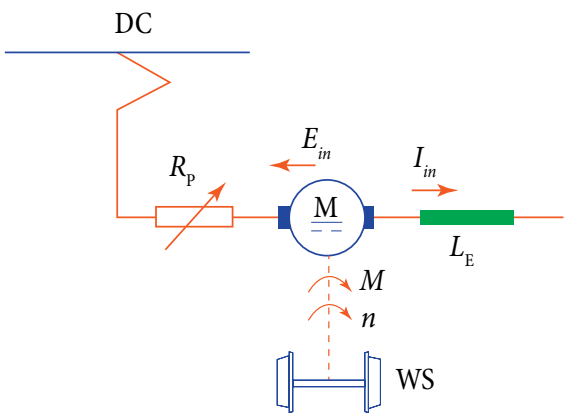

Figure 30. A circuit diagram of a series-wound DC traction motor: $I_{\text {in }}$ is armature current; $E_{\text {in }}$ is armature voltage; $M$ is the electromagnetic moment in the traction mode; $n$ is DC motor's rotor speed; $L_{\mathrm{E}}$ is an exciting winding; WS denotes wheelsets; $R_{\mathrm{P}}$ is the resistor.

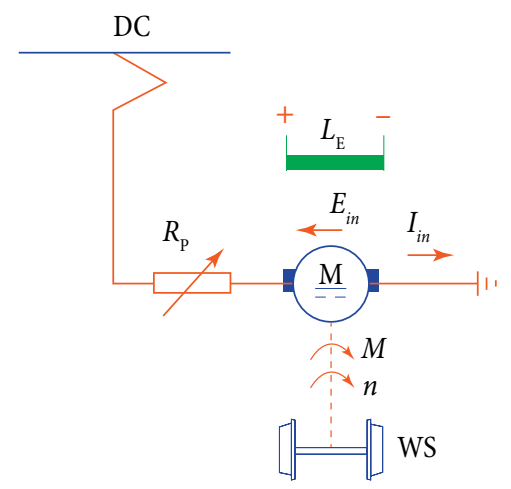

Figure 31. A circuit diagram of a separately excited shunt-wound DC traction motor: $I_{\mathrm{in}}$ is armature current; $E_{\text {in }}$ is armature voltage; $M$ is the electromagnetic moment in the traction mode; $n$ is the traction motor's rotor speed; $L_{\mathrm{E}}$ is an exciting winding; WS denotes wheelsets; $R_{\mathrm{P}}$ is the resistor. 
The variation of the rotor speed of the series-wound and shunt-wound DC traction motors, depending on the axle load, is shown by the curves depicted in Figure 32.

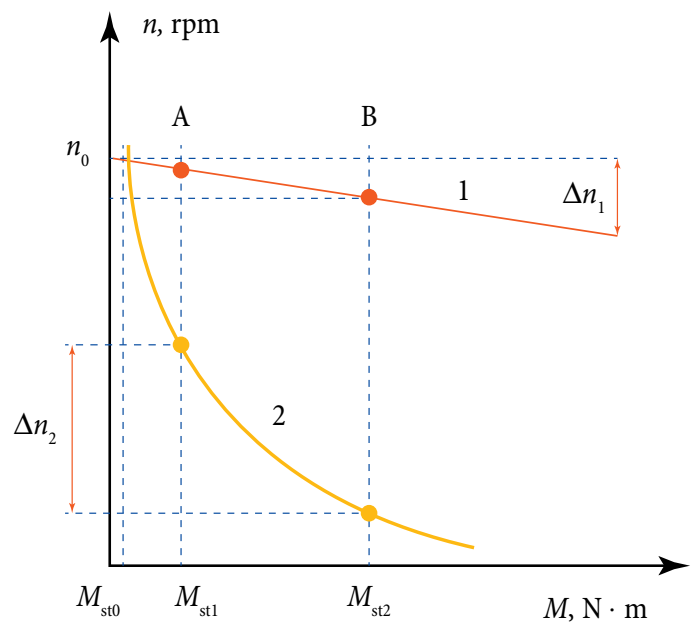

Figure 32. Speed-torque characteristics of the separately excited shunt-wound (1) and series-wound (2) DC traction motors: $M_{s t 0}, M_{s t 1}, M_{s t 2}$ denote static load torque of a DC traction motor; $n_{\mathrm{o}}$ is no-load armature speed of a separately excited shunt-wound DC traction motor

Series-wound DC machines are used as motors and generators. Series-wound traction motors have a very high starting torque. The speed of the DC series-wound motor is strongly dependent on the load. A variation in load causes a variation in current. If the load is increased, the current increases and the speed is reduced. During the startup and on high load, the series-wound traction motor consumes a high current, which produces a powerful torque.

They may never be operated without the load torque because they may 'race' on no-load. A series-wound traction motor cannot be operated on no-load under any circumstances because it increases its speed to such a degree that the armature is destroyed, i.e., it 'races' on no-load (see Figure 32).

In a DC series-wound traction motor operating without the load torque, the rotor speed increases very quickly and the wheelsets start slipping. The analysis of the speedtorque characteristics of the DC series-wound and separately excited shunt-wound traction motors at the points A and B allows us to state that the rotor speed of a separately excited shunt-wound traction motor is hardly dependent on the load (speed variation $\Delta n_{1}$ ), while speed variation $\Delta n_{2}$ of a series-wound DC traction motor is much higher. In addition, as shown in the curve 2 in Fig 30, a series-wound DC traction motor cannot operate on no-load. Traction motors of the latter type are commonly used in locomotives. When the wheel-to-rail forces are redistributed for the reasons discussed above, the speed of the less heavily loaded wheel increases fast, causing the development of 
slipping and sliding of the wheelsets. The locomotives with the DC series-wound traction motors must use anti-slip systems.

\subsubsection{Wheel-to-rail adhesion of the locomotives with separately excited shunt-wound and series-wound DC traction motors}

The authors analyse wheel-to-rail adhesion for the locomotives using separately excited shunt-wound (characteristic 3 ) and series-wound (characteristic 2) DC traction motors (see Figure 33). The curve $F_{k s}$ corresponds to the boundary tractive force characteristic depending on adhesion. At the point $\mathrm{A}$, the boundary tractive force depending on adhesion is found, while the locomotive speed is $v$. If the adhesion is weaker, e.g. on the contaminated track section, the tractive force depending on adhesion is decreased by the magnitude $\Delta F_{k s .}$. Therefore in this case, the tractive force will be higher than the adhesion force, and the wheelsets will start slipping and sliding on the track.

When the angle speed of a wheelset of the locomotive with a separately excited shunt-wound DC traction motor increases, the tractive force of the locomotive sharply decreases, getting equal to the tractive force depending on adhesion at the point $\mathrm{B}$. In this case, the wheelset's slipping rate $\Delta v_{1}$ is low. However, the value of the friction coefficient remains high and, therefore, the wheelsets, after passing over the reduced adhesion area, will regain the proper adhesion.

In a similar case with a series-wound DC traction motor, its tractive force and tractive force depending on adhesion are equal at the point $\mathrm{C}$, where the slipping rate of the wheelset $\Delta v_{2}$ is high, while the friction coefficient is low.

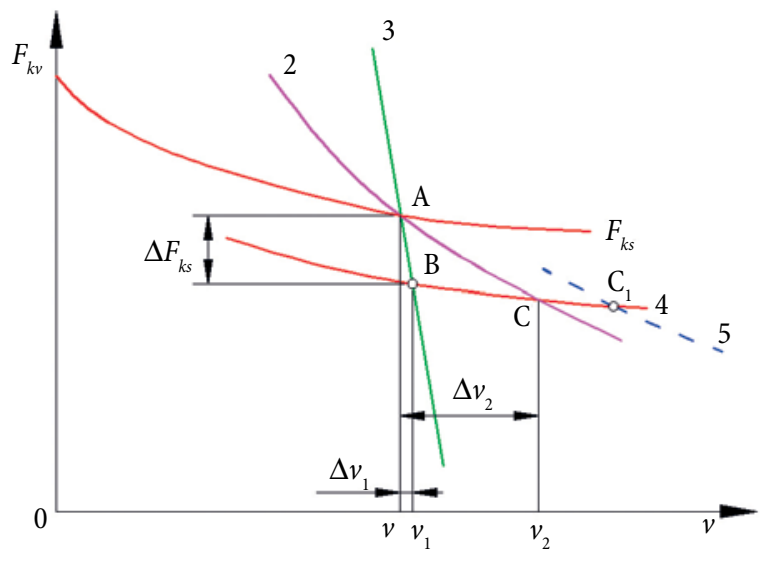

Figure 33. The effect of speed-torque characteristics on the tractive force of a locomotive, depending on adhesion 
In this case, the conditions for regaining the proper adhesion without any external help are much worse. Therefore, the spreading of sand in the reduced adhesion area is required for the wheelsets to regain good adhesion to the rails. The latter is faster regained by the locomotives with separately excited shunt-wound DC tractive motors. Therefore, their average tractive force, depending on adhesion, is higher than that of the series-wound DC traction motors. The locomotives with separately excited shuntwound DC traction motors have a higher wheel-to-rail adhesion coefficient compared to those having series-wound DC traction motors, whose low adhesion coefficient is compensated for by the use of slipping and skidding protection systems.

\subsubsection{Protecting the driving wheelsets of a locomotive from skidding}

\section{A scheme of the mechanical compensating system of wheel-to-rail force redistribution}

In Figure 34, a scheme of the mechanical compensating system of wheel-to-rail force redistribution for a locomotive operating in the traction mode is given. A system consists of the pneumatic cylinders located perpendicular to the outward wheelsets of the first and the second bogie. When the locomotive starts moving, the compressed air is supplied to the front cylinders (with respect to the direction of movement), denoted by 1 (Figure 34), and their shafts squeeze the frames of the bogies. In order to balance the moment $M_{T}$, occurring when the locomotive is moving along the curved track, the first wheelsets of the respective bogies are pressed. The system is automated, which implies that a special regulator changes the pressure in the system, depending on the tractive force. A pressure regulator is controlled by the pressure relays connected to the network of the traction motors. The higher the current in the network of traction motors and pressure relays, the higher the tractive force of a locomotive and, therefore, more

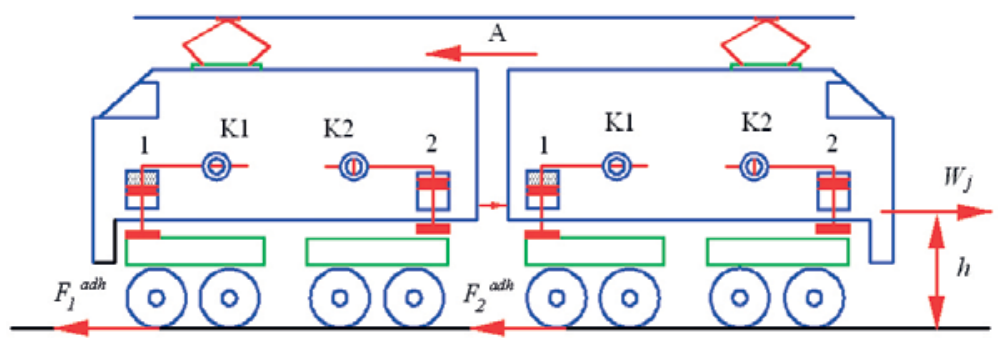

Figure 34. A scheme of a compensating system of the wheel-to-rail forces' redistribution in a locomotive operating in the traction mode: $F_{1}{ }^{a d h}$ and $F_{2}{ }^{\text {adh }}$ are powered wheel tractive efforts; $W_{j}$ denotes the resistance tractive effort at the locomotive's automatic coupling; $h$ is the distance (height) from the rail head to the automatic coupling; 1 denotes the hydraulic cylinders; $K_{1}, K_{2}$ are the valves; $A$ denotes 
highly compressed air is supplied to the pneumatic system. Depending on the direction of the locomotive's motion, the valve $\mathrm{K} 1$ or $\mathrm{K} 2$ is opened. By controlling the position of the valves $\mathrm{K} 1$ and $\mathrm{K} 2$ and pressure in the cylinders, the forces compensating for the decrease of the axle loads of the bogies are generated. These forces 'press' the bogies to the rails, thereby increasing the adhesion coefficient of the locomotive.

The mechanical system of the wheelset load compensation is rather complicated. The variation of the axle loads should be controlled by the sensors, while the pressure in particular cylinders should be regulated by the valves. The electric system of protecting from slipping and sliding suggested by the authors may supplement the mechanical system of the wheelset load compensation.

\subsubsection{A conventional slip and slide protection system for diesel-electric (DC/DC) locomotives}

During the slipping and sliding of the powered wheelsets the adhesion coefficient of the wheelsets to rails decreases, thereby decreasing the locomotive tractive force. Therefore, the locomotive wheelsets' adhesion to the rails should be closely watched and adequately controlled to protect them from slipping (Braess and Seiffert 2000).

Usually, the parameters of the locomotive slipping are continually measured and adjusted by specially installed automatic control systems of the electric drives. The main causes of slipping and sliding of the wheelsets of the locomotives with the DC traction motors connected in series are as follows: redistribution of loads (armature current) due to mismatch of the characteristics of traction motors of the same type and different wheel-to-rail forces in the same locomotive, as well as due to various types of the mechanical characteristic of a traction motor. The mechanical speed-torque characteristic

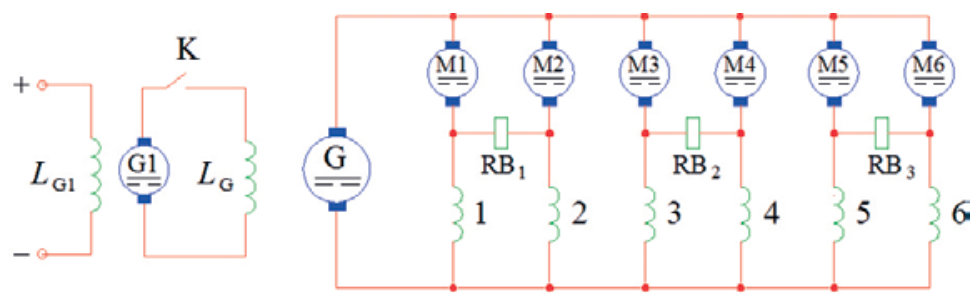

Figure 35. A circuit diagram of the relay wheelsets' slip and slide protection system in a conventional diesel-electric locomotive (of DC/DC type): $\mathrm{G}$ is a separately excited shunt-wound $\mathrm{DC}$ traction generator; $\mathrm{G} 1$ is the exciter; $\mathrm{L}_{\mathrm{G}}$ is the exciting winding of a $\mathrm{DC}$ traction generator; $\mathrm{L}_{\mathrm{G} 1}$ is the exciting winding of the generator's exciter; $\mathrm{R}_{\mathrm{B} 1}, \mathrm{R}_{\mathrm{B} 2}$, $\mathrm{R}_{\mathrm{B} 3}$ are the relays for controlling the process of the locomotive slipping; $1, \ldots, 6$ are the exciting windings of the DC traction motors; M1...M6 are the DC traction motors; and 
of series-wound DC traction motors used in the DC/DC and AC/DC electric drives is given as the $2^{\text {nd }}$ curve in Figure 33.

Series-wound DC traction motors described above are widely used in trolley-buses, trams, metro trains, electric trains, and locomotives. In practice, the systems of measuring the parameters of wheel slipping or automatic slip and slide protection systems (ACS) are used in the electric drives of the operating traction locomotives.

A conventional circuit diagram of the slip and slide protection system of DC/DC diesel-electric powered locomotive wheelsets is shown in Figure 35.

\subsubsection{The algorithm of controlling the locomotive's wheelset slipping and sliding}

The slipping parameters of each wheelset may be measured and adjusted by two relays, fixing the slipping process, which are connected between the two armature windings of the traction motor of a bogie. For example, when the slipping of the first bogie's wheelsets proceeds, the difference in the potentials at the points of the winding of the relay $R_{B 1}$ can be observed, and the relay works. In this case, the electric circuit is made by the relay's contacts in the lamp indicating slipping or in the bell. A driver is informed about the proceeding slipping by a light or sound signal. Other relay's contacts open the feeding circuit of the contactor $\mathrm{K}$, thereby interrupting the excitation of the DC traction generator as well as the feeding of the DC traction motors. When the feeding of all traction motors of the operating locomotive is interrupted for a short time, slipping is stopped. The locomotive moving by inertia passes over the section of the greased rails, where the adhesion of the wheelsets to the rails is particularly weak. If slipping continues, the sand is spread in front of the powered wheelset wheels to increase the friction. The main disadvantage of the system is that slipping usually does not stop and the driver has to interrupt the traction mode. This causes the development of the horizontal dynamic forces in the train. These dynamic forces may squeeze out some wagons of the train and cause an accident. The authors suggest to use an automatic drive system of slip and slide protection of the wheelsets in diesel-electric locomotives (of the DC/DC type). The system's circuit diagram is presented in Figure 36.

To control automatically the locomotive's slipping, the load characteristic of the traction generator in the dynamic process should be changed. When any of the locomotive wheelsets starts slipping, the armature current of the traction motors connected in parallel is redistributed, while the voltage at the generator's terminals remains the same (see Figure 35). 


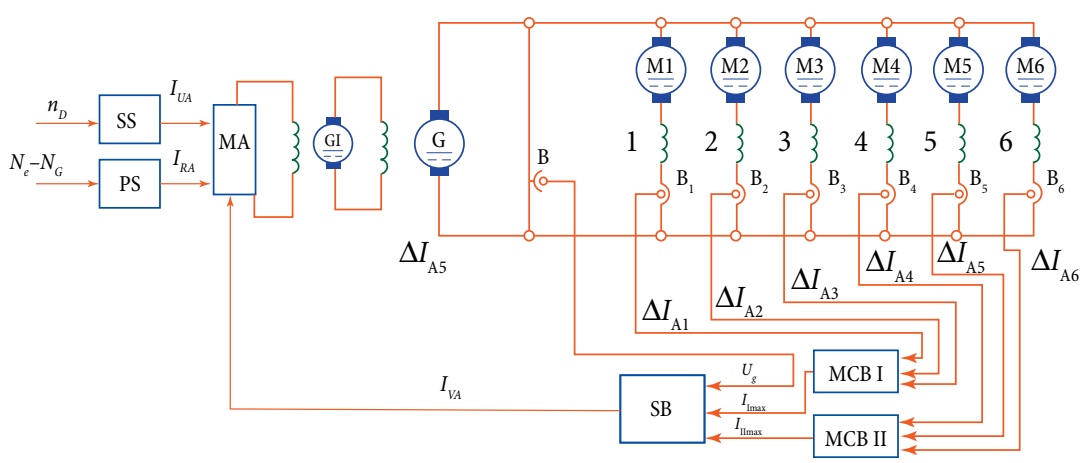

Figure 36. A circuit diagram of automatic control of wheelsets' slip and slide parameters in diesel-electric powered locomotive (of DC/DC type): G is a separately excited shuntwound DC traction generator; G1 is the exciter; MA is a magnetic amplifier; B1,..., B6 are armature current sensors of DC traction motors; $\mathrm{M} 1, . ., \mathrm{M} 6$ are series wound DC traction motors; PS is a diesel power sensor; SS is a diesel speed sensor; MCBI is the maximal current sensor block of traction motors of bogie I; MCBII is the maximal current sensor block of traction motors of bogie II; SB is a selective block; B is traction generator's voltage sensor; $\mathrm{N}_{\mathrm{e}}$ is a signal of diesel motor's power; $\mathrm{N}_{\mathrm{G}}$ is a signal of traction generator's power; $\mathrm{n}_{\mathrm{D}}$ are revolutions (speed) of the diesel engine

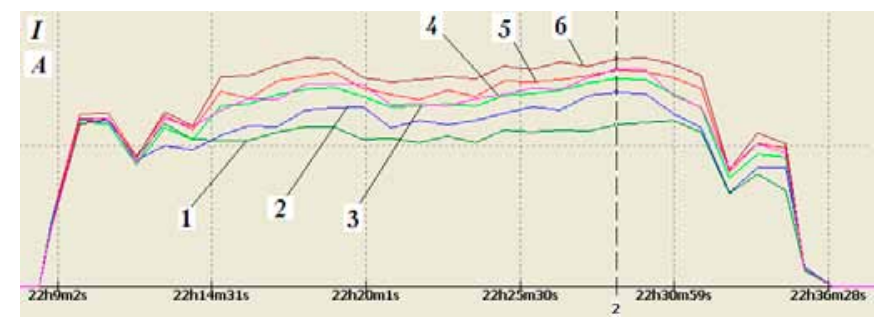

Figure 37. The curves demonstrating the 'spread' in DC traction motors' armature current in the diesel-electric locomotive 2M62M: 1-6 are traction motors' armature currents, measured by a PC in testing trains of various masses

Therefore, the slipping of any wheelset may be determined by measuring the traction motor's armature current by a current sensor (High Precision Drives 2001). A signal for automatic slipping control will be the variation of the traction motor's armature current. The units MCBI and MCBII measure the armature current of all traction motors by the sensors B1-B6 and determine the maximal current. These signals are compared in the pulse gating unit with the signal obtained by the generator's voltage sensor. The load characteristic of the traction generator changed by the maximal current signal is shown with its dynamic component being formed by a green-colored curve (Figure 37). 


\subsubsection{Created algorithm for automatic control of wheelsets' slipping and sliding}

Based on the analysis of the anti-slip systems commonly used in DC/DC locomotives, the authors suggested a new automatic slipping protection system. This system ensures slip and slide monitoring and adjusting of the $\mathrm{ABCD}$ characteristic of the traction generator, when a signal about traction motor's armature current variation is obtained. It also creates a dynamic component of the dynamic characteristic, which is denoted by symbols $E_{1} Y_{1}$ in the first curve of the characteristic and by symbols $E_{2} Y_{2}$ in the second curve of the characteristic (see Fig 36, in green).

The above formation of artificial characteristics of the locomotive, moving at some particular speed in the traction mode, allows us to maintain fixed voltage at the traction generator terminals for a very 'short' time (stabilizing it during the dynamic process), when the wheelsets start slipping. In this case, it is possible to obtain the same speed of rotation of all traction motors' wheelsets and, thereby, to regain proper adhesion of the wheels to the rails. When this is achieved, the previous value of the generator's voltage is automatically regained, i.e., it returns from the line $\mathrm{YE}$ to any $\mathrm{CB}$ portion of the artificial characteristic of the DC generator (Figure 38, in red).

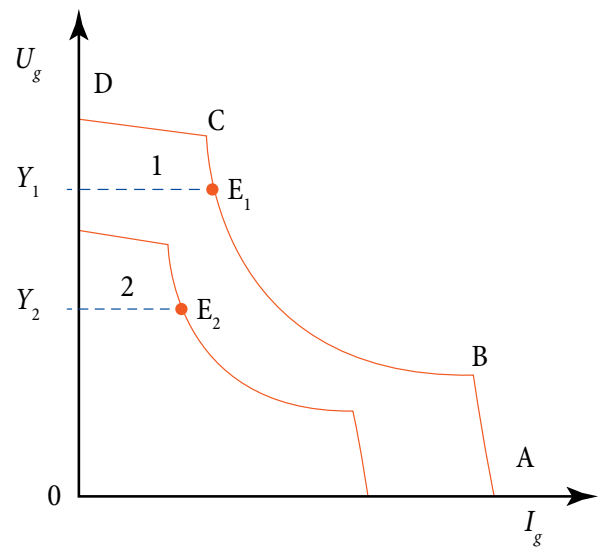

Figure 38. Load characteristics of a diesel-electric powered locomotive's (of DC/

DC type) traction generator $U_{\mathrm{g}}=f\left(I_{\mathrm{g}}\right)$ : red colour denotes conventional characteristics; green shows complementary dynamic characteristics; 1 and 2 show locomotive different drive modes.

The straight-line locomotive's speed does not change during slipping and sliding because the suggested process of the dynamic control of the electric parameters is the fastest control method, since a transient process takes only a few milliseconds. The development of the tractive force of the locomotive is not interrupted because wheelset slipping control is fully automated. 


\subsubsection{Conclusions}

1. Taking into account the specific nature of the conventional characteristic of series excitation DC traction motors, slip and slide protection systems should be used to ensure uniform traction of locomotives.

2. Locomotive slip and slide protection systems, commonly used in the locomotives with series excitation DC motors are not effective because wheelset slipping is controlled by the inertial relay systems. In this case, the development of the tractive force is interrupted during the process, which causes the development of the dynamic longitudinal tensile-compression forces in the train.

3. A locomotive's complementary slip and slide protection system suggested by the authors for the locomotives with series excitation DC traction motors, allows for automatic control of the traction generator's load characteristic, as well as the process of wheelset slipping and sliding without interrupting the development of the tractive force of the locomotive, operating in the traction mode.

4. A locomotive's complementary wheelsets' control system for the DC/DC locomotive allows us to change the nature (type) of traction generators' characteristics for the locomotives operating in the traction mode.

5. Using the locomotive slip and slide protection system created by the authors for the DC/DC locomotive wheelsets, the driver does not have to interrupt the control of the traction mode; therefore, the development of longitudinal forces in the train is avoided.

6. The use of the locomotive slip and slide protection system created by the authors ensures optimal and steady tractive force control.

7. The created locomotive slip and slide protection system ensures the increasing of railway traffic safety and decreasing the of wear/fatigue of the rails and wheelsets as well as the maintenance and repair costs.

\subsection{Rail vehicle passive safety}

\subsubsection{Background}

For defining a framework for the development of the rail vehicle interior passive safety, it is necessary take into account the advances provided by the recent projects (EUCAM, TRACECA, SAFEINTERIORS, etc.) and good practices in the railway industry.

The goal is to considerably reduce injuries and fatalities on railway transport-both passenger and goods (cargo). It is still very significant to identify, formulate, and implement proper means for safety issues in guided railway transport systems. The focus 
in developing of vehicle passive safety means should be devoted to vehicle interior solutions that contribute to the reduction of the severity in terms of occupant injuries.

Train crash events can be basically divided into two phases:

1. The primary collision, where the initial kinetic energy is progressively dissipated by means of plastic structural deformation. In this phase, occupant compartment integrity and acceptable vehicle acceleration levels (crash pulses) are the most important design requirements to be considered.

2. The secondary collision, where the occupant will be subject to a great variety of potentially harmful passenger-interior or passenger-passenger contacts.

\subsubsection{Relevance to the EU-Asia connection}

It is necessary to appraise the requirements and validation procedures and propose references for future standards, recommendations, and regulations to prove the possibilities of survival in the event of catastrophic events in Europe-Asia Railways. At the same time, it is necessary to explore the suitability of the proposed rail vehicle interior passive safety methodologies as applied in the retrofitting of existing rail vehicles, thus contributing to accelerating the improved passive safety levels implementation in the Eurasian railway corridors.

The user-friendliness of the compartment interior is a major design issue and its treatment will complete the framework of railway passive safety. The proposed framework will address design requirements and assess new interior solutions following advanced state-of-art interior designs, representative layouts, a range of suitable crash pulses, and new test and validation procedures suitable for the rail industry. The use of new materials will be fully exploited to improve the occupant-furniture contact characteristics and contribute towards lowering overall vehicle mass levels.

\subsubsection{Related questions needing in-depth research and goals to be achieved}

1. It is necessary to describe the causes of locomotive drive wheel slide and provide measures for the correction and control of slip and slide processes of locomotive wheelsets with AC traction motors.

2. The non-traditional computer-aided slipping and sliding control system of locomotive AC traction motors should be proposed to allow automatic continuous control of electrical parameters of the inverter and traction generator in traction mode (dynamic mode) with the simultaneous slipping process control.

3. It is significant to establish an associated platform for assessing interoperability of all used and future interior rail vehicle layouts, exploited by different railway undertakings in the Euro-Asian land bridge. 
4. It is necessary to identify the passenger key positions in coaches. From such positions, the interior layout of rail vehicle and key types of injury of the rail vehicle passengers seen in the accident data determine trends of passenger (human) kinematics, restraining objects and likely injuries that may be avoided by upgraded passive safety design.

5. It is necessary to identify the most relevant train interior layouts and components with respect to potential hazards, including their design, testing, and concept validation, taking into account the injury assessment of accidents and any potential for improvements with respect to train passengers' inside safety.

6. Guidelines must be established for best practices in Eurasian railways's interior layouts, discussing in depth trade-offs between safety requirements, ergonomics, and non-safety related functionalities. A systematic approach to Professional Risk Manager (PRM) issues will be obtained.

7. There must be new design specifications for interior equipment, furniture and layouts, including requirements for PRM with the aim of achieving cost-efficient, rail vehicle friendly interiors.

\subsection{Railway technical and operational safety}

\subsubsection{Overall description of the problematic}

Compared with all the traffic operating modes in transportation system, railway has the advantage of high efficiency and environmental friendliness, in accordance with the requirements of sustainable development. Also, the railway system plays the role of the main artery in the national economies of countries all over the world. Thus, as a basic requirement for the railway transport, safety is crucial.

The safety of the system is related to two main parts - the equipment, and the operation and organization. The operational part refers to the aspects of technical and operational safety. The technical safety is mainly about the technologies, such as communication technology, computer technology, signal technology, etc. The operational safety is mainly about the coordination of the operation schemes among different sections on the railway corridor, etc.

An intelligence analysis and control system of traffic safety should be created. This system will enable the prevention of railway transport accidents based on the complex analysis of the statistics of transport events. This will eventually increase the level of railway traffic safety. 


\subsubsection{Relevance with the EU-Asia connection}

Safety in the aspects of technology and operation is very important for the rail transport along the EU-Asia connection. It will directly impact the competitiveness of the rail transport and the confidence of the market and governments.

\subsubsection{Related questions needing in-depth research are:}

1) the compatibility of national railway systems relating to EU-Asia connection;

2) operational schemes of EU-Asia connection;

3) technical schemes of railway transportation for EU-Asia connection;

4) evaluation indexes for operational safety of railway transport for EU-Asia connection;

5) evaluation indexes for technical safety of railway transport for EU-Asia connection; and

6) creation of the intelligence analysis and control system of traffic safety.

\subsection{Rolling stock maintenance quality influence on railway safety}

\subsubsection{Overall description}

Railways are made up of complex mechanical and electrical systems and there are hundreds of thousands of moving parts. If a railway service is to be reliable, the equipment must be kept in good working order and regular maintenance is the essential ingredient to achieve this. Rolling stock is the most maintenance-intensive part of the railway system and is the most vulnerable, if maintenance is neglected. A stalled train will block a railway line immediately and will reduce the timetable on an intensively-used system to an unmanageable shamble for the remainder of the day. Reliability is the key to successful railway operation and maintenance should be the number one priority to ensure that reliability is ongoing.

Rolling stock maintenance can be programmed in one of three ways: by mileage, by time, or by condition monitoring. Of these three methods, condition monitoring is the most recent. Traditionally, maintenance was carried out on a time basis, usually related to safety items like braking and wheel conditions. Many railway undertaking administrations later adopted a mileage-based maintenance system, although this is more difficult to operate as one has to keep records of all rail vehicle mileages and this is time-consuming unless they have a modern train control and data gathering system. 
Nowadays, the issue of RAMS (Reliability, Availability, Maintenance, Safety) and issues of safety assessment are used in European countries. Application of certified methodical procedure and methods for application of requirements according to EN 50126, EN 50128, EN 50129 in the railway system seems to be the right way to achieve this.

Rolling stock performance in respect of failures can be measured by MTBF (Mean Time Between Failures) or MDBF (Mean Distance Between Failures). It is sometimes measured by numbers of failures per year, month or week, but this may not represent an accurate rate consistent with mileage. On the other hand, rolling stock does deteriorate rapidly in storage and this, in itself, produces failures, although these may not be the same failures seen under normal service conditions.

Research efforts in the Rolling Stock Equipment and Components Program area of the US Department of Transportation focus on the development and improvement of equipment defect detection and control. Both wayside and on-board detection and control systems offer diverse platforms for such research and demonstration. Early defect detection greatly reduces the likelihood of equipment failure and helps prevent derailments. This program area is strongly oriented toward a proactive approach to preventing derailments, equipment failure, and undesired emergency brake applications. Risk assessment and mitigation, along with support for safety assurance are also integral elements (Safety Assurance Guidance RSSB ... 2013). The Rolling Stock and Components program seeks to fulfil the demands of faster, heavier, and longer trains by extending equipment and material life through early defect detection and advanced material development.

\subsubsection{Relevance with EU-Asia connection-Wagon Maintenance in European Rail Network}

The International Union of Private Wagons (UIP) encompasses 16 European associations from 16 European Countries. The associations and the UIP represent owners, loaders, users, and other parties interested in about 180,000 private rail freight wagons running in Europe. The UIP's main objective is to guarantee a future for the private wagon within a liberalized rail freight sector. Within the framework of its European activities, UIP actively supports all corresponding European liberalization policy endeavors, together with its partner organizations.

According to UIP's session on "Safety at the level of vehicles" at the Safety Conference in Brussels in 2009, four systems influence the safety of a freight wagon and each system consists of various building blocks (see Figure 39), one of them being the maintenance system. 

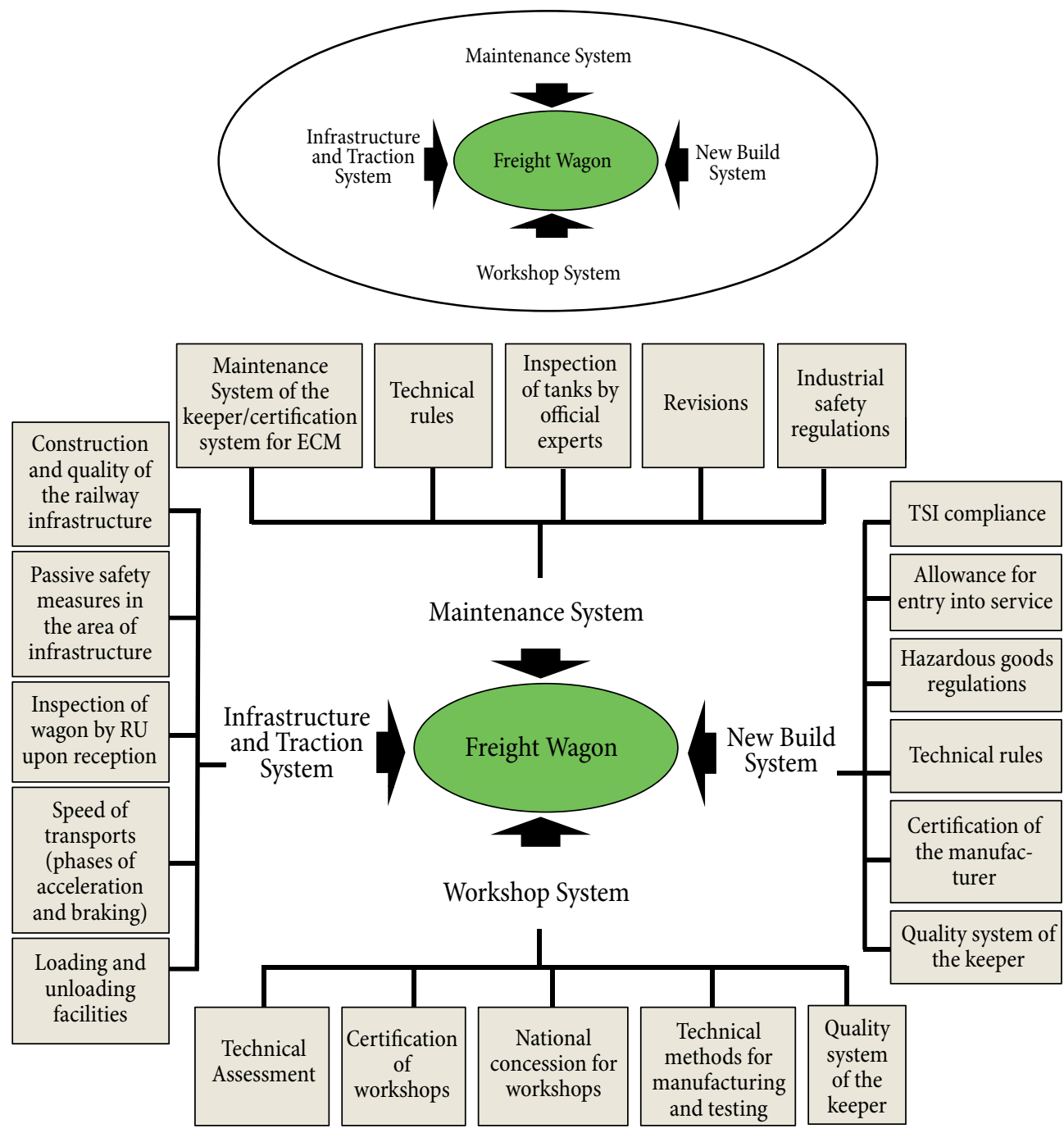

Figure 39. Maintenance Influence on the safety of freight wagon [scheme] (http://ec.europa.eu/transport/modes/rail/events/doc/ppt_presentations/uip_eu_ sicherheitskonferenz.pdf)

One of the main drivers of safety in the life cycle of a wagon is the maintenance system which can be based on maintenance regulations of UIC railways, and improved on the basis of failures detected in daily business; attempts should be made to get more standardization in order to prevent mistakes in workshops. 


\subsection{Investigation on improving diesel-electric locomotives' maintenance system}

\section{Background}

An analysis of failures of the diesel-electric locomotive's units and parts is presented. The reliability indicators of these parts were determined according to the locomotive run. Numerical and distribution functions describing mileage (run) of the locomotives between overhauls were also defined. The dependence of the flow of failures on mileage distribution between overhauls was determined and the optimal mileage was calculated. Methods of determining mileage based on parametric and non-parametric reliability are presented. These methods help to reduce maintenance and repair costs as well as the idle time of locomotives. They also help to increase reliability. The suggested methods were used in calculating optimal mileage (run) for the locomotives of the company LG. The efficient use of traction rolling stock helps to increase the efficiency of transportation and save time, materials, financial resources, etc. Therefore, new ways and methods of increasing the efficiency of rolling stock maintenance and operation should be sought. It is well known that reliability is the main factor determining effective rolling stock operation. We know by experience that the effective use of locomotives is based on the system of scheduled repairs and preventive maintenance, because timely repairs and maintenance can ensure reliable rolling stock operation.

Now, the efficiency of rolling stock operation is usually assessed by average (mean) values. This method is well-suited to our case because operating conditions of locomotives are similar all over the country. The main problem is to determine properly the distance run between overhauls which would help decrease the volume as well as labor input (man / hours) and costs of repairs. This is particularly important for a joint-stock company like LG, because so far factory repairs of locomotives have been done abroad and their costs, but not quality, have been constantly growing (Cantos et al. 2000; Локомотивы ... 1997).

A feasibility study was carried out, that was aimed at providing sound grounds to repairs currently performed in the depot according to the specified distance run between overhauls.

\subsubsection{Locomotive deterioration analysis}

The control parameter of a deteriorating part is a continuous random variable. The law of its distribution can be described in terms of distribution density of the parameter. The distribution law is chosen taking into account the analysis of physical processes taking place when parts and units are aging or deteriorating. The serviceability of the 
parts is determined based on the control parameter chosen. The types of distribution commonly used to sufficiently accurately describe random variables and serviceability of technical devices include normal, exponential, logarithmic, and Weibull distribution.

Theoretical and practical analysis (Галкин et al. 1981) shows that random variables of the control parameters for the fixed run can be adequately described by normal distribution law.

If a random variable is affected by a large number of equally important random factors, then, the distribution of such variables complies with the normal distribution law.

The deterioration of the locomotive parts depends on many random factors, such as the material of which the part is made and its chemical composition; the physical properties and quality of the manufactured part; strength characteristics, climatic conditions of the locomotive operation (e.g. temperature, atmospheric pressure, air humidity, and dust content; loading modes and their rate, number of starting and braking operations); the time of maximum loading; contamination of rubbing surfaces with abrasive materials (e.g. sand sprinkled between the drive wheels and the rails); the condition of the railroad on which the loading on the locomotive and its intensity depend, and many other factors. It is hardly possible to determine which of the above factors is most important for the process of deterioration of the parts. Under particular conditions, these factors can have actually the same influence on the deterioration of the parts; therefore, the values of the control parameters follow the normal distribution law for the case of fixed mileage. The distribution density will be described as follows:

$$
f(x)=\frac{1}{\sigma_{x} \sqrt{2 \pi}} \cdot e^{\frac{\left(x-m_{x}\right)^{2}}{2 \sigma_{x}^{2}}} ;
$$

where: $m_{x}$ is mathematical expectation of the control parameter; $\sigma_{x}$ is mean square deviation of the control parameter; and $x$ is the control parameter variable.

The total number of control parameters obtained for the parts with a short operating period after repair can be adequately described by a part of the normal distribution law.

\subsubsection{Calculation of the numerical characteristics and distribution functions of mileage between repairs}

For predicting the service life or deterioration rate of the considered parts and units, the analytical relationship between the numerical characteristics $m_{x}$ and $\sigma_{x}$ and mileage should be established. In general, this relationship may be considered as a non-linear function $\mathrm{y}=\left(a_{1}, a_{2}, \ldots, a_{s}, l_{i}\right)$ of one $l_{i}$ argument including $S$ parameters $a_{1}, a_{2}, \ldots, a_{s}$. This function can be approximated by the empirical regression presented in the form of the points $\left(l_{i}, y_{i}\right) i=1,2,3, \ldots, n$. Here, $y$ is assumed to be a parameter of the considered distribution law. 
The analysis of the major distribution laws shows that the characteristics of normal, exponential and gamma distribution can be expressed by mathematical expectation of a random value and variance, which, in turn, are the parameters of the normal distribution law.

The parameters of the function $y$ are calculated by the least square method, the conditions of which are expressed as:

$$
Z\left(a_{1}{ }^{-} \bar{a}^{-\cdots-a_{s}}\right)=\sum_{i=1}^{n}\left[\begin{array}{lll}
f\left(a_{1} a_{2}\right. & \left.a_{s} l_{i}\right)-y_{i}
\end{array}\right]^{2} \rightarrow .
$$

The minimum value of the function can be determined by the method of gradients. The calculation is made by generating a recurrent sequence of values $a_{1 k}, a_{2 k}, \ldots, a_{s k}$. This method allows the empirical data to be approximated by any type of relationship. The most suitable relationship criterion is the minimum of residual variance:

$$
D_{e}=\frac{l}{n-S-l} \sum_{i=1}^{n}\left[y_{i}-f\left(a_{1}, a_{2}, \ldots, a_{s}, l_{i}\right)\right]^{2} .
$$

Suppose, that when approximating the empirical relationship $f_{l}(l)$ with $S_{1}$ parameters, the residual variance is equal to $D_{01}$. To check up the decrease of variance, while approximating empirical data of another relationship $f_{2}(l)$ expressed by $S_{2}$ parameters, the hypothesis $H_{0}: D_{01}=D_{02}$ is made. Testing of this hypothesis makes sense if $D_{01}>D_{02}$, and it is performed based on Fisher's criterion (Галкин et al. 1981):

$$
\hat{F}=\frac{D_{01}}{D_{02}}
$$

The relationships describing the deteriorating parts $m_{x}(l)$ and $\sigma_{x}(l)$ are adequately approximated by linear functions. As shown by theoretical and practical studies (Галкин et al. 1981), the relationships describing the wearing of the parts usually follow the linearity law. Therefore, the values of the numerical characteristics $m_{x}(l)$ and $\sigma_{x}(l)$ are adequately approximated by linear functions:

$$
y=a_{x}+b
$$

In this case, the conditions of least square difference will be as follows:

$$
\sum_{i=1}^{n}\left[y_{i}-\left(a l_{i}+b\right)\right]^{2} \rightarrow \min
$$

where: $y_{i}\left\{\begin{array}{l}m_{x}, \text { when approximating } m(l) \\ \sigma_{x} \text {, when approximating } \sigma(l)\end{array}\right.$. 
Linear function coefficient $a$, based on least square difference, will be expressed in the following way:

$$
a=r_{y l} \frac{\sigma_{y}}{\sigma_{l}}
$$

where: $r_{y l}$ is correlation coefficient relating to random values $y$ and $l ; \sigma_{y}, \sigma_{l}$ is mean square deviation of $y$ and $l$, respectively

$$
\sigma_{l}=\sqrt{\frac{l}{N-l}} \sum_{1}^{N}\left(l_{i}-m_{l}\right)^{2}
$$

where: $m_{l}=\frac{1}{N} \sum_{1}^{N} l_{i}$ is average mileage; $\quad m_{y}=\frac{1}{N} \sum_{1}^{N} y_{i}$ is mean value of $y$.

Regression equation coefficient $b$ is as follows:

$$
b=m_{y}-a m_{l} .
$$

The correlation coefficient $\sigma_{y l}$ characterizes density of linear relationship between the random values $y$ and $l$ :

$$
\sigma_{y l}=\frac{K_{y l}}{\sigma_{y} \sigma_{l}}=\frac{a_{u}\left(y_{1} l\right)-m_{y} m_{l}}{\sigma_{y} \sigma_{l}},
$$
where: $a_{u}\left(y_{1} l\right)=\frac{1}{N} \sum_{1}^{N} l_{i} b_{i}$ is the moment of the second product of the random values
$y$ and $l$.

\subsubsection{Calculation of confidence values}

To predict deterioration, the relationships $m(l)$ and $s(l)$ are extrapolated to the area of great mileage (run), under the condition that the deterioration of the parts is within the limits of normal operation. This can be achieved by properly choosing the allowable deterioration degree of the part analyzed.

Then, by substituting the mileage value $l$ into the expressions (Formulae 21 and 23 ), we can calculate the numerical values of $m(l)$ and $s(l)$ and plot distribution density curves. When the mileage (run) $l$ increases, the probability that the control parameter value will exceed the specified limit also increases. This will be considered as the failure of the part due to deterioration.

Thus, when the mileage $l$ increases, the probability of the part failure $Q$ also increases, while probability of break-free operation of the part $P$ decreases correspondingly. 
The mileage (run), at which the probability of break-free operation of the part is equal to the fixed value $\mathrm{g}=(1-\mathrm{Q}) \cdot 100 \%$, is referred to as gamma-percentage mileage (run) between repairs.

The value of the distribution function, when the mileage function value $l$ is fixed, will be obtained in the following way:

$$
F(l)=\int_{x_{\text {nom }}}^{x_{\text {lei }}} f(x) d x,
$$

where: $x_{\text {nom }}$ is the nominal value of the control parameter.

When the control parameter (e.g. wheelset deterioration) value is constantly increasing under the normal distribution law, breakage probability for a particular mileage $l$ can be calculated in the following way:

$$
F(l)=\frac{1}{\sigma_{x}(l) \sqrt{2 \pi}} \int_{x_{l e i}}^{m_{x}+3 \sigma_{x}} \exp \left\{-\frac{\left[x-m_{x}(l)^{2}\right]}{2 \sigma_{x}^{2}(l)}\right\} d x .
$$

If the control parameter value decreases when $l$ is increased (e.g. wheelset thickness), the probability of failure is determined as follows:

$$
F(l)=\frac{1}{\sigma_{x}(l) \sqrt{2 \pi}} \int_{m_{x}-3 \sigma_{x}}^{x_{l e i}} \operatorname{esp}\left\{-\frac{\left[x-m_{x}(l)\right]^{2}}{2 \sigma_{x}^{2}(l)}\right\} d x .
$$

The integral of the Formulae (25) and (26) cannot be expressed by elementary functions; therefore, it is determined by numerical methods. Given the function of mileage distribution of a deteriorating part, distribution density is found as the first derivative of the function:

$$
f(z) F^{\prime}(l) .
$$

Statistical density distribution is described by the relationship:

$$
f(l)=\frac{F\left(L_{i+1}\right)-F\left(L_{i}\right)}{\Delta L} .
$$

The main parameters of the repaired unit (part) reliability are interrelated by the integral equation as follows:

$$
w(l)=f(l)+\int_{o}^{l} w(\tau) f(l-\tau) d \tau .
$$


Under the law of random value normal distribution, the analytical solution of the above integral equation is possible:

$$
w(l)=\sum_{i=1}^{\infty}\left[\frac{1}{\sigma \sqrt{2 \pi \cdot i}}\right] \exp \left[-(1-i m)^{2} / 2 \sigma^{2} i\right] ;
$$

where: $m$ and $s$ are mathematical expectation and mean square deviation (mileage before failure) of the random value, respectively; $l$ is mileage; $i$ is the number of failures (from the beginning of observation).

\subsubsection{Determining reliability indicators (criteria) based on the distance run between failures}

The control parameters' values of the locomotive units and parts allowing us to determine and predict their performance cannot be measured. However, the interval between scheduled repairs should be determined for these units. This interval should be such that, if exceeded, the intensity of failures will considerably increase.

The solution to these problems based on the failure flow variation would allow us to predict the increase of failure rate with the growth of the locomotive mileage and to make a decision about the need for a scheduled repair.

Applying the system of scheduled preventive maintenance and repairs actually means longevity (durability) test of the parts and units ( $N, M$ and $L)$ of a locomotive, when the parts of a particular type $N$ are observed (tested) for a particular period (mileage) $L$. The obtained mileage in the period between overhauls $L_{i}$ is a random value because it can deviate from the specified value by $\pm 10 \%$. When the mileage increases, the locomotive (or its unit) sent for a scheduled repair will not be observed in operation from the beginning of observation. Thus, the number of the locomotives $N(t)$ selected for testing (observation) is the mileage function, while their testing plan will be as follows:

$$
\left[N, M, L_{1}, L_{2}, L_{3}, \ldots, L_{i}, \ldots, L_{N}\right] \text {. }
$$

Assume that the $i$-th item of the part $M_{i}$ will fail in the observation period $L_{i}$, when the mileage is $l_{1 i}, l_{2 i}, \ldots, l_{m i}$ respectively.

Given the information about the failures during the operation, an empirical function can be generated in the absence of data on the applicable law of failure distribution and its numerical characteristics.

The distribution is calculated by using a reconditioning function:

$$
\hat{F}(l)=\left[\sum_{i=1}^{N(l)} n_{i, l}\left(L_{i}\right) / m_{i}, L_{i}\right] / N(l) ;
$$

where: $n_{i, l}\left(L_{i}\right)$ is the number of the $i$-th item reconditioning (repairs) of the observed part at the mileage $L ; i=1,2,3, \ldots, N(l) ; \mathrm{m}_{i}, L_{i}$ denote the total reconditioning (repairs) number of the $i$-th item in the period $L_{i}$. 
Parts and units can work without failure over the whole observation period. In this case, $n_{i, l}\left(L_{i}\right) / M_{i}, L_{i}=0$. By differentiating the empirical distribution function, distribution density functions in the period between failures are calculated:

$$
\hat{f}(l)=\left[\begin{array}{c}
\wedge \\
F(l+\Delta l)-\hat{F(l)}
\end{array}\right] / \Delta l .
$$

The parameter of the flow of failures $w(l)$ is related to the mileage (run) density distribution between failures $f(l)$ by the integral equation (16). The analysis of this process shows that the information about the mileage of the unit operation between failures is discontinued on the left side and broken several times on the right side. On the lefthand side, it can be accounted for by the lack of information about the unit failure in the time from the beginning of its consideration to the beginning of its observation. On the right-hand side, the reason is a scheduled repair of the locomotive or writing it off (then, the observation is discontinued). Therefore, reconditioning of each item over a short observation period will not be expressed completely, but rather its particular part will be shown because, at the beginning of the considered period, units (parts) will have different service life (run). By superimposing their reconditioning processes one over another, we will get a generalized reconditioning process characterizing the whole observation period between scheduled repairs.

If the park of locomotives in operation is rather large ( $>100$ items.), a representative sample for determining their reliability and, consequently, reliable indicator of their failure-free operation can be obtained over short observation periods. This may be achieved based on the parameter of the failure flow, calculated by grouping the data on mileage between failures:

$$
\hat{w}(l)=\Delta m / \sum_{i=1}^{N(l)} \Delta l_{i} ;
$$

where: $\Delta m$ is the number of mechanism failures in the interval $\Delta l ; N(l)$ is the number of the observed aggregates in the interval $\Delta l ; \Delta l_{i}$ is the $i$-th aggregate mileage in the interval $\Delta l\left(\Delta l_{i} \leq \Delta l\right)$.

To determine the number of unit failures in the total mileage grouping intervals, the data on reconditioning of the same type of units (parts) should be provided in terms of run in the considered period between overhauls.

For this purpose, the previous repair moments, which are the starting points of counting the mileage of a particular unit, are conjugated. When the information is provided in this form and the time between overhauls is divided into the intervals, the total mileage of a unit and its failures in every interval are determined. This, in turn, allows us to calculate and draw the failure flow parameter diagram. At the same time, 
grouping of data may considerably decrease the reliability of the obtained indicators compared to those obtained for directly calculated distribution functions of the mileage before failure. The shift of the values of the failure-free operation indicators will be much greater, when the amount of statistical data is small, and this is typical of highly reliable units.

The empirical failure function can be calculated based on the data collected over short periods of observing the operation of the unit, when the labor input (mileage) at a particular moment of time is different for different units (locomotives) from the beginning of the period analyzed:

$$
\hat{F}(l)=\left[\sum_{i=1}^{N(l)} n_{i, l}\left(L_{i}\right) / m_{i, l}\right] / N(l),
$$

where: $L_{i}$ is the period of collecting the information about the mileage until the $i$-th unit failure.

$$
\mathrm{Li}=\left\{\begin{array}{l}
L_{i}-l_{p r i} \text { when } l_{p r i}>0 ; l_{p i}=L_{i} ; \\
l_{p i} \text { when } l_{p r i}=0 ; l_{p i} \leq L_{i} ; \\
l_{p i}-l_{p r i} \text { when } l_{p r i}>0 ; \quad l_{p i}<L_{i}
\end{array}\right.
$$

where: $l_{p r i}$ is labor input (mileage) at the beginning of observation; $l_{p i}$ is labor input (mileage) at the end of observation.

By classifying the data in this way, the information about unit reliability is most effectively used for calculating the distribution function because the data are not grouped. The data on failures obtained in long-term observation may be used for analyzing reliability indicators over long operation periods.

By solving the integral equation, the dependence on the parameter of flow of failures may be calculated based on empirical distribution functions. The parameter of flow of failures can also be calculated by grouping the failures in the mileage intervals, e.g. $\Delta l=50,000 \mathrm{~km}$. The parameters of flow of failures calculated in two ways show satisfactory agreement.

\subsubsection{Calculating the optimal mileage between locomotive repairs}

To avoid locomotive failures due to deterioration of its parts, a system of scheduledpreventive repairs is used. According to it, parts and units should be either reconditioned or replaced if operational parameters approach the admissible limiting values. A scheduled repair should be performed when the mileage $L$ is such that the number of failures expressed by the increase of the failure flow parameter $m_{1}$ will be larger than the number of failures $m_{2}$ in running over the same period. 
To optimize the mileage between repairs as an efficiency function, the parameter of flow of failures as a function of failure-free operation indicator can be used:

$$
g(l)=\frac{1}{L}\left[C_{n} \int_{o}^{L} w(l) d l+C_{p}\right] .
$$

Optimal mileage between repairs largely depends on the relationship between the costs of scheduled $\left(C_{p}\right)$ and unscheduled $\left(C_{n}\right)$ repairs. The costs of scheduled repairs $\left(C_{p}\right)$ consist of the costs of materials or spare parts $\left(C_{1}\right)$ as well as the costs of labor $\left(C_{2}\right)$ and losses due to the locomotive idle time $\left(C_{3}\right)$ :

$$
C_{p}=C_{1}+C_{2}+C_{3} \text {. }
$$

The costs of unscheduled repairs, beside the above costs $\left(C_{1}, C_{2}, C_{3}\right)$, also include losses $C_{4}$, caused by the locomotive failure on the route, i.e.,

$$
C_{n}=C_{1}+C_{2}+C_{3}+C_{4} \text {. }
$$

Then, $C_{n}{ }^{3} C_{p}$, Moreover, $C_{n}=C_{p}$ only for the elements which, when broken, do not cause the delay of the locomotive on the route.

As far as we know, there are no accurate methods of calculating losses brought about by stopping the train now if the locomotive failed between stations. If such methods could be found, they would not properly assess the losses caused by failure $C_{4}$.

However, by using the relative values of $C_{n}$ and $C_{p}$, we can determine the mileage between the scheduled repairs $L$, to which minimum total costs $g\left(L_{o}\right)$, i.e. optimal mileage between repairs correspond.

Let us note that:

$K=C_{n} / C_{p}$

Since $C_{n}{ }^{3} C_{p}$, then $K \geq 1$

By expressing $C_{n}$ as $K$ and $C_{p}$ and substituting (22), we will get:

$$
g(L)=C_{p}\left[K \int_{0}^{L} w(l) d l+l\right] / L .
$$

According to physical meaning, the numerator of the fraction (26) represents the total costs of scheduled and unscheduled repairs. Therefore, the expression in brackets is the total number of the repairs compared, i.e., the value of sets of the total number of unscheduled repairs $\int_{0}^{L} w(l) d l$ equal to the number of scheduled repairs equivalent to it $\operatorname{costs} K \int_{0}^{L} w(l) d l$. 
The relationship

$$
S(L)=\left[K \int_{0}^{L} w(l) d l+l\right] / L .
$$

is the total relative number of repairs calculated for the unit mileage.

\subsubsection{Determining the mileage based on parametric and non-parametric reliability}

The repair of some units and parts of locomotives should be performed because the limiting value of the control parameter is reached in the aging element or for other reasons unconnected with the process of deterioration. For example, wheelset tires can be changed because of deterioration, or if the fit of wheelset tire has is not as tight or firm as it should be.

It is evident that while determining the intervals between repairs for the parts which may have failures of $m$ types, requiring the same operations for their reconditioning or repair, all the failures should be taken into consideration. The probability of failure-free operation of the unit (part) in this case is determined as the probability of a complicated event, implying that none of $m$ type failures will take place in the considered period of the run:

$$
P_{\Sigma}(l)=\prod_{i=1}^{m} P_{i}(l) ;
$$

where: $P_{i}(l)$ is the probability that $i$-th type failure will not take place during the run 1 (probability of $i$-th type failure-free operation); $m$ is the number of failures, requiring the same repair or reconditioning operations.

The analysis of the data on the locomotive wheelset tire mileage before failure shows that, when the mileage increases after ER-3 (KR), the value of failure flow parameter also increases because of the wheelset tire loosening. It means that with the deterioration of the wheelset tire the number of non-parametric failures also increases. In the case of wheelset tires, it can be explained by a decrease in their thickness and mass due to deterioration, leading to heating up of wheelset tires in braking, which facilitates slippage and, therefore, increases the rate of non-parametric failures.

Thus, locomotives can experience two types of failures in operation:

1) parametric failures, caused by deterioration of the locomotive parts, when the control parameters exceed the specified limits;

2) non-parametric failures, including loosening of the fix, breaking, etc; these failures cannot be avoided in operating conditions, but their rate depends on the deterioration level of a part or unit. 
The above failures have some common features as follows: each part (or unit) has a control parameter which is randomly changing in operating conditions and is a function of labor input (mileage). When the parameter varies within the specified limits, no parametric failure occurs. However, the increase (or decrease) of the parameter increases the probability of non-parametric failure occurrence. Failure is characterized by a sudden change in the condition of a part or unit. In this case, probability of failure-free operation may be expressed in the following way:

$$
P_{\Sigma}(l)=P_{p}(l) \cdot F_{n}(l),
$$

where: $P_{p}(l)=1-F_{p}(l)$ is probability to avoid gradual failure of the part during the run (labor input);

$F_{p}(l)$ is distribution function of mileage (run);

$P_{n}(l)=1-F_{n}(l)$ is probability to avoid non-parametric failure during the run (labor input); and

$F_{n}(l)$ is distribution function of labor input (run) until failure occurs.

Based on the total probability of failure-free operation, distribution function $P_{\mathfrak{a}}(l)$ of mileage between failures is determined, taking into account parametric and nonparametric reliability of a unit (part). Then, in the course of numerical differentiation (28) with respect to $F_{\mathfrak{a}}(l)$, the respective density function $f_{\mathfrak{a}}(l)$ is calculated. By solving the integral equation (29) from $f_{\mathfrak{a}}(l)$, the dependence of flow of failures on labor input (run) $w_{\grave{a}}(l)$, which enters the efficiency function (39), is determined.

The admissible deterioration level of a part depends on the quality of repair and operating conditions. For example, the admissible deterioration level of wheelset tires should be such that they could be replaced when the mileage (run) allows for slightly higher probability of parametric rather than non-parametric failures, or the probability of both is the same.

These methods were used for developing a rational mileage structure for Lithuanian Railways locomotives' operation between overhauls, taking into account their operational conditions. Based on the current flows of failures and run between overhauls, optimal maintenance and repair volume at minimal cost was determined.

\subsubsection{Discussion}

Deterioration rate of locomotives largely depends on operating conditions in Eurasian railway corridor location. The appropriate classification and processing of the data obtained in the period of diesel locomotive operation allows us to get reliable criteria of failure-free operation, to assess the effectiveness of measures aimed at achieving higher reliability, and to determine optimal time of scheduled-preventive repairs and locomotives mileage. Solving the problem of optimizing mileage between overhauls, the repair 
costs of parts and units of diesel locomotives should be determined. To obtain more precise and reliable results, further research should be made according to a complex program, providing for investigation of intensity of diesel-electric locomotive deterioration as well as geometric railway bed parameters.

\subsection{Modelling of constant inter-failures of renewed passenger multi-units fleet}

\subsubsection{Background}

While railway companies operate rolling stock, a substantial part of its expenses goes to maintenance and repair. However, the amount of repair works is directly proportional to the average age of a rolling stock fleet or its reliability. When renewal of an existing fleet of a few dozen rolling stocks, the installation of the new vehicles reduces the overall failure amount of the fleet proportionally to the number of acquired vehicles. The authors provide a concept for creating the model of a passenger rolling stock's failure intensity according to the mileage. According to this model, a vehicle fleet renewal algorithm can be created and used in order to limit the fluctuation of the fleet's average failure intensity as much as possible and to achieve the most accurate correlation between the number of failures and the fleet's average mileage. Thus a railway company has an opportunity to avoid unplanned expenses for repairing the vehicles during the unforeseen failure peaks. The SPLINE method is proposed in order to indicate the vehicle failure flow's dependency on the vehicle mileage. After using this method to indicate the variation of the fleet's constant inter-failure according to the mileage, the fleet's failure intensity can be modeled according to the algorithm of installing the acquired vehicles for operation.

\subsubsection{Relevance}

Railways are made up of a huge complex of mechanical and electrical systems, which consist of thousands moving parts. If a railway service is to be reliable, the equipment must be kept in good working order and regular maintenance (repair) is the essential ingredient to achieve this. Rolling stocks are the most intensively exploited segment of the railway system and they are the most vulnerable if maintenance is neglected. A stalled train will block a railway line immediately and will reduce a timetable on an intensivelyused system to an uncontrollable shamble for the remainder of the day. Reliability is the key to successful railway operation and maintenance should be the number one priority to ensure that reliability is ongoing. Lithuanian and many scientists worldwide carry out 
comprehensive research works to ensure both the technically and economical effective maintenance system of rolling stock in railway companies (Bureika 2011; Cheng et al. 2010; Gelumbickas and Vaičiūnas 2011; Vaičiūnas and Lingaitis 2008, Kabo and Ekber 2005, Karlaftis and Sinha 1997). On the other hand, Swedish scientists assessed the most popular maintenance approaches, i. e., strategies, policies, or philosophies, using a fuzzy multiple criteria decision making (MCDM) evaluation methodology (Al-Najjara et al. 2003). The fuzzy AHP method proposed is a simple and effective tool for tackling the uncertainty and imprecision associated with MCDM problems, which might prove beneficial for plant maintenance managers to define the optimum maintenance strategy for each piece of equipment (Sivilevičius et al. 2010; Wang et al. 2007).

Rolling stock maintenance can be programmed in one of three ways: by mileage, by time, and by condition monitoring (Cherry 2005; Kazopoulo et al. 2007). Of these three methods, condition monitoring is the most recent (Falco et al. 2013). Many railway undertaking administrations adopted a mileage based maintenance system, although this is more difficult to operate as one has to keep records of all rail vehicle mileages and this is time-consuming unless they have a modern train control and data gathering system (Wang et al. 2007). The maintenance of rail vehicle can be characterized into two types: corrective maintenance and preventive maintenance. The time intervals at which preventive maintenance is scheduled are dependent on both the life distribution of the components and the total cost involved in the maintenance activity, but corrective maintenance cannot be avoided when component failure component occurs. The total cost of rolling stock maintenance depends on the percentages in performing preventive maintenance and corrective maintenance. In general, more frequent preventative maintenance drives up the total maintenance costs for rolling stock. On the other hand, proper preventative maintenance can potentially reduce the risks associated with rolling stock mechanical failure. Thus, railway operators are constantly left weighing the safety risks against the maintenance costs. Railway safety is defined as the most crucial factor for the selection of a rolling stock maintenance strategy (Cheng and Tsao 2010).

Researchers Wang and Chen evaluated four maintenance strategies (such as corrective maintenance, time-based preventive maintenance, condition-based maintenance, and predictive maintenance) for different equipment (Wang et al. 2007). In order to avoid the fuzzy priority calculation and fuzzy ranking procedures in the traditional fuzzy AHP methods, a new fuzzy prioritization method was proposed. This fuzzy prioritization method can derive crisp priorities from a consistent or inconsistent fuzzy judgment matrix by solving an optimization problem with non-linear constraints. Iranian scientists examined a new approach for selecting optimum maintenance strategy using qualitative and quantitative data through interaction with the maintenance experts (Bashiri et al.2011). This approach has been based on linear assignment method 
(LAM) with some modifications to develop interactive fuzzy linear assignment method (IFLAM). The proposed approach is an interactive method which uses qualitative and quantitative data to rank the maintenance strategies.

In contrast to maintenance strategy selection in the manufacturing industry, the maintenance of rolling stock impacts also both traffic safety and passenger comfort (Sun and Li 2010). Because preventative maintenance and corrective maintenance affect these three factors (safety, comfort, and cost), railway system operators must establish a maintenance strategy that strives for an optimum balance. Given this, a method that defines a proper rolling stock maintenance strategy is invaluable to system operators (railway companies), system safety supervisors (governments), and system customers (passengers). Iranian researchers proposed to apply the fuzzy Delphi method in Simple Additive Weighting (SAW) for solving the maintenance strategy selection problem (Jafari et al. 2008).

Rolling stock performance in respect of failures can be measured by MTBF (Mean Time Between Failures) or MDBF (Mean Distance Between Failures). It is sometimes measured by numbers of failures per year, month, or week, but this may not represent an accurate rate consistent with mileage (Sawicki and Zak 2009). On the other hand, rolling stock does deteriorate rapidly in storage and this, in itself, produces failures, although these may not be the same failures seen under normal service conditions. Scientists Falco et al. (2013) described three case studies for existing rolling stock, mid-life overhaul, and new build rolling stock.

Chinese researchers proposed to permit an approach for selecting a maintenance strategy for rolling stock and obtaining possible spare parts' quantities and replacement intervals for the components of rolling stock. The methodology adopts an analytic network process (ANP) technique for the strategy evaluation, because ANP considers the important interactions among evaluation factors. Two Greek researchers introduced a reliability modeling and analysis framework based upon the distinct class of non-stationary Functional Series (FS) models (Stavropoulos and Fassois 2000). The FS framework was applied for the modeling and analysis of two rail vehicle reliability series named as Times Between Failures (TBFs). Two models, one based on fuzzy logic (FL) and the other on artificial neural networks (ANN), were developed by Wang to predict the vehicle breakdown duration (Wang et al. 2005).

In order to improve the rolling stock's maintenance system, it is favorable when the number of failures is proportional to the vehicle mileage or moto-hours. Then the number of failures can be predicted according to the mileage prognosis. The future needs of works and spare parts can be foreseen according to the prognosis for the number of failures. As seen from experience, the number of rolling stock's failures is not always proportional to the mileage. Due to the rolling stock's maintenance, the 
number of its failures pulsates. Since each rail vehicle is a unique product, the repair of each vehicle is somewhat distinctive, and it is impossible to foresee every potential work or complication. Therefore, after the repair, the amount of failures increases for some time. This is the main reason for the pulsation of the number of failures. Each newly-installed vehicle has its own influence on the overall pulsation of the number (as well as the intensity) of the fleet's failures. This means that the pulsation of the overall number and intensity of the rolling stock's failures depends on the fleet renewal algorithm. If renewing an existing fleet with a few dozen vehicles, the acquisition of the new vehicles reduces the overall failure amount of the fleet proportionally to the number of acquired vehicles. However, for a newly formed fleet, a different consistent pattern applies which is necessary to be studied. When researching the consistent pattern of a renewal vehicle fleet, a model concept for the change of passenger rolling stock's inter-failure according to the mileage has been formed. In accordance with this model, a fleet renewal algorithm is planned to be created in the future in order to limit the fluctuation of the fleet's average failure intensity as much as possible (by limiting the sinusoid amplitudes) and to achieve the most accurate correlation between the failure intensity and the fleet's average mileage. In order to reach this goal, the Lithuanian rail vehicle reliability researches were performed according to the vehicle types: electric multi-unit reliability research, and diesel multi-unit reliability research. According to the results of these researches, a mathematical model of the renewal rolling stock fleet's failures was created. One of the peculiarities of this methodology is that the failure flow's dependency on the vehicle mileage is proposed to be indicated using the SPLINE method (Lyche and Morken 2008).

\subsubsection{Technical context and methodology}

Indicators of the rolling stock interfailure and reliability

Usually the research focuses on the number of failures per multi-unit or per wagon during a year. If multi-units are operated and recorded without re-forming them, then it is advisable to study the number of failures per multi-unit a year. If the composition of the multi-units constantly changes and the rolling stock's mileage is recorded for the wagons, then the number of failures per wagon a year is studied. One of the main indicators of the reliability theory is the failure intensity (in the reliability theory it is called an intensity density of a random event). This indicator is characterized by the number of failures (of a multi-unit or wagon) per mileage unit. The period between the repairs of some vehicles is characterized by kilometers (or thousands of kilometers), and sometimes by moto-hours (thousands of moto-hours). This depends on the recommendations from the rolling stock's manufacturer: the manufacturer provides the recommended type of a maintenance system. The railway companies usually comply with 
the repair system type recommended by the manufacturer, in order to avoid troubles during the technical operation of a rolling stock.

The following rolling stock operational parameters were used when modeling the failure intensity of a passenger rolling stock fleet: the number of failures per wagon (or per multi-unit) a year and the failure intensity, the number of failures per mileage unit (per $1000 \mathrm{~km}$ ) of a wagon (or multi-unit) or the duration of a rolling stock's operation (per 1000 moto-hours).

\subsubsection{Estimation of the electric multi-unit reliability}

In 2011-2012 the authors conducted a passenger multi-unit fleet's reliability research at LG. The fleet consisted of four RA-2 series diesel multi-units and 14 electric multiunits. During the research it was assumed that the reliability of the vehicles continuously declines at an established intensity as they age. When the fleet is supplemented with new rolling stock, the overall failure amount of the fleet declines proportionally to the number of the new rail vehicles. Consequently, the dependence of the number of failures per wagon on the average age of the electric multi-units was measured first. This dependence of the number of failures is shown in Figure 40.

During the five years of the study (2006-2010) the electric multi-unit fleet of enterprise LG had been renewed, so the average age of of fleet in every calendar year varied discreetly. The number of wagon failures per year fluctuated chaotically. These values - the average age of rolling stock fleet and the flow of failures - mathematically correlated with each other.

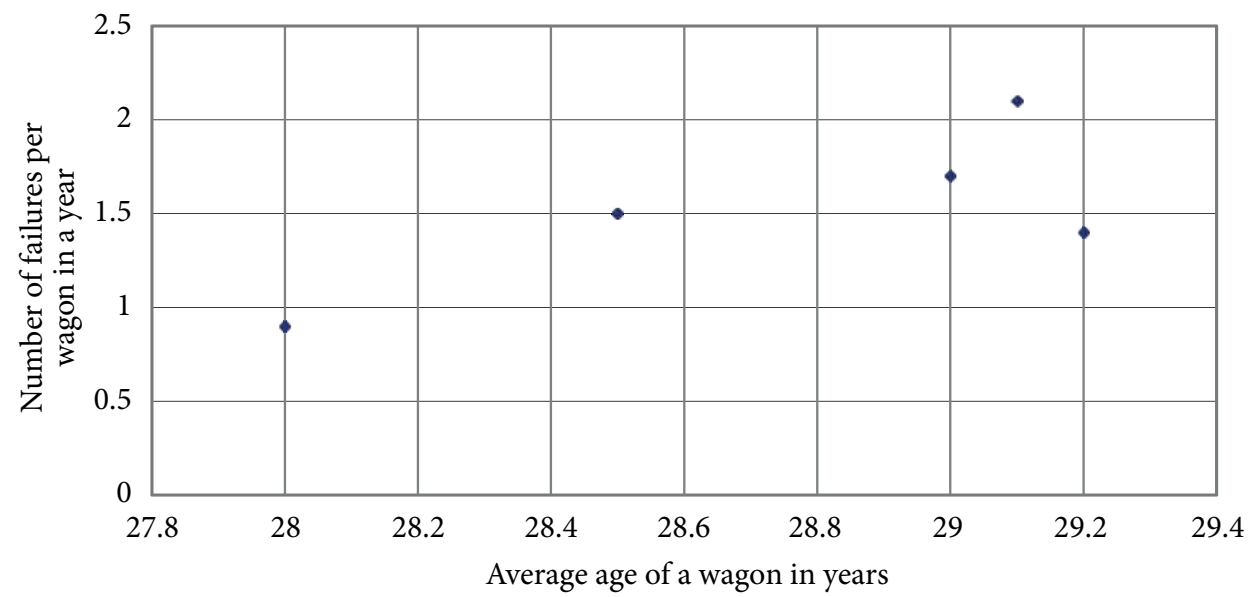

Figure 40. Dependence of number of electric multi-unit one wagon failures on wagon's average age 
The research results showed that, if the vehicles' age increases by one year, the number of their failures increases by $0.5-0.7$ per electric multi-unit's wagon a year. During the research it was assumed that, after installing new rolling stock to the electric multi-unit fleet, the average age of the fleet will decrease proportionally to the number of the installed multi-units' wagons. When the rolling stock fleet's average age decreases, the failure intensity decreases proportionally. The decrease of the electric multi-units' average age when their fleet is being renewed (by installing new rolling stocks) is shown in Figure 41.

The calculation results, presented in diagram form in Figure 41, showed that, if the electric multi-unit fleet was renewed each year by adding three wagons (this constitutes one electric multi-unit), after five years the average age of the fleet would decrease by 10 years. The electric multi-unit's failure amount is expected to decrease proportionally to the reduction of the fleet's average age. The dependence of the failure amount's decrease on the number of newly-acquired electric multi-unit wagons is shown in Figure 42.

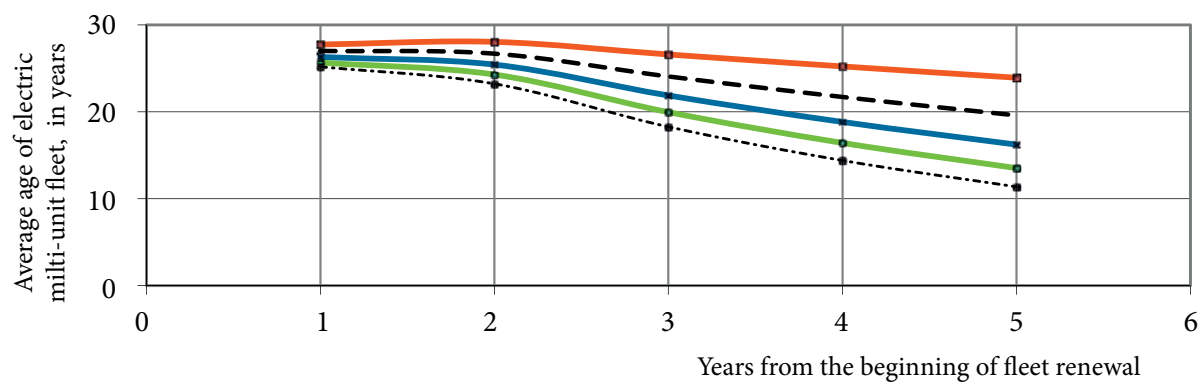

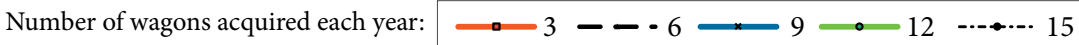

Figure 41. Decrease of the electric multi-unit fleet's average age during the fleet renewal process

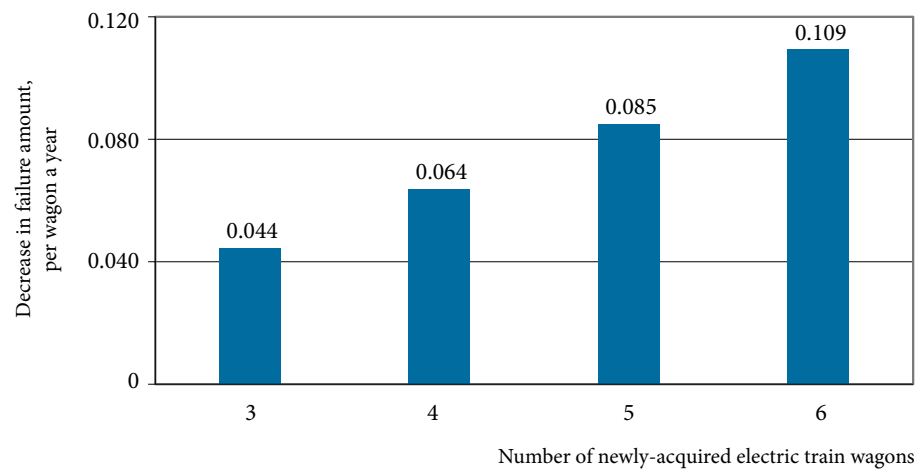

Figure 42. Dependence of the decrease in electric multi-unit failures on the number of newly-acquired electric multi-unit wagons 
The calculation results (the diagram in Figure 42) show that, if six wagons were acquired, the fleet's failure amount would decrease by 0.109 failures per wagon a year, and if three wagons were acquired, by 0.044 failures per wagon a year. This means that, on average, each newly-acquired electric multi-unit's wagon reduces the overall electric multi-unit failure amount by $0.015-0.018$ failures per wagon a year.

To sum up the results, the following preliminary conclusions of the electric multiunit reliability research are made. According to the results of the vehicle failure intensity research, a mathematical model was made that indicates a consistent pattern between regular renewal of the passenger vehicle fleet and the vehicle failure intensity. The mathematical model was implemented using the LG electric multi-unit fleet as an example. It was learned that, if the existent electric multi-unit fleet of 108 wagons was supplemented by one multi-unit (three wagons), the fleet's average failure amount ( 0.6 failures a year) per wagon would decrease by 0.044 failures a year; in other words, if $3 \%$ of the vehicle fleet was renewed, its failure amount would decrease by $7.3 \%$. This model can be used for predicting the change of failure amount when planning to acquire a small number of passenger vehicles (1-2 diesel or electric multi-units consisting of three wagons) for a period of several years (up to five year). In other words, the model is to be used for predicting the changes of electric multi-unit fleet's failure amount in the beginning of the fleet renewal (in the first decade of the new wagon mileage), when renewing the fleet by $10-20 \%$. This mathematical model should not be relied on when predicting the vehicle fleet's failure intensity for longer periods or bigger number of acquired vehicles. The model could be improved by evaluating more factors and their consistent patterns of influencing the vehicle failure amount. The essential weakness of this model is that it does not consider the aging process of the newly-acquired wagons and its influence on the whole fleet's failure amount. Further LG passenger vehicle researches showed that the vehicles with an internal combustion engine, i. e., diesel multi-units, have the most complex aging process (Gelumbickas and Vaičiūnas 2011; Vaičiūnas and Lingaitis 2008).

\subsubsection{Analysis of diesel multi-unit failure amount}

When studying the failure intensity of the vehicles with internal combustion engines, it can be seen that the intensity is closely related to the vehicle maintenance system type. In the beginning of operation, the failure intensity increases due to the peculiarities of installing the vehicles for operation. The rolling stock manufacturer is not always able to anticipate the real (factual) conditions of the produced vehicles' operation (e.g., load, usage intensity, climate conditions, maintenance work culture, etc.). Consequently, in the beginning of the vehicle operation the failure intensity increases for some time (such failures are sometimes called "childhood diseases"). During the unscheduled maintenance, these failures are removed, the most appropriate operational materials 
are selected (depending on the load, climate), as well as more experience on how to properly operate such vehicles is gained. The failure intensity decreases (stabilizes) for the time being. However, after a while, a permanent repair needs to be done. The vehicle constructions and materials used for manufacturing are constantly improving; therefore, each permanent repair of a vehicle is partly unique. After the repair, unforeseen consequences appear. Manufacturers' repair recommendations are not always explicit and specific. Various components and parts of a rolling stock are often produced by different manufacturers who provide completely different recommendations for operating and repairing the vehicles. For instance, the recommended period for changing engine oil is provided by both a diesel engine manufacturer and an engine oil manufacturer. The recommended period sometimes differs by two or even three times. When planning the works of vehicle's permanent repair, the decision makers of railway companies are not always certain which recommendations to follow. In such cases, the decision makers improvise. Such decisions not always are the best, resulting in the increase in rolling stock's failure amount when starting its operation after an ordinary permanent repair. When operating the rolling stock, the mistakes and defects made during the repairs are removed, therefore the resulting vehicle failure intensity decreases (is "contained") for the time being. But due to an elementary deterioration of rolling stock's parts, the failure intensity starts increasing again until the next permanent repair. Thus forms a periodic failure intensity's dependence on rolling stock's operation as the first permanent repairs are performed on a regular basis. The periodic failure intensity dependence of the LG diesel multi-units RA-2 on the diesel multi-unit mileage is presented in Figure 43 . The failure intensity values provided in the Figure 43 diagram are calculated as a ratio of the failure amount to multi-unit mileage.

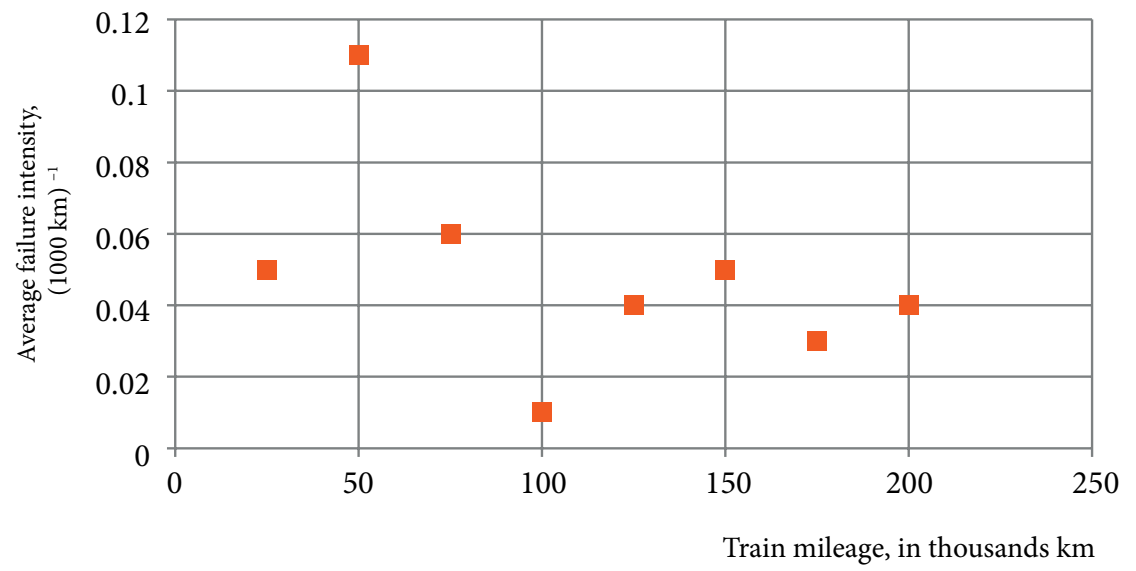

Figure 43. Failure intensity dependence on diesel multi-unit mileage 
The periodic failure intensity dependence on the diesel multi-unit mileage is characterized by the fact that, when the mileage is around $50,000 \mathrm{~km}$, the failure intensity peaks to more than 0.1 failures per $1000 \mathrm{~km}$ mileage. When the mileage reaches 100,000 $\mathrm{km}$, the failure intensity falls to 0.01 failures per $1000 \mathrm{~km}$ mileage, i. e. by ten times. Later, when the mileage is $150000 \mathrm{~km}$, the failure intensity rises again to $0.04-0.05$ failures per $1000 \mathrm{~km}$ mileage. Such a variation is determined by the scheduled diesel multi-unit repair warning system used by LG. Until the first permanent repair, the failure intensity stays at around 0.5 failures per $1000 \mathrm{~km}$ mileage; after the repair it increases more than twofold, later decreases by around 10 times due to the unscheduled repairs. After this cycle has passed, at 100-125 thousands $\mathrm{km}$ mileage the second cycle starts. Due to the repair peculiarities, the failure intensity this time increases not twofold, as in the first cycle, but only by a quarter (from 0.04 to 0.05 failures per 1000 $\mathrm{km}$ mileage). After $150,000 \mathrm{~km}$ mileage, the failure intensity decreases once more. When the mileage reaches around $200,000 \mathrm{~km}$, the failure intensity steadies around 0.04 failures per $1000 \mathrm{~km}$ mileage. The variation consists of $25 \%$; this is trivial compared to the variation during the first $100,000 \mathrm{~km}$ mileage. The amplitudes of this variation are likely to be reduced by improving the rolling stock repair technologies. It should be noted that the failure intensity itself is regular and its periodicity of a sinusoid form cannot be removed. Acquiring diesel multi-units on a regular basis, it would very unacceptable, if the failure intensity maximums of several multi-units coincided or "added up" (e.g., when the mileage of one multi-unit was $50,000 \mathrm{~km}$, the mileage of another multi-unit would be $150,000 \mathrm{~km}$ ). Such a coincidence would substantially destabilize the fleet's overall failure intensity, i.e., greatly reduce the technical readiness level of a fleet. When modeling the failure intensity, it was learned that the changes occur quite consistently, if diesel multi-units are acquired after every 50,000 km mileage under the formula " $2+2+1$." Such a change of the diesel multi-unit fleet failure intensity is shown in Figure 44.

When the diesel multi-unit fleet is formed under the formula " $2+2+1$ " (after every $50,000 \mathrm{~km}$ mileage), two diesel multi-units are installed at first. In Figure 44, this moment matches the 0 on the $\mathrm{X}$ axis. When the mileage of the first two multi-units reaches $50,000 \mathrm{~km}$ (reaches the maximum failure intensity), two more new diesel multi-units are installed. When the mileage of the first two multi-units reaches $100,000 \mathrm{~km}$ (the mileage of the other two multi-units then reaches $50,000 \mathrm{~km}$ ), one more diesel multi-unit is installed. The result of following such a method for rolling stock renewal (acquisition) can be seen in Figure 44. When the mileage of the first two multi-units is 50,000 $\mathrm{km}$, the curve in Figure 44 shows the maximum failure intensity. When the mileage of these multi-units is $100,000 \mathrm{~km}$, the curve in Figure 44 shows the maximum failure intensity of the other multi-units. When the mileage of the first multi-units is 150,000 


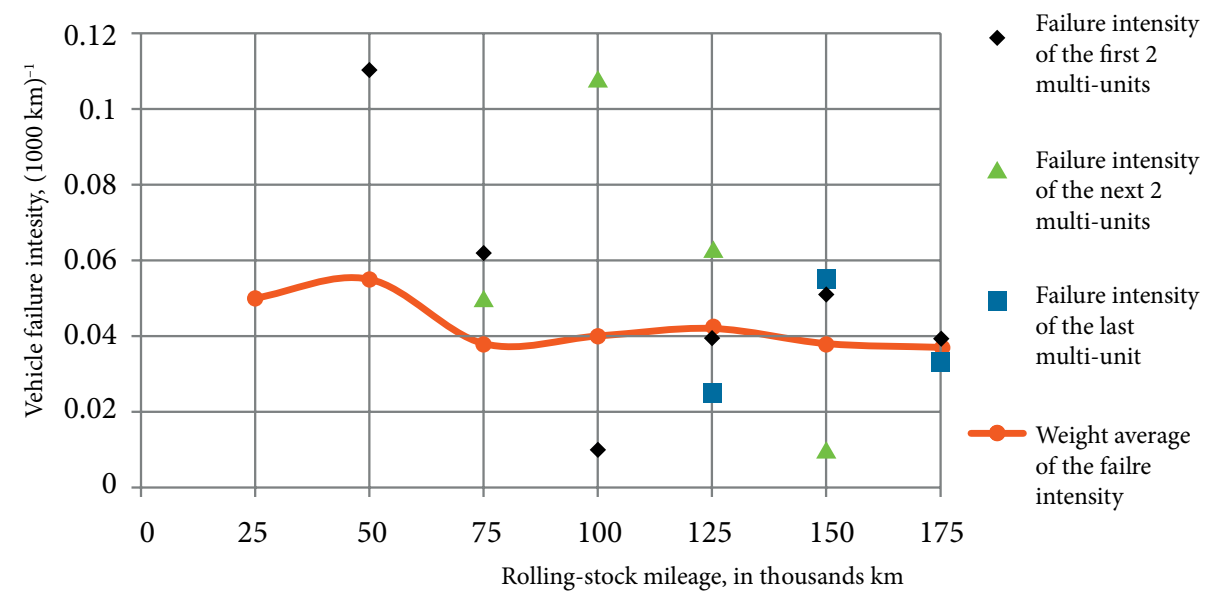

Figure 44. Failure intensity of diesel multi-unit fleet when the fleet is renewed according to the formula " $2+2+1$ "

$\mathrm{km}$, the curve shows the maximum failure intensity of the last multi-unit. The average failure intensity of a fleet is calculated as a weighted average, taking into account the number of diesel multi-units:

$$
\lambda=\frac{\sum \lambda_{i} \cdot n_{i}}{\sum n_{i}} ;
$$

where: $\lambda_{i}$ is the failure intensity of a multi-unit group (instalment) No. $i,(1000 \mathrm{~km})^{-1}$; $n_{i}$ is the number of multi-units of a multi-unit group (instalment) No. $i$.

After implementing the formula (1) on the $2+2+1$ basis, it would look like this:

$$
\lambda=\frac{\lambda_{1} \cdot 2+\lambda_{2} \cdot 2+\lambda_{3} \cdot 1}{5}
$$

It should be noted that, in the denominator of Formula (44), "5" appears only if all five multi-units are installed, i.e., if all three summands are in the numerator. The multipliers "2," "2," and " 1 " in the numerator are weighted coefficients that take into account the number of multi-units. The diagram of Figure 44 shows the failure intensity after the weighted coefficients are taken into account. That is why the maximum at $150,000 \mathrm{~km}$ mileage is two times lower than the two first maximums. The line curving around 0.04 failures per $1000 \mathrm{~km}$ mileage is the average failure intensity. The more appropriate modeling approach is when the continuous functions are used. The 


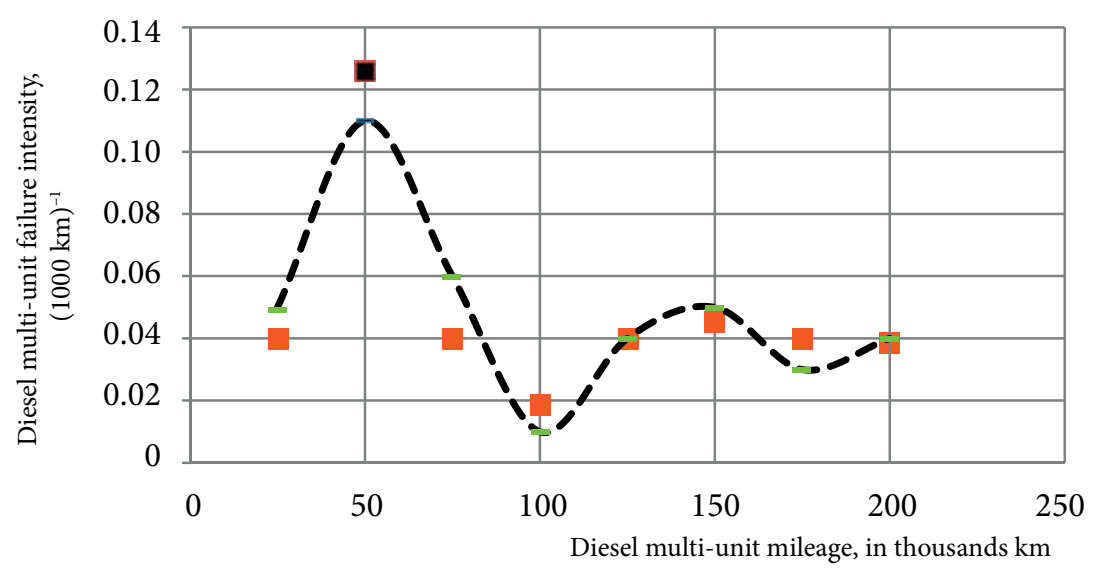

Figure 45. Approximation of diesel multi-unit failure intensity by continuous function

examples of modeling that have been presented above in text so far are the cases of discrete modeling. The failure intensity's (or another parameter's) values are discretely attributed to the mileage intervals based on which the required actions with the sets are performed. For visualization, the diagram points that represent parameters are connected, thus making the imitation of a continuous function. Such a modeling approach is simple, visual and is well-suited for modeling non-complex processes (when one or several extremes are present). However, if there are more extremes or the dependence function is more complex, then it is better to analyse the dependence by using the continuous function. Figure 45 shows an example of diesel multi-unit failure intensity's approximation by the continuous function.

In Figure 45, the discrete approximation of points function is made on the basis of the exponentially diverging sine function:

$$
\lambda=A \cdot e^{n} \cdot \sin (C \cdot x-B)+D
$$

where: $A$ is the amplitude coefficient; $B$ is the phase coefficient; $e^{n}$ is the decrease pattern; $C$ is the wavelength ratio; $D$ is the average divergence. The measuring units of $A$ and $D$ coefficients matches the measuring unit values marked according to the $\mathrm{Y}$ axis.

The units of coefficients $B$ and $C$ are radians per $1000 \mathrm{~km}$ or per 1000 motohours. The dispersion of the diesel multi-unit failure intensity equals 0.00095 . According to these values, a conclusion can be made that the approximation is fairly appropriate. 


\subsubsection{Applying of SPLINE method for multi-unit inter-failure modelling}

In mathematical science, the SPLINE approximation is a known method of compromise (Lyche and Morken 2008). Its basic principle is to divide the dependence function domain into segments where data is approximated by functions in such a way that they would form one consistent pattern. The points at which the diagram goes from one segment to the other are called spline knots. The most simple is the approximation by the splines of the second degree. Coefficients of quadratic equations are calculated from the condition that the derivatives of both functions at the spline knot must be equal. Thus, at that point the tangent of both function graphs is the same straight line. If the splines are made from the curves of the third degree (the function coefficients of the third degree are calculated), an additional condition appears, and stating that at the knots the second derivatives of the functions must also be accordingly equal. This method was also applied when researching the LG diesel multi-unit failure amount. At first, the approximation by the linear splines was used, later, the one by the second degree splines. A conclusion was made that the lowest spline degree, when the approximation is getting adequate to the physical phenomena, is the third one. As a basis for creating the third degree splines, the following equation is used:

$$
\mathrm{f}(x)=y_{i}+a \cdot\left(x-x_{i}\right)+b \cdot\left(x-x_{i}\right)^{2}+c \cdot\left(x-x_{i}\right)^{3} ;
$$

where: $x$ and $y$ are point coordinates; $a, b$ and $c$ are coefficients of the third degree equation. These last-mentioned coefficients are calculated according to the following formulas:

$$
\begin{gathered}
a=\frac{y_{i+1}-y_{i}}{x_{i+1}-x_{i}}-\ddot{f}_{i+1} \frac{x_{i+1}-x_{i}}{6}-\ddot{f}_{i} \frac{\left(x_{i+1}-x_{i}\right)}{3} ; \\
b=\frac{\ddot{f}_{i}}{2} \\
c=\frac{\ddot{f}_{i+1}-\ddot{f}_{i}}{6 \cdot\left(x_{i+1}-x_{i}\right)} .
\end{gathered}
$$

The following are the results of the solution found using the MAPLE software package. Practically speaking, this method has one limitation. The diesel multi-unit mileage is indicated in kilometers: $50,000 \mathrm{~km}, 100,000 \mathrm{~km}$ etc. The SPLINE diagram does not accept such indication method as it needs a reference system on the basis of $1,2,3$, 4, etc. Mark "2" of the SPLINE diagram matches the 50,000 km mileage, mark "4" 100,000 km, etc. Therefore, when reading the formulas and diagrams, the rolling stock mileage has to be calculated separately. Firstly, the splines are indicated 
by the formulas (third degree functions with corresponding coefficients, within the range of the " $x$ " mileage):

$$
\left\{\begin{array}{l}
17+\frac{1223}{1991} \cdot x-\frac{51453}{3982} \cdot x^{2}+\frac{17151}{3982} \cdot x^{3}, x<2 ; \\
\frac{238407}{1991}-\frac{305617}{1991} \cdot x+\frac{23217}{362} \cdot x^{2}-\frac{33989}{3982} \cdot x^{3}, x<3 \\
-\frac{587901}{1991}+\frac{520691}{1991} \cdot x-\frac{295485}{3982} \cdot x^{2}+\frac{27219}{3982} \cdot x^{3}, x<4 ; \\
\frac{640707}{1991}-\frac{400765}{1991} \cdot x+\frac{165243}{3982} \cdot x^{2}-\frac{11175}{3982} \cdot x^{3}, x<5 \\
\frac{94082}{1991}-\frac{72790}{1991} \cdot x+\frac{34053}{3982} \cdot x^{2}-\frac{2429}{3982} \cdot x^{3}, x<6 ; \\
-\frac{704254}{1991}+\frac{326378}{1991} \cdot x-\frac{99003}{3982} \cdot x^{2}+\frac{4963}{3982} \cdot x^{3}, x<7 \\
\frac{36663}{181}-\frac{148285}{1991} \cdot x+\frac{36615}{3982} \cdot x^{2}-\frac{1495}{3982} \cdot x^{3}, x<8 ; \\
\frac{779613}{1991}-\frac{289405}{1991} \cdot x+\frac{71895}{3982} \cdot x^{2}-\frac{2965}{3982} \cdot x^{3}, x<9 \\
-\frac{2266149}{1991}+\frac{725849}{1991} \cdot x-\frac{153717}{3982} \cdot x^{2}+\frac{5391}{3982} \cdot x^{3}, x<10 \\
\frac{160441}{181}-\frac{2671}{11} \cdot x+\frac{8013}{362} \cdot x^{2}-\frac{2671}{3982} \cdot x^{3}, \text { otherwise. }
\end{array}\right\}
$$

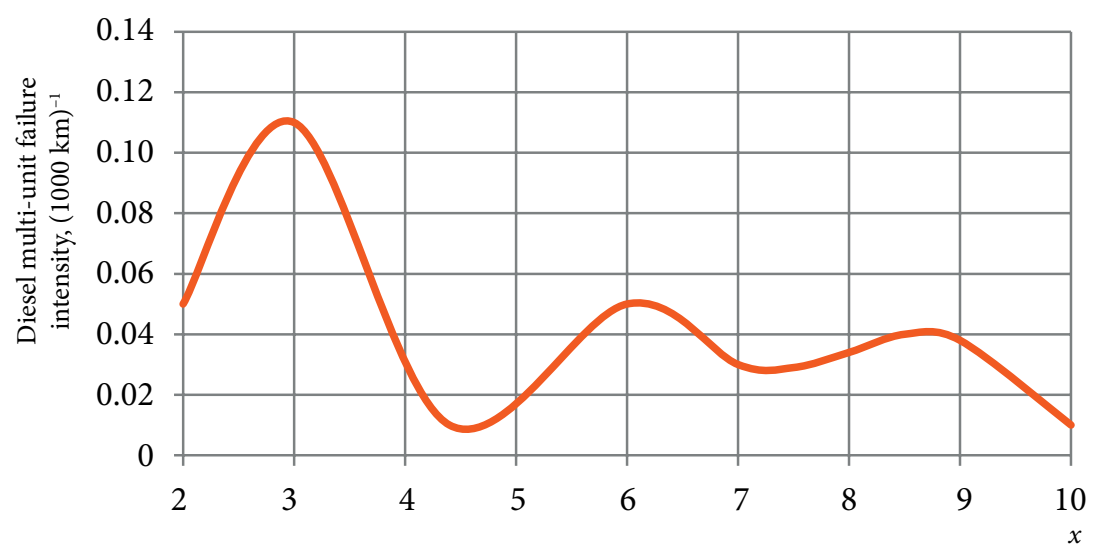

Figure 46. Approximation of diesel multi-unit failure data by splines of the third degree 
The domain is divided into 11 segments (subdomains) each of which has one consistent pattern (see Formula 50). This mathematical expression is shown in diagram form in Figure 46.

From the diagram in Figure 46, it is obvious that, using the spline method, a fairly complex pattern can be indicated by non-complex mathematical functions. This is very convenient for indicating the failure intensity of a rolling stock, in this instance, diesel multi-units. The main advantage of this method is that the spline limits (as well as the domain section limits) can be chosen according to the physical phenomena of a process. In the rolling stock operation this can be the maintenance regularity, or in certain cases, the moments of crashes or failures. After indicating the rolling stock failure patterns by one of the above-mentioned methods (discrete, continuous function, or spline), the failure patterns of the whole fleet of a railway company can be modelled in the longer term, taking into account the fleet formation (renewal) algorithm. After making such rolling stock renewing schedule, a railway operator can avoid the unwanted failure intensity peaks, as well as the unexpected costs of manpower and financial expenditures for repairing the rolling stock.

\subsubsection{Discussion}

During this study of the new rail vehicles acquisition influence on the fleet's overall failure amount, it was noticed that this influence depends on whether the fleet of RU is renewed or newly formed. If renewing a large existing fleet with a few dozen or hundred vehicles, then it can be assumed that the acquisition of the new vehicles reduces the overall failure amount of the fleet proportionally to the number of acquired vehicles. This assumption should not be applied when the fleet is newly formed. When forming a new fleet, the rolling stock is to be acquired in certain cycles. If the rolling stock failure intensity fluctuates, especially if the fluctuations are regular, the peaks of the newlyacquired vehicle failure intensity can coincide with the peaks of the earlier-acquired vehicle failure intensity. The research showed that, if the failure intensity fluctuation extremes coincide, the unexpectedly large peaks of the fleet failure intensity, as well as the vehicle repair costs, are possible. Therefore, when forming a new rolling stock fleet, it is necessary to, as gradually as possible, disperse in time the total failure intensity extremes.

In order to avoid the possible and unexpectedly large peaks of the whole rolling stock fleet failure intensity, it is necessary to mathematically model the patterns of their failure intensity dependence on operation, and to use these models for choosing the appropriate moment to install a new vehicle. For modeling the vehicle failure intensity dependence on operation, the discrete method, polynomial approximation, and sine pattern approximation are proposed. The more radical proposal of the authors is to 
approximate this pattern using splines. The latter method is convenient, as the spline limits can be chosen according to the physical phenomena of a process, thus evaluating the moments of maintenance.

After indicating the rolling stock failure patterns by one of the above-mentioned methods, the failure patterns of the whole vehicle fleet can be further modelled, taking into account the RU fleet formation (renewing) algorithm. After making such rolling stock fleet renewing schedule, in the future a RU can avoid the unexpected failure intensity peaks, as well as the unforeseen costs for unscheduled repairs of the rolling stock. 


\section{EDUCATION AND TRAINING ISSUES FOR EURASIAN LAND BRIDGE SUPPORT AND DEVELOPMENT}

IIIIIIIIIIIIIIIIIIIIIIIIIIIIIIIIIIIIIIIIIIIIIIIIIIIIIIIIIIIIIIIIIIIIIIIIIIIIIIIIIIIIIIIIIIIIIIIIIIII

\subsection{Introduction}

The development of the Trans-Eurasian land bridge depends on specialists and experts who can support and provide the appropriate progress and sustainability of this highspeed connection between Europe and Asia. Nowadays there is no joint Trans-Eurasian education system which could provide the Trans-Eurasian railways with specialists for support, maintenance, and development of this bridge. Differences in methods, principles, and standards of education have posed a challenge to Eurasian integration and the modernization of rail education. The integration of the railway systems of Europe and Asia, railway reforms in Europe, and the development and implementation of high technologies in this industry have radically changed the labor conditions of railway engineers and other specialists. This has led to an urgent necessity to improve the training systems, upgrade qualifications, and develop and harmonize training standards for railway experts in Europe and Asia by using the opportunities of the Eurasian transport corridor (Tsykhmistro et al. 2014).

Within the context of the $\mathrm{NEAR}^{2}$ project, an international group of experts researched and identified on the one hand problems, needs, gaps, and barriers in training, education, and staff development, and on the other hand the current situation, needs, and priorities in this area. The result of this research is the concept document that aims at identifying and presenting a framework of actions that will support the creation of a competitive Eurasian railway connection. The CD focuses on the following actions:

1) Comparison of rail education systems in countries along the Trans-European land bridge (Tsykhmistro and Cheptsov 2014); 
2) Identification of gaps in and barriers to the sustainable development of rail education (competences gap, gender gap, needs related to the harmonization of the rail educational standards in Europe and Asia, etc.);

3) Identification of market needs (labor market needs and needs in new educational methods, technologies, and principles);

4) Analysis of leading centers of rail education along the Trans-European land bridge;

5) Comparison of rail educational programmes in some European and Asian countries;

6) Development of the list of courses to be included in a potential masters-level course in railway engineering (an international MSc programme);

7) Identification and presentation of the interfaces with other CDs which were developed within the framework of NEAR ${ }^{2}$;

8) Identification of future research needs and priorities that will support the formulation of a research agenda for the Eurasian land bridge;

9) Identification of common future research projects related to the topics of interest of working groups, etc.

Railways of the Eurasian transport corridor eager to comply with transport service market requirements compete with motor, river, and air transport. So there is need for engineers and managers in the railway industry who can supervise the industry as a whole and understand its place in the single market system. Hence, there is an urgent need for training centers to prepare the experts that satisfy international standards.

This chapter is devoted to issues pertaining to education and future research in the field of specialist training and staff development to support the development of the Trans-Eurasian land bridge. The main objective of the research is to prove the necessity for the creation of a harmonized rail education and training system based on the international experiences, the rail educational standards, knowledge management tools and principles, and e-learning practices. Such a system would create the intellectual and professional basis for successful international competitiveness in the field of rail education. Existing rail education systems in countries along the Trans-Eurasian land bridge have been compared by the authors, and their advantages and disadvantages, along with existing gaps, future research needs, and priorities as a result of expert research and analysis are described. 


\subsection{Comparison of rail education systems in countries along the Trans-European land bridge}

The European and the Asian models of rail education are quite different in their nature (Figures 47 and 48).

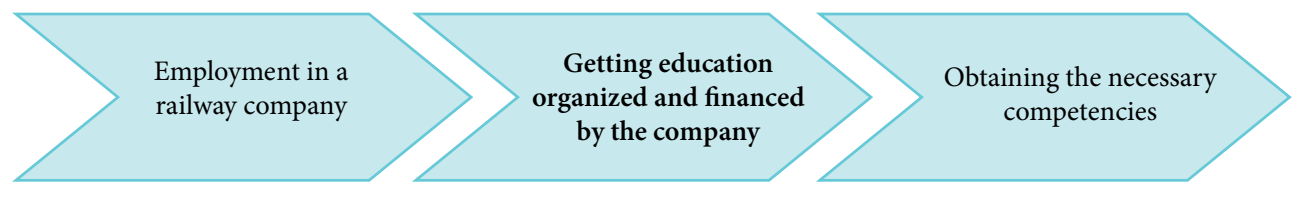

Figure 47. A rail education model in Europe (in general)

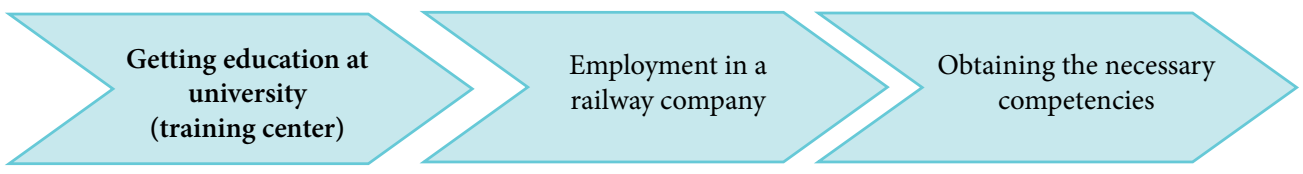

Figure 48. A rail education model in Asia (in general)

The European model of rail education supposes that firstly the railway company selects the staff and then trains them in compliance with its demands and technologies. Such an approach has essential advantages because it allows preparing the experts for a short time period to take on certain tasks of the company, and not expect them to retrain it from their university graduation days. But the flipside is that such experts lack some basic general knowledge and skills (interdisciplinary education) which finally impacts their competence level.

In Asia, the railway companies usually prefer to employ qualified experts who have been educated at railway institutes. Despite this, due to the large gap between the university education and the railway industry, the railway companies have to retrain the qualified experts because their competence levels are based on theoretical knowledge and they severely lack practical skills.

Thus one could say that neither European nor Asian systems of rail education suit modern requirements (standards) and that both of them need to be reformed.

The peculiarities of the rail education systems in several countries located along the Trans-Asian transport corridor are stated in Table 24. 
Table 24. The peculiarities of rail education systems in several countries located along the Trans-Asian transport corridor

Country $\quad$ Features of the rail educational system

The European railway industry is educating its personnel mainly in-house. Naturally, this has a direct influence on reducing the demand for rail training services. Although operational training is done in-house, some trainings, for example, those related to safety issues, might be outsourced. Generally, the market is considered to have a surplus of engine drivers, mainly because increased salaries and improved working conditions have attracted new people to the industry.

In Europe, the way to educate railway personnel is rather simple and systematic.

Europe Railway undertakings educate the engine drivers themselves. Although various external companies are offering courses, these are mainly extra courses and training, which are given only after the basics are known. The competence of employees is really important, and special attention is paid to how the work-related tasks are done. For example, in the maintenance sector, all employees need to go through an extensive number of courses. When starting in a maintenance company, the employee needs to have initial training and induction for safety which lasts two years. Thereafter there are annual re-assessments. This is in order to check that the person maintains his competency and skill levels.

The rail education system in CIS countries is clearly divided into higher and secondary technical education.

For employment in the structural subdivision of national railway companies (Russian Railways, Ukrzaliznytsya, Byelorussian Railway, etc.) at the engineering and management positions there needs to be special professional education (at a technical school and/or university).

Training of the experts in railway transport is held in profile high education

CIS countries institutions at all three qualification levels: bachelor's, master's/specialist, $\mathrm{PhD}$ (Ivanova and Shterengarts 2015).

At technical schools the specialists get a narrow-profile profession (electrical supply, rolling stock maintenance, bookkeeping, etc.).

In technical schools the preparation and upgrading of the personnel is conducted, namely personnel such as engine drivers, conductors, cashiers, station monitors, etc. In order to be employed at the State Enterprise Ukrzaliznytsia and its subdivisions, the profile rail education is necessary.

Training the railway engineers is performed in six profile institutes of the Ministry of Communication of India (narrow-profiled education) and the National Academy of the Ministry of Communication of India. This training is imparted as medium-

India term courses (from one to 10 weeks) aimed at various staff categories, from trainees to the highest management. It is not typical for the Indian rail education system to introduce a research component in the process of training. The main aim is the preparation of narrow-profiled experts within a short time.

The Korean rail education system is similar to the European one because the railway companies organize education for their employees by themselves. Higher education is aimed at preparation of the general technical profile (engineering, transportation, etc.). Training of the railway experts is provided by the national

Korea railway company KORAIL in its training centers. KORAIL employees can easily access a wide range of study programmes. The Korean rail education system is similar to the European one because the railway companies organize education for their employees by themselves. Higher education is aimed at preparation of the general technical profile (engineering, transportation, etc.). Training of the railway experts is provided by the national railway company KORAIL in its training centers. 
KORAIL employees can easily access a wide range of study programmes. The flagship centers include a Customer Service Academy to ensure passenger satisfaction, an International Railway Research Center to provide leading global railway education, a Leadership Academy to cultivate leaders in each business field, Specialist Training to cultivate the best specialists in marketing, rolling stock, electrics, communications, and facilities, and an ISO-certified Train Driving License Center to train and license drivers for each type of train. Since train operations can only be safe when all business aspects and systems are fully integrated and are in harmony, absolute priority is given to teaching employees to understand the training and work of other divisions. The contents and processes of some typical training programmes at each division are outlined here.

New employees start a three-phase training program involving an introductory training, on-the-job training (OJT) in their assigned departments, and work-field training. Introductory training takes the first two weeks after joining the company and involves getting to know the overall working of the system, suggesting creative ideas while visiting key worksites, and acquiring basic business knowledge to ensure that as new employees, they are useful and productive as soon as they are posted to their new assignment. After completing the introductory training, work begins at the worksite for some period, followed by basic training in the applicable work fields. The training goal for new employees is to reach work potential within six months of joining KORAIL (Figure 49).

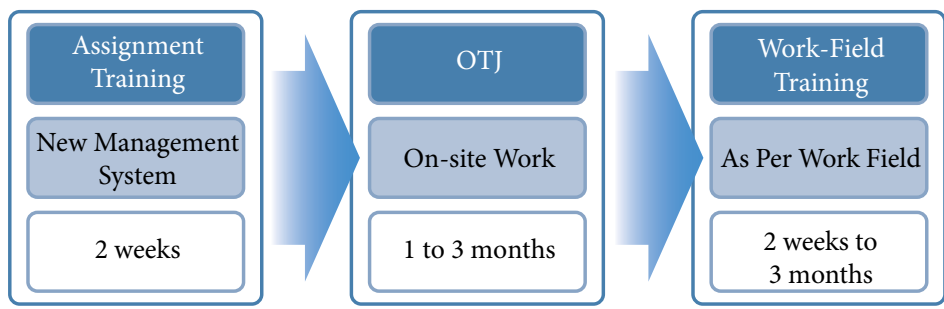

Figure 49. New employee training system

The KORAIL six-phase study model is used to give employees practical training over three months. Moreover, worker coaching is implemented, which gives a sense of unity among the workforce, to build a leading team capable of delivering the best results (Figure 50).

\begin{tabular}{|c|c|c|c|c|c|}
\hline STEP 1 & STEP 2 & STEP 3 & STEP 4 & STEP 5 & STEP 6 \\
\hline $\begin{array}{c}\text { Preliminary } \\
\text { Study }\end{array}$ & Group 1 & Practice 1 & Group 2 & Practice 2 & $\begin{array}{c}\text { Evaluation/ } \\
\text { Certification }\end{array}$ \\
\hline Goal Setting & $\begin{array}{c}\text { Problem } \\
\text { Sharing }\end{array}$ & $\begin{array}{c}\text { Project Im- } \\
\text { plementation }\end{array}$ & $\begin{array}{c}\text { Case Announ- } \\
\text { cement }\end{array}$ & $\begin{array}{c}\text { Project Im- } \\
\text { plementation }\end{array}$ & $\begin{array}{c}\text { Training } \\
\text { Completion }\end{array}$ \\
\hline $\begin{array}{c}\text { Subject } \\
\text { Choice }\end{array}$ & $\begin{array}{c}\text { Knowledge } \\
\text { Acquisition }\end{array}$ & $\begin{array}{c}\text { Applicable } \\
\text { Cases }\end{array}$ & Excellent Cases & $\begin{array}{c}\text { Experience } \\
\text { of Success }\end{array}$ & $\begin{array}{c}\text { Certification } \\
\text { Exam }\end{array}$ \\
\hline $\begin{array}{c}\text { Reading } \\
\text { Study }\end{array}$ & $\begin{array}{c}\text { Skill } \\
\text { Acquisition }\end{array}$ & $\begin{array}{c}\text { Regular } \\
\text { Reports }\end{array}$ & $\begin{array}{c}\text { Discovery/ } \\
\text { Making } \\
\text { Publicly Known }\end{array}$ & $\begin{array}{c}\text { Deliverable } \\
\text { Results }\end{array}$ & $\begin{array}{c}\text { Certificate } \\
\text { Presentation }\end{array}$ \\
\hline $\begin{array}{c}\text { Preliminary } \\
\text { Tasks }\end{array}$ & $\begin{array}{c}\text { Implemen- } \\
\text { tation Plan }\end{array}$ & Skill Training & $\begin{array}{c}\text { Project } \\
\text { Revision }\end{array}$ & $\begin{array}{c}\text { Knowledge } \\
\text { Registration }\end{array}$ & $\begin{array}{c}\text { Instructor } \\
\text { Activities }\end{array}$ \\
\hline
\end{tabular}

Figure 50. KORAIL six-phase study model 
Country $\quad$ Features of the rail educational system

In China railway training is provided in the railway colleges and universities of communication. The education system consists of three levels (bachelor's, masters', and $\mathrm{PhD}$ ) which corresponds to the European standards. The education lasts for four to five years.

To cope with the peak activity in railway construction in China and the reformation of the railway operation system, the railway colleges in the past years, have expanded their specialized courses and at the same time, have established new specialized courses in modern railway construction technology and new railway management systems. As a result, the total number of specialized courses at railway colleges exceeds 80 . With the new courses in commerce and economics, law, insurance, tourism, etc., the railway colleges are emerging as full-fledged universities. The colleges, that have widened their doors

China to meet the ever growing demand for railway personnel, strive to develop the potential of their students and develop the personnel needed for building a new society and for the development of the local railways.

In China, the railways and railway colleges have a very close relationship with each other. The Ministry of Railways paved the way for the establishment of colleges and actually founded railway colleges, and has since continued to help them develop. On their part, the railway colleges have educated hundreds of thousands of superior personnel over the last 100 years or more, and continue to support railway operations by supplying personnel required for efficient railway operations.

In addition, the individual railway colleges are involved in many diverse scientific research projects sponsored by the central, provincial, and municipal governments, and by the Ministry of Railways.

Modern railway experts, besides being trained in specialized disciplines, should be aware of the railway transportation market, to know the modern conditions of railway transport and its problems (Ivanova and Korobulina 2010). One important aspect of preparing specialists with international qualifications is the language skill. For example, many universities in Germany teach some of their subjects in English.

Railway enterprises make contact with the universities via the departments responsible for teaching the disciplines related to rolling stock or railway construction and operation. It is not the best option: the student does not study the problem of interrelation between the rolling stock and railway infrastructure, and organization of train traffic management. In this case, the university should develop the training program beyond the scope of the specialization. Such an approach is already being realized in the technical universities of Dresden and Berlin in the scope of the specializations of "Engineer of Communication" and in the "Course of Communication".

The main difficulties that the students of transport institutions face are, first of all, the need to obtain knowledge of general engineering disciplines, and then of specific transport-based ones. This is taken into account in the university programs of Dresden and Berlin, but there is still a problem. The up-to-date program of a general engineering program should ideally offer a choice of further pursuing a railway specialization (for example, related to rolling stock, transport economy, infrastructure, carriage planning). 
Classical education which includes studying the operation, planning, and projecting, forms the basis for the potential railway engineers, which will serve them in deeper studying of specialized disciplines. For example, such courses as Local Passenger Transportations, Cargo Transportations, and Far Passenger Communication include technique, economy, and marketing.

Due to the need to get a wide-profiled education, it is recommended that training programs include such disciplines as marketing, integrated transport planning, transport communication, computer studies, and land use. The students should also get acquainted with the modern working hardware, software, railway line projecting devices, etc.

\subsection{Harmonization of the rail educational standards in Europe}

A variety of education and training programmes with a focus on transportation, and rail transport in particular, exist within European and Asian institutions. These programmes vary in their scope and orientation, coverage, emphasis on different rail transport related topics, and target audience.

Due to the changing transport and economic environment, the educational needs of the next generation of rail transportation experts are also changing; they are becoming more interdisciplinary, technology oriented and multi-faceted. Collaboration among institutions for the purpose of reviewing, updating, and modernizing their educational programmes, and harmonizing them to the degree that is desirable and fits their scope, while keeping the specificities and focus areas of individual programmes, may assist in the direction of keeping up with current practices and following industrial developments.

The goal is to develop a synergistic approach to study issues relevant to the railroad industry both from an international and a regional perspective, using an international interdisciplinary approach to the problems. Based on this approach, the aim is to develop education and training programmes, which will capture the specifics and dynamics of the rail industry, addressing related issues, and closely studying the major trading regions of the world. The programmes will build an understanding of how the dynamics between trading regions and among the players in this industry affect the international trade and productivity of the rail transportation system.

A modern educational program should exploit the complementary strengths of collaborating institutions and experts to establish unique international interdisciplinary educational components, and build coordinated, integrated research capacities in the multidisciplinary and complex scientific fields of railroad productivity, engineering, management, policy, planning, and operations efficiency. A framework for integrating 
research and education and for promoting collaborative efforts across institutions spanning the two continents may be developed. Such collaboration will bring together an extraordinarily diverse intellectual community in the field of rail transport. A key issue is to have enough commonality in research and education to promote real collaboration among partner institutions, while keeping open multiple and diverse opportunities at a variety of international sites to promote participation by graduate students with diverse interests and goals (Danish Technological Institute ... 2007).

Participants in such collaborative educational initiatives will share:

I. an explicit focus on unravelling the details of interaction among the education and research themes, and on understanding how those interactions vary at different sites, based on history, economy, geography and culture; and

II. a focus on the pragmatics of multi-national research and education collaborations; participants will share their experience on how to overcome challenges to multidisciplinary, multinational collaboration in rail education.

The proposed educational components should combine the strengths of participating institutions with leading programs in rail transportation studies, to develop unique, truly international graduate programs. These programs may be modeled closely on existing international degree programs and will aim to provide participants with rigorous education that will challenge their intellect, expose them to excellent academic resources in rail transportation, and earn them a degree (a bachelor's or M.Sc. degree) or a certificate from leading institutions. The educational programs may be modular, each module (with thematic clusters) offered at a different university.

\subsection{Competences in rail education}

Cooperation between universities and the rail industry may assist in maximizing the performance of the industry as a whole, with benefits accruing to all stakeholders of the industry, research, and academia. Academic and research institutions should capitalize upon existing collaborations and build new ones with the rail industry to establish dynamic partnerships at a regional and international level.

The existing nucleus of the railroad experts in collaborating institutions such as those participating in the EURNEX ${ }^{49}$ and $\mathrm{NEAR}^{2}$ networks should be leveraged, to match all members' resources and abilities to address strategic, tactical and operational aspects of the regional and international rail industry in an integrated way. By forging strong partnerships among key stakeholders, the potential for success of the education, training, and research initiatives will be maximized, bridging theory and practice. The

\footnotetext{
${ }^{49}$ European Rail Research Network of Excellence
} 
existence of such strong industry-oriented initiatives assists in the direction of advancing a major sector of the global, regional, and national economy, and broadening the knowledge bases pertaining to rail transportation research and education.

Cooperation between universities and the rail industry, drawing on the broad range of existing academic and research strengths and capabilities, and matching them with the needs of the industry, have the potential to enhance our ability to bring critical insights to issues related to the rail industry.

Public sector agencies and private sector firms are experiencing several critical problems related to planning, managing, and operating the rail transport system. There is a need for experts who understand the global nature of the industry, the needs and issues of key industry players, the objectives and interactions among stakeholders, the statutory, regulatory, and institutional barriers, as well as issues related to operations, safety and security, and productivity-enhancing technology applications. Universityindustry collaborations are required to produce the proper programs to educate the next generation of railway experts and properly train the existing workforce that will be capable of addressing these issues.

One of the objectives of NEAR2 project Working Group 10 was to evaluate how well today's education meets the industry demands and needs. The analysis stated that neither European nor Asian rail education prepares the railway experts in compliance with the industry requirements of such experts. The main reason is the lack of university educational programs (rail education) harmonized with the current industry demands. The competence level of the graduates in universities usually does not correspond to the industry requirements for certain specializations, because in the process of university education the student's competence is formed based of excessive theoretical knowledge and lack of practical knowledge. The universities base their educational programs on what they can teach the student, not what they should teach them (Figure 51).

Universities have found it challenging to align their curricula with railway industry's needs and produce students with the relevant competences, skills, and knowledge. Several reasons can be identified that contribute to the this:

1. University-industry interaction is not included in the university's promotion and rewarding schemes.

2. Heavy teaching loads do not leave time for engagement in university-industry interactions.

3. University career development does not require interaction with industry, and many faculty members have never held a position outside of the university environment.

4. University research is valued in terms of publication records and not based on their practical nature for industry application. 


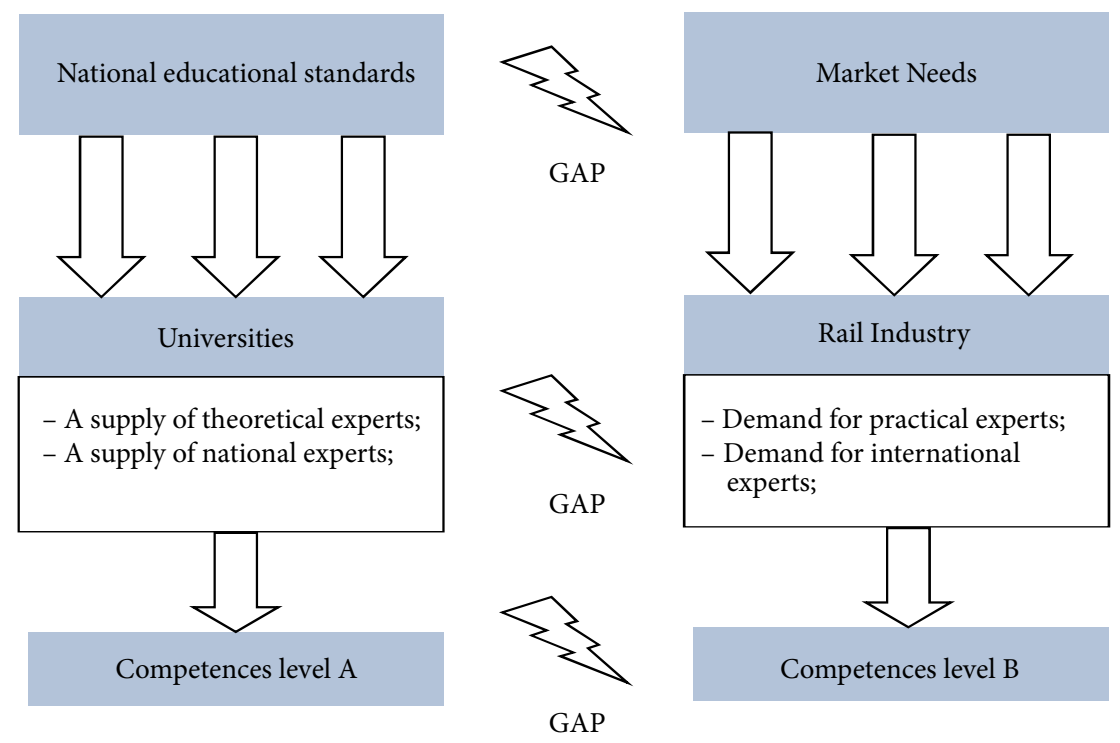

Figure 51. The occurrence of competence gaps

5. University research timing is not suitable for the industry's rhythm. The university develops research on long-term cycles and expectations, whereas the industry's goals are short-term oriented.

6. Economies are highly volatile and dynamic, and industries are always exploring and introducing new services and products. This economic paradigm constantly requires new knowledge, skills and competences, and both new and experienced employees are expected to keep up with such evolutions and requirements.

As a consequence of these problems, a competence gap between what is demanded by the industry and what universities can offer is visible, which is challenging at several levels. Firstly, the inadequacy of the students' skills and competences requires employers to invest in in-house training or search for professionals elsewhere. The need for training delays the time of the students' entry into the field and increases the costs for the employers. Secondly, the universities don't meet their main objective of educating and preparing students for the job market. Thirdly, the students are the main victims of the gap, starting from a disadvantaged competitive position vis-à-vis other workers and may have to endure further, and in many cases, self-funded education. Finally, if government funding channelled to universities does not generate the expected benefits, industries may lose their competitive edge and jeopardize the future development of the country.

As a result, there is a situation in the market where the industry demands and expectations of the graduates' competence level do not match. Because of this, the industry 
either needs to improve the graduates' competence by retraining them, or choose other personnel (for example, invite foreign experts). The competences gap was studied in detail within the SkillRail project (Figure 52).

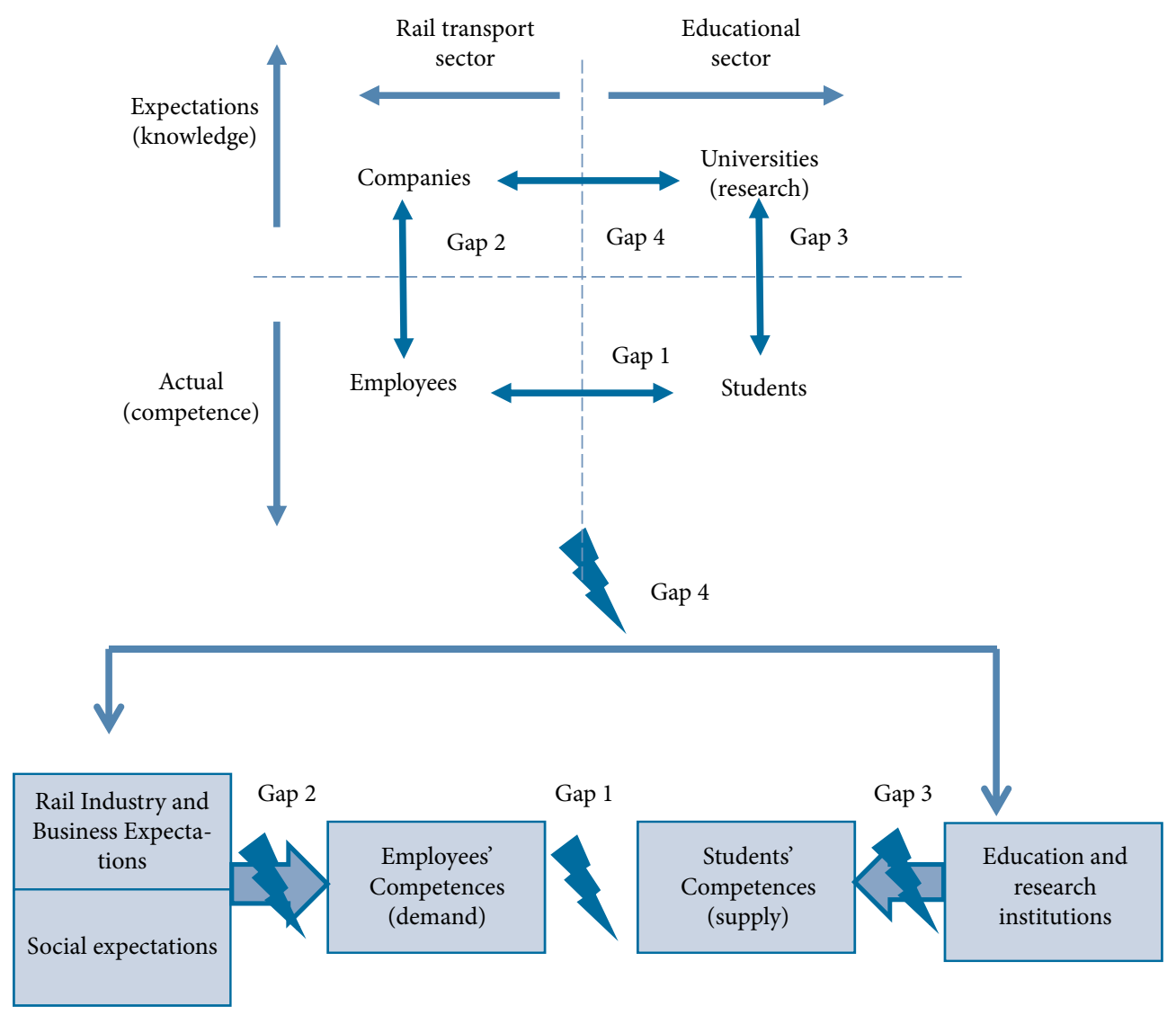

Figure 52. Graduates' competence gaps

A potential gap exists between each of the pairs, as follows:

I. First gap (competence gap): The gap between the competencies that the employees need and the actual competencies of the students

II. Second gap: The gap between the knowledge that the companies need and actually have

III. Third gap: The gap between the knowledge that the universities generate and the actual competencies of the students

IV. Fourth gap: The gap between the knowledge the companies need and the knowledge the universities have 


\subsection{Gender issues}

The rail industry has historically been male-dominated. However, times are changing, and women are making enormous contributions to all areas of railways, with more and more women taking on roles across the industry from train drivers, to engineers, to those in management positions.

The representation of women in the transport sector is rather low compared with the labor market as a whole. In 2005, only $20.5 \%$ of the EU27 transport workforce was women, compared with $43.5 \%$ of the total employment. The representation of women in the railway sector is less than $18 \%$. Also the division of labor is clearly gendered. Men are seen to work in technical and operational functions, whereas women work in service areas.

In non-EU countries, the gender gap is less than in Europe. For example, the percentage of women personnel in the Donetsk Railway, of the State Enterprise Ukrzaliznytsya, is as much as 44\%, as of the year 2013 (Figure 53).

The amount of women employed in the railway industry in other enterprises of the State Enterprise Ukrzaliznytsya is about $35-43 \%$, similarly to the Donetsk Railway. The situation is similar in all the CIS countries. For example, in Russia, the percentage of women employed at the OJSC Russian Railways is $30.4 \%$ (Figure 54).

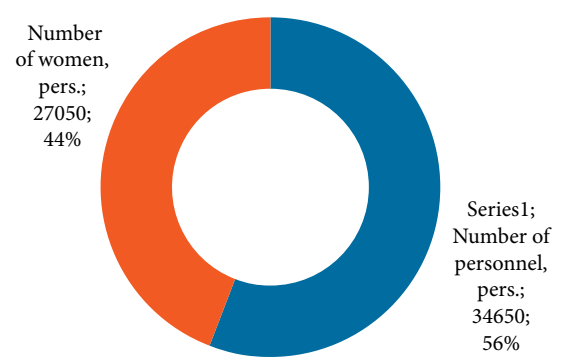

Figure 53. The number of women in the Donetsk railways of SE "Ukrzaliznytsya" (Ukraine)

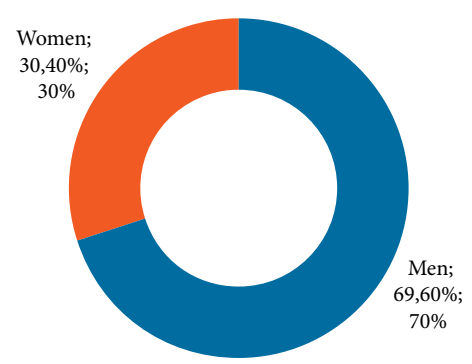

Figure 54. The number of women in the JSC "RZhD” (Russia)

The reasons behind barriers for women in the transport sector can be include the following:

A. the reluctance of employers to hire women;

B. poorer working conditions, in terms of wages, access to training, family-unfriendly working hours, male-centered working conditions, and the risk of violence and harassment;

C. cultural stereotypes that associate women and men with specific roles and tasks in the transport sector; 
D. a male-dominated sector that implies poor awareness of women's issues and rights, for instance, maternity leave, hours of work, part time jobs, shift patterns etc.; and

E. poor conditions for health and safety, such as insufficient radio contact or lightning, lacking sanitary rooms for women, etc.

The European rail sector is affected by globalization and demographic changes, which means that the composition of the work force is changing. To enjoy long-term success, the railway sector must make use of the potential of both men and women.

There are a number of arguments for why we need to achieve gender equality in the rail industry.

The resource argument: Women might have different experiences from men and can add new perspectives and themes to the agenda. Accordingly, the sector should use all available competences and resources as well as possible. It means that it is necessary to design a railway sector which offers improved access to women to prevent important competences and resources from being wasted.

The interests' argument: Women's interests should be represented in the railway sector. This will benefit both customer- and workforce-interests. It is worth noting that women's interests may vary due to ethnicity, class, nationality, or age, and that male dominance in the workforce might suppress women's interests.

The justice argument: Women have a right to participate on an equal footing with men, both individually and as a group. This is a fundamental democratic principle. An equal, balanced railway sector is therefore important simply to secure justice between women and men at an individual level, just as it will help ensure equal rights at a societal level.

Gender bias in the rail sector starts in the educational system. Basic courses and specializations often have a significant gender bias, which obviously makes gender-balanced recruitment policies more difficult. In this respect, the development of gender-balanced orientation practices for students is crucial.

Training programmes can be a means to qualify women for positions where they are currently missing, for example, jobs in the financial and operational part of the industry. However, the often higher responsibility of family affairs or part-time work that women have may pose a problem for long training programmes. Moreover, training is usually not often offered to part-time workers.

Women make up a small percentage in the transport industry, and that is why programmes tailored specially for them are rare. This is unfortunate, since different approaches to learning, different needs, or the discomfort of standing out can discourage women from enrolling for such programs.

In practice, there are almost no methods in place to motivate women to get a profile education and further employment in the railway industry. 


\subsection{Rail e-learning}

Harmonization of the rail education standards is possible by providing opportunities for remote education. Given that the railway communication along the Eurasian transport corridor extends for $11,000 \mathrm{~km}$, mass education of specialists with international levels of competence can be organized only by means of remote training.

Despite the active development of remote education today, rail education is still outof-date with the modern trends. In 2008, there a joint European project was launched called TEMPUS RELNET IB-JEP-27114-2006: Expansion of Cooperation of the Universities of Russia on the Basis of Implementing the Remote Education (E-Learning) for Requalification and Upgrading Qualification for the Transport Employees.

Virtual education provides enforcement of the individual's control over studying the requalification program for each student, and facilitates the preparation for testing. The main advantage of such a form of education is the absence of the need to disrupt the working process of employees studying either compulsory or voluntary programs for requalification and upgrading qualifications.

At the present moment, some Russian universities (Saint Petersburg State University of Communication and Far East State University of Communication) offer the following courses remotely: Safety Provision at the Railway transport for Non-Common Use, Management and Marketing at Transport Logistics Systems, Ecological Management and Eco-auditing Practice. These courses may be used by the experts in the transport industry for upgrading their qualifications. Besides these, there are also such virtual courses such as Marketing Fundamentals, Marketing Research, Special Roads of Industry Enterprises, which may be used for upgrading qualifications of experts, as well as for teaching and testing the students of full-time and part-time rail education.

A unified model for developing remote courses aimed at the railway industry (Kim 2009) was proposed by another European project "SkillRail" (see Figure 55).

Nowadays many railway universities use remote education systems in the training process (based usually on Moodle software). However, remote education programs are only considered auxiliary tools to the main education process, and are not treated as independent courses. The reason for this is the absence of a single methodology to organize remote rail education both at the national and international level.

We should also pay attention to the fact that rail education has a business-related nature, which requires learners to obtain practical skills and knowledge. At the present moment, remote rail education consists only of the theoretical studying, but this problem may be tackled by means of using different simulation and training systems in the form of web-applications. 


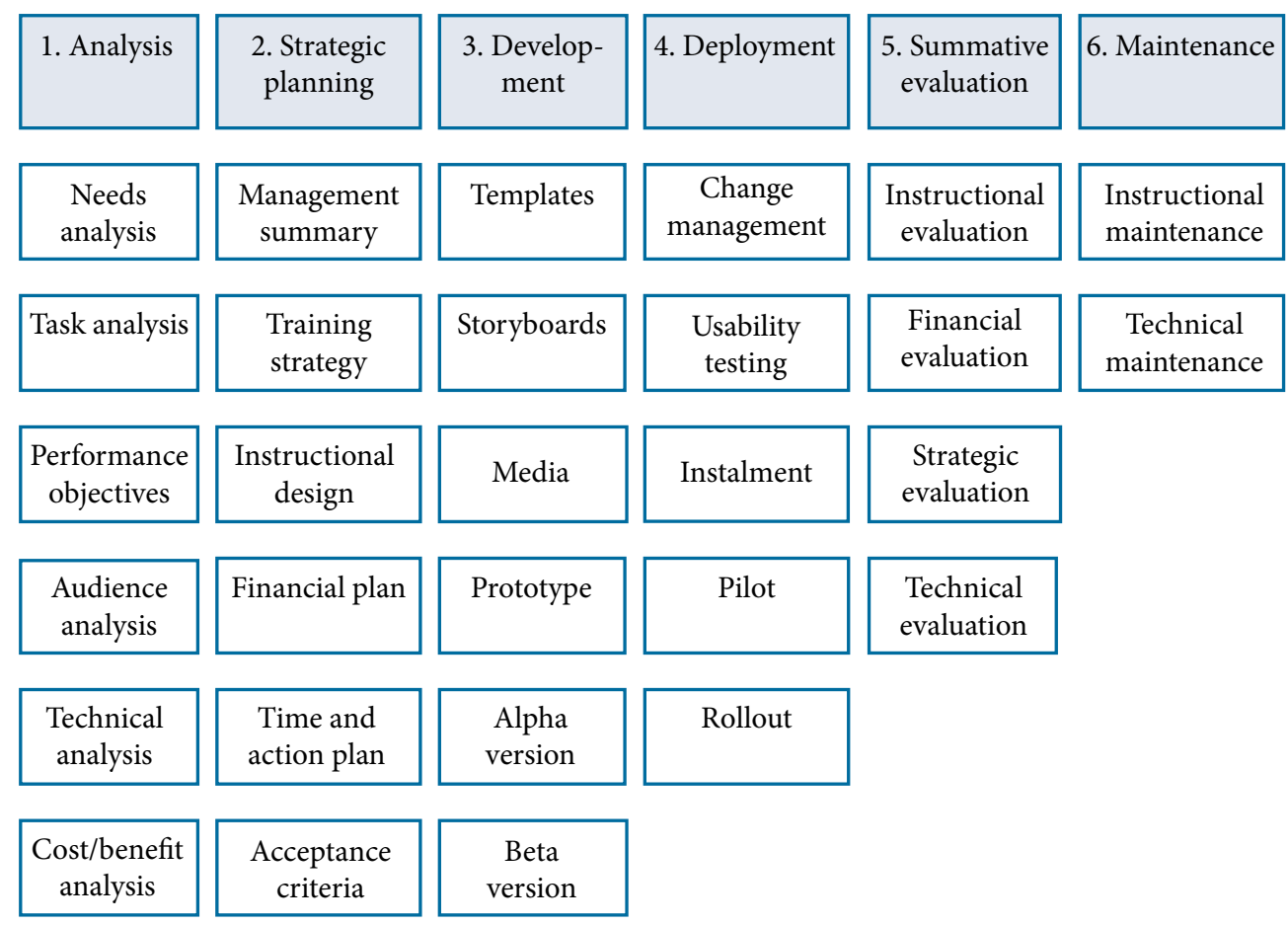

Figure 55. Model of development rail e-learning courses (Source: "SKILLRAIL Project")

Using web technologies in the personnel qualification system for the railway industry is necessary for the stable development of the whole system. Nowadays certain large universities and research centers use web technologies for developing rail education and science only partially. Given the internationalization of education, it is very important factor to provide students and scientists with access to the results of scientific research. The following educational and scientific web resources have become very popular in the last few years (Figure 56).

Fig. 56 shows that the up-to-date technical facilities provide large opportunities for organizing the education process with using web-technologies. Unfortunately, nowadays neither European nor Asian universities use such opportunities to their fullest extent; they are being applied by universities only partially. This is due to the absence of the knowhow about the methods, principles, and concepts of these technologies and how to use them in training the railway transport experts.

One of the ways to use web technologies here is the creation of profile video portals (YouTube channels) with video lecture-based courses offered by experts in the railway transport industry (see Fugure 57). 


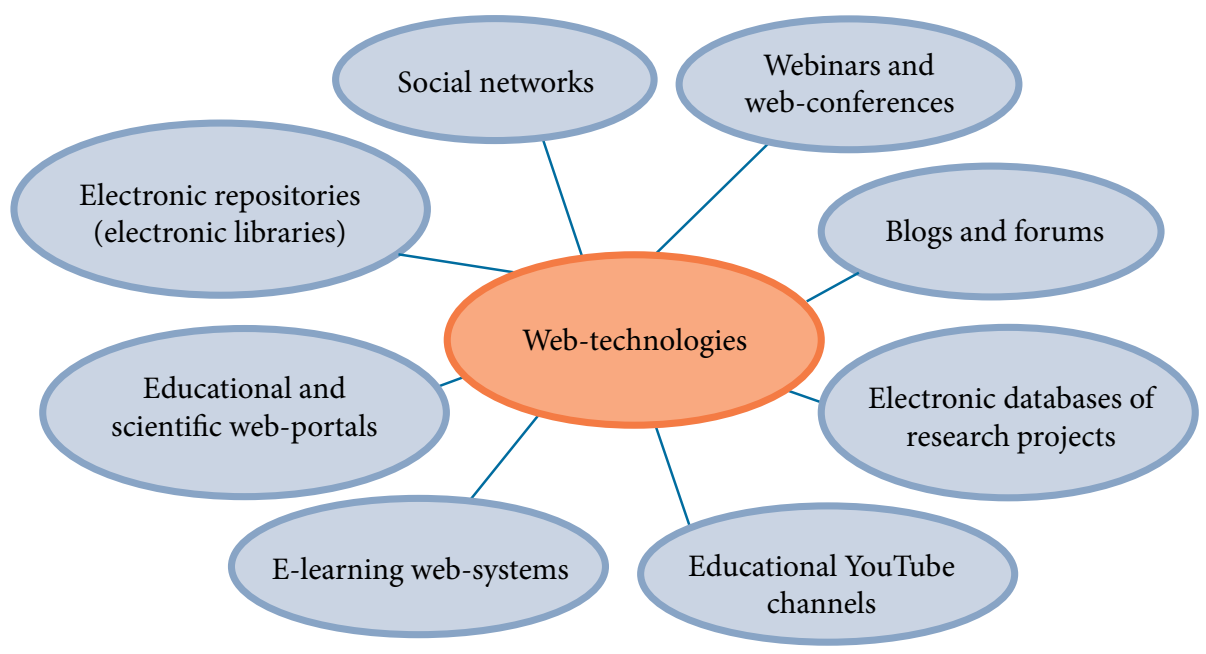

Figure 56. Web-technologies which may be used in the personnel qualification system for the railway industry

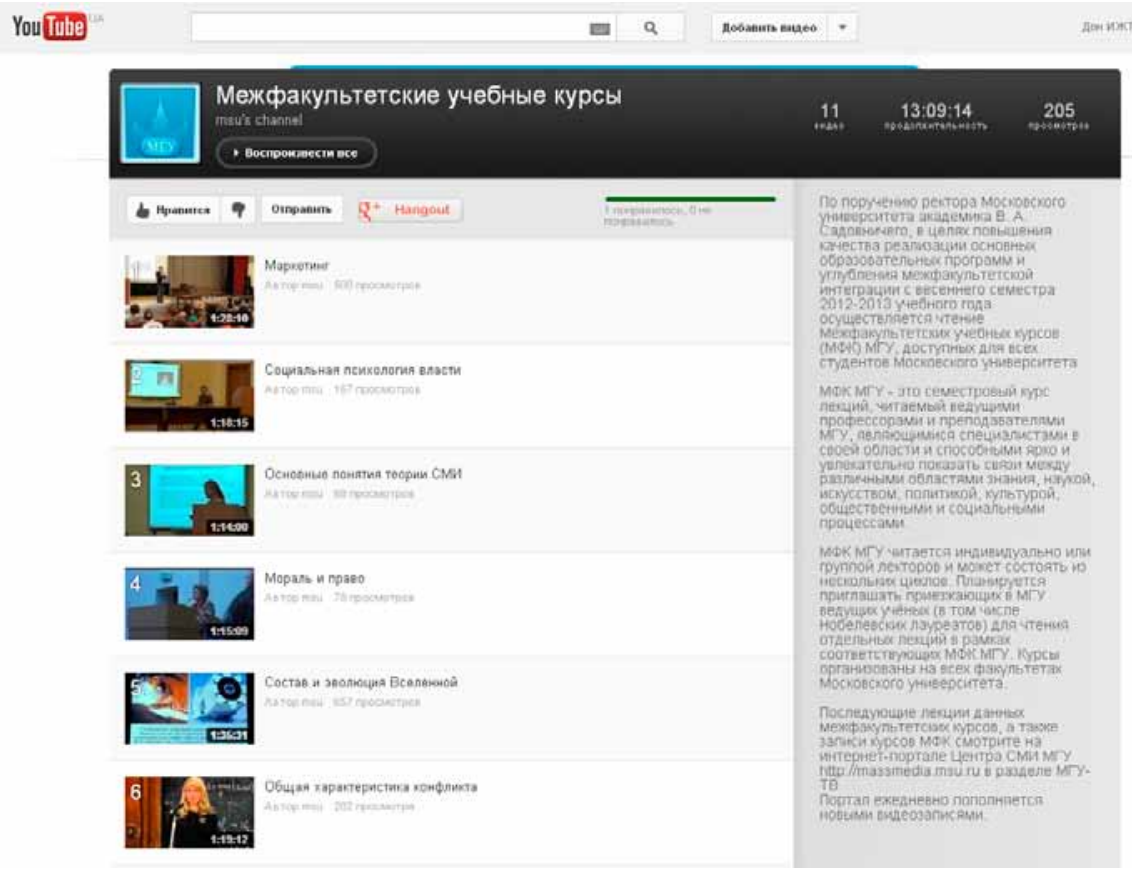

Figure 57. Video channel of the Moscow State University 
Another way to use web technologies in education is by the organization of webinars (Figure 58).

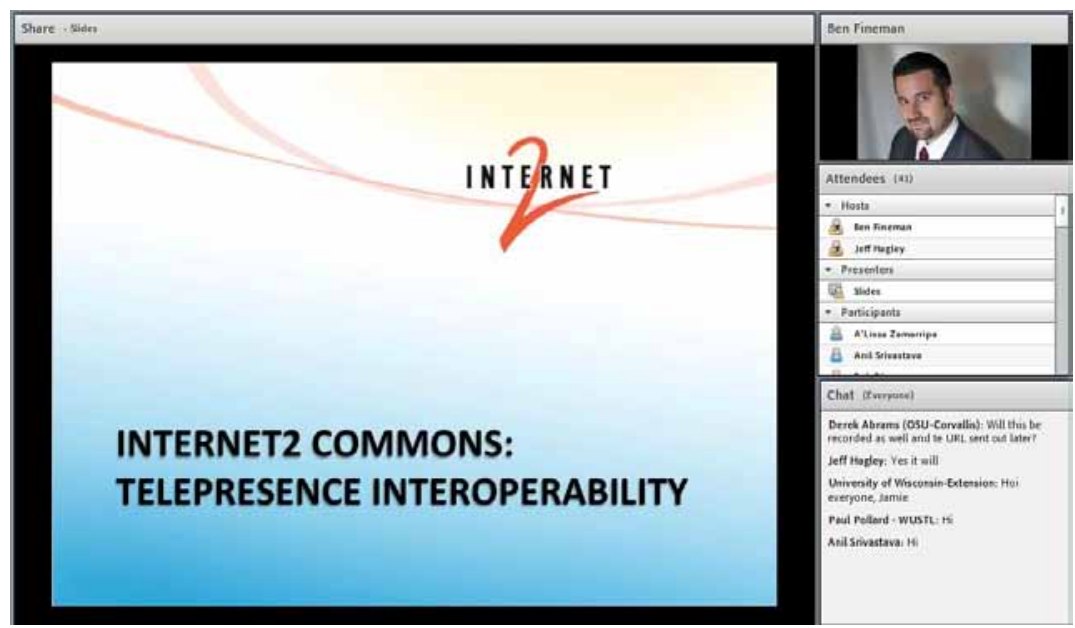

Figure 58. Webinar interface in education

Webinars are useful educational tools as they can reach a very large, widespread audience, given the minimal financial costs involved. The use of presentation materials and the chance to directly interact with the speaker makes the experience similar to how it would be with a real or live audience.

\subsection{Identified disadvantages, gaps, and barriers}

On the basis of the ideas discussed above, it is possible to identify and determinate the main drawbacks of currently existing Eurasian educational and training systems (Lautala et al. 2011):

1. The railway industry rarely takes part in the educational aspect of development at the profile railway universities. As a result, there are competence gaps. Railway companies prefer to prepare the experts in the training centers of their enterprises without active involvement in the educational programs in universities, while also being eager to employ university graduates with bachelor's and master's degrees.

2. There are differences in national standards of rail education along the TransAsian land bridge.

3. In the rail education systems of the countries located along the Trans-Asian transport corridor, there is a competence gap between the university education and industry demands. This is because the national education standards either 
do not correspond with or are not upgraded to meet the market demands.

4. Most of the training programmes are developed to train men, and focus on physical exercises.

5. In the railway technology industry, there is no single methodology and approach to developing educational portals. On the Internet there are almost no web resources devoted to rail education and railway science.

6. The trend of creating and filling the electronic repositories (open access systems) is poorly developed in the railway universities and research centers of Eastern Europe and Asia.

7. There is no single methodology to organize remote rail education.

8. There is no contact with the industry in the existing form of remote rail education.

9. There is no coordination between universities in different countries regarding remote education.

10. There is no single Eurasian platform for remote rail education, which complicates the development of rail education in general.

\subsection{Future research needs and priorities}

The European and Asian railways are facing fundamental legal, technological, demographic, and market changes that the railway sector needs to deal with in the coming years. Future research priorities in relation to human resources in Eurasian railways are presented in Table 25.

Table 25. Future research needs and priorities in relation to human resources

\section{Policy activities}

Initiate research to investigate opportunities for harmonization of rail education and training standards along the Trans-European land bridge

To define a common EU qualification standard for rail staff and for trainers
Support academic mobility of students and researchers between the universities along the Trans-Asian land bridge

Support of initiatives

\section{Organization activities} for the development of cooperation between universities and railway companies along the Trans-Asian land bridge

\section{Research activities}

Develop strategies (or roadmaps) for industry on how to develop university-industry collaboration

Continue rail system comparisons between Europe and Asia with emphasis on developing a set of metrics along Eurasian land bridge

\section{Gender activities}

Development of motivation programs with an aim to increase the number of women in the sector of rail education and research

Development of the concept of elimination of gender inequality in the system of rail education and training. 


\begin{tabular}{|c|c|c|c|}
\hline Policy activities & Organization activities & Research activities & Gender activities \\
\hline $\begin{array}{l}\text { Support initiatives } \\
\text { to develop Dual pro- } \\
\text { grammes and Double } \\
\text { degree programmes }\end{array}$ & $\begin{array}{l}\text { Development of joint MS } \\
\text { or PhD programmes that } \\
\text { include mandatory vis- } \\
\text { its by candidates to the } \\
\text { other side of Trans-Asian } \\
\text { land bridge. }\end{array}$ & $\begin{array}{l}\text { Creation of educa- } \\
\text { tional web resources } \\
\text { in the field of railway } \\
\text { transport }\end{array}$ & \\
\hline \multirow[t]{4}{*}{$\begin{array}{l}\text { Support initiatives to } \\
\text { create educational web } \\
\text { resources in the field } \\
\text { of railway transport }\end{array}$} & $\begin{array}{l}\text { Establish rail higher } \\
\text { education data reposi- } \\
\text { tory to store and dissem- } \\
\text { inate data on available } \\
\text { educational offerings in } \\
\text { Europe and Asia and to } \\
\text { support easier identifica- } \\
\text { tion of synergies between } \\
\text { universities }\end{array}$ & $\begin{array}{l}\text { Development of new } \\
\text { rail educational tech- } \\
\text { nologies }\end{array}$ & \\
\hline & $\begin{array}{l}\text { Establish an internet- } \\
\text { based knowledge da- } \\
\text { tabase and related web } \\
\text { portal to collect rail- } \\
\text { related knowledge from } \\
\text { university teachers from } \\
\text { different parts of the } \\
\text { world }\end{array}$ & $\begin{array}{l}\text { Adaptation of rail } \\
\text { education to the chal- } \\
\text { lenges of transition } \\
\text { period in rail sector }\end{array}$ & \\
\hline & $\begin{array}{l}\text { Creating a single virtual } \\
\text { rail university to imple- } \\
\text { ment the tasks of dis- } \\
\text { tance training along the } \\
\text { Trans-Asian land bridge; } \\
\text { involvement of railway } \\
\text { companies and universi- } \\
\text { ties along Trans-Asian } \\
\text { land bridge to provide } \\
\text { education on a single } \\
\text { e-learning platform }\end{array}$ & & \\
\hline & $\begin{array}{l}\text { Development of a single } \\
\text { database of publications } \\
\text { in the field of railway } \\
\text { technology (e-library) } \\
\text { along the Trans-Asian } \\
\text { land bridge }\end{array}$ & & \\
\hline
\end{tabular}

Liberalization, internationalization, and changes in the demographic composition of the workforce create changes in the skills needed within the European and Asian railways, for them to stay in business (Danish Technological Institute ... 2007). 


\subsection{Future aims and trends}

Further scientific and research projects related to the railway connection of Europe and Asia regarding rail education should be aimed at achieving the following:

1. Searching for mechanisms to develop cooperation between the universities, research centres, and railway companies

2. Determining the reasons for gender gap and developing recommendations on how to motivate women to get education and do research in railway technologies

3. Making a comparative analysis of the higher rail education systems in Europe and Asia for the purpose of further development of standards for creating and teaching the training courses, and for unifying the approaches to teaching specialists in the railway industry

4. Conducting a research of European and Asian railway companies aimed at:

a) determining the demand for graduates with certain railway specializations;

b) determining the demand for innovative specializations;

c) determining the requirements of the knowledge/skill level and general competence of the graduates of railway institutes;

d) analysing the current level of the rail education in Europe and Asia;

e) developing recommendations on improving the efficiency of cooperation between universities and railway companies;

f) detecting priorities in preparing railway experts for the purpose of optimizing the rail education system;

g) analysing the opportunities and development of the concept of the Eurasian Virtual Railway University;

h) analysing the national peculiarities of creating professional competences among the students of railway universities in Europe and Asia;

i) developing the concept and methodology of using web technologies in the process of rail education (development of educational web portals for rail education);

j) analysing the existing practice of holding laboratory and practical studies at the railway universities of Europe and Asia as well as developing a unified approach and methodology for creating laboratory and practical studies related to rail education; and

k) creating scientific and educational clusters of railway technologies for the purpose of developing international scientific cooperation, transferring knowledge and technologies, and building cooperation with the industry. 


\section{DISCUSSION AND OVERALL CONCLUDING REMARKS}

IIIIIIIIIIIIIIIIIIIIIIIIIIIIIIIIIIIIIIIIIIIIIIIIIIIIIIIIIIIIIIIIIIIIIIIIIIIIIIIIIIIIIIIIIIIIIIIIIIII

\subsection{Considering the rail traffic safety and interoperability}

As this analysis has depicted, the operation of railways poses significant challenges within the wide-ranging geographical/ climatic zones and different national cultures covered by the Eurasian landbridge. For this reason, it is of great importance to continue with the formulation and implementation of common policies regarding rail safety and security. It is thus highly desirable that all countries involved their obligation to implement the rail safety regulations, to take the necessary actions with regard to all other competent state administrators, and to ensure the ratification/ validation and/or implementation of conventions, agreements, or resolutions that facilitate railway safety and security.

Further research, development, design, testing, and assessment procedures of railway traffic risk control or monitoring methods should be performed. European and Asian countries should ensure the harmonization of their national transport regulation rules, especially through the facilitation of safety and security regulations, and this way guarantee rail traffic safety and passenger/freight security. Barriers for interoperability can be diminished once international arrangements such as "Convention concerning International Carriage by Rail (COTIF)" are applied by many countries. However, the gauge difference between Eastern Europe, Central, and Western Europe will remain a bottleneck for the growth of the rail market share. The construction of a $1,520 \mathrm{~mm}$ gauge connection in Central Europe could be helpful for specific links and for specific market segments such as container transport.

The following issues have been identified as the major priorities related to railway traffic safety in Eurasian corridors:

1) investigation of interoperability and safety progress issues in EU countries, Ukrainian, Belarusian, Russian, and Asian countries;

2) actualization of certification procedures of railway equipment for the securing of free access for infrastructure of $1520 \mathrm{~mm}$ gauge space; 
3) introduction of Common Safety Methods (CMS) and Common Safety Criteria (CSC) for assessment of railway safety on the Eurasian land bridge;

4) creation of a database for railway safety monitoring in the Eurasian railway corridors.

\subsubsection{Ensuring interoperability and safety along the possible railway connections}

Removing of remaining administrative and technical barriers is essential, in particular through the establishment of a common approach to interoperability and safety rules, to decrease administrative costs, to accelerate procedures, to increase economies of scale for RUs, and to avoid disguised discrimination.

\subsubsection{Implementation of a common rail safety and security policy}

CSMs harmonize the modification process and guarantee that the existing safety levels are properly monitored and maintained. The overall objective of these safety measures related to risk assessment is to facilitate access to the railway transport service market and allow cross-acceptance of the results. The future success of the Eurasian railway land bridge strongly depends on the use of feedback of experiences, the ability to monitor and measure the progress of interoperability, and the ability to identify the reasons for the lack of progress.

\subsubsection{Exploration of rail infrastructure and rolling stock maintenance quality monitoring}

This is needed to specify how to manage the life cycle of all interlocking systems and equipment that will be used for the EU-Asia connection (design, requirements specification, development, production, operation, and disposal). Rolling stock maintenance and repair/ technical inspection intervals, the training and qualifications of the maintenance and control centre staff, and the quality assurance system set up by the operators concerned in the control and maintenance centres must be such as to ensure a high level of safety.

\subsubsection{Railway operation and traffic management}

Essential capacities to reach relevant efficiency of railway traffic:

1) alignment of the network operating rules and the qualifications of drivers and on-board staff, and those of the staff in the control centres must be such as to ensure railway safety operations, bearing in mind the different requirements of cross-border and domestic services; 
2) revising of compatibility of TSI CCS, ETCS, ERTMS and EIRENE systems with non-EU countries and Asian corresponding Train Communication Network and Control System;

3) explore the means of TSI CCS, ETCS, ERTMS, and EIRENE systems harmonization with non-EU countries and Asian corresponding Train Communication Network and Control System.

\subsubsection{Telematics applications for freight and passengers:}

1) the interfaces between these two service systems and users must comply with the minimum rules of ergonomics and health protection;

2) suitable levels of integrity and dependability must be provided for the storage or transmission of safety-related information.

\subsubsection{Investigation of railway accidents:}

1) the purpose of investigations should be to make safety recommendations for railway operators of Europe-Asia corridors based on the findings of the investigations, in order to prevent accidents and incidents in the future and improve railway safety and security in the whole trans-continental land bridge/ corridor;

2 ) at the preliminary stage, one can use more modest and common mathematical methods for identifying of rail traffic risk level, such as Analytic Hierarchy Process, proposed by the authors;

3) assessment of the existing degree of interoperability, as well as the safety levels in the trans-Eurasian railway corridors;

4) investigation and implementation of CSMs for traffic safety risk control along the whole Eurasian railway connection;

5) harmonization or adjustment of standards/ specifications/ rules for rail safety and security, and traffic risk assessment, and track installation design, dimensioning, and construction;

6) creation of CSMs for traffic safety risk control along the whole Eurasian railway connection;

7) assurance of a common railway safety and security policy in Eurasian countries;

8) definition of certifications to access the railway infrastructure of different countries;

9) feasibility studies on the various acceptable solutions for rail certification procedure;

10) description of the harmonization/ validation of rail vehicle authorization;

11) identification of the main elements of the various railway safety policies in European and Asian countries and a comparison between them in order to analyse the compatibility and harmonization. 


\subsection{Considering the technical aspects and rolling stock maintenance}

Relevant research areas and the challenges of ensuring steady freight train traffic through the sustainable infrastructure are related to these identified gaps in and barriers to the Eurasian-wide harmonization:

1) unification/ harmonization of standards and specifications for tracks, civil engineering structures, and track installation design, dimensioning, and construction;

2) definition of specifications for the adoption of a permanent right-of-way (track superstructure and substructure) that will allow, for any case of exploitation (mixed train operation - with presence of conventional or high speed passengers' trains - or merely freight corridor), the movement of the freight trains based on the operational and design characteristics;

3) ensuring of a common track maintenance policy along entire Eurasian railways corridors;

4) Track-side automated control equipment (TACE) - the integral systems of HotAxle Box Detection (HABD), Hot Wheels detection (HWD), and Wheel Impact Load Detector (WILD) - in the entire Europe-Asia railway corridors should be revised to ensure railway safety and security;

5) implementation of rolling stock maintenance quality monitoring in entire corridors taking into account railway traffic safety indexes;

6) formulation of a maintenance plan in order to equate the maximum permitted speed to the design speed; formulation of a plan for the upgrade of the existing infrastructure in order to meet that goal;

7) establishment of a common way to estimate/measure the quantitative impact of the axle load increase to the design, constructional, and operational elements of a railway infrastructure;

8) implementation of a high-standard railway connection/network between Europe and Asia that will provide a high level of service for freight railway transports, more competitive than the other modes of transport;.

9) little information about the maintenance and critical limits for various parts of a wagon are available in EN standards and accepted across Eurasian countries, which could be an obstacle to ensuring the safety impact of rolling stock maintenance;

10) a minor share of freight locomotive fleet in Eurasian corridors are equipped with wheel slip and slide control systems, especially in Russian Railways. The authors did some research on how to implement or upgrade these systems. The implementation of these systems in locomotives should ensure stable and 
uninterrupted cargo flow down the Eurasian railway corridors, and a perceptible decrease in energy consumption as well;

11) the developed experience (the determination/ correction of rail vehicle repair frequency, the strategy of rolling stock renew, etc.) in the maintenance systems for rolling stock should be reflected in the rail vehicle operation.

\subsection{Considering staff training and education}

Further scientific and research needs related to the railway connection of Europe and Asia regarding rail education can be expressed as three tasks:

1) developing standards for creating and teaching the training courses and for unifying the approaches to teaching specialists in the Eurasian railway industry;

2) determining the reasons (obstacles) for a gender gap and developing recommendations regarding increasing the interest (motivation) of women in getting educated and doing scientific research in the area of railway technologies;

3) Making a comparative analysis of the higher rail education systems in Europe and Asia for the purpose of doing research in European and Asian railway companies aimed at:

a) determining the demand in graduates;

b) determining the requirements in the knowledge/skill level and general competence of the graduates of railway high schools;

c) developing recommendations to improve the efficiency of cooperation between universities and railway companies/ undertakings;

d) detecting priorities in preparing railway experts for the purpose of optimizing the rail education system;

e) analysing the opportunities and the development of the concept of the Eurasian Virtual Railway University;

f) analysing the national peculiarities of creating professional competences among the students of railway universities in Europe and Asia;

g) developing the concept and methodology of using web-technologies in the process of rail education (development of the educational web portals for rail education);

h) analysing the existing practice of holding laboratory and practical studies at the railway universities in Europe and Asia as well as development of the unified approach and methodology for creating laboratory and practical studies related to rail education;

i) creating scientific and educational clusters of railway technologies. 
To guarantee the sustainable development of rail freight transport as the safest and most environmentally-friendly mode of land transport, the following must be taken into account both in European and Eurasian railway corridors:

1) additional non-coordinated inspections on a national basis should be eliminated;

2) immediate inspection of all axles is not feasible due to lack of workshops and technical equipment capacities, and lack of qualified staff;

3) general reduction of axle load until further inspection would result in a noticeable increase of transport costs.

The aforementioned recommendations would be a modest way to consolidate the safety and interoperability level of the European-Asian rail corridors. 


\section{REFERENCES}

\section{|| || || ||||||||||||||||||||||||||||||||||||||||||||||||||||||||||||||||||||||||||||||||||||||||||||||||||}

Agrawal, M. K., A. Misra, and R. Dhawan. 2010. "Frequently Asked Questions on Wheel Impact Load Detector (Wild).” Indian Railway Technical Bulletin LXVI(332): 10-14.

Al-Najjara, B., and I. Alsyouf. 2003. "Selecting the most efficient maintenance approach using fuzzy multiple criteria decision making." Internationl Journal of Production Economics 84: 85-100.

Antoniak, J. 1990. Urzadzenia i systemy transportu podziemnego w kopalniach. Katowice: Wydawnictwo Śląsk.

Andersson, E., M. Berg, and S. Stichel. 2007. Rail vehicle dynamics. Stockholm: Royal Institute of Technology, Division of Rail Vehicles.

Bąk, R., and T. Burczyński. 2001. Wytrzymałość materiałów z elementami ujęcia komputerowego. Warszawa: WNT.

Barden Precision Bearings. 2008. Bearing failure: Causes and cures. http://www.bardenbearings. com/scan\%20pdf/Bearing\%20Failure\%20Brochure_2008.pdf.

Bashiri, M., H. Badri, and T. H. Hejazi. 2011. "Selecting optimum maintenance strategy by fuzzy interactive linear assignment method." Applied Mathematical Modelling 35: 152-164.

Bearfield, G., and W. Marsh. 2005. Generalising event trees using Bayesian networks with a case study of train derailment. Computer Safety, Reliability, and Security. Vol. 3688: 52-66.

Bearfield, G, Mitra S., and E. M. El-Koursi. 2004. Guidelines for Safety Management System, D2.2.2/V3.0. http://samnet.inrets.fr

Berthier, Y., S. Descartes, M. Busquet, E. Niccolini, and C. Desrayaud, L. Baillet, and M. C. Baietto-dubourg. 2004. "The role and effects of the third body in the wheel-rail interaction." Fatigue \& Fracture of Engineering Materials \& Structures 27: 423-436.

Braess, H. H., and U. Seiffert. 2000. Vieweg Handbuch Kraftfahrzeugtechnik. Wiesbaden: Friedrich Vieweg \& Sohn Verlagsgesellschaft GmbH.

Bucher, F., K. Knothe, and A. Theiler. 2002. "Normal and tangential contact problem of surfaces with measured roughness." Wear 253: 204-218.

Bureika, G. 2008. “A mathematical model of train continuous motion uphill”. Transport 23(2): 135-137.

Bureika, G. 2011. "Multicriteria evaluation of operational effectiveness of freight diesel locomotives on Lithuanian Railways." Transport 26(1): 61-68.

Cacciabue, P. C. 2005. "Human error risk management methodology for safety audit of a large railway organisation." Applied Ergonomics 36(6): 709-718.

Cantos, P., Jose M. Pastor and L. Serrano. 2000. "Efficiency Measures and Output Specification: The Case of European Railways." Journal of Transport and Statistics 3(3): 61-68. 
Chang, H. and L. Ju. 2008. "Effect of consecutive driving on accident risk: a comparison between passenger and freight train driving." Accident Analysis and Prevention 40(6): 1844-1849.

Cheng, Y. H. and H.L. Tsao. 2010. "Rolling stock maintenance strategy selection spares parts' estimation, and replacements' interval calculation.” International Journal of Production Economics 128: 404-412.

Cherry, C. R. 2005. “Development of duration models to determine rolling stock fleet size." Journal of Public Transportation 8 (3): 57-72.

Chen, H., T. Ban, M. Ishida, and T. Nakahara. 2008. "Experimental investigation of influential factors on adhesion between wheel and rail under wet conditions." Wear 265: 1504-1511.

Chen, H., M. Ishida, and T. Nakahara. 2005. "Analysis of adhesion under wet conditions for threedimensional contact considering surface roughness." Wear 258: 1209-1216.

Choe, H.C., Y. Wan, and A.K. Chan. 2008. "Neural pattern identification of railroad wheel-bearing faults from audible acoustic signals: comparison of FFT, CWT, and DWT features." http:// www.ece.tamu.edu/ akchan/Demo/paper_97.pdf

Dailydka, S., L. P. Lingaitis, S. Myamlin, and V. Prichodko. 2008. "Modelling the interaction between railway wheel and rail." Transport 23(2): 236-239.

Danish Technological Institute. 2007. Rail training 2020: Training needs and offers in the European railway a rea the next $10-15$ years. Lloud's register. $160 \mathrm{p}$.

http://ec.europa.eu/transport/modes/rail/studies/doc/2007_rail_training_2020.pdf.

Davey, J., A. Wallace, N. Stenson, and J. Freeman. 2008. “The experiences and perceptions of heavy vehicle drivers and train drivers of dangers at railway level crossings." Accident Analysis and Prevention 40(3):1217-1222.

Directive 2008/57/EC of the European Parliament and of the Council of 17 June 2008 on the interoperability of the rail system within the Community (Recast)

Directive 2004/49/EC on Safety on the Community's railways and amending Council Directive 95/18/EC on the licensing of railways undertakings and Directive 2001/14/EC on the allocation of railway infrastructure capacity and the levying of charges for the use of railway infrastructure and safety certification (Railway Safety Directive), L164 p44-113, 29 April 2004, Official Journal of the European Union.

Directive 96/48/EC on the interoperability of the trans-European high-speed rail system, Commission of the European Communities, Brussels, 23 July 1996.

Directive 2001/16/EC of the European Parliament and of the Council on the interoperability of the trans-European conventional rail system, Commission of the European Communities, Brussels, 19th March 2001.

Djukič, M., S. Rusov, and Z. Mitrovič. 2010. "A fuzzy model for an increase in locomotive traction force." Transport 25(1): 36-45.

Eisenbrand, E. 2011. Hot box detection in European railway network. RTR Special. System \& Signal Technic GmbH.

El-Koursi, E. M., S. Mitra, and G. Bearfield. 2007. "Harmonising safety management systems in European railway sector." Safety Science Monitor 11(2): 1-14.

El-Koursi, E., M, Fletcher.S, Tordai, L, and Rodriguez, J. 2006. "SAMNET Synthesis Report, Safety Management and Interoperability", SAMNET Final report. www.samnet.info 
Emerson, M., and W. E. Vinokurov. 2009. Optimistaion of Central Asian and Eurasian Trans-continental Land Transport Corridors. EUCAM.

Encoder catalogue. 2003. Germany. https://www.kuebler.com/PDFs/kataloge_publikationen/english/shortform_catalog_gb.pdf

Ertz, M., and F. Bucher. 2002. "Improved creep force model for wheel/rail contact considering roughness and temperature." Vehicle System Dynamics Supplement 37: 314-325.

Ertz, M., and K. Knothe. 2002. "A comparison of analytical and numerical methods for the calculation of temperatures in wheel/rail contact." Wear 253: 498-508.

Falco, P. J. H., M. C. MIMechE, and L. A. M. Dongen. 2013. "Application of remote condition monitoring in different rolling stock life cycle phases." In Proceedings of the 2nd International Through-Life Engineering, 135-138.

Fuest, K., and P. Döring. 2007. Elektrische Maschine und Antriebe. Lehr- und Arbeitsbuch. Wiesbaden: Vieweg.

Gelumbickas, G., and G. Vaičiūnas. 2011. "Analysis of passenger rolling stock faults and its statistics in Lithuania." Transport 26(3): 315-319.

Gerdun, V., T. Sedmak, V. Sinkovec, I. Kovse, and B. Cene. 2007. "Failures of bearings and axles in railway freight wagons." Engineering Failure Analysis 14(5): 884-894.

Gleave, S. D. 2011. Evaluation of Regulation 881/2004. Final Report for the European Commission. Directorate General for Mobility and Transport DM. London.

Harrison, H., T. Mccanney, and J. Cotter. 2000. "Recent developments in COF measurements at the rail/wheel interface." In Proceedings of the 5th International Conference Contact Mechanics and Wear of Rail Wheel Systems, 30-35. Tokyo, Japan.

High Precision Drives and Systems. 2001. Material-catalog of firm Maxoп Motor. Sachseln: Maxoп.

Hou, K., and J. Kalousek. 2000. “Thermal effect on adhesion in wheel/rail interface.” In Proceedings of the Fifth International Conference Contact Mechanics and Wear of Rail Wheel Systems, 239-244. Tokyo, Japan.

Hoeprich, M., R. 1996. “Rolling-element bearing internal temperatures.” Tribology Transactions 39: 855-858.

Holm-Hansen, B. T., and R. X. Gao. 2000. "Structural design and analysis for a sensor-integrated ball bearing." Finite Elements in Analysis and Design 34(3-4): 257-270.

Howard, I. 1994. A review of rolling element bearing vibration Detection, Diagnosis and Prognosis. Australia: DSTO Aeronautical and Maritime Research Laboratory.

Hu, Y. Z., and D. Zhu. 2000. "A full numerical solution to the mixed lubrication in point contacts." Transactions of ASME Journal of Tribology 122: 1-9.

Impact Assessment. 2013. Europe Commission. Commission staff working document. Brussels. 30.1.2013. SWD (2013) 8 final. 120 p. http://ec.europa.eu/smart-regulation/impact/key_ docs/docs/iab_report_2013_en.pdf

Inarida, S.; Kojima, T; Shimada, M. and S. Masuda 2001. “Train Traction Systems for Passenger Comfort and Easier Maintenance." Hitachi Review 50: 134-138.

Ivanova, N., and O. Korobulina. 2010. “The Electronic Market of Innovations and Knowledge on a Railway Transport”. Final report of cross-border project called LOGNET. Lappeenranta university of technology. 
Ivanova, N., and A. Shterengarts. 2015. "Key aspects of the development and implementation of an experimental model of the third level of higher education." Higher Education in Russia 12: $157-166$.

Iwnicki, S. 2006. Handbook of Railway Vehicle Dynamics. CRC Press, Boca Raton. Taylor and Francis. 535 p.

Jafari A, M. Jafarian, A. Zareei, F. Zaerpour. 2008. "Using fuzzy Delphi method in maintenance strategy selection problem." Journal of Uncertain Systems 2(4): 289-298.

Jastremskas, V., G. Vaičiūnas, O. Černašèjus, and V. Rudzinskas. 2010. "Investigation into the mechanical properties and metal creaks of a diesel locomotive wheel." Transport 25(3): 287-292.

Kabo, E., and A. Ekber. 2005. "Material defects in rolling contact fatigue of railway wheels - the influence of defect size." Wear 258: 1194-1200.

Kalker, J., J. 1982. "A fast algorithm for the simplified theory of rolling contact." Vehicle System Dynamics 11: 1-13.

Kalker, J., J. 1967. On the Rolling Contact of Two Elastic Bodies in the Presence of Dry Friction. PhD diss., Delft University of Technology.

Karlaftis, M., and K. Sinha. 1997. "Modelling approach for transit rolling-stock deterioration prediction." Journal of Transport Engineering 123(3): 223-228.

Kazopoulo, M., I. Kaysi, and M. A. El Fadel. 2007. "Stated-preference approach towards assessing a vehicle inspection and maintenance program." Transportation Research Part D 12 (5): 358-370.

KEMA-RTC and DHV B.V. 2007. Rail Interoperability and Safety. Transposition of legislation and progress on the field. A study carried out for the European Commission. Brussels.

Kim, H.. 2009. KORAIL human resources and infrastructure system towards "World's best, Korean Railroad”. http://www.jrtr.net/jrtr54/pdf/14-23web.pdf

Lama, A., J. Smirnovs, and J. Naudžuns. 2006. "Road traffic safety in the Baltic States." The Baltic Journal of Road and Bridge Engineering 1(1):63-68. http://www.bjrbe.vgtu.lt/volumes/pdf/ Volume1_Number1_08.pdff

Lautala, P., W. Sproule, and M. Marinov. 2011. Handbook for Rail Higher Education. http://www. ncl.ac.uk/newrail/assets/docs/tunrailhb.pdf

Lin, H. 2010. "An application of fuzzy AHP for evaluating course website quality." Computers Education 54(4): 877-888.

Lingaitis, L. P., and L. Liudvinavičius. 2006. "Electric drives of traction rolling stocks with AC motors." Transport 21(3): 223-229.

Liudvinavičius, L., and L. P. Lingaitis. 2007. "Electrodynamics braking in high-speed rail transport.” Transport 22(3): 178-186.

Liudvinavičius, L., Lingaitis, L.P., S. Dailydka, and V. Jastremskas. 2009. “The aspect of vector control using the asynchronous traction motor in locomotives." Transport 24(4): 318-324.

Liudvinavičius, L., and L. P. Lingaitis. 2010. “New locomotive energy management systems.” Eksploatacja i niezawodność 45(1): 35-41.

Lobb, B. 2006. “Trespassing on the tracks: a review of railway pedestrian safety research.” Journal of Safety Research 37(4): 359-365. 
Lyche, T., and K. Morken. 2008. Spline methods draft. University of Oslo.

McCollister, G. M., and A. Pflaum. 2007. "A model to predict the probability of highway rail crossing accident." In Proc. of the Institution of Mechanical Engineering. Part F- Journal of Rail and Rapid Transit 221(3): 321-329.

Mei, T. X., J.H. Yu, and D. A. Wilson. 2009. "A mechatronic approach for effective wheel slip control in railway traction." In Proceedings of the IMechE, Part F: Journal of Rail and Rapid Transit. 223-295.

Migliardi, C. and C. Nicchiniello. 2012. Report on Euro-Asian Transport Linkages EATL (Euro-Asian Transport Linkages) - Phase II. The United Nations - Report in New York and Geneva.

Myamlin, S., L. P. Lingaitis, S. Dailydka, G. Vaičiūnas, M. Bogdevičius, and G. Bureika. 2015. “Determination of the dynamic characteristics of freight wagons with various bogie." Transport 30(1): 88-92.

Nayal, A., S. P. Gupta, and S. P. Singh. 2006. "Performance analysis of DC motor drive in electric traction with wheel slip control." Journal of Institution of Engineers. India Part EL Electrical Engineering Division 87(2): 55-60.

Niccolini, E., and Y. Berthier. 2005. "Wheel-rail adhesion: laboratory study of "natural" third body role on locomotives wheels and rails." Wear 258: 1172-1178.

Nielsen, J. B., and A. Theiler. 1996. “Tangential contact problem with friction coefficients depending on sliding velocity." Proceedings of the Second Mini Conference on Contact Mechanics and Wear of Rail/Wheel Systems. Budapest. 44-51.

Ohyama, T. 1989. "Some basic studies on the influence of surface contamination on adhesion force between wheel and rail at higher speeds. Q. Rep. Railway Tech. Res. Inst. 30: 127-135.

Ohyama, T., K. Ohno, and S. Nakano. 1989. "Influence of surface contamination on adhesion force between wheel and rail at higher speeds - behavior of adhesion force under the surfaces contaminated with a small amount of liquid paraffin." Journal of JSLE - International Edition 10: 111-114.

Ohyama, T., and H. Maruyama. 1982. "Traction slip at higher rolling speeds: some experiments under dry friction and water lubrication." In Proceedings of the 1st International Conference on Contact Mechanics and Wear of Rail/Wheel Systems. 395-418.

Olejnik, K. 2003. "Critical analysis of the current traffic regulations concerning visibility from the position of a vehicle driver." Quarterly Motor Transport 2: 69-80.

Patir, N., and H. S. Cheng, 1978. "An average flow model for determining effects of three-dimensional roughness on partial hydrodynamic lubrication. Journal of Lubrication Technology 100: $12-17$.

Podofillini, L., E. Zio and J. Vatn, 2006. "Risk-informed optimization of railway tracks inspection and maintenance procedures." Reliability Engineering \& System Safety 91(1): 20-35.

Polach, O. 1999. "A fast wheel-rail forces calculation computer code." Vehicle System Dynamics Supplement 33: 728-739.

Polach, O. 2000. "Influence of locomotive tractive effort on the forces between wheel and rail." In Selected papers from the 20th International Congress of Theoretical and Applied Mechanics. 7-22. Chicago. Also in Vehicle Syst. Dyn. Suppl. 35. 
Polach, O. 2005. "Creep forces in simulations of traction vehicles running on adhesion limit." Wear 258: 992-1000.

Proposal for a Directive of the European Parliament and of the Council on the Interoperability of the Rail System within the European Union (Recast). 2013. Europe Commission. Brussels. 30.1.2013. COM(2013) 30 final. 2013/0015 (COD). 106 p.

Railway Safety Performance in the European Union 2008. European Railway Agency. A Biennial Report from European Railway Agency, 2008. 76 p.

RETRACK. Potential to Eurasian land bridge corridors \& logistics developments along the corridors. 2012. $224 \mathrm{p}$.

Risk Acceptance Criteria for Technical Systems and Operational Procedures. RAC Final Report for European Railway Agency. Report No: 24127328/03. 22 January 2010. Det Norske Veritas. $76 \mathrm{p}$.

RSSB. 2012. Learning from operational Experience. Annual Report 2011/2012. London EC1V 1NY. 69 p.

Saaty, T. L. 2003. "Decision-making with the AHP: Why is the principal eigenvector necessary." European Journal of Operational Research 145(1): 85-91.

Saaty, T. L. 1980. The analytic hierarchy process. New York: McGraw-Hill.

Safety Assurance Guidance RSSB. 2013. Guidance and examples of goods practices in safety assurance in Britain's railway industry.

Savage, I. 2006. "Does public education improve rail-highway crossing safety?" Accident Analysis and Prevention 38(2): 310-316.

Sawicki, P., and J. Zak. 2009. "Technical diagnostic of a fleet of vehicles using rough set theory." European Journal of Operational Research 193(3): 891-903.

Sen, P. C. 1996. Principles of Electric Machines and Power Electronics. New York-Chichester-Brisban-Toronto-Singapore-Weinheim: John Wiley \& Sons.

Sextro, W. 2007. Dynamical Contact Problems with Friction. Heidelberg: Springer.

Shedden, P., R. Scheepers, W. Smith, and A. Ahmad. 2011. "Incorporating a knowledge perspective into security risk assessments." VINE: The Journal of Information \& Knowledge Management Systems 41(2): 152-166.

Silla , A., and V. P. Kallberg. 2012. “The development of railway safety in Finland.” Accident Analysis and Prevention 45: 737-744.

Sivilevičius, H., and L. Maskeliūnaitè. 2010. “The criteria for identifying the quality of passengers' transportation by railway and their ranking using AHP method." Transport 25(4): 368-381.

Stavropoulos, Ch. N, and S. D. Fassois. 2000. "Non-stationary functional series modelling and analysis of hardware reliability series: a comparative study using rail vehicle interfailure times." Reliability Engineering and System Safety 68: 169-183.

Strekopytov, V. V., A. B. Grishchenko, and V. A. Kruchek. 2003. Electric drives of the locomotives. Moscow: Marshrut. 305 p. [In Russian].

Stubbe, J. A. 2008. LabVIEW mini-expert to identify bearing defects automatically. Bruxelles: Department of Applied Mechanics, Universite Libre De Bruxelles, Belgium. http://www.ulb. ac.be/polytech/laborulb/bearing/bearing_miniexpert.pdf. 
Sun, K., and H. Li. 2010. "Scheduling problems with multiple maintenance activities and nonpre-emptive jobs on two identical parallel machines." International Journal of Production Economics 124(1): 151-158.

Szybka J., Z. Broniec, and R. Pilch. 2011. "Forecasting the failure of a thermal pipeline on the basis of risk assessment and exploitation analysis." Esploatacja i Niezawodnosc 4: 5-10.

Tao Tang, Chao Li, and Ru Niu. 2009. Research on Safety Management System for China Railway. Beijing: State Key Laboratory of Rail Traffic Control and Safety, Beijing Jiaotong University,

The Timken Company. Tapered roller bearing damage analysis. 2008.

Tomberger, C., P. Dietmaier, Sextro, W., and K. Six. 2011. "Friction in wheel-rail contact: a model comprising interfacial fluids, surface roughness and temperature." Wear, 27: 2-12.

TREN/R1/350-2008 lot 2. 2010. Situation and perspectives of the rail market. Final Report. University of Leeds.

Tsykhmistro, S., Marinov, M.; Cheptsov, M., and V. Cheklov. 2014. "Euro-Asian co-operation in rail education and research." Transport Problems 9(1): 103-110.

Tsykhmistro, S., and M. Cheptsov. 2014b. "International scientific cooperation for the development of Euro-Asian speed railway connection." In The papers of the 7th International Symposium for Transportation Universities in Europe and Asia.78-85. China: Dalian Jiaotong University.

Tuzik, J. 2014. Data to Decisions: Tools and Technology to Manage Wheel/Rail Interaction. WRI 2014 Heavy Haul: Part 1. September 15, 2014. http://interfacejournal.com/archives/1365

Vaičiūnas, G., and L. P. Lingaitis. 2008. "Investigating the dynamics of passenger rolling stock deterioration." Transport 23(1): 51-54.

Vaičiūnas, G., and L. P. Lingaitis. 2010. "The influence of railroad curves on the wear of lubricated and unlubricated wheel flanges." Eksploatacja i niezawodność 47(3): 40-43.

Wang, L., J. Chu, and J. Wu. 2007. "Selection of optimum maintenance strategies based on a fuzzy analytic hierarchy process." Production Economics 107(51): 151-163.

Wang, W., H. Chen, and M. C. Bell. 2005. "Vehicle breakdown duration modelling." Journal of Transportation and Statistics 8(1): 75-84.

Wang, S., C. Cusano, and T. F. Conry. 1993. "Dynamic model of the torque and heat generation rate in tapered roller bearings under excessive sliding conditions." Tribology Transactions 36(4): 513-552.

Weed, D., and C. Lonsdale. 2011. Review and Analysis of Wheel Impact Load Detector (Wild) and Wheel Removal Data.

Wickens, A. H. 2003. Fundamentals of rail vehicle dynamics: guidance and stability. Lisse: Swets \& Zeitlinger Publishers.

Wiley, R.B., and A. A. Elsaleiby. 2011. "A review of vehicle impact measurement variation.” Technology Digest TD-11-007. Association of American Railroads, Transport technology Center, Inc.

Yagi, T., Y. Oda, H. Ishiduka, and M. Tahara. 2007. "Fatigue design diagram for weld joints on aluminum alloy car body shells." Quarterly Report, Railway Technical Research Institute (Japan) 48(1): 15-21.

Yamaguchi, J. 2006. "Blue skies at Makuhari.” Automotive Engineering International 1: 55-62.

Zhang, W., J. Chen, X. Wu, and X. Jin. 2002. "Wheel/rail adhesion and analysis by using full scale roller rig." Wear 253: 82-88. 
Žygienè, R. 2015. "Research on the dynamic processes of the interaction between the damaged wheels of a railway vehicle and rails." PhD diss. VGTU. 122 p. [In Lithuanian].

Довбня, Н. П., Бондаренко, Л. М. и Коренюк Р. А. 2009. «О величине работы на нагрев подшипников букс локомотивов и вагонов». Проблемь трибологіi 3: 16-17.

Галкин, В., Г. ; Парамзин, В., П., и Четвергов, В., А. 1981. «Надежность тягового подвижного состава». - М.: Транспорт, 1981. 184 с.

Локомотивы и локомотивное хозяйство. Ремонт локомотивов. Обзорная информация. Вып. 2. - М.: Транспорт, 1997. 45 с.

Миронов, А., А. 2008. «Виртуальная модель бесконтактного теплового контроля буксовых узлов подвижного состава." Транспорт Урала 3(18): 59-65.

Миронов, А., А. 2009. “Имитационная модель функционирования аппаратуры теплового контроля буксовых узлов подвижного состава». Транспорт, наука, техника, управление 5: 8-14.

Миронов, А. А., Образцов В. Л., Митюшев, В. С. и Салтыков Д. Н.. 2008. «Тепловой контроль буксовых узлов инфракрасной оптикой». Локомотив 4: 29-32.

Павлюков, А. Э., Миронов, А. А., и Занкович А. В. 2008. «Диагностическая модель бесконтакного теплового конроля букс подвижного состава». Транспорт Урала 3(18): 59-65.

Website links:

http://www.near2-project.eu/en-us/project/description.aspx

http://www.transport-research.info/web/projects/project_details.cfm?id=39274

http://www.era.europa.eu/document-register/documents/risk-acceptance-criteria-for-technicalsystems.pdf

http://ec.europa.eu/transport/rail/legislation/mne_table_en.htm

http://ec.europa.eu/transport/modes/rail/packages/2013_en.htm

http://eur-lex.europa.eu/LexUriServ/LexUriServ.do?uri=COM:2013:0030:FIN:EN:PDF

http://www.railwaygazette.com/nc/news/single-view/view/rolling-stock-acceptance-delays-thecentre- of-debate.html

http://www.everis.com/global/WCLibraryRepository/References/everis_Operacional_In\%20V.3.0.pdf http://ransportproblems.polsl.pl/pl/Archiwum/2014/zeszyt1/2014t9z1_11.pdf

http://www.timken.com/en-us/products/maintdiag/Documents/6347.pdf

http://ec.europa.eu/transport/modes/rail/studies/doc/2010_09_09_study_on_regulatory_options_ on_further_market_opening_in_rail_passenger_transport.pdf

http://ec.europa.eu/transport/modes/rail/events/doc/ppt_presentations/uip_eu_sicherheitskonferenz.pdf http://ec.europa.eu/transport/themes/infrastructure/ten-t-implementation/priority-projects/ doc/2012-2013/ertms-final_en.pdf

http://www.unife.org/uploads/ERR_201206_-_ERTMS_Global_dimensions,_global_challenges.pdf http://www.unife.org/uploads/120425_Press_release_UNIFE_Statistics_on_ERTMS_Deployment.pdf http://iastu-ap.org/ 
http://www.transport-research.info/web/projects/project_details.cfm?id=39274

http://www.eurofound.europa.eu/eiro/studies/tn1109030s/tn1109030s_3.htm http://www.uz.gov.ua/

http://www.ecotransit.org

http://bak.geoprognoz.ru/gp/

http://www.rzd.ru 




\section{Consolidation of technical, safety and human resources in Eurasian railway transport corridors: monograph. Gintautas Bureika, Maria Boile, Christos Pyrgidis, Annie Kortsari, Natalia Ivanova, Tamila Titova, Sergey Tsykhmistro. - Vilnius: Technika, 2016. - 256 p.}

eISBN 978-609-457-978-3

The monograph is based on the outcomes of the considerations that took place within the ambit of the project NEAR ${ }^{2}$ - Network of European-Asian Rail Research Capacities - from 2012 to 2014. The monograph serves to bridge the gaps in knowledge and technology to improve the technical interoperability of railway, rail traffic safety regulations and risk assessment, and rolling stock maintenance system. It also analyses different railway infrastructure and identifies interoperability problems of the Eurasian Railways. This research considers three railway systems (geographical regions): first, the railways of the countries in the European Union; second, the Russian, Ukrainian, and Belarusian railways; and third, the railways of Asian countries. The monograph comprises seven chapters dealing with the particularities of rail safety regulation in different countries, technical aspects of safety and interoperability, infrastructure and signalling, track-side equipment and traffic management, locomotive slip and slide control rolling stock maintenance problems, and staff training \& educational issues of Eurasian Railways. Overall concluding remarks identify future research needs and priorities that support the formulation of a relevant research agenda for the Eurasian land bridge; ascertain the common future research projects concerned with the main topics of the monograph, as well as to the combination of the interests of the Eurasian rail industry and undertakings.

Typesetting and cover design by Rasa Steponavičiūtè

Front cover photos: by Ranameraj "Alexendria bridge over the Chenab River near Gujrat", licensed under CC BY-SA 3.0 (top). By Vaclovas Zabarauskas (bottom).

Volume 24,0 quires

http://doi.org/10.20334/2375-M

Vilnius Gediminas Technical University Press TECHNIKA

Saulètekio al. 11, LT-10223 Vilnius

http://leidykla.vgtu.lt 